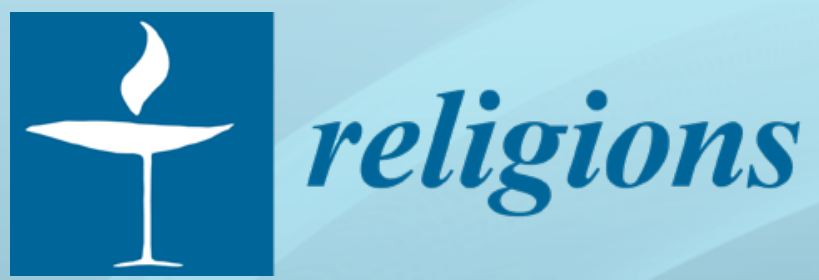

\title{
Religion and Theatrical Drama
}

Edited by

Charles A. Gillespie and Larry D. Bouchard Printed Edition of the Special Issue Published in Religions 
Religion and Theatrical Drama 



\section{Religion and Theatrical Drama}

Editors

Charles A. Gillespie

Larry D. Bouchard

MDPI • Basel $\bullet$ Beijing $\bullet$ Wuhan $\bullet$ Barcelona $\bullet$ Belgrade $\bullet$ Manchester $\bullet$ Tokyo $\bullet$ Cluj $\bullet$ Tianjin

\footnotetext{
MDPI
} 
Editors

$\begin{array}{ll}\text { Charles A. Gillespie } & \text { Larry D. Bouchard } \\ \text { Catholic Studies } & \text { Religious Studies } \\ \text { Sacred Heart University } & \text { University of Virginia } \\ \text { Fairfield, Connecticut } & \text { Charlottesville, Virginia } \\ \text { United States } & \text { United States }\end{array}$

Editorial Office

MDPI

St. Alban-Anlage 66

4052 Basel, Switzerland

This is a reprint of articles from the Special Issue published online in the open access journal Religions (ISSN 2077-1444) (available at: www.mdpi.com/journal/religions/special_issues/Religion_Drama).

For citation purposes, cite each article independently as indicated on the article page online and as indicated below:

LastName, A.A.; LastName, B.B.; LastName, C.C. Article Title. Journal Name Year, Volume Number, Page Range.

ISBN 978-3-0365-2597-6 (Hbk)

ISBN 978-3-0365-2596-9 (PDF)

(C) 2021 by the authors. Articles in this book are Open Access and distributed under the Creative Commons Attribution (CC BY) license, which allows users to download, copy and build upon published articles, as long as the author and publisher are properly credited, which ensures maximum dissemination and a wider impact of our publications.

The book as a whole is distributed by MDPI under the terms and conditions of the Creative Commons license CC BY-NC-ND. 


\section{Contents}

About the Editors $\ldots \ldots \ldots \ldots \ldots \ldots \ldots \ldots \ldots \ldots \ldots \ldots \ldots$

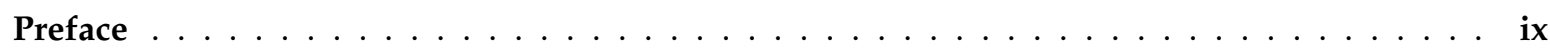

Larry D. Bouchard and Charles A. Gillespie

Religion and Theatrical Drama, an Introduction

Reprinted from: Religions 2021, 12, 257, doi:10.3390/rel12040257 . . . . . . . . . . . . . . . 1

Daniela Cavallaro

Go and Sin No More: The Afterlife as Moral Teaching in Italian Catholic Educational Theatre

Reprinted from: Religions 2019, 10, 517, doi:10.3390/rel10090517 . . . . . . . . . . . . . . 15

Dana Tanner-Kennedy

Gertrude Stein and the Metaphysical Avant-Garde

Reprinted from: Religions 2020, 11, 152, doi:10.3390/rel11040152 . . . . . . . . . . . . . . 33

Michael VanZandt Collins

Toward Witnessing the Other: Syria, Islam and Frans van der Lugt

Reprinted from: Religions 2020, 11, 174, doi:10.3390/rel11040174 . . . . . . . . . . . . . . 47

Charles A. Gillespie

Theodramatic Themes and Showtime in Nassim Soleimanpour's White Rabbit Red Rabbit

Reprinted from: Religions 2020, 11, 499, doi:10.3390/rel11100499 . . . . . . . . . . . . . . 69

David V. Urban

Nora's Ironic Longing for Christlike Love: Self-Sacrifice, Self-Love, and the "Religion of Torvald" in Ibsen's A Doll House

Reprinted from: Religions 2020, 11, 318, doi:10.3390/rel11070318 . . . . . . . . . . . . . . 87

\section{Larry D. Bouchard}

Religion and the Limits of Metatheatre in Our Town and Sunday in the Park with George

Reprinted from: Religions 2020, 11, 94, doi:10.3390/rel11020094 . . . . . . . . . . . . . . . 97

Tom Fish

Bewitching Power: The Virtuosity of Gender in Dekker and Massinger's The Virgin Martyr

Reprinted from: Religions 2019, 10, 629, doi:10.3390/rel10110629 . . . . . . . . . . . . . . 121

\section{Emily Bryan}

"Fantastic Tricks before High Heaven," Measure for Measure and Performing Triads

Reprinted from: Religions 2020, 11, 100, doi:10.3390/rel11020100 . . . . . . . . . . . . . 13

\section{Adam Beyt}

"Beautiful and New": The Logic of Complementarity in Hedwig and the Angry Inch

Reprinted from: Religions 2019, 10, 620, doi:10.3390/rel10110620 



\section{About the Editors}

\section{Charles A. Gillespie}

Charles A. Gillespie is Assistant Professor of Catholic Studies at Sacred Heart University. His research and teaching investigate theology, the arts, and culture with a focus on the Catholic Intellectual Tradition, critical theories of creation and beauty, and theatre and performance studies. He completed his Ph.D. in Religious Studies at the University of Virginia as well as a BAH in Humanities from Villanova University and an MAR in Religion and Literature from the Yale Institute of Sacred Music. A longtime theatre-maker, Charlie trained with the Parapanda Theatre Art Lab in Tanzania and co-founded the interdenominational "liturgical drama" troupe Theatrum Sacrum. He is currently working on his first book, God on Broadway.

\section{Larry D. Bouchard}

Larry D. Bouchard is Professor of Religious Studies at the University of Virginia, in Charlottesville, where he teaches religion and literature, theories of interpretation, religious ethics, and modern theologies of culture. He is a graduate of Texas Christian University (BA, Philosophy, English) and the University of Chicago (Ph.D., Religion and Literature). He is the author of Tragic Method and Tragic Theology: Evil in Contemporary Drama and Religious Thought (Penn State University Press, 1989) and Theater and Integrity: Emptying Selves in Drama, Ethics, and Religion (Northwestern University Press, 2011). He has also published numerous articles and chapters concerning literature and religion, tragedy and theodicy, narrative and ethics, and theology and culture. 



\section{Preface}

We are pleased to offer Religion and Theatrical Drama as a book of essays, which recently appeared as a Special Issue of Religions. This project began as an attempt to reinvigorate dialogue between studies of religion and theatrical drama. We noticed how dramatic terms-such as performativity, character, role, story, and improvisation, to name a few-had become ubiquitous in comparative and critical approaches to the study of religion. Likewise, we noticed how theatrical drama continues to stage theological themes, sacred stories, divine revelations and conundrums, and religious and ethical dilemmas.

These chapters take particular interest in the ways that theatrical drama interacts dialectically with religions. Religious phenomena share family resemblances with theatrical drama as an artistic genre, one that entails the co-presence of actors and audiences in events characterized by their people, actions, scripts, and practices. Theatrical drama illuminates contested contrasts regarding matters such as social construction and givenness, hermeneutics and pragmatic wisdom, integrity and impersonation, repetition and difference, distortion and disclosure. Meanwhile, plays in performance bring together discussions about God and the gods, trustworthy and dangerous traditions, identities and ethics, and the stories that communities choose to celebrate or perhaps refuse to tell or interpret.

Religion and drama have been inherently contested areas for research. When we began this project, we invited interpretive papers working at the intersection between "religious" matters in theatrical drama (widely conceived to include literary-dramatic classics and new plays, music dramas, political theatre, pageantry, devised performances, and more) and studies of religious thought, history, and practice. Inspired by drama's metatheatrical reflexivity (that is, when plays and performances become aware of themselves as works of theatre), we invited reconsiderations of what may be seen as theatrical theologies and dramaturgical methods for the study of religion. Provoked by drama's cosmic conflicts and comic disruptions, we also invited reconsiderations of text and performance, story and spectacle, from varied and new approaches. We realized that theatrical drama generates exciting ways of being engaged by religion-related questions that do not need to be reduced to such binaries as secular/religious, theory/praxis, and drama-as-literature/theatre-as-performance.

We offer our deep thanks to our contributors as well as to our editorial partners at Religions, including too many to name here. But we are especially grateful for the invitation to conduct this project and the patience and support during our discussions with Bingjin Pinky He and Daphne Liao. To borrow the words of Prospero's concluding prayer to the audience from Shakespeare's The Tempest: "With the help of your good hands: gentle breath of yours my sails must fill, or else my project fails, which was to please." We hope you enjoy the essays and the show!

Charles A. Gillespie, Larry D. Bouchard Editors 



\title{
Religion and Theatrical Drama, an Introduction
}

\author{
Larry D. Bouchard ${ }^{1, *}$ and Charles A. Gillespie ${ }^{2, *}$ \\ 1 Department of Religious Studies, University of Virginia, Charlottesville, VA 22904-4126, USA \\ 2 Department of Catholic Studies, Sacred Heart University, Fairfield, CT 06825, USA \\ * Correspondence: $1 \mathrm{db} 4 \mathrm{k} @$ virginia.edu (L.D.B.); gillespiec4@sacredheart.edu (C.A.G.)
}

check for updates

Citation: Bouchard, Larry D., and Charles A. Gillespie. 2021. Religion and Theatrical Drama, an

Introduction. Religions 12: 257.

https:/ / doi.org/10.3390/rel12040257

Received: 22 March 2021

Accepted: 31 March 2021

Published: 7 April 2021

Publisher's Note: MDPI stays neutral with regard to jurisdictional claims in published maps and institutional affiliations.

Copyright: (C) 2021 by the authors. Licensee MDPI, Basel, Switzerland. This article is an open access article distributed under the terms and conditions of the Creative Commons Attribution (CC BY) license (https:// creativecommons.org/licenses/by/ $4.0 /)$.
Often, a lonely light bulb illuminates the edge of a stage outside of working hours. Part safety mechanism against falling in the dark and part theatrical tradition, the "ghost light" keeps the living alive and brightens up the place for any spirits still hoping to practice an old monologue ${ }^{1}$. Stages juxtapose worlds, or fragments of worlds. The ghost light, then, would illuminate juxtaposed worlds, of the living and of the possibly otherwise. In some ways, this Special Issue of Religions takes theatrical juxtaposition as its premise. We invited papers working at intersections between studies of religious history, thought, and practice and studies of theatrical drama.

We began this project long before a global pandemic caused commercial and amateur theaters to go dark for a long time. That sentence might have just as readily addressed the flowering of digital scholarship or the many live-streamed religious practices that have developed as a result of COVID-19. We intended this introductory note to appear at the start of the project and so composed it then. Thanks to a number of reasons, our introduction now appears at the project's conclusion, but we decided only to make a few small additions in lieu of a new version. Reading, writing, and thinking about theatrical drama during and after a time of hiatus will juxtapose our current world with many others. In many ways, a time of pause might be the best time to reconsider the exchange between religion and drama in hopes of new approaches still to come.

Like the best staged stories, complications and conflicts emerge almost instantly. Religion and drama are inherently contested areas for research, and we believe that scholarly approaches in both areas have fragmented in analogous ways-ways we see as mutually beneficial. Into such an "empty space" between the fragments, as Peter Brook might regard our juxtaposition ${ }^{2}$, we hope to stage crisscross illuminations (Brook 1968). Not so much to resolve antagonisms (antagonisms that often seem "natural" and "common sense") but to encourage new conversations where potential conflicts are viewed differently, sometimes dialectically and even companionably, giving rise to new and surprising knowledge. What discoveries could be unveiled anew in readings of dramas and religions in the theatrical ghost light?

Studies of theatrical drama and studies of religion share a number of hermeneutical concerns. What phenomena provide the objects of study? Will they be embodied persons, practices, institutions, ancient traditions, new movements, beliefs and theories, material cultures, texts, archives? Theatrical drama demands all the familiar practices necessary for interpreting literature: close reading, philological analysis, and engagement with questions of form, genre, style, intent, and authority. At the same time, however, interpretations of theatrical drama must remain aware of drama's orientation toward an end in theatrical realization in social space and time. Where and how do the contributions of actors, design-

\footnotetext{
1 See "Ghost Light" in (Fisher 2015).

2 "I can take any empty space and call it a bare stage" (Brook 1968, p. 9). David Wiles complicates Brook's famous metaphor, observing how all spaces are particularly contextualized, never "empty" as such (Wiles 1997, pp. 3-4). We suggest that theatrical drama negotiates emptiness, demarcations, and crisscross movements.
} 
ers, producers, and audience reception impact theoretical readings and the appropriation of theatrical categories? ${ }^{3}$

Problems in religious studies methods can be said to "rhyme" with the genre trouble faced by studies of theatrical drama. It is well known that the field of religious studies includes comparative and critical approaches often guided by functional definitions and methods, including ironic awareness of the near impossibility of defining religion satisfactorily as a generic subject matter while proceeding as if it could be. Yet, the field of religious studies also incorporates scholarly disciplines practiced more or less within traditions. Such scholars interpret aspects of belief, affect, thought, and practice often while interpreting history, society, culture, and nature in ways informed by traditionary and constructive perspectives (from Mahayana Buddhism, Roman Catholicism, North American indigenous traditions, Ethical Humanism, and traditions within traditions, e.g., Hasidic Judaism, Sufi Mysticism, Kiowa Sun Dance ceremonies). So-called critical and confessional ways of studying religion are frequently regarded as antagonistic, especially if certain traditions seem implicitly hegemonic in given academic spheres. However, such ways of putting things prove, on countless occasions, to be a false binary. Drama in the theater may well help us explore and reconsider how to move interpretations beyond such binary occasions.

Conversations between religion and theatrical drama often stall, mired in putatively commonsensical origin stories and disciplinary antagonisms. Consider how religiouscultural ritual and meaning making can be read as performance. As with the contests of the Olympian gods staged at Delphi, the emotive ghosts of Japanese Noh theater, reenactments of Christ's passion at Oberammergau, Purim plays, Indian classical drama-in these, theater and religion seem to have converged. Moreover, given the cultural or historical distance now separating us from them, such convergences can now appear anew and differently with shifting interpretive paradigms. For instance, do Euripides' Bacchae sing praises for Dionysus as an act of worship, to reify civic values and duties by displaying the dangers of unchecked bacchanalia, or to lament the conflicted power structures of family, tribe, gender, or even substance abuse, not to mention the complications of "fate" or random contingency? It is by no means clear that different disciplinary approaches to religion and theatrical drama must place these meanings into zero-sum competition; yet, that can be what happens. One finds dramatic literatures studied alongside other narrative and lyric forms in the field of religion and literature with minimal attention to performance or performativity. Theatrical events are grouped alongside other ritual activities, with minimal attention to theological or atheological ramifications. Theatrical theologies and dramaturgical approaches to religion may borrow drama's vocabulary without attending to distinctive ways in which religious meanings are constructed and interpreted through the arts of theater and drama.

Yet, our name for this hybrid art form, "theatrical drama", bears traces of its own binary antagonisms. While drama and theater are often interchangeable, overlapping terms, "drama" can connote a kind of literature-plays, which represent, through dialogue, characters involved in temporally concentrated ("dramatic", "comic", "tragic") actionstogether with the practices (acting, directing, etc.) of interpreting plays in performance. Whereas "theater" often suggests the arts of making performances to be seen and heard (what Aristotle called spectacle, opsis), and "theater" gives much attention to performanceaudience-spatial relationships and to the business (including economic) of sustaining this performing art. One locus of antagonism has been the play script. The study of dramatic literature can be regarded as marginal to "actual" theatrical performance and, of course, vice versa. We are reminded that to perform Shakespeare's Scottish play-in the round, in modern dress (or cross dress), crossing back and forth from stage (or no stage) into an audience, indoors or outdoors, in sun or starlight or in rain, a la Stanislavski's methods

\footnotetext{
For the influence of such questions on twentieth-century Christian thought, see (Gillespie 2019).
} 
or Brecht's-we eventually need the thane of Cawdor and, at least some of, the story and script of Macbeth ${ }^{4}$.

Arguments between drama-as-literature and theater-as-living performance have been fruitful, yet also deadly if cast as incommensurable oppositions. In certain ways, drama/theater binaries resemble those in religious studies, as when comparative and critical methodologies seek to keep one at an existential distance from the "actual" religious perspectives and practices studied or when tradition-informed scholarship proceeds as if comparative and critical perspectives on religion were irrelevant. We can also sense resemblance in comparable charges of bias. The field of theater studies often exposes in culture, including religion, a pervasive "anti-theatrical bias", having to do with threatened authenticity, a famous example being how "hypocrisy" comes from a Greek word for stage acting ${ }^{5}$. Arguably, there is an analogous "anti-religious bias" that regards any trace of cultural, institutional, "traditional", or rarified religiosity as inherently self-and-other blinding and oppressive, also threatening some sense of credibility and authenticity. That the two biases can conjoin is seen in the early Protestant charge against the Latin Mass as "hocus pocus" - perhaps a parody of hoc est enim corpus meum - as if it were a theatrical magic show, or reflected in contemporary concerns about the "entertainment production value" of some mega-church worship services.

Perhaps it is inevitable that when one brings estranged fields into closer conversation, the terms of engagement will still pre-condition how the available resources are deployed, which has been the case with terms such as "ritual", "spirituality", "drama", and "performance". As it happens, when disciplinary innovators employ such terms, engagement with theatrical drama may be precluded, as if a vestige of an earlier, naïve period of study. One may hear, for instance, that performance studies is not theater studies; spirituality studies is not the study of religious institutions. Consider Catherine Bell's Ritual Theory, Ritual Practice (Bell 2009), which has shaped how the approach of ritual studies to religion has redefined itself along Foucauldian and constructivist lines. Identifying a hermeneutical thoughtaction dichotomy in Clifford Geertz, for whom symbols and rituals in religious cultures effect a synthesis of "ethos" and "world view", Bell observes how Geertz inscribes a depth semantics-that is, reading ritual "like a text" - which cannot take ritual seriously as action. When symbol and ritual are treated as expressions of communal meaning and understanding (verstehen), they become inherently translatable into the consoling, stabilizing terms (indeed, the ethos and world view) of the anthropologist qua anthropologist. Something similar might be said of Victor Turner, for whom-during the liminal phase of a rite of passage - the meaningful lore of elders becomes newly available to initiates. Bell's theorem attends to the power play of ritualizing, how the "ritualizers" (e.g., priests and prefects) are in effect establishing their positions vis a vis those ritualized. Power consolidation is the deliberately obscured (hocus pocus) but crucial point of ritual activity.

For Bell, however, something such as theatrical drama - even if it were both meaningmaking and power-making, hermeneutical and political —would not be of great theoretical concern. Bell much enjoyed theater ${ }^{6}$, but her view of ritual is not at base complicated by particular meanings and dramas as such. Our point is not, however, that Bell was as reductive to power play as Geertz may have been reductive to stable meanings or that power versus meaning is no less a binary than action versus thought. Our point is not even (or only) that power and meaning might be brought together more dialectically. Rather, to the extent that Bell is correct - that a group's ritualizers consolidate power and resistance and that consolidation happens in motivated and contextualized actions both seen and not seen (that is, occulted or hidden) — then ritualizing is both dramatic and theatrical. Far from being a supplementary augmentation to how ritual should be studied, actual dramas and theatrical performances can and should be brought into interrogative relationships

\footnotetext{
See especially "Text and Performance" in (Hornby [1977] 1995, pp. 92-109).

See (Barish 1981; Freeman 2017).

See Diane Jonte-Pace's Foreword to Bell 2009 where she describes a play Bell wrote for friends, a "Millennium Masque" (Bell 2009, p. x).
} 
with studies of ritual—politically and hermeneutically, in terms of particular meanings and particular powers.

Earlier projects in anthropology and sociology, such as those by Kenneth Burke, Victor and Edith Turner, and Irving Goffman, did deploy dramaturgical analogies for social life. This trajectory, operating across literary studies, anthropology, and sociology, later settled into something entirely new called performance studies. Theater practitioner and theorist Richard Schechner identified many "points of contact" between theater studies and anthropological research, which would be "necessary if we are ever to comprehend performance interculturally and theoretically" (Schechner 1985, pp. 21-22). To learn "performance knowledge" requires moving beyond the canons of playwrights and theorists that reduce the performance event into, as he would put it, simply staging a play. Schechner embraced performance knowledge head on, developing and deploying his ideas through the work of The Performance Group. Their Dionysius in '69 performed a version of the Bacchae as an immersive event with ritual actions, actor improvisations, and a concluding procession out into the streets of New York.

Schechner's movement away from playwrights and techniques problematizes theatrical drama's ties to literary cultures, for drama does tend to sacralize the play as verbal script. "In the West, the active sense of script was forgotten ... and the doings of a particular production became the way to present a drama in a new way. Thus, the script no longer functioned as a code from transmitting action through time; instead the doings of each production became the code for re-presenting the words-of-the-drama" (Schechner 1977, p. 38) $)^{7}$. Performance encompasses the entirety of a theatrical dramatic event, including its audience. Indeed, performance interfaces with other aspects of social life and need not be theatrical at all. "Just as drama may be thought of as a specialized kind of script, so theatre can be considered a specialized kind of performance. Thus another model can be generated, one of oppositional pairs: Drama/Script-Theatre/Performance. Cultures which emphasize the dyad drama-script deemphasize theatre-performance; and vice-versa" (Schechner 1977, p. 39). Schechner implies that when scholars (of drama or of religion) place interpretive weight on "Drama/Script", they limit theatrical drama to its semantic power, derived from the canonical dramatist whose scriptural words matter far more than the ephemeral, contingent actions of a theater ensemble or the contextualized ritual actions of a religious community.

The fusion of performance and ritual studies has rightly encouraged us to contend with the reign of legitimizing logoi over theatrical drama and ritual practice. However, in Dionysus in '69, The Performance Group actually did use nearly half of Euripides (in William Arrowsmith's fine translation) and debated which player improvisations were working and which were not as the performance developed and stabilized over time and attracted a following of knowledgeable audiences. Not only was the "show" theatrical drama, but its stretched yet strong dialectic of performance and story (especially its analogy to political gods of mob violence-“'If Nixon in '68, why not Dionysus in '69?") ${ }^{8}$ —continues to contribute to performance knowledge and ritual theory.

Even so, when scholars of the performance paradigm put their interest into empirical methods of both power and semantic analysis, they may still risk disregarding theater's and ritual's perennial interest in human experiences of the unseen or invisible. Consider how Donalee Dox's Reckoning with the Spirit in the Paradigm of Performance articulates the need for performance studies to find approaches that are genuinely attentive to a practitioner's reports of spiritual experience. She draws on cognate methods-from religious studies takes on spirituality to neuroscience and psychology of religion, as well as cultural theoryto question and learn from "what cannot be seen in vernacular spiritual practices but is (for practitioners) nonetheless present" (Dox 2016, p. 148). These answers cannot be translated into the empirical or materialist terms prized by the performance paradigm, and they

\footnotetext{
The italics in this quotation are ours.

See (The Performance Group 1970; Shephard 1991).
} 
retain their spiritual sense. Rather than abandon the scholar's task of rigorous analysis and simply "affirm" spiritual experience as ineffably personal, Dox argues for thinkers to integrate mind-body-spirit and community to see performance as a "permeable boundary between people's sense of an inner, spiritual life and the bodies acting in the materiality of culture" (Dox 2016, p. 60). Performance now becomes a porous boundary between the visible and the invisible, public exteriority and inner life, shared material cultures and personally meaningful spiritual experiences. Dox attends to unsung spiritual knowledge in "Western vernacular spiritualties", phenomena she finds too quickly dismissed away as commercialized orientalism or trite therapeutic play.

Indeed, the dominating discourse of performance and performativity in religious studies (e.g., Schechner, Bell) undervalues dramatic materials, especially texts and scripts, and the religious meanings, theologies, and ideologies those dramatic materials construct, complicate, and disclose. Dox's and others' work within the materiality of performance and spirituality opens up epistemological, scientific, and cultural questions apart from (predominantly Christian) theological assumptions; yet, they also proceed to foreclose other lines of theological and religious inquiry that might benefit from their own reckoning with performance. For instance, Dox writes, "The ontological status of spirituality is outside the scope of this book" (Dox 2016, p. 17). Perhaps so, perhaps not? To juxtapose fields of study under any heading also means wagering that they may continue to illuminate each other, especially in consideration of their forms, meanings, effects, and occasions. As actors told to "find their light" know very well, any illumination of some part of the stage will also cast shadows onto others. A return to consider religion and theatrical drama does not mean we intend to disregard theater's social embodiment or the elitism that reduces religious studies to the analysis of institutional theologies.

Rather, our goal is to expand the playing space we find between religion and theatrical drama to include literary texts, philosophies, histories, normative theologies, ethics, and comparative analyses alongside work with ritual, performance, and spirituality.

Already, for instance, we have used the word "practice" in reference to both religion and theatrical drama; and it is easily observed that both fields involve narratives and dramas (stories and scripts in various senses) and spectacles (activities arranged to be seen and heard). As treated above, ritual has probably been the most commonplace of Schechner's "points of contact" between religion and drama, though more of the side of "theater" and performance studies. What would it mean to apply these lessons to the interpretation of dramatic texts and theatrical art? We invited practical and theoretical studies of religion with theatrical drama (plays, performances) whose occasions would, if not overcome such binaries, see them more as dialectical relationships (in Paul Ricoeur's sense of simultaneous continuity and discontinuity). One way of doing so, in some of our own work on theatrical drama, has been to notice "metatheater" (generally, a work of theater becoming aware of itself as theater, but not confined to "plays-within plays" or actors who overtly break "fourth walls"). Metatheater is a phenomenon noticeable not only in performance, but also in the language of plays and in action being dramatized. ${ }^{9}$ Metatheater foregrounds the ritual or conventional structures at play in theatrical drama and religious practices. The pre-show invitation commandment to "turn off your electronic devices" is, in a strict sense, performative speech that initiates the audience into their necessary participation in the performance, styled as silent observer, on-stage volunteer, or some combination depending on the choices of the playwright and production.

So, let us return to Macbeth, whose actions in part turn on performing, appearing, and not appearing to others to be a legitimate king, and to its metatheatrical beginning:

\footnotetext{
9 A locus classicus is (Abel 1963). In our work, we distinguish three, sometimes overlapping, metatheatrical occasions: 1, when plays directly refer to themselves (e.g., the Stage Manager in Wilder's Our Town); 2, when plays or staged performances occur within the action represented in the play (e.g., the Mousetrap in Hamlet, the "For the Love of Venus" scenes in Suzan-Lori Parks' Venus); and 3, when theater-like dimensions in life are so emphasized as to refer indirectly to the play or theatrical environment (e.g., Hamlet's reaction to Gertrude's and Claudius's presiding at court, in his "suits of woe" soliloquy; when soliloquies are played to address the actual audience, they could count as metatheater-1).
} 
a twelve-line scene with three witches. ${ }^{10}$ Ostensibly, the witches have gathered to plot the fate of Macbeth, but their language implies the contingencies of encounter- "When shall we three meet again"—and of setting-"In thunder, lightning, or in rain" and "Where the place? Upon the heath." Everything about them is "performative", in that their words effect what they mean (and as witches they could presumably effectuate the weather), through spectacles intended for Macbeth and also for us. When Macbeth is staged, words and actions within the story will prompt decisions about everything we, the audience, will encounter in the mise-en-scène of a given production, which, in any case, will have to contend somehow with this "fair" and "foul" world's "fog and filthy air". Macbeth is now so established in English discourse and so referential to its production history that the play seems to anticipate the future of its language. In its time, "when the hurlyburly's done" likely referred to tumult and insurrection. In 1984, it referred to the tumult of frantic living and acting in David Rabe's play about actors, Hurlyburly; however, it is easy to imagine this meaning being implicit in 1606. For the witches' words are also addressed to the audience (will the witches reappear?), to the frantic business of the stage (at a theater or at court, where Macbeth may have been early performed), and to vague yet intense human contexts: does not every "meeting" anticipate many futures?

Does the scene illuminate religion and does religion illuminate the scene? One can ponder this question variously: in terms of appearance and reality, visibility and invisibility, seeming and being, theologically and ethically. These were issues of existential import to Elizabethans and Jacobeans trying to negotiate inner religious convictions and exterior religious appearances against the dangerous winds of Catholic heritage and Protestantpolitical reform. Theatrical drama places its audiences face-to-face with face-to-face and mask-to-mask encounters. Sarah Beckwith observes that when the King, Duncan, tells Malcom that "There's no art/To find the mind's construction in the face" - in reference to a former thane of Cawdor whose treason he could not forgive and saying this just before he greets his new thane, Macbeth-he ironically speaks a theme pervasive in Shakespeare (Beckwith 2011, pp. 9, 16-23). How can we see (before, beside, or behind the face) "that within which passes show" (Hamlet, I.2), namely the sincerity, authenticity, integrity, or lack thereof of an embodied human being? Theatrical drama is especially situated to probe such a question, in that each time an actor steps forth "in character", the construction of mind and spiritual (geistig, geistlich) presence is interrogated. Theatrical acting recapitulates the problematic play of personal, ethical, and religious presence in life; and dramatic art perennially re-represents the problem, as in Duncan's statement (all the more ironic because he will fatally fail to construe Macbeth.) What theological, political, and fictional persons do theatrical masks and dramatic faces reveal and conceal?

Or, one could ponder the Jacobean contexts of witch references. Are "witches", actual and/or imagined, part of religious discourse in and around London, where theaters and pulpits to some extent competed for the same audiences? Are such references uncritically reflective of ideological distortion in English political and religious discourse? Or are the references critically reflective? Is their abiding presence in the play covertly but noticeably commenting on a putative failure of religion in England to exorcize or subdue belief in them? And, or, are they theatrical substitutes for theological meanings that could not then be openly dramatized; are they, for instance, providential agents of divine or demonic judgment-or not? ${ }^{11}$ And do they reflect not only historical lore of the occult and the demonic but also realities-be they social, psychological, political, cultural-structural, linguistic, even "natural" or "divine" — that any age must contend with, albeit in particular, ever changing ways?

The occult themes in Macbeth, moreover, confer something else to theater history, in the allure of its purported curse. Actors dread the cavalier mention of the title character's name as a sign of bad luck or worse. That the Scottish play has produced many euphemisms-

\footnotetext{
10 While some once questioned the Shakespearean authorship of this first scene, few would today; although, other witch scenes or lines (III.5, parts of IV.I) are generally considered interpolations. See Sandra Clark and Pamela Mason's "Introduction" and "Appendix 1" to (Shakespeare 2015).

11 Such questions are explored, with respect to several of Shakespeare's plays, in (Knapp 2002; Greenblatt 1988, 1993, 2001, 2004).
} 
Mackers, MacB, Macbiddy — displays a quasi-ritual work around its weird and dangerous subject matter. The thane's name should, perhaps, never be uttered except when explicitly required by and for the performance of Shakespeare's script. The theater-makers' intentions and community would always matter for the power of this name, a power that emerges epiphenomenally between the text and its interpretation. Theatrical dramas, similar to religions, live within what Hans-Georg Gadamer called histories of interpretive effects; that is, a play's effects "on" or "in" history are real through interpretive responses to responses, including performance histories ${ }^{12}$. The name of an ancient Scottish king starts to patrol a sacred precinct. Why are we so intrigued by these stage witches, plotted fates, and special names? Linguistic markers carry existential weight; theatrical drama complements, unsettles, and recreates the markers and the weight.

Such a mode of history as interpretive and performative is also evident when religionists and dramatists acknowledge fluidity among original documents, events, and discoveries. Quests for an authentic inscription-documentary hypotheses for the composition of the Hebrew Bible, archeological searches for some ancient papyrus bearing the autograph of Saul/Paul of Tarsus, or for the earliest recitations of the Qur'an, or an explanation of the angel Moroni's gift of the Book of Mormon to Joseph Smith-such quests mirror the hermeneutic difficulties that bear on theorizing theatrical drama. The inherited script for Macbeth reports a collaborative effort formed by the necessities of seventeenth-century stage technologies, marketability, political intrigue, the talents of available actors, not to mention four centuries of editorial decisions. Yes, it is the thematic calamity of the drama's story - the depth of the king's betrayal — that conjures up a history of theatrical realization; yet, the thematic calamity is inseparable from that ongoing hermeneutic-theatrical praxis, which constitutes Macbeth/Macbiddy.

Through such praxis, the ghost of Banquo now haunts playhouses rather than Scottish castles. There must be some consequential similarities and differences between the ideation of Macbeth's violence and its mimetic realization. Theatrical action, which has its own contingencies and dangers (falling flats, dropped lines, breaking a leg while "breaking a leg"), both establishes and crosses permeable boundaries between the fictional stories told and the lived histories of storytellers and audiences. Theatrical drama raises the stakes for interpreting what sorts of tragedies and curses count as real or which witches and superstitions should be avoided. A choice to read or perform Macbeth wagers on this story's continuing importance and its aesthetic merit even as interpretive decisions must calculate for any moral dangers or argumentative distortions.

So, should the hermeneutic and critical juxtaposition of religion and theatrical drama constitute a distinct subfield with its own developing methodologies? This questioncomplicated, for instance, by connotations of ownership and approached obliquely rather than directly-helps to organize many of the concerns at work in this Special Issue of Religions. It is attentive to two marginalized discourses: religion at work in the study of theatrical drama and theatrical drama at work in the study of religion. We sought articles that would help many fields to overcome the rhetorical traps laid by organizing heuristics such as "religion" and "theatrical drama". In even shorter words, we remained hermeneutically and critically interested, but not exclusively so, in plays-in-performance and in religious meanings and emotions.

As with Antonin Artaud's phrase "theatre and its double", the essays in this Special Issue not only complicate binaries in religion and theatrical drama, but also develop them toward new understandings (Artaud 1958). Theatrical drama holds its magic mirror up to

12 Hans-Georg Gadamer theorizes interpretation as an encounter aimed toward an understanding already imbedded within traditions that include the interpreter's own forestructures or prejudices (that is, pre-understandings). Neither interpreters nor the objects of interpretation can step outside of history and its affects/effects. "Consciousness of being affected by history (wirkungsgeschichtliches Bewußtsein) is primarily consciousness of the hermeneutical situation" (Gadamer 1989, p. 301, emphasis original). For more on the relationship between Gadamer's hermeneutics and the performing or playing of theatrical drama, see the major section on "Play as the Clue to Ontological Explanation" (Gadamer 1989, p. 101ff). 
the invisible, even "metaphysical", as well as to overt and visible dimensions of social life. ${ }^{13}$ Consider, for instance, how Schleiermacher's "intuition and feeling" of the infinite universe (Schleiermacher [1799] 1996, pp. 22-23) or the unspeakability of a silent scream (Bertolt Brecht's gestus for his character Mother Courage $)^{14}$ might be expressed or suppressed by theatrical characters. Thornton Wilder's Our Town displays emotional responses to realities that are better expressed subjunctively, through the temporality of the stage. The last act permits an encounter with valued relationality, developed in depth and richness over a lifetime, compressed into a single overwhelming, disturbing moment, perhaps sub specie aeternitatis.

The problem of invisible reality returns, with differences, when we consider the repetitions of theatrical events that are inherently ephemeral. Whose version of script (or for that matter scripture) guides truth into view? Do conflicting interpretations lead to some combination of destruction, deconstruction, and revelation? Should we remain comfortably at home in our disciplinary languages or venture toward foreign lands with only books as our guide? Tony Kushner's religiously saturated ruminations on communication and transcendence provide theatrical models to question the mutual legibility of interreligious dialogue. Can religious or dramatic tourists ever speak the same language? Consider how Kushner's at least thrice revised, twice published Homebody/Kabul complicates assumptions about textual authority as a plot device and as a phenomenon in itself. Performativity trades on repetition, difference, and citation. Do scholarly or theoretical interpretations of theatrical drama differ significantly from the interpretive re-readings of playwrights, actors, and directors? Homebody/Kabul asks rather directly, through its story and its auto-redaction history, about the dangers of poetic words unmoored from community, place, and history.

Despite the figurative and sometimes physical dangers, theatrical border crossings disclose the cultural inflection of religious meanings. However, the norms that distinguish theatrical drama worthy of serious engagement from silly entertainments remain unwritten. That is, theatrical drama consistently challenges the genre rules that govern the traditions of scholarly interpretation. By construing religion and theatrical drama so broadly, we invited considerations of any and all instances of theatrical drama: from literary dramatic classics and new plays to music dramas and commercial musical theater, political theater, liturgical pageantry, and devised and experimental dramas. Religious and theatrical phenomena can be co-conspiratorial. The sound of theatrical drama permeates religious events with great frequency: Wagner's Bridal Chorus from the music drama Lohengrin or "Sunrise, Sunset" from Fiddler on the Roof at weddings. Genre shapes (and revises) audience expectations akin to religious intentionality. When Tevye addresses an auditorium full of paying customers, while speaking directly to "you" — that is, the God who made "many poor people" — does the audience implicitly play a divine role? What separates the theatrical drama of a religious ritual from commercial spectacle? Both exemplify "Tradition".

The materiality of strange bodies-and remember, the medium of theatrical drama is enfleshed, speaking, moving persons alongside other such persons-preoccupies the gaze of anthropologists of religion. Theatrical drama can become a surgical theater for the intellectual dissection of religious ideas. When Suzan-Lori Parks' play Venus begins with

13 For Artaud, every object “on stage" (i.e., in performance space)—from players to props, stillness to gestures, silences to musical sounds, declamatory speeches to inarticulate cries-becomes a sign in a larger signifying event. All things on stage become double; they are both themselves and their signing, which in turn is "metaphysically" revealing. "[B]etween life and theater there will be no distinct division, but instead a continuity" (Artaud 1958, p. 126). In characterizing this depth-revealing sensibility as "mystical", "alchemical", "magic", and "sorcery", Artaud identified the performative, efficacious power of what he called works of total theatre to disclose or materialize meanings in ways that remain irreducible to the theatrical event's ingredient parts. Artaud thus distinguished "revelations" in theatrical performance from mimesis as mere ornamentation and dissembling.

14 Gestus, here, signals the range of representational and disruptive acting techniques aimed at undermining the audience's merely passive empathy. In Brechtian jargon, Mother Courage screams in slow motion and without sound so to employ one of Brecht's Verfremdungseffekte (distancing or alienation effects, which make the familiar strange). The audience simultaneously sits with the horror of the death of a child and the virtuosity of an actress who is not, in reality, that child's mother. See the vivid description and illustration of Helene Weigel's performance of the "silent scream" from the Berliner Ensemble's 1951 production of Mother Courage and Her Children in (Rouse 2007, pp. 303-4). See also "Alienation Effects in Chinese Acting" (Brecht [1957] 1964, pp. 91-99, especially, pp. 94-96) and "A Short Organum on for the Theatre" (Brecht [1957] 1964, pp. 179-205, especially paragraph 47 , p. 193). 
an actress donning the bodysuit of the Venus Hottentot, the audience confronts questions of bodily authenticity and racialization (Bouchard 2011, pp. 200-6) ${ }^{15}$. Goddess and freak, lover and specimen, the spectacle of the Venus Hottentot ritualizes dis- and re-embodiment. Theatrical drama loans flesh to the interpretations of narrative, but in what ways has that incarnational model presumed a European, Christian, and male gaze? The Brechtian flavor of Parks' play alienates its audience from easy catharsis. Feelings of heartbreak and empathy will be ruptured by laughter and singing; the moral comfort of historical and cultural distance from the anthropological abuses on display will be subverted through contemporary idiom and direct address. Theatrical drama risks, but rarely realizes, the literal touch of bodily presence in a political space where comfortable abstraction must yield directly to social commentary. At the very least, live performance invites the proto-political speech needed to negotiate a shuffle towards the exits.

Far from reducing theatrical drama's aesthetics to moralizing or ethical pedagogy, religious reflection finds an explanatory ally in drama's structures and stories. Consider the emergence of theatrical theologies and dramaturgical methods for studying the Christian tradition. Some deploy theatrical analogies to frame Christian theology as a task of corporate and community interpretation. Theologian Kevin J. Vanhoozer finds drama to be the core of doctrinal debate to find communities with "faith speaking understanding."16 Theatrical language clarifies the telos of scriptural interpretation in liturgical and communal living. Theological dramatic theorists such as Tom Driver have found within the history of theatrical drama and its ritualizing a mode for modernity to ask "religious" questions with irony ${ }^{17}$. Indeed, theatrical drama has long reinvigorated care for bodies and affect as they inform religious reflection. Sarah Beckwith finds theological development in the transportable, multi-bodied, and streetwise Jesus of the medieval Corpus Christi plays as it transfigures and transports the meanings of sacramental performances usually restricted to a church space. The liturgical bread-body plays its role differently in dialogue with the bodies of Christ of the processional drama (Beckwith 2001). New theological questions surface in the pageant's wake. Broadway theater producers continue to make money from devout audiences hungry for scriptural and religious themes. Commercial plays can be interpreted as serving both God and mammon, nuancing and constructing theological meaning through scriptural interpretations. ${ }^{18}$

Such interpretations, moreover, might even venture into the abstract realms of theology. Conversely, the language of theatrical drama might wander into the pages of the churchly (a la Karl Barth's kirchlich) theories on God, transcendence, and ritual. Recent turns to a "theatrical theology" (Vander Lugt and Hart 2014; Craigo-Snell 2014) follow the large footprints of Hans Urs von Balthasar's five-volume fusion of the European dramatic tradition and Christian systematic theology in Theo-Drama (von Balthasar 1988, 1990, $1992,1994,1998)$. If religion promises to codify and represent for our consideration in the "mirror held up to nature" those feelings and beliefs that make existence meaningful, then

15 See also (Bouchard 2011, pp. 200-6). These comments on Venus, however, are shared by Gillespie and Bouchard.

16 "Doctrine is dramatic, then, because it concerns the church's efforts to perform it, to speak and show its understanding of what God is doing in Christ to renew creation" (Vanhoozer 2014, p. 27). Vanhoozer's title, Faith Speaking Understanding, alludes both to Anselm's formula-fides quaerens intellectum, faith seeking understanding-and to Vanhoozer's application of the theatrical analogy to the importance of doctrinal debate for the life of the Christian church. See also (Vanhoozer 2005).

17 Tom F. Driver narrates the "modern spirit" of theatrical drama by way of a combination of "historicism, the quest for reality turning into query, and the pervasive use of romantic irony" (Driver 1970, p. xxviii). His history and critique of playwrights, plays, and major productions stretches from the romanticist aesthetics of the early nineteenth century to the emergence of the avant-garde "Happenings" in the 1960s. See the discussion of ironic tragicomedy, Beckett, Artaud, and the "happenings" (Driver 1970, pp. 386-90). Driver's history stops at the rift between drama-script and theater-performance we have already associated with Richard Schechner. The latter's Dionysus in '69, while arguably remaining a play, seemed to process out of the bounds of theatrical drama toward a ritual that constituted another genre. Its concluding parade from its playing space into NYC's Wooster Street included the audience in a ritual action beyond the scope of theater history as such. Driver himself turns to performance in Driver 1998. With reference to plays, anthropologists, theologians, ritual theorists, and his own practical work, he construes ritual transformation as essentially connected to preserving freedom. Ritual becomes a process of liberation, different from art, through "work done playfully" (Driver 1998, p. 99). The analysis of ritual funds Driver's constructive argument for the liberating work of Christian sacraments and his negative assessment of churches that block ritual's liberating efficacy (Driver 1998, pp. 195-222).

18 Bial (2015) recounts the odd preponderance of commercial plays with biblical themes in U.S. theater history. 
theatrical drama can clarify these emotional stakes and share stories of value and identity that are necessarily received and performed by material, embodied persons of spirit, difference, and freedom.

Theatrical theologians could seek to recover and theorize what Walter Benjamin calls "aura", in a post-print age characterized by its screen-time (Benjamin 1969). ${ }^{19}$ However, theological interventions in theatrical drama might cause religious reflection to obfuscate yet again its still-habitual reliance on bourgeois values and aesthetics as if they were part of theatrical drama's genre conventions. Theatrical drama can store, incubate, and reignite oppressive histories just as easily as it critically retrieves and challenges them. The racist heritage of the minstrel show informs the politics of the American musical, from Oklahoma! to Hamilton. In response to this danger, for example, religionists with theoretical interest in theatrical drama must account for what José Esteban Muñoz has called the "burden of liveness" that stage conventions have placed on minoritized performers (Muñoz 1999) ${ }^{20}$. Do theoretical juxtapositions of institutional theologies with theatrical drama emancipate possibilities for the study of religions or simply mask old prejudices with new makeup and costumes?

At this concluding point, we might reconsider one of the oldest Western theorists of drama and performance, Aristotle of all people. What classicist James Redfield and literary-ethical theorist Martha Nussbaum have noticed is that Greek narrative epic and tragic drama, both of which were sung in performance, were on Aristotle's own account engaged in practices of critique. The old stories were restaged with plots and characters newly contrived to place cultural values and assumptions about reality (ethos and worldview) under stress, identifying and interrogating the stress through hypothetical, "what if" questioning ${ }^{21}$. What if a King in apparent ignorance and a city-call it Thebes-in consoling, somnambulant complacency failed to address an old injustice? How would they respond to such a revelation? Could they reach resolution-or would the crimes be compounded, generation after generation? Perhaps the activities of the festival of Dionysus did create an "aura of factuality" (Geertz), but the nature of the theatrical questioning insisted that the aura be interrogated. The ritual of mimesis was not merely imitative in the sense of repetitive sameness, but critical and interrogative. On this account, a Bertolt Brecht, Suzan-Lori Parks, and Wole Soyinka could be deemed Aristotelean-like performance critics $^{22}$. So too, for that matter, could be a Michel Foucault and Judith Butler or a Richard Shechner and Catherine Bell. Theorists dramatize. Plays and performances theorize. All would be self-chastened ritualizers.

We want to conclude this introduction with a brief preview of the essays in this Special Issue. The topics considered cover a wide cultural and temporal geography.

Some of the included scholars approach the work of theatrical phenomena operating inside of, out from, and alongside "religious" contexts. Daniela Cavallaro's essay explores how Catholic Christian religious communities-in both the sixteenth and twentieth centuries - employed theatrical dramas about the afterlife as a pedagogical tool. Her work not only introduces and contextualizes examples from Jesuit and Salesian educational

19 Benjamin defines "aura" as the quasi-spiritual marker of authenticity and tradition contained by an original work of art that is subsequently lost or removed by mechanical reproduction. The process "detaches the reproduced object from the domain of tradition" (Benjamin 1969, p. 221). Theatrical drama, in not being mechanically "reproduced", can retain something of aura's immediacy and religious overtone.

20 Muñoz describes this "burden of liveness" as a "hegemonic mandate that calls the minoritarian subject to 'be live' for the purpose of entertaining elites" (Muñoz 1999, p. 182). Minoritized identities are only celebrated-perhaps only sanctioned—during these "live" performances; similar points could be made regarding the entertainment value of indigenous religious ceremonies for tourists. Muñoz frames the burden of liveness as a critique of both the imperative to study only live performance (his work includes film and art installations), as well as the separation of minoritized cultures from the temporality of political life. "If the minoritarian subject can only exist in the moment, she or he does not have the privilege or pleasure of being a historical subject. If that subjects needs to focus solely on the present, it can never afford the luxury of thinking about the future" (Muñoz 1999, p. 189).

21 See (Redfield 1975, chps 1-2) on Aristotle and tragedy; see (Nussbaum 1986, pp. 122-35).

22 Brechtians typically have disdain for the consoling, emotional release of catharsis often attributed to the Poetics; Redfield, however, argues (Redfield 1975, pp. 68, 87, 236-38; also Nussbaum 1986, p. 385) that catharsis in Aristotle (used but once in the Poetics, once in the Politics) better aligns with his view of the cognitive pleasures of learning and reasoning-out that we take from art generally. Such a view of art and theater would not be alien to Brecht. 
theater, but also identifies how theatrical drama reflected the theological and political concerns of these communities (Cavallaro 2019).

Theatrical drama might also pass along religious sensibilities beyond a shared cloister or even explicit causal chain. Dana Tanner-Kennedy, for instance, elucidates how the echoes of metaphysical religion resound across Gertrude Stein's theory of landscape and in her Four Saints in Three Acts. Tanner-Kennedy's essay shows how Gertrude Stein's plays and other meditative writing forge indirect links between metaphysical religious thought and later avant-garde theater in the United States (Tanner-Kennedy 2020).

Theatrical drama can also become the site for multiple religious contexts to overlap on stage. Michael VanZandt Collins' essay engages the case of a particular staging of Shakespeare's Romeo and Juliet where "mutual witnessing" opens possibilities for comparative theology. Like that performance's juxtaposition of star-crossed lovers and war-torn Syria, VanZandt Collins occasions new insights between Islamic and Christian theologies of martyrdom and witnessing truth (VanZandt Collins 2020).

Other essays open new avenues to understanding theatrical drama and dramaturgical theories by utilizing religion as an interpretive key. Charles A. Gillespie, for instance, offers "Showtime" as a way to make sense of theatrical temporalities by borrowing terms from Christian theology. Gillespie finds tools to interpret the Iranian experimental playwright, Nassim Soleimanpour, in Hans Urs von Balthasar's dramatic theory (Gillespie 2020).

Putting theatrical drama in the company of theological ideas can also provide new ways to interpret "canonical" texts. David Urban reads Ibsen's A Doll House alongside New Testament texts and Protestant Christian notions of love and self-sacrifice. Urban's essay uncovers and critiques what he calls the "religion of Torvald" that shines new light on the motivations and implications for Nora's choices, as well as scholarly takes on the play (Urban 2020).

Religion does more work for the interpretation of theatrical drama than identify contexts or categorize traditional references. Larry D. Bouchard proposes "metatheatre" as the place to track what might be a latent religious dimension in theatrical drama beyond that of ritual. Surveying three sorts of metatheatre in both Wilder's Our Town and Sondheim's Sunday in the Park with George, Bouchard brings into focus what might be religious about experiences at these shows' "limits" (Bouchard 2020).

Theatrical drama provides other authors with tools to expand interpretive categories beyond supposed limits and presumed itineraries, especially regarding the meanings of the body. Religious themes of martyrdom appear in Tom Fish's consideration of "gender virtuosity" in The Virgin Martyr, a 1622 collaboration between Thomas Dekker and Philip Massinger. Rather than rehash scholarly debates about Catholic vs. Protestant interpretations, Fish turns our attention to how The Virgin Martyr theatricalizes gendered bodies to represent and perhaps persuade spiritual conversions and miraculous (even bewitching) reversals of norms (Fish 2019).

Bodies that perform theatrical drama also lend the spectacle of their physical weight to a play's rhetorical meanings. Emily Bryan's essay re-evaluates the many substitutions in Shakespeare's Measure for Measure by looking at the performing triads in Cheek by Jowl's recent production. Semiotic theories invite Bryan to notice unexpected suggestions of the Christian doctrine of the Trinity through triadic logic and triadic imagery on stage (Bryan 2020).

Theatrical drama prompts such surprising re-combinations. Adam Beyt's essay identifies how the musical Hedwig and the Angry Inch functions as a religious classic by subverting the logic of sexual complementarity in Christian theological anthropology. Beyt puts Hedwig's religious symbols in dialogue with John Paul II and Judith Butler to interrogate normative "completeness" and mythological expectations about love (Beyt 2019).

With this Special Issue, we invited contributors to take up or challenge the sorts of questions raised by our call for papers and this Introduction. We encouraged contributors to press considerations or reconsiderations of religion and theatrical drama in unexpected directions. Our aim now is not to conclude these conversations by dropping a final curtain, 
but to demonstrate theatrical drama's persistent importance for and contribution to the study of religion. By illuminating these juxtaposed worlds, we seek fresh revivals of longstanding conversations, as well as new scene partners ready to ask, "What if?" in the ghost light.

Funding: This research received no external funding.

Conflicts of Interest: The authors declare no conflict of interest.

\section{References}

Abel, Lionel. 1963. Metatheatre: A New View of a Dramatic Form. New York: Hill and Wang.

Artaud, Antonin. 1958. The Theater and Its Double. Translated by Mary Caroline Richards. New York: Grove City Press.

Barish, Jonas. 1981. The Antitheatrical Prejudice. Berkeley: University of California Press.

Beckwith, Sarah. 2001. Signifying God: Social Relations and Symbolic Act in the York Corpus Christi Plays. Chicago: University of Chicago Press.

Beckwith, Sarah. 2011. Shakespeare and Forgiveness. Ithaca: Cornell University Press.

Bell, Catherine. 2009. Ritual Theory, Ritual Practice. Oxford: Oxford University Press.

Benjamin, Walter. 1969. The Work of Art in the Age of Mechanical Reproduction. In Illuminations. Edited by Hannah Arendt. Translated by Harry Zohn. New York: Schocken.

Beyt, Adam. 2019. 'Beautiful and New': The Logic of Complementarity in Hedwig and the Angry Inch. Religions 10: 620. [CrossRef]

Bial, Henry. 2015. Playing God: The Bible on the Broadway Stage. Ann Arbor: University of Michigan Press.

Bouchard, Larry D. 2011. Theater and Integrity: Emptying Selves in Drama, Ethics, and Religion. Evanston: Northwestern University Press.

Bouchard, Larry D. 2020. Religion and the Limits of Metatheatre in Our Town and Sunday in the Park with George. Religions 11: 94. [CrossRef]

Brecht, Bertolt. 1964. Brecht on Theatre: The Development of an Aesthetic. Translated by John Willett. New York: Hill and Wang. First published 1957.

Brook, Peter. 1968. The Empty Space. New York: Atheneum.

Bryan, Emily. 2020. 'Fantastic Tricks before High Heaven,' Measure for Measure and Performing Triads. Religions 11: 100. [CrossRef]

Cavallaro, Daniela. 2019. Go and Sin No More: The Afterlife as Moral Teaching in Italian Catholic Educational Theatre. Religions 10: 517. [CrossRef]

Craigo-Snell, Shannon. 2014. The Empty Church: Theater, Theology, and Bodily Hope. Oxford: Oxford University Press.

Dox, Donalee. 2016. Reckoning with the Spirit in the Paradigm of Performance. Ann Arbor: University of Michigan Press.

Driver, Tom F. 1970. Romantic Quest and Modern Query: A History of the Modern Theater. New York: Delacorte.

Driver, Tom F. 1998. Liberating Rites: Understanding the Transformative Power of Ritual. Boulder: Westview.

Fish, Tom. 2019. Bewitching Power: The Virtuosity of Gender in Dekker and Massinger's The Virgin Martyr. Religions 10: 629. [CrossRef]

Fisher, James. 2015. Historical Dictionary of American Theatre: Beginnings. Lanham: Rowman \& Littlefield.

Freeman, Lisa A. 2017. Antitheatricality and the Body Politic. Philadelphia: University of Pennsylvania Press.

Gadamer, Hans-Georg. 1989. Truth and Method, rev. ed. Translated by Joel Weinsheimer, and Donald G. Marshal. New York: Continuum.

Gillespie, Charles A. 2019. Drama Alone is Credible: Hans Urs von Balthasar and the Interpretive Work of Theatre and Performance in Twentieth-Century Christian Thought. Ph.D. dissertation, University of Virginia, Charlottesville, VA, USA.

Gillespie, Charles A. 2020. Theodramatic Themes and Showtime in Nassim Soleimanpour's White Rabbit Red Rabbit. Religions 11: 499. [CrossRef]

Greenblatt, Stephen. 1988. Shakespearian Negotiations: The Circulation of Social Energy in Renaissance England. Berkeley: University of California Press.

Greenblatt, Stephen. 1993. Shakespeare Bewitched. In Historical Literary Study: Essays on Reproducing Texts, Representing History. Edited by Jeffrey N. Cox and Larry J. Reynolds. Princeton: Princeton University Press.

Greenblatt, Stephen. 2001. Hamlet in Purgatory. Princeton: Princeton University Press.

Greenblatt, Stephen. 2004. Will in the World: How Shakespeare Became Shakespeare. New York: Norton.

Hornby, Richard. 1995. Script into Performance: A Structuralist Approach. New York: Applause. First published 1977.

Knapp, Jeffrey. 2002. Shakespeare's Tribe: Church, Nation, and Theater in Renaissance England. Chicago: University of Chicago Press.

Muñoz, José Esteban. 1999. Disidentifications: Queers of Color and the Performance of Politics. Minneapolis: University of Minnesota Press.

Nussbaum, Martha C. 1986. The Fragility of Goodness: Luck and Ethics in Greek Tragedy and Philosophy. Cambridge: Cambridge University Press.

Redfield, James M. 1975. Nature and Culture in the Iliad: The Tragedy of Hector. Chicago: University of Chicago Press.

Rouse, John. 2007. Brecht and the Contradictory Actor. In Critical Theory and Performance, revised ed. Edited by Janelle G. Reinelt and Joseph R. Roach. Ann Arbor: University of Michigan Press.

Schechner, Richard. 1977. Drama, Script, Theater, and Performance. In Essays on Performance Theory, 1970-1976. New York: Drama Book Specialists. 
Schechner, Richard. 1985. Between Theater and Anthropology. Philadelphia: University of Pennsylvania Press.

Schleiermacher, Friedrich. 1996. On Religion: Speeches to Its Cultured Despisers. Translated by Richard Crouter. Cambridge: Cambridge University Press. First published 1799.

Shakespeare, William. 2015. Macbeth. Edited by Sandra Clark and Pamela Mason. London: Bloomsbury.

Shephard, William Hunter. 1991. The Dionysus Group. New York: Peter Lang.

Tanner-Kennedy, Dana. 2020. Gertrude Stein and the Metaphysical Avant-Garde. Religions 11: 152. [CrossRef]

The Performance Group. 1970. Dionysus in '69. Edited by Richard Schechner. New York: Farrar, Straus and Giroux.

Urban, David V. 2020. Nora's Ironic Longing for Christlike Love: Self-Sacrifice, Self-Love, and the 'Religion of Torvald' in Ibsen's $A$ Doll House. Religions 11: 318. [CrossRef]

Vander Lugt, Wesley, and Trevor Hart, eds. 2014. Theatrical Theology: Explorations in Performing the Faith. Cambridge: Lutterworth Press. Vanhoozer, Kevin J. 2005. The Drama of Doctrine: A Canonical-Linguistic Approach to Christian Theology. Louisville: Westminster John Knox Press.

Vanhoozer, Kevin J. 2014. Faith Speaking Understanding: Performing the Drama of Doctrine. Louisville: Westminster John Knox Press.

VanZandt Collins, Michael. 2020. Toward Witnessing the Other: Syria, Islam and Frans van der Lugt. Religions 11: 174. [CrossRef] von Balthasar, Hans Urs. 1988. Theo-Drama I: Prolegomena. Translated by Graham Harrison. San Francisco: Ignatius.

von Balthasar, Hans Urs. 1990. Theo-Drama II: Dramatis Personae: Man in God. Translated by Graham Harrison. San Francisco: Ignatius. von Balthasar, Hans Urs. 1992. Theo-Drama III: Dramatis Personae: Persons in Christ. Translated by Graham Harrison. San Francisco: Ignatius.

von Balthasar, Hans Urs. 1994. Theo-Drama IV: The Action. Translated by Graham Harrison. San Francisco: Ignatius. von Balthasar, Hans Urs. 1998. Theo-Drama V: The Last Act. Translated by Graham Harrison. San Francisco: Ignatius. Wiles, David. 1997. Tragedy in Athens: Performance Space and Theatrical Meaning. Cambridge: Cambridge University Press. 

Article

\title{
Go and Sin No More: The Afterlife as Moral Teaching in Italian Catholic Educational Theatre
}

\author{
Daniela Cavallaro
}

School of Cultures, Languages and Linguistics, University of Auckland, Auckland 1142, New Zealand; d.cavallaro@auckland.ac.nz

Received: 12 July 2019; Accepted: 3 September 2019; Published: 6 September 2019

\begin{abstract}
Catholic religious orders that have education as part of their mission have often used visions of the afterlife in theatre productions as vehicles to transmit a message of conversion, especially to those who, because of age or illiteracy, would not benefit as much from Scripture readings or complex sermons. In this article, I look at how such visions of the blessed and the damned, of heaven and hell, of angels and demons, were used in educational theatre in Italy by the Jesuits in the 16th century and the Salesian sisters in the 20th century. The historical background for the Jesuit and Salesian plays I analyze also reveals a propagandistic layer of meaning in their representation of the afterworld, as the Jesuits' tragedies date to the years of the Counter-reformation, while the Salesian sisters' plays belong to era of the cold war. Thus, the Jesuit and Salesian theatrical depictions of heaven and hell provide insight not only into the religious understanding of the eras, but also into the social and political concerns of the times in which they were composed, as well as the diverse educational messages transmitted to young men and young women.
\end{abstract}

Keywords: heaven; hell; purgatory; Jesuits; Salesians; drama; education; Italy

\section{Introduction: The Good Place and the Bad Place}

In early 2018, an interview by journalist Eugenio Scalfari of La Repubblica with Pope Francis (Scalfari 2018) made world-wide headlines: "The Holy Father, the Supreme Pontiff, the infallible definer of Catholic doctrine, said nope, he doesn't believe in hell", reported one newspaper in New Zealand (Lapsley 2018). "Pope Francis 'abolishes hell', saying souls of unrepentant sinners will simply disappear", stated the Times (Willan 2018). Although quickly contested by the Vatican (Parole del Papa 2018), the reported words of Pope Francis on hell not being an actual place seemed to complement what he had said regarding heaven during the general audience of 26 November 2014. More than a place, he affirmed, heaven "is a 'state' of soul in which our deepest hopes are fulfilled in superabundance and our being, as creatures and as children of God, reach their full maturity". There, he added, we "will finally be clothed in the joy, peace and love of God, completely, without any limit, and we will come face to face with Him!" (Francis 2014).

Today, perhaps, the suggestion that heaven and hell might not be actual places may correspond to widespread beliefs. Even those who believe in the existence of an afterlife can disagree as to what it might look like (Paradise Polled 2015), or as to how the good and bad places might even differ (as in the 2016-2019 Netflix series "The Good Place"). In 16th century Italy, however, there was no such confusion. Christians lived their lives knowing beyond doubt that the dies irae-the day of wrath-was imminent. ${ }^{1}$ On that day, the world would dissolve into ashes; with universal dread the Book of

1 In fact, according to Mirko Breitenstein, daily life during the Middle ages presented these two challenges: "to know that there are representatives from the other world, and to behave towards them adequately, that is, to search them or to flee 
Consciences would be read out-judging the living and the dead; at that very moment "when the doomed can no more flee from the fires of misery", the sheep would be separated from the goats, the righteous would shine like the sun in the kingdom of their Father, while the sinners would be cast into the fiery furnaces where there would be but weeping and gnashing of teeth (Dies Irae 1998). ${ }^{2}$ If there were a choice between spending eternity dancing in a heavenly garden with the saints and angels, or being chewed to pieces by Satan, ${ }^{3}$ most believers would try to behave in such a way as to be destined to the good place and not the bad.

Catholic religious orders that have education as part of their charism ${ }^{4}$ have often used visions of the afterlife in theatre productions as vehicles to transmit a message of conversion, especially to those who, because of age or illiteracy, would not benefit as much from Scripture readings or complex sermons. ${ }^{5}$ The goals of such plays set in heaven and hell, with angels and demons, the blessed and the damned-in addition to being visually entertaining, with special costumes, light and smoke effects-were meant to move a young or illiterate audience to follow or avoid the examples of others who now witnessed the experience of eternal triumph or suffering. These plays did not debate the existence of heaven and hell; in a Catholic setting, such an understanding of the afterlife was taken for granted. Rather, they indicated what kind of people, and sometimes, like Dante Alighieri, even which historical figures, would go there-and thus they educated the spectators on which role model to follow.

In this article, I will look at how such visions of the blessed and the damned, of heaven and hell, of angels and demons, were used in educational theatre in Italy both by Jesuit priests in the 16th and 17th centuries, and Salesian sisters in the 20th century. My goal is to discuss how the afterlife was used in theatre for the education of the youth during these centuries. I have chosen these two congregations in particular because both used theatre as an essential part of their educational system. Moreover, given that the Jesuits educated only young men, and the Salesian sisters only young women, the diverse blessed and damned souls that they stage allow us to discuss what virtues and vices young men and women were to pursue or avoid. Finally, the historical background for the Jesuit and Salesian plays that I will analyze will also help uncover a propagandistic layer of meaning in their representation of the afterworld, as the Jesuits' tragedies date to the years of the counter-reformation, while the Salesian sisters' plays belong to the era of the cold war. These two periods, although separated by some four centuries, include similarities of political and religious tensions, each creating a climate of disagreement and suspicion which gave rise to anti-protestant (in the counterreformation years) and anti-Communist (in the 20th century) beliefs and propaganda within Catholic religious institutions. Thus, the Jesuit and Salesian theatrical depictions of heaven and hell which I will discuss will provide insight into not only the religious understanding of the eras, but also the social and political concerns of the times in which they were composed, as well as the diverse educational messages transmitted to young men and young women.

\section{Jesuit Theatre and the Afterlife}

The connection between theatre and the Catholic church dates at least to the middle ages. In fact, the earliest recorded theatre in Western Europe appears to be the liturgical drama of the church,

from them [and] to develop strategies in order to avoid hell or to reach heaven within the Beyond after death" (Breitenstein 2018, p. 122).

2 See, for example, Mt 13: 41-43.

3 See, for example, the dance of the blessed in Beato Angelico's "Last Judgment", in the Museo Nazionale di San Marco of Florence, or the depiction of Satan chewing on the bodies of the damned in the "Last Judgment" by Coppo di Marcovaldo, in the Battistero di S. Giovanni in Florence. For early modern artistic depictions of heaven and hell, see Hughes (1968).

4 In the New Testament, the word 'charism' refers to a spiritual gift given to individuals through divine grace (1Corinthians 12) or gifts of community leadership (Ephesians 4: 1-16). In Catholic theology, it has come to refer to the particular form of service to the church that a religious congregation has chosen or inherited from their founder (McFarland 2011).

5 Several religious orders also used theatre as a vehicle for evangelization in missions abroad. See, for example, Isgrò (2015). 
used to tell stories from the Bible, teach doctrine and encourage good behavior. In Italy, the oldest remaining dramatic text is a 12th century lament of the Virgin Mary at the foot of the cross, part of a passion play. Other genres that flourished in the middle ages were the lives of the saints and sacred plays (Medieval Drama 2000). Beginning about the time of the Renaissance, the educational purpose of Catholic theatre expanded from the churches and the squares to the schools of those religious orders that devoted themselves to the education of the youth. This form of Catholic educational theatre reached its maximum success with the plays performed in Jesuit schools in the 16th and 17th centuries. ${ }^{6}$

The Jesuits opened their first Italian college in Messina in 1548; by 1556, the year their founder Ignatius Loyola died, they had established some twenty colleges throughout Italy and several more throughout Europe. By 1773, when the order was suppressed, there were about 700 Jesuit schools in Europe and 100 in the rest of the world (Grendler 2014, p. 8; Sani 2009, pp. 33-34). ${ }^{7}$

Jesuit education was meant to confirm Catholic youth in their faith, confute heresy, and educate future leaders toward the good of society (Grendler 2014, p. 9). From nearly the beginning, theatre had a role in achieving these goals. "The Jesuits embraced theater as a didactic tool" explains Kevin Wetmore, "even as they feared its potential for immorality. They recognized its power, but worked to ensure the students seeing and performing the shows realized the drama was a means to an end, not an end in and of itself" (Wetmore 2016). Already by 1555, or possibly even earlier, ${ }^{8}$ comedies and tragedies began to be performed in Jesuit schools (Oldani and Yanitelli 1999, p. 18), ${ }^{9}$ bringing several benefits to both the students and the school. Students gained exercise in memory and Latin as well as acquiring virtue by emulation. In addition, since Jesuit performances on special occasions (the feast of a patron saint, or a prizegiving ceremony) were open not only to school members but to the entire community, theatre was as well "a form of advertising for Jesuit education, but also [ ... ] a way of dialogue and alliance with civil and religious authorities" (Gallo 2018). Finally, the public nature of educational theatre helped the schools' prospects of gaining the support of wealthy donors (Sani 2009, p. 44). In 1556, in a letter to "Those Going to Begin the College in Prague by Commission", Ignatius himself encouraged the staging of plays "to aid and encourage the students and their families and to gain authority for the classes" (Ignatius of Loyola 2006, p. 636).

Because it was part of the Jesuits' educational system, theatre in the Jesuit tradition had to follow rules that were spelled out in the Ratio Studiorum of 1599: “Tragedies and comedies must be in Latin, and they must be very few. Their subjects should be religious and edifying, and there should be no interludes that are not in Latin and in good taste. No female characters or costumes may be used" (McCabe 1983, p. 14). ${ }^{10}$ Thus, most Jesuit plays, at least for the first century, were in Latin. To facilitate understanding, a summary of the events of the play in the vernacular would often form the preface to the publication, be distributed to the audience or, in some cases, even read aloud before each act (Saulini 2002, p. 50). Plays were distinguished as either ludi solemnes, that is, tragedies performed

6 The bibliography on Jesuit theatre is constantly growing, from the seminal article by Schnitzler (1952) to the more recent O'Malley (2013); Wetmore (2016) and Gallo (2018); see also Oldani and Yanitelli (1999); Sani (2009) and Zanlonghi (2004, 2006) for Jesuit theatre in Italy in particular.

Elissa Weaver has suggested that the Jesuits may have been aware of and possibly influenced by the tradition of theatre used in the education of young women in convents before the establishment of Jesuit schools (Weaver 2002, p. 4). Some of the theatrical works staged in convents in Renaissance Florence also had angels and devils as characters and referred to the joys or torment of the afterlife as consequences of the choices made during one's life. See for example Haraguchi (2009) on Rappresentazione delle virtù e dei vizi [Play of the Virtues and Vices] (1650) by Eleonora de Montalvo (1602-1659). Using the structure of the parable of the wise and foolish virgins, this play shows one group taken by St Michael the archangel at the moment of their death, while the second-those that did not repent in time-is dragged away by Lucifer.

7 Jesuit schools were open to males of all social classes "who could pass the courses and obey the rules"; there was no tuition fee to pay (O'Malley 2013, p. 59). The number of students would range from 100 to more than 2000 in individual schools, with an average of about 400 (McCabe 1983, pp. 8-9).

$8 \quad$ McCabe states that there is evidence of plays being staged in Messina even in 1551 (1983, p. 38).

9 Performance of drama in Latin by Plautus and Terence was already part of Humanistic schools in Florence (Black 2007, p. 164).

10 These rules appear somewhat more relaxed than previous ones. For example, in the guidelines emitted in 1591, there was also a prohibition of women spectators (McCabe 1983, p. 13). 
by senior students, or ludi priores, often comedies performed during the Carnival season by younger students (Oldani and Yanitelli 1999, p. 18). There was a tendency to not reuse a play which had already been staged in another college, hence the necessity to create always new works. William McCabe calculates the number of plays produced in Jesuit colleges "conservatively at nearly one hundred thousand" (McCabe 1983, p. 47). Schnitzler claims, however, that although plays may have been new, they may not have been entirely original, as they would follow a typical dramatic scheme and an ethical message which reflected the mission of the order, that is, the salvation of the souls: "every play was to exalt the blessing of a devout life and to inspire the audience with the Christian values of humility and piety" (Schnitzler 1952, p. 285). This common theme was used in a variety of theatrical genres, from tragedy to comedy, and pastoral play to pantomime, including even farce, opera and ballet (Schnitzler 1952, p. 286). In many cases, however, summaries are all that are left of the thousands of plays written for Jesuit theatre (Filippi 2001, pp. 13-15). ${ }^{11}$

Looking at the summaries of these numerous plays, it is evident that most would focus on the fight between good and evil, the battle between the two forces that vie for the human soul and the salvation of the world, as embodied on stage in the characters of Christ and Satan (Saulini 2002, p. 42). In fact, the aspect of Jesuit drama that I intend to explore here is the use of allegorical figures, be it the personification of ideas, or supernatural characters such as angels and demons. Such characters "were used in frequent dream scenes, in episodes showing magicians and sorcerers at work, in frightening images of Hell, or in dazzling visions of Heaven" (Schnitzler 1952, p. 286). ${ }^{12}$ While on the stage itself human life developed, moving from town to forest, or fortress to port, "from heaven descend[ed] patron saints; angels and allegorical characters show[ed] themselves from the clouds; while from the abyss there suddenly emerge[d] demons, infernal spirits and magical prodigies" (Filippi 2001, p. 55). ${ }^{13}$ Thus, the use of special effects on stage would deeply affect the spectators' senses, rendering more effective the educational message presented in the play even for illiterate audiences (Schnitzler 1952, p. 288). ${ }^{14}$

This "tendency to exhibit constant activity" on stage was certainly due to the needs and preferences of the audience (McCabe 1983, p. 64). But the reason behind such effects also connects to Jesuit spirituality: as part of the spiritual exercises, Ignatius Loyola instructed on the "application of the senses" to make one's meditation or contemplation more effective. In other words, as Wetmore (2016) summarizes, "the Ignatian Spiritual Exercises are a form of acting exercise in which one imagines oneself as a character in various biblical situations and explores what it means, physically, emotionally, and (most important) spiritually to experience it".

In the Jesuit tradition, therefore, theatre and spiritual exercises unite; theatre is, in fact, rooted in Ignatian spirituality. Consider the Spiritual Exercises themselves: in the fifth exercise of the first week of the Spiritual exercises, the exercitants are instructed to imagine themselves in hell. First, they should "see with the eyes of the imagination the huge fires and, so to speak, the souls within the bodies full of fire". Then, "hear the wailing, the shrieking, the cries, and the blasphemies against our Lord and all his saints". After seeing and hearing, the exercitants will have to employ their other three senses, as they are instructed to experience "the smoke, the sulphur, the filth and the rotting things [... ] the bitter flavors of hell: tears, sadness and the worm of conscience [ . . . and finally] feel how the flames touch the souls and burn them" (Ignatius of Loyola 1991, p. 141).

In the second week of the exercises, on the fourth day, we see another image that will influence Jesuit theatre, as the exercitant is further invited to visualize "Christ, our supreme commander and

11 See Filippi (2001, pp. 16-26) for a description and discussion of the remaining Jesuit theatre scenarios.

12 Schnitzler (1952, p. 287) also points to another important characteristic of Jesuit theatre, which is the use of elaborate stage effects: scenic effects, trap doors, costumes, music, light and sound.

13 All translations of quotations from the Italian and Latin in this article are mine. I am grateful to Dr. Christina Robertson of the University of Auckland for her help with the Latin texts.

14 That is one of the reasons why Jesuits used theatre with such great success in their missions abroad (Schnitzler 1952, p. 285) and within Italy as well (Selwyn 2004, pp. 211-18). 
Lord" and "Lucifer, the mortal enemy of our human nature"; each wants all humans to militate under his standard. ${ }^{15}$ The images invoked in the exercise present a battlefield, in which both commanders prepare their armies. ${ }^{16}$ The section that is relevant to Jesuit theatrical representations is the description of Lucifer as commander-in-chief, as well as a list of his deceits. The penitent is instructed to imagine the devil "in that great plain of Babylon. He is seated on a throne of fire and smoke, in aspect horrible and terrifying" as he "summons uncountable devils, disperses some to one city and others to another, and thus reaches into the whole world". He then tells them "to set out snares and chains", to lure men with promises of riches, then honor, then pride; "and from these three steps the enemy entices them to any other vices" (Ignatius of Loyola 1991, pp. 154-55). In other words, it would appear that according to Ignatius Loyola himself, the root of all evil is not so much the pursuit of pleasure as the quest for riches, honor and pride. ${ }^{17}$

In many of the Jesuit plays, similar demons and angels appear as part of the background action, as for example in the The apotheosis or consecration of Saints Ignatius and Francis Xavier, staged for the first time in 1622 at the Collegio Romano on the occasion of the canonization of Ignatius Loyola and Francis Xavier. Mixing acting, opera and ballet, the play contained scenes set in hell, as well as acts in which demons attacked the saints (Wetmore 2016). The play ended with "a spectacular earthquake [which] gives way to an opening in the heavens [and] all the countries prostrat[ing] themselves before the new saints and a chorus of angels" (Cohelho 1997, p. 31). In another play, also staged in 1622 for the celebration of the canonization of Francis Xavier, Pirimalo ${ }^{18}$ by Gino Angelo Capponi, infernal spirits "emerge furiously and impetuously from a horrid cave" attempting to distract Francis Xavier from prayer (Filippi 2001, pp. 108-9). ${ }^{19}$ Just as demons try to interfere with the life of humans, in the same play Francis Xavier's guardian angel, armed with lightening, intervenes in a human battle defeating and submerging the enemy ships.

Among the many works of Jesuit theatre where angels and devils show their influence on human souls, two in particular stand out, as their entire Latin text remains: Stefano Tuccio's Christus Iudex [The Judging Christ], first staged in Messina in 1569, and Vincenzo Guiniggi's Ignatius arma mutans [Ignatius changing arms] first staged in Rome in $1622 .{ }^{20}$ Christus Iudex enacts the very day of judgment, when souls are eternally assigned to heaven or hell, the last and only moment in human history in which there will no longer exist the possibility of repentance. Ignatius arma mutans, on the other hand, allows spectators to see the demonic forces at work throughout human history, even in the present, warning against those human ambitions and desires which, though they might appear justifiable, may well be of demonic origin. Thus, both plays stage angelic and demonic figures as characters, and heaven and

15 See Conrod (2010) on the importance of creating an image of Hell as a place of eternal punishment for indigenous populations that did not have a hell as part of their cosmology.

16 See Prosperi (2015, pp. 368-69) for the imagery of the two standards: "The two standards are those of Christ and Lucifer, the two captains who, according to military practice, planted their standards and enlisted those willing to gather under their ensigns. [...] The vision presented for the fourth day is of the whole world as a place of conflict where the armies of the two opposing captains line up and confront each other".

17 See Mk 1: 12-13, Lk 4: 1-13, and Mt 4: 1-11 where the devil tempted Jesus himself with riches, honor and pride.

18 The play staged the martyrdom of Pirimalo, prince of Ceylon, killed by his father the day after he was baptized by Francis Xavier.

19 Demons also appear in Leone Santi's Il gigante [The giant] (1632), a retelling in Italian of the story of David and Goliath. In the first scene of the second act, the play stages an infernal council modelled on Canto IV of Gerusalemme liberata. The council concludes in a scene of music and dance. Lucifer and other demons are also present in Isacco [Isaac] by Antonio Casilio staged in 1637 (Filippi 2001, pp. 159-66). A dance of devils who predict the crown for a cruel and revengeful tyrant is mentioned in the argument for the Italian tragedy Alessio Comneno (1674) of unknown author (Filippi 2001, pp. 348-51). An infernal spirit declares to have abandoned hell and has taken up human form in order to act as a tempter of the protagonist in the hagiographic play Alessio (1690) of unknown author (Filippi 2001, pp. 378-80). The celebrated tragedy Crispo by Bernardino Stefonio, modelled on Seneca's Phaedra, staged multiple times after its 1596 premiere at the Collegio Romano, also has scenes that take place in hell. More specifically, hell opens and Fausta (the protagonist's lying stepmother) is set up by demons on a throne and shown honors (Filippi 2001, p. 457).

20 Future cardinal Giulio Mazzarino played the role of the protagonist Ignatius (Filippi 2001, p. 62). 
hell as locations, in order to offer their actors and spectators an educational message on the need to repent now and follow a virtuous life.

\section{Stefano Tuccio's Christus Iudex}

Sicilian Jesuit Stefano Tuccio (1540-1597)—educator, orator, poet, priest, theologian and playwright-is well known for his use of angels and devils and their influence on human nature in many of his biblical and Christological theatrical works. ${ }^{21}$ In his 1564 play Giuditta, based on the biblical character of Judith, for example, the demon Asmodeo enters Olophernes' dream convincing him to try to seduce Judith, thus suggesting to the audience a connection between sexual arousal and the devil in this story (Saulini 2002, p. 81). In his Christus patiens (1569), on the passion of Jesus, during a scene set in hell, the aptly named Cacodemon encourages several of the souls to recount their past lives of sin. In this particular case, the souls of the damned were chosen as representatives of their profession: a politician, a rich man, a lecher, and a philosopher. They all blame their ignorance of the consequences of their earthly behavior on their eternal life. The politician asks: "Why during the course of our lives did nobody show us the miseries, what course each of us should follow, what behaviors or frames of mind were best in life?" The rich man admits to being thirstier for gold than charity, but "nobody lived with me who could show me the riches of the life to come" (Tuccius 2011, p. 82). The same play also stages the descent to earth of archangels Gabriel, Raphael and Michael with the intention of freeing Jesus from his suffering on the cross, a help which, however, he refuses: "There is no need of your help; put away your swords [ ... ] let this go, nothing is hard which this happy destiny will follow" (Tuccius 2011, p. 130). Such a scene would have served both symbolic and theatrical purposes, as yet a further demonstration of the strength of the forces of good opposed to those of evil, as well as a spectacular use of theatrical machines that would have allowed for a descent from heaven of the three angels (Saulini 2002, p. 109).

The most famous of Tuccio's tragedies is the aforementioned Christus Iudex, also known as De Ultimo Dei Iudicio [The last judgment], which is reported to have caused many conversions among its spectators (Saulini 2002, p. 113). ${ }^{22}$ The educational intent of the play emerges even from the prologue, which explicitly states that spectators should learn such behaviors as will obtain clemency from God the judge. Like a modern-day Jonah calling Nineveh to conversion, a subsequent address summons the city of Messina to purification and repentance or the city will be destroyed by plague, famine, storm, sweeping sea waters and a devouring flame: "The flame will destroy those ports and travelled shores you are so proud of. The flame will destroy your high walls. The flame will turn to ashes your crops and your fields scattered with fruits, your meadows and your homes" (Tuccius 2011, p. 148). In addition to anticipating the apocalyptical images that will be developed in the play itself, the prologue serves as a reminder to the citizens of Messina, a city that was known for its wealth, culture and independent spirit among Sicilian towns, that the desire for riches is the root of all evil (Saulini 2002, pp. 120-21). ${ }^{23}$

Though the prologue may elicit images of Old Testament prophecy, Christus Iudex finds its main source in Revelation 20: 2-11, staging the end times, when Satan, the antichrist, is set free of his 1000-year bondage before the impending final judgement of Christ (Saulini 2002, p. 116). Set in Jerusalem, heaven and hell, the play would have afforded spectacular scenes of angels descending from heaven into hell, as Michael does in obedience to Jesus' order to free the arch-enemy "such that with a sinister light he might corrupt the peoples and begin the ultimate ruin of the world [ ... ] disturb the realms of men, the seas, and the people who live in peace" (Tuccius 2011, p. 158). It would also have allowed for scenes of battle, meant to showcase the physical and military skills acquired by students in

21 Saulini (2002) offers an exhaustive introduction to Tuccio's life and works.

22 On the difference between the play as staged in Rome and Messina, see Saulini (1999). See also Saulini (2002, p. 179) for the debates over the date of the first performance at the Collegio Romano.

23 See 1Tim 6: 10. 
a Jesuit school, as well as, in the last act, the moment of the final judgment itself, when Christ gives his sentence first against the devil and then against each and every human being. The souls of the damned hurl themselves to the ground pleading for mercy first from the Judge, then from the angels and the saints. But their cries go unheard. As Christ rises to heaven with the blessed, the condemned remain behind weeping and gnashing their teeth until that time when Michael the Archangel utters his last command: "I order you, Acheron, to gape open, splitting the earth, and snatch away these souls plunged headlong into the deepest heart of Dis [... ] And now, crushing the damned three times with my heel, I fasten the gates with iron bars forever" (Tuccius 2011, p. 268). And thus does our tragedy end.

As in most Jesuit plays where there is an abundance of spectacular activity on stage, one wonders how their technical skills would have allowed, for example, for the many blessed to be taken into heaven, or for the earth to swallow the damned. That aside, however, one scene, though less spectacular, stands out as far more significant from an educational point of view, as it displays the Jesuits' educational goals, united with their propagandistic spirit. At the end of the play, after the final judgment, following the example of Dante's Inferno written more than two centuries before, the author gives one last opportunity for some of those souls condemned for eternity to speak: the first to appear are Alexander the Great and Julius Cesar, two of the most important military leaders of antiquity, who now recognize the fragility and meaninglessness of such symbols of power as the scepter and crown that they had considered so important during their lives. "Where is the Martia legion?" asks Cesar. "Where are all the cohorts? Why don't they lift their swords to free their master from pain? Why haven't they employed their frightening spears against the Stygian enemy? Why don't they defend their leader? Alas, there is no help, no attendants for the king!" (Tuccius 2011, p. 266). Next comes Croesus, the embodiment of one who amasses wealth only to realize that death has reduced his riches to nothing; then Achilles, the great warrior, who finds himself now in chains; and finally, the last king of Assyria Sardanapalus, a symbol of decadence and self-indulgence, who remembers a life spent "playing the lyre, crowning my head with lilies and myrtle, taking my place at lavishly decked tables, [ ... ] hunting young women for love from all over the place", and now fears the effect of the "Stygian fire" over his "tender limbs" (Tuccius 2011, p. 266). ${ }^{24}$

The speeches of these condemned are structured similarly: a synthesis of their past lives and earthly accomplishments join with the awareness of the present situation, too late for repentance. They condemn the quest for power, riches and pleasure, all of which block the human aspiration for the divine good (Saulini 2002, p. 146). In other words, they indicate to the audience precisely which earthly attitudes and desires are more likely to condemn one to an eternity of suffering. Furthermore, by taking as spokesmen for sins famous characters from the historical or literary tradition (instead of generic sinners such as politicians or lechers, as he does in Christus patiens), Tuccio also encouraged those young minds that might have been fascinated by their studies of brave generals or wealthy kings, to reconsider the values transmitted during their history and literature classes, leading them instead not toward personal glory or riches or even the glory of the state, but rather toward ethical and religious values.

The concluding two speeches by the souls of the damned are possibly even more important for their polemical value in the Catholic Church's then contemporary historical situation: at the time, Spain was engaged in war against the Turks, and only a few years prior the Council of Trent had firmly condemned the Reformed Church (Saulini 2002, p. 147). The penultimate damned soul to introduce himself and his sins is Maometto [Muhammed], ${ }^{25}$ the founder of the Islamic religion which was at

24 Some of these characters also appear in Dante's Inferno. Alexander the Great is probably the tyrant pointed out by Nessus in Inf. XII, 107; Julius Cesar is encountered by Dante in Limbo (Inf. IV, p. 123), while Achilles is found amongst the sexual sinners (Inf. V, 65). The name of Sardanapalus, on the other hand, is mentioned in Dante's Paradiso as an example of debauchery (Par. XV, pp. 107-8).

25 In Dante's Inferno, Mohammed is found among the sowers of dissension (Inf. XXVIII, pp. 22-63). 
that time considered the ultimate enemy of Christianity. Like Jeremiah and Job before him, he curses the day he was born and every moment of his life, attributing infernal influence to the rules of the religion he created. The final character is Martin Luther, who defines his teaching against the sacred laws as foolish and false: "I am Luther. Ponder, friends, the ruin of your Luther. In what lands was Luther once unknown? What country did not hear the name of Luther? I who once preached so many heresies, I, the fool, who wanted to erase the traditions of the fathers and the rights of the Popes, I who wanted to cancel the sacred laws ... Now the infernal fire forces me to unlearn my foolish nonsense, to understand, and that is right" (Tuccius 2011, p. 268). Author Stefano Tuccio, in other words, has made good use of Dante's lesson here as well. By showing the recently deceased Martin Luther in hell, Tuccio takes his revenge against the most recent enemy of the Roman Church just as Dante had done against his political enemy Filippo Argenti, whom the poet reports encountering in the fifth circle of hell, or Pope Boniface VIII who was not dead yet in the year of Dante's fictional journey, but already had a place waiting for him in the eighth circle of hell. As distinct from Dante, however, Tuccio never shows the Church's historical and present enemies suffering the torments of hell; rather, he presents them at the moment of the final judgment, when the realization of the error of their ways and of the eternal punishment that follows is inevitable-again, the only moment in human history in which repentance is impossible. Tuccio's educational message to his audience resounds loud and clear: repent now, while you still can. Go and sin no more.

\section{Vincenzo Guiniggi's Ignatius Arma Mutans}

The second Jesuit play that stands out for its description of heaven and hell is Ignatius arma mutans by Vincenzo Guiniggi (1588-1653), performed in Rome in $1622 .{ }^{26}$ At first sight, the work appears to have unity of action, as it concerns Ignatius and his change from knightly arms to governing a sacred militia; and unity of place and time, as all the action occurs in Montserrat within one night and one day (Cao 1623, "Argomento abbreviato"). Despite this formal respect for the traditional unities of classic tragedy, however, the play also includes such dissonant scenes as an opening chasm, a pirate attack, the clash of armies, and a revelation of the heavens. The cast of characters include the Moors, young Indians, groups of Centaurs and Nereids, Neptune, a ghost, the king of Ethiopia, the good and the bad geniuses of Europe, Asia, Africa, America and the evil genius of Luther, arriving on a chariot through the air (Cao 1623, passim). Of the many events presented in this 5-act tragicomedy, again we find that some of the most powerful are the scenes set in heaven and hell, as well as those where angelic or diabolical characters intervene in earthly matters.

The main plot of the play refers to the night when Ignatius Loyola hung his sword and dagger at the altar of the Virgin Mary in her sanctuary of Montserrat. Such a portentous decision spurred great interest both in the infernal and heavenly spheres. As soon as Ignatius expressed his intention, the scene moves quickly from Montserrat to hell "represented by fiery mountains all around, and fires rolling beneath, and smoke and haze in the air" (Cao 1623, Act 2, sc. 5). There appear four demon tyrants representing the four corners of the earth; next an even larger mouth opens, and a deeper hell appears, from which the king of darkness and his court emerge. ${ }^{27}$ The devil declares that the world is in a period of transition. There could be great gains-or great losses. He asks his demons for news from each region of the world. As in Tuccio's Christus Iudex, Guiniggi uses the infernal environment to make both political and educational statements. Continuing the Jesuits' battle against reformist thought, the author at this point stages the flying demon from Germany, who reports with satisfaction

26 See Mertz et al. (1989, p. 193) for a very short biography of Guiniggi in English. The play has been printed in Latin; a detailed summary in Italian can be found in Cao (1623). Marii also summarizes the play in Italian, using the success and the request for repeated stagings of this five-act play in Latin as proof of the decadence of the educational system in Italy, since at the time when he was writing "even just the announcement of a play in Latin" would scare away anyone wishing to attend (Marii 1922, p. 491).

27 This scene may have been influenced by Canto IV of Torquato Tasso's Gerusalemme liberata (1581), which opens with a conclave of devils in hell, in itself a parody of the council of the gods of the Greco-Roman epic. 
that his pupil Martin Luther has escaped from the hands of the Catholics. ${ }^{28}$ The demon master of Luther recounts "the many schemes he [Luther] is plotting, the credit he has been obtaining, and the fact that his followers, whom he convinced to abandon the study of sciences, have brought their books into the public squares and set them on fire" (Cao 1623, Act 2, sc. 6). Though in keeping with chronological events, Guiniggi could not put Luther in hell as Tuccio did-given that the events of the play take place in 1522 and Luther did not die until 1546-still he manages to convey the idea that Luther was in fact the devil's pupil, and that his reform was the work of the devil.

If the demon from Germany helps Guiniggi in his polemic against the Reformation, the demon from Spain announces that Ignatius is presently in the Montserrat sanctuary, ready to devote himself to a mission to "convert the peoples, traverse Jerusalem, and enflame the World in the love of its Creator". At the news, "the king of hell is taken by great fear" and in fact all demons join him "in a desperate lament" (Cao 1623, Act 2, sc. 7). As at all costs Ignatius must be stopped from his plans, the evil genius of Spain brings under his command four minions: idolatry, atheism, heresy and national interest. This fourth evil minion takes the form of a soldier friend of Ignatius, who tries to convince him to resume his military life in defence of Spain; in fact, Ignatius "soon begins to feel the effects of the infernal spirit, experiencing an internal struggle of opposing ideas" (Cao 1623, Act 3, sc. 8). Thus, Guiniggi's educational message warns not only of the errors of religious heterodoxy, but also of one's false sense of duty towards civic life. Even military, political undertakings and nationalistic fervor, lie within the realm of Satan.

In the meantime, the celestial realm has shown interest in Ignatius as well. In scenes set in heaven, St Michael the Archangel explains to the Church that God is preparing for her a special protector. Since this protector, Ignatius, at that very moment is deposing his weapons in a church and devoting himself to the Blessed Virgin, St Michael asks that from the heavenly armory materials be selected for this man's new arms. The angels create for Ignatius an impenetrable armor, as well as a sword which takes strength, agility and splendor from lightening, and then give him a banner bearing Jesus' name. Eventually, Ignatius is taken up to the sky where he is shown the wonderful future achievements of his companions (in particular Francis Xavier, Luigi Gonzaga and Ignacio Azevedo). With their reference to books VI and VIII of Virgil's Aeneid, in which the hero Aeneas foresees his descendants, and receives divine weapons from his mother Venus, these scenes create a clear parallel between Ignatius the founder of the Jesuit order, and Aeneas the founder of Rome, as well as between the two heroes' civilizing mission throughout the world. In the final scene, the infernal monsters make one last desperate attempt, but Ignatius, now fortified with his heavenly weapons, scatters them. Rejoicing follows, not only on earth but also among the celestial spirits who carry Ignatius's name to heaven.

It is not difficult to see that this play, staged at the Jesuit Collegio Romano on the occasion of the festivities for the canonization of Ignatius of Loyola and Francis Xavier (16 March 1622), represents heaven and hell in order to show the extent of the influence that the Jesuits had on the history of the world. And although the play claims to be about that 24-h period in which the founder of the Society of Jesus made a solemn promise to leave his military career and become "a Captain in the sacred army devoted to the defence of the holy Church [ ... ] with no other goal in front of his eyes than the greater glory of his Lord" (Cao 1623, Act 5, sc. 9), it uses heavenly intervention to give Ignatius (in the play) and the spectators (in the Collegio Romano) a vision of the future development and world-wide achievements of the order. These visions of heaven and hell, however, are concerned with much more than the afterlife. Heaven and hell exist here; they influence life now. The message is clear: beware the friend who tries to convince you to do something that is not right. He could be a false friend-he could be the devil himself.

28 This section probably refers to the time when Martin Luther, after being excommunicated in 1520, stayed at Wartburg Castle and translated the New Testament into German. In his summary, Cao alludes to Luther's "retreat into his Patmos" (1623, Act 2, sc. 6), in reference to the island where John wrote the Book of Revelation. 


\section{The Salesians' Teatrino and Its Educational Purposes}

Christus Iudex and Ignatius arma mutans are but two examples of the educational and spectacular nature of Jesuit theatre. The Jesuits' use of theatre became such a distinctive and successful trait of their programme of education that it influenced other religious orders devoted to the education of youth as well: the Scolopians, for example, and the Barnabites, the Somaschans and the Salesians. The Salesians, in particular, stand out for their use of theatre as part of their educational programme because it was directed towards both young men and women, in a tradition that started from their origins and continues until today.

In 1859, the future saint Giovanni Bosco founded the Society of St Francis de Sales, commonly known as the Salesians of Don Bosco, an order devoted to the education of boys and young men of the most disadvantaged classes. A few years later, together with the future saint Maria Domenica Mazzarello, Don Bosco also founded the order of the Daughters of Mary Helper of Christians, also known as the Salesian sisters, which would instead be devoted to the education of girls and young women. ${ }^{29}$ Whereas the Jesuits were born to confront the social and religious fragmentation caused by the Protestant Reformation, the Salesians came about at the time when the Industrial Revolution had created a new urban lower class. The two Salesian orders were different from the Jesuits in as much as they worked with both young men and women, particularly of the lower classes, and not just in schools, but also in the so-called oratories, or youth centers where both students and young workers could spend their free time in a safe environment, away from the dangers of the streets. The Salesian orders were similar to the Jesuits, however, in that they confronted the challenges of their time with the use of theatre within their educational programs.

Together with study, work, play and physical activity, theatre was in fact, from the beginning, an integral part of Don Bosco's "preventive system" of education, which "rejected corporal punishment and strove to place youths in surroundings that removed them from the likelihood of committing sin" (Fardellone 1967, p. 714). Salesian educational theatre, however, did not solely attempt to prevent evil. It also endeavored to offer youth positive alternatives, supported by the continued presence of educators, who would associate with the young people both inside and outside the classroom (Lenti 2008, pp. 159-60). Moreover, in a recently united Italy, where less than 3 per cent of the population could read and write Italian, theatre was used not only to entertain, but also to transmit the Catholic message and stories even to the young and illiterate (Pivato 1993, pp. 446-48).

Like the Jesuits before them, the Salesians preferred single gender casts in their theatre for both moral and practical reasons: to avoid promiscuity among young people, and to facilitate rehearsal time, as schools, oratories and vocational centers in Italy were all single gender until the mid-1960s. Thus, dozens of Salesian priests and sisters took it upon themselves to create hundreds of single-gender plays or to adapt the classics for all-male or all-female casts, plays that would then be published in one of the many Salesian publishing venues and thus be spread in the Salesian schools and oratories throughout the country. Like Jesuit theatre, the educational message of Salesian theatre often addressed not only individual behaviors, but also societal and political concerns. As in the Counter-reformation years the Jesuits had included in their plays a condemnation of the enemies of the Church-Muslims as well as Protestants-in the 19th and 20th centuries the Salesians would now have to fight Protestantism, atheism and communism.

Other characteristics of Salesian theatre, however, mark it as significantly different from the Jesuit model: one is the avoidance of violent situations that might negatively affect young people. Don Bosco called his educational theatre teatrino (little theatre) to distinguish it from professional theatre and its often non-educational characteristics. Don Bosco's teatrino was meant to avoid situations that might "harden the hearts of the young people" or negatively affect their young sensibilities (quoted in Braido 1999). Again, as opposed to the spectacular nature of Jesuit theatre, Salesian theatre was characterized 
by its simplicity: the texts of the plays had to be suitable for the age and level of education of the young audience; costumes and settings could not require excessive expenses or create envy. Yet, in Don Bosco's mind, simplicity did not equate with poor planning or inadequate training: "I want [ ... ] performances that are simple, not showy. When do simple things ever displease the audience? Usually when they are poorly performed or when the taste of the spectators has been tainted by gaudy shows" (quoted in Stagnoli 1967-1968, p. 142).

A discussion of the development of Salesian theatre is beyond the scope of this article which will, instead, consider only a few plays written by Salesian authors for all-female casts in a specific period of time, that of the post-WWII years. This was a difficult time for Italian society, which was going through a period of extreme poverty after the close of the war and the end of the fascist dictatorial regime. But a positive sense of renewal also pervaded the era, supported by a popular referendum in which women voted for the first time, choosing a republic over the monarchy, and the consequent writing of a new democratic constitution. The Salesians' care of the youth was particularly important in these post-war years, when countless families had been torn apart and many children left orphan or at risk. Plays written by Salesian sisters and directed to young women, in particular, made clear that certain pastimes which became more popular or more accessible in the post-war years, such as cinema and dancing, were to be avoided. And what better way to frighten young people away from movie theatres or dance halls than to portray these places as the earthly homes of infernal creatures? ${ }^{30}$ In $\mathrm{La}$ vittoria del bene [The victory of the good] (1946), by sister Caterina Pesci (1906-1970), ${ }^{31}$ for example, the devil explains that "our representatives here on earth are three: bad friendships, bad books, [and] bad shows. Among the latter, cinema is the most powerful". It is through cinema, the devil boasts, that "we demons un-Christianize the world. From this school graduate murderers, suicides, adulterers, thieves, dissolutes, and betrayers of every law and faith. This is the temple of paganism, brutalization, superstition and idolatry" (p. 7). But movie theatres were not the only entertainment places which Salesian theatre described as inhabited by devils. In La rete di Satana [Satan's Net] by sister Lina Dalcerri (1902-1998), ${ }^{32}$ also of (Dalcerri 1946), the demons claim that their most effective way of conquering souls is through dance; dance-halls are their "kingdom". As a demon explains to his companions, "everything in here-from music and movements, to touches, gestures, words, looks, and attitudes-you need to make everything vibrate like the strings of an instrument, in an infernal note of malice and $\sin ^{\prime \prime}$ (p. 25). ${ }^{33}$

As might well be expected in educational theatre, the ending of the two plays sees the demons defeated and virtue triumphant. What is significant in both, however, is that the victory of good,

30 Other plays authored by Salesian sisters, on the other hand, staged guardian angels leading young women away from cinemas toward a life of purity, respect and church attendance. La vera figlia di Maria [The true daughter of Mary] (Pesci 1949) by Caterina Pesci consists of a dialogue between a girl and her guardian angel. Wishing to follow the Virgin Mary's example, the young protagonist declines her friends' offer to go to the cinema because a nun had said it was not a good film, and refuses to read the novel that one of them has left for her, sure that it would be of little value either. She throws it in the river, so that nobody will find it, and decides to read the Gospels instead. In cammino con gli angeli [Walking with angels] (Pesci 1955a) also by Caterina Pesci, portrays teenage Maria being tempted by a schoolmate who owns picture magazines, a radio and even a TV, and who has invited her to go by car to a meeting of a dubious nature. Maria's guardian angel warns her that those magazines are impure, that the television shows people who are not good; and Maria herself is aware that the association she has been invited to attend is led by godless people. Despite being sorely tempted by the novelty of the television, the protagonist ultimately manages to resist-thanks to the angel's inspiration-and even to convince two other friends not to yield to the temptation. Although no devils appear in this play, the underlying idea is that the bad press and the unnamed association are both manifestation of the devil's works.

31 Ossi (1990) provides an exhaustive biography of Sr. Pesci in Italian. For a short biography in English, see Cavallaro (2017, pp. 228-29).

32 See Cavallaro (2017, pp. 224-25) for a short biography of sister Dalcerri in English or Cavaglià (1999) in Italian.

33 The author of this play appears to be quoting Don Bosco's warning against dancing with a person of the opposite sex. Drawing on the authority of classical authors and the fathers of the Church, Don Bosco described dancing as "very dangerous for morality and, like theatre or even more than theatre, a school of unrestraint, which every good Christian must avoid" (Bosco 1868). Although he had once written that "dancing in itself is not sinful if practised with a person of the same sex" (Bosco 1868), in the deliberations of the second general chapter of the Daughters of Mary Helper of Christians he stated that "as a general rule, dancing should not be allowed, not even among girls" (Bosco 1886). 
announced already in the title of Pesci's play, is not obtained thanks exclusively to angelic intervention, but requires the active participation of the Salesian-educated young women on stage and among the audience. At the end of act 1 of La vittoria del bene, the audience witnesses how the angel on stage enlists young women who attend Salesian schools, to "renounce the evil shows, the forbidden books, the dangerous friendships" (Pesci 1946, p. 17), and promise to work as mothers and educators to raise their children or students according to the principles of the Catholic faith. La rete di Satana ends instead with the protagonist and her friends making a solemn vow in front of a statue of the Virgin Mary to never attend or participate in a dancing event. Thus, these Salesian educational plays have a double purpose: on the one hand, they are cautionary tales of the physical and spiritual dangers of dancing and going to the movies. On the other hand, the protagonists' vows pronounced on stage were meant to induce the members of the audience to renounce the temptation caused by dancing and cinema as well. In other words, the plays aim to affect a real conversion not only by scaring the young spectators off with demonic characters, but also by having the members of the audience join in the vow pronounced on stage by the young actresses. ${ }^{34}$

\section{The Afterlife as Staged in the Salesian Sister's Theatre}

In addition to these and the many other plays that stage angelic and demonic influence in our daily lives, Salesian sisters also used images of the after-world to reach their goal of educating and converting young women in the post-war years. One drama and two comedies in particular may give us a good idea of what sort of behavior might guarantee a young Italian Catholic woman in the 1950-1960s a place in heaven, purgatory or hell.

Interpretiamo Dante [Let's stage Dante] ${ }^{35}$ (1955b) by sister Caterina Pesci is a new take on Dante's depiction of the arrival of souls to the shores of purgatory, where the Roman orator Cato stands guard. During the course of the play, Cato interrogates six women's souls, choosing some to ascend to the mountain of purgatory and others to descend into eternal damnation, thus offering the young audience models with which to sympathize and others to avoid. The first three souls, Afrodisia, Russikà, and Abulìa, as their names suggest, were guilty of the sins of luxury, atheism and materialism, and cowardliness. The story of Afrodisia is quite appropriate for the young audience: heeding neither her mother nor her parish priest, at age 16 Afrodisia left school and ran away from home: "I told myself: why study and work? Why go to school every day? Someone whispered: 'You're beautiful. Come with me'" (p. 52). After a brief life of "flowers and jewels ... riches and sins" (p. 52) Afrodisia lost her youthful beauty, fell into financial ruin and ultimately committed suicide. Russikà, on the other hand, recounts how even though Italian, she always took the part of Russia, to facilitate Russia's conquest of her country. In all reality, she reveals, she did not care for anybody, not even when protesting for the rights of the workers. Furthermore, Russikà would badmouth priests, nuns and especially the Pope. Even her funeral "without priests ... red flags as far as the eye can see [... ] and ultimately the very flames of cremation" (p. 52) symbolized her loyalty to the devil. Russikà, the play explicitly states, is among those souls destined to hell with no possibility of redemption. As Cato explains: "You preached the theories of the godless people, you deceived the weak and the ignorant. [ ... ] you slandered God's ministers, you cursed the Pope, the Vicar of Christ, you betrayed your conscience and those of your compatriots. You've been excommunicated, you are more guilty than this miserable Afrodisia, who sought pleasure out of self-love. You ruined souls for the love of Satan ... . [ . . . ] Go! Like Afrodisia you are destined to hell, but your hell will be incommensurably harder than hers" (p. 55).

If Afrodisia and Russikà end up condemned for what they did, Abulìa is convicted for what she did not do: she did not defend the Pope when others blasphemed him; and she did not speak

34 On the inspirational effect of Salesian educational theatre on both actresses and audiences, see Cavallaro (2011), in particular page 37.

35 The Italian title plays on the two meanings of the verb "interpretare" as both to stage and to interpret. 
up against the godless people. While the word "communism" or "communists" is never specifically pronounced in this play, there is no doubt as to whom Abulìa should have stood up to. In the end, the demons come on stage and drag the screaming souls away toward eternal damnation. In particular Russikà, who during life insisted that nothing exists after death, exits the stage cursing the heretics, the godless and even herself.

The three women who will be allowed to proceed toward the mountain of purgatory, on the other hand, all bear names which refer to the Virgin Mary: Maria, Assunta and Concetta. Maria's sins are sculpted on her forehead: "frivolity, vanity, disobedience and laziness" (Pesci 1955b, p. 58); Assunta for a while was swayed by godless heresy, but later abandoned the error of her ways; Concetta, though a good wife who raised five children and died while reciting the rosary, still counted among her sins impatience, gossip and the occasional lie to her husband. These three souls are allowed to be purged of their sins and will eventually be admitted to the presence of God.

The choice of the shores of purgatory as a setting for a judgment play differentiates Salesian from Jesuit theatre. A shore with a dantescan mountain backdrop would have been easier to create than the infernal abyss. Moreover, as Salesian theatre aims to avoid violence and negative images, the play never actually shows the torments that await the sinners in hell. On the other hand, like Christus Iudex, Interpretiamo Dante displays the moment in which repentance is no longer possible. Again, as in Jesuit theatre, the Salesian play refers to both the personal and the political; on the level of personal behavior, it condemns frivolity and sensuality, shows that repentance in this life is possible, and presents imperfect but still forgivable role models of wives and mothers, who pray the rosary and travel to Rome to see the Pope. On the political level, the play attacks both the supporters of the "godless heresy" - published in 1955, the play perfectly stages the ideological division of Italy during the cold war-and those who do nothing to stop it. Like Dante and the Jesuit playwrights, sister Caterina Pesci condemns these current enemies of the Church to hell. But perhaps even more interestingly, sister Pesci also condemns Dante if not to hell, at least to many years in purgatory. At the end of Caterina Pesci's play, Cato reveals that Dante's spiteful treatment of many popes, especially Boniface VIII, as mentioned earlier, destined him to a very long time in purgatory, from which he emerged only recently by the direct intervention of the Virgin Mary, to whom he was devoted. In fact, the play ends with Cato revealing that Dante, from heaven, is now smiling down upon this new interpretation of his work, and Pope Boniface VIII is happy as well.

In her comedy Davanti a San Pietro [In front of St. Peter], which stages several souls who arrive to the gates of heaven to be judged by St. Peter, Gina Saffirio (1909-1994) ${ }^{36}$ treats the reckoning of sin in a much lighter way. Published in 1962, this play also contains male characters, who may or may not have been acted by young women anyway. However, the presence of both men and women among the recently departed souls also allows us to see what kind of sins were typically attributed to each gender.

The setting is simple: a desk with an enormous book and a chair; the audience is not allowed to see the delights of heaven. St Peter, distinguished as so often in the Christian tradition by a large set of keys, ${ }^{37}$ welcomes the recently arrived souls, checks his book, and decides their destiny. Spoiler alert: all the souls will go to purgatory—but for what sins? The first is a 14-year old girl—the very representative of the typical spectator. Apparently, young Marisa has devoted more time to outings than homework, has been distracted at mass, has sometimes mistreated her younger siblings, and has not always respected her mother. Another young woman, on the other hand, is guilty of far worse sins, as she was hoping to smuggle into heaven several copies of the glossy magazines Bolero Film and Grand Hotel - the most popular fotoromanzi of the times. In addition to international and local film star gossip, these "photonovels" or "photomagazines", a genre created in Italy in the post-World War II era, consisted of love stories represented by photos, with lines of dialogue as in comic strips written in

36 Gina Saffirio was a primary school teacher in a village of the Piedmont region who published her educational plays in the Salesian theatre magazine for girls.

37 Mt 16: 19. 
speech balloons. These weekly publications, aimed almost exclusively at a female audience, became wildly popular in the post-war years among the lower socioeconomic classes, as they "filled a void left by both the high culture of literature and the mass culture of the cinema" (Garbin 2007, p. 769). Thirdly, a widow, who expects to be accepted into heaven because of the many charities to which she contributed, is accused by St Peter of doing charity work only "to be seen" or "to show off her clothes" (Saffirio 1962, p. 56); she too is in need of purification.

Purgatory is also the destination for two young men who have kept bad company, attended wild parties and watched excluded films; a drunkard who was only saved by a final confession arranged by his wife; and finally, to St. Peter's great surprise, even a shopkeeper whose accounting was not always honest. Bearing in mind that spectators in the Salesian plays would include not only other members of the school or oratory (hence the two young women's souls, guilty of superficial readings and disobedient attitude), but also the parents (hence the drunk and the dishonest shopkeeper), benefactors (hence the widow) and sometimes young men of the community who may have been interested in the young women on stage and in the audience (hence the movie-going couple of friends), one can see that the educational message of this play extended to the entire Salesian community.

Both Interpretiamo Dante and Davanti a S. Pietro are set on the threshold of purgatory or heaven. Both are plays in which souls are judged and sent on their way, either to hell or to purgatory; and both give the audience a moral compass on which behaviors to avoid. One final play, on the other hand, gives us a glimpse into heaven itself, a glimpse of what heaven might look like and the sort of people who get there, thus providing the audience with the best of role models to follow.

If in Gina Saffirio's Davanti a S. Pietro the protagonist St Peter had complained of the time it took to judge each arriving soul, the two doorkeeper angels who are acting as St Peter's substitutes in Gran festa in Paradiso [A grand celebration in Heaven] (Fornara 1965) by sister Flora Fornara (1902-1971) ${ }^{38}$ complain of the enormous amount of people admitted into heaven since Don Bosco's arrival: "teenagers, priests, nuns, girls and boys, men and women with their badge of 'supporter', as well as young women, young men, adults, seniors, mothers, countless grandmothers, and all those with an 'alumnus' or 'alumna' badge" (p. 109), in addition to other individuals with no badge whatsoever who need only say 'Salesian benefactor' to simply waltz in. The other problem with this Salesian community in heaven is that they are awfully noisy: they cheer, laugh, sing and shout just like they did on earth, perhaps bothering that corner of heaven which belongs to the Trappist and Carthusian monks. Such a depiction of a Salesian heaven brings to mind the Simpsons episode "The Father, the Son and the Holy Guest Star" (season 16, episode 21) in which Marge imagines Protestant heaven as an aseptic, snobbish place of limited entry, as opposed to the several branches of Catholic heaven, where Hispanics dance, Irish drink and fight, and Italians sit around a table, eat, drink and kiss. In other words, according to Salesian educational theatre, what is needed to enter heaven? Basically, as long as you are part of the Salesian community, you will be just fine. Such an inclusive vision of heaven may well have been reassuring for the play's audience, made up most probably of students, families, alumni and benefactors, and would have confirmed the sense of belonging to a special group, already predestined to a joyous afterlife thanks to the special place that Don Bosco and St Maria Mazzarello have acquired in heaven for themselves and their community.

\section{Conclusions: Repent. Go and Sin No More}

A few conclusions can be drawn from these examples of 16th and 17th century Jesuit and 20th century Salesian theatrical representations of heaven and hell.

First, of course, there was the educational goal: although the Jesuit theatricality would have been much more elaborate than the home-spun Salesian sets and costumes, the basic idea was the same. Look at the beautiful, winged, triumphant angels; consider the ugly, horned, screaming demons; listen

38 For a short biography of sister Fornara, see Cavallaro (2017, p. 225). 
to the life experiences of those who will be whisked upwards by angels into heaven, and ponder the inglorious tales of those who will be dragged down by demons into eternal suffering. Then choose. Which role model will you follow? The time to make that choice is now.

Both congregations, in fact, insist that conversion happen now. Now you can still recognize the error of your ways; now you can still change. There will come a time, however, as Jesuit priest Stefano Tuccio staged in Christus Iudex, or as Salesian sister Caterina Pesci demonstrated in Interpretiamo Dante, when repentance will no longer be possible. Wait no longer to make that confession, pray that rosary, pay attention in church or cease coveting riches and glory. Repent now. ${ }^{39}$

The sins to avoid, on the other hand, varied somewhat. The 16th and 17th century Jesuit school students were educated toward lives of civic involvement or religious commitment. Thus, Tuccio chose famous examples of influential men condemned to hell because of their thirst for power, riches or self-indulgence. And Jesuit priest Vincenzo Guiniggi showed that not only idolatry, atheism and heresy, but also sometimes even nationalism or a forced sense of civic duty may be inspired by the devil, hence stressing once again the Jesuits' model of life devoted not to the greater glory of individuals, kings or nations, but rather to the one and only God.

The young women who received an education in the Salesian schools and oratories in the 1950s, on the other hand, were mostly destined to their mission of wives and mothers, perhaps educators of the younger generations. Purity and faith were essential to those roles. Consequently, the Salesian sisters' educational plays stress the importance of avoiding sensual temptations that may be found in the darkness of a movie theatre, in the physical promiscuity favored in dance halls, in the romantic reveries portrayed on the pages of fotoromanzi.

Despite the variance of the sins, however, the educational plays of both congregations helped their audiences to identify as works of the devil those temptations to which an educated young man in the 17th century and a lower-class young woman in the mid-20th century could be subject. And for both there was an urgency in their message: Repent. Now. And avoid the near occasion of sin.

There are other common characteristics which translate into other common goals as well: by placing their enemies in hell, both the Jesuits and Salesian added a polemic, propagandistic layer to their educational plays, showing the eternal punishment that awaits those who in the counter-reformation era followed Martin Luther, or in 1950s Italy aligned themselves with the godless communists. As for themselves, both the Jesuits and the Salesians theatrically show their founders Ignatius Loyola, Francis Xavier, Don Bosco and Maria Mazzarello as part of the celestial realm, and thus able to support the members of their community in their quest for heaven. In other words, the scenes set in heaven create not only angelic visions, but also promote the congregations themselves-they now have their own saints in paradise-as well as a sense of belonging for the spectators, who find themselves well represented among the characters onstage.

Of course, the tradition of setting educational plays in the afterlife is not exclusive to Catholic Italy and did not die in the 1950s. In fact, that tradition continues to be very strong even today among evangelical groups who tour local churches to affect conversions among their spectators with their visions of heaven and hell. The drama Heaven's Gates, Hell's Flames, for example, created by Reality Outreach Ministries, according to their website, "is an evangelistic outreach tool that has been used to save hundreds of thousands of lives over the last 40 years, [performed by] 26 teams in over 20 countries". ${ }^{40}$ The purpose of this 21 st century American performance showing heaven and hell-like those of the 17th century or 1950s Italy—remains the same: to bring about conversions while involving the entire community. In other words, the message of these plays set in the afterlife and sponsored by religious groups-be they Jesuits, Salesians or evangelicals, from the 17th, 20th or 21st centuries-remains a part of a very traditional Judeo-Christian call: repent. Go and sin no more.

39 This is also the most basic message of the Deuteronomic Historian (Dt 30: 15-20).

40 https://realityoutreach.org/. 
Funding: This research received no external funding.

Conflicts of Interest: The author declares no conflict of interest.

\section{References}

Black, Robert. 2007. Education and Society in Florentine Tuscany: Teachers, Pupils, and Schools, c. 1250-1500. Boston: Brill.

Bosco, Giovanni. 1868. Il cattolico provveduto nelle pratiche di pietà. Torino: Tipografia dell'Oratorio di S. Francesco de Sales. Available online: http://www.donboscosanto.eu/Scritti/don_bosco-il_cattolico_provveduto_per_le_ pratiche_di_pieta.html\#A069001209 (accessed on 7 December 2011).

Bosco, Giovanni. 1886. Deliberazioni del Secondo Capitolo Generale delle Figlie di Maria SS. Ausiliatrice tenuto in Nizza Monferrato nell'agosto del 1886. Available online: http://www.donboscosanto.eu/Scritti/don_boscodeliberazioni_del_secondo_capitolo_generale_delle_figlie_di_maria_ss._ausiliatrice.html\#A044000186 (accessed on 6 December 2011).

Braido, Pietro. 1999. Prevenire, non reprimere. Il sistema educativo di don Bosco. Rome: LAS Editrice. Available online: http://www.donboscoland.it/articoli/articolo.php?id=3873 (accessed on 20 October 2011).

Breitenstein, Mirko. 2018. Living with Demons: The Horror of the Beyond as a Challenge of Life in the Middle Ages. In Experiencing the Beyond: Intercultural Approaches. Edited by Gert Melville and Carlos Ruta. Oldenbourg: De Gruyter, pp. 121-37.

Cao, Girolamo. 1623. Soggetto d'Ignatio in Monserrato, ouero Mutatione d'armi. Rome: Zannetti.

Cavaglià, Piera. 1999. Lina Dalcerri: Una sintesi vitale di scienza e spiritualità. Rivista di Scienze dell'Educazione 37: 229-58.

Cavallaro, Daniela. 2011. Salesian Theatre for Young Women in post-World War II Italy. Ecumenica 4: 25-50.

Cavallaro, Daniela. 2017. Educational Theatre for Women in Post-World War II Italy: A Stage of Their Own. Basingstoke: Palgrave.

Cohelho, Victor Anand. 1997. Kapsberger's Apotheosis ... of Francis Xavier (1622) and the Conquering of India. In The Work of Opera. Genre, Nationhood, and Sexual Difference. Edited by Richard Dellamora and Daniel Fischlin. New York: Columbia University Press, pp. 27-48.

Conrod, Frédéric. 2010. Meditating Hell: An Image of Satan from Loyola's Spiritual Exercises. In Death: The Case of the Hispanic Early Modern World. Edited by John Beusterien and Constance Cortez. Minneapolis: University of Minnesota Press, pp. 89-105.

Dalcerri, Lina. 1946. La Rete di Satana. Purezza e martirio (Ballo e rispetto umano). Colle Don Bosco: Libreria Dottrina Cristiana, pp. 3-38.

Dies Irae-Day of Wrath. 1998. Available online: http://www.preces-latinae.org/thesaurus/Hymni/DiesIrae.html (accessed on 7 September 2018).

Fardellone, Emil Francis. 1967. Bosco, John, St. In New Catholic Encyclopedia. Vol. II. New York: McGraw-Hill Book Company, pp. 714-15.

Filippi, Bruna. 2001. Il teatro degli argomenti: gli scenari seicenteschi del teatro gesuitico romano: catalogo analitico. Rome: Institutum Historicum S.I.

Fornara, Flora. 1965. Gran festa in Paradiso. In Carosello Festivo. Rome: LES, pp. 108-13.

Francis, Pope. 2014. General Audience. Available online: http://w2.vatican.va/content/francesco/en/audiences/ 2014/documents/papa-francesco_20141126_udienza-generale.html (accessed on 8 September 2018).

Gallo, Anne-Sophie. 2018. Jesuit Theater. In The Oxford Handbook of Jesuits. Edited by Ines G. Županov. Oxford: Oxford University Press. [CrossRef]

Garbin, Barbara. 2007. Fotoromanzo. In Encyclopedia of Italian Literary Studies. Edited by Gaetana Marrone. London and New York: Routledge, pp. 769-70.

Grendler, Paul F. 2014. Jesuit Schools in Europe. A Historiographical Essay. Journal of Jesuit Studies 1: 7-25. [CrossRef]

Haraguchi, Jennifer. 2009. Reinforcing Rules of Conduct in Eleonora Ramirez di Montalvo's Rappresentazione delle virtù e de' vizi. In Scenes from Italian Convent Life: An Anthology of Theatrical Texts and Contexts (15th-17th Centuries). Edited by Elissa Weaver. Ravenna: Longo Editore, pp. 171-92.

Hughes, Robert. 1968. Heaven and Hell in Western art. London: Weidenfeld \& Nicolson. 
Ignatius of Loyola. 1991. The Spiritual Exercises and Selected Works. Edited by George E. Ganss. New York: Paulist Press.

Ignatius of Loyola. 2006. Letters and Instruction. Edited by Martin E. Palmer, John W. Padberg and John L. McCarthy. St. Louis: Institute of Jesuit Sources.

Isgrò, Giovanni. 2015. La scena evangelizzatrice: il teatro dei missionari nelle colonie spagnole del centro e Sud America. Bari: Pagina.

Lapsley, John. 2018. Holy Smoke! Fires of Hell Extinguished. Otago Daily Times. April 18. Available online: https://www.odt.co.nz/opinion/holy-smoke-fires-hell-extinguished (accessed on 8 September 2018).

Lenti, Arthur J. 2008. Don Bosco: History and Spirit. In Don Bosco Educator, Spiritual Master, Writer and Founder of the Salesian Society. Rome: LAS, vol. 3.

Marii, Gaspare. 1922. Un dramma latino per la canonizzazione di s. Ignazio al Collegio Romano. La civiltà cattolica 73: 491-508.

McCabe, William H. 1983. An Introduction to Jesuit Theatre. Edited by Louis Oldani. St. Louis: Institute of Jesuit Sources.

McFarland, Ian A. 2011. Charism. In Cambridge Dictionary of Christian Theology. Edited by Ian A. McFarland, David Fergusson and Karen Kilby. Cambridge: Cambridge University Press. Available online: fromhttp://ezproxy.auckland.ac.nz/login?url=https://search.credoreference.com/content/ entry/cupdct/charism/0?institutionId=181 (accessed on 20 August 2019).

Medieval Drama in Europe. 2000. The Cambridge Guide to Theatre, 2nd ed. Edited by Martin Banham. Cambridge: Cambridge University Press. Available online: http://ezproxy.auckland.ac.nz/login?url=https://search. credoreference.com/content/entry/cupthea/medieval_drama_in_europe/0?institutionId=181 (accessed on 19 September 2018).

Mertz, James J., Josef I. Jsewijn, and John P. Murphy. 1989. Jesuit Latin Poets of the 17th And 18th Centuries: An Anthology of Neo-Latin Poetry. Wauconda: Bolchazy-Carducci.

O'Malley, John W. 2013. Saints or Devils Incarnate? Studies in Jesuit History. Boston: Brill. [CrossRef]

Oldani, Louis J., and Victor R. Yanitelli. 1999. Jesuit Theater in Italy: Its Entrances and Exit. Italica 76: 18-32. [CrossRef]

Ossi, Maria. 1990. Una donna di futuro. Caterina Pesci. Rome: Istituto Figlie di Maria Ausiliatrice.

Paradise Polled: Americans and the Afterlife Blog. 2015. Roper Center. June 15. Available online: https: //ropercenter.cornell.edu/paradise-polled-americans-and-afterlife (accessed on 19 September 2018).

Parole del Papa a Scalfari: non una fedele trascrizione. 2018. Vatican News. March 29. Available online: https://www.vaticannews.va/it/papa/news/2018-04/papa-francesco-eugenio-scalfari-sala-stampasanta-sede.html (accessed on 7 September 2018).

Pesci, Caterina. 1946. La vittoria del bene. In Trionfo di gigli (Cinema e purezza). Colle Don Bosco: Libreria Dottrina Cristiana, pp. 3-29.

Pesci, Caterina. 1949. La vera figlia di Maria. Teatro delle Giovani 2: 48-54.

Pesci, Caterina. 1955a. In cammino con gli angeli. Teatro delle Giovani 9-10: 51-59.

Pesci, Caterina. 1955b. Interpretiamo Dante. Teatro delle Giovani 3-4: 50-60.

Pivato, Stefano. 1993. Don Bosco and the popular theatre. In Don Bosco's Place in History. Acts of the First International Congress of Don Bosco Studies (Salesian Pontifical University-Rome, 16-20 January 1989. Edited by Patrick Egan and Mario Midali. Rome: LAS, pp. 439-49.

Prosperi, Adriano. 2015. The Two Standards. The Origins and Development of a Celebrated Ignatian Meditation. Journal of Jesuit Studies 2: 361-86. [CrossRef]

Saffirio, Gina. 1962. Davanti a San Pietro. Teatro delle Giovani 3: 54-60.

Sani, Roberto. 2009. Ad Maiorem Dei Gloriam. Istituti Religiosi, Educazione e Scuola Nell'italia Moderna e Contemporanea. Macerata: EUM-Edizioni Università di Macerata.

Saulini, Mirella. 1999. Un nuovo manoscritto del 'Christus Iudex' del padre Stefano Tuccio. Giornale storico della letteratura italiana 574: 196-221.

Saulini, Mirella. 2002. Il Teatro di un Gesuita Siciliano: Stefano Tuccio S.J. Rome: Bulzoni.

Scalfari, Eugenio. 2018. Il Papa: È un onore essere chiamato rivoluzionario. La Repubblica, March 28.

Schnitzler, Henry. 1952. The Jesuit Contribution to the Theatre. Educational Theatre Journal 4: 283-92. [CrossRef]

Selwyn, Jennifer D. 2004. A Paradise Inhabited by Devils. The Jesuits' Civilising Mission in Early Modern Naples. Aldershot: Ashgate. 
Stagnoli, Saverio. 1967-1968. Don Bosco e il teatro educativo salesiano. In Eco degli Oratori. Rome: LAS.

Tuccius, Stephanus S. J. 2011. Christus Nascens. Christus Patiens. Christus Iudex. Tragoediae. Translated and Edited by Mirella Saulini. Rome: Institutum Historicum Societatis Iesu.

Weaver, Elissa B. 2002. Convent Theatre in Early Modern Italy: Spiritual Fun and Leaning for Women. Cambridge: Cambridge University Press.

Wetmore, Kevin J., Jr. 2016. Jesuit Theater and Drama. Oxford: Oxford University. [CrossRef]

Willan, Philip. 2018. Pope Francis 'Abolishes Hell', Saying Souls of Unrepentant Sinners Will Simply Disappear. The Times. March 29. Available online: https://www.thetimes.co.uk/article/pope-francis-abolishes-hellsaying-souls-of-unrepentant-sinners-will-simply-disappear-pwlv61667 (accessed on 8 September 2018).

Zanlonghi, Giovanna. 2004. Il teatro nella pedagogia gesuitica: una 'scuola di virtù'. In I Gesuiti e la Ratio Studiorum. Edited by Manfred Hinz, Roberto Righi and Danilo Zardin. Rome: Bulzoni, pp. 159-90.

Zanlonghi, Giovanna. 2006. The Jesuit Stage and Theatre in Milan during the Eighteenth Century. In The Jesuits II: Cultures, Sciences, and the Arts, 1540-1773. Edited by John W. O'Malley, Gauvin Alexander Bailey, Steven J. Harris and T. Frank Kennedy. Toronto: University of Toronto Press, pp. 530-49.

(C) 2019 by the author. Licensee MDPI, Basel, Switzerland. This article is an open access article distributed under the terms and conditions of the Creative Commons Attribution (CC BY) license (http://creativecommons.org/licenses/by/4.0/). 
Article

\title{
Gertrude Stein and the Metaphysical Avant-Garde
}

\author{
Dana Tanner-Kennedy
}

Department of Drama, University of Alberta, Edmonton, AB T6G 2R3, Canada; dana.tanner.kennedy@gmail.com

Received: 16 September 2019; Accepted: 12 March 2020; Published: 25 March 2020

\begin{abstract}
When American metaphysical religion appears onstage, it most often manifests in the subject matter and dramaturgies of experimental theater. In the artistic ferment of the 1960s and 1970s counterculture, theater-makers looked both to alternative dramaturgies and alternative religions to create radical works of political, social, and spiritual transformation. While the ritual experiments of European avant-garde artists like Artaud and Grotowski informed their work, American theater-makers also found inspiration in the dramas of Gertrude Stein, and many of these companies (the Living Theatre and the Wooster Group, most notably) either staged her work or claimed a direct influence (like Richard Foreman). Stein herself, though not a practitioner of metaphysical religion, spent formative years in Cambridge, Massachusetts, at Radcliffe under the tutelage of William James. Cambridge, at the turn of the twentieth century, was a hotbed of spiritualism, theosophy, alternative healing modalities, and James, in addition to running the psychology lab in which Stein studied, ran a multitude of investigations on extrasensory and paranormal phenomena. This article traces a web of associations connecting Ralph Waldo Emerson, Transcendentalism, and liberal Protestantism to Gertrude Stein and landscape dramaturgy to the midcentury avant-garde, the countercultural religious seeking of the 1960s and 1970s, and the Off-Off-Broadway movement.
\end{abstract}

Keywords: American avant-garde theater; Gertrude Stein; metaphysical religion

"Is life worth living? Yes, a thousand times yes when the world still holds such spirits as Prof. James", wrote a 21-year-old Gertrude Stein in ardent acclamation of her mentor, the eminent American psychologist and philosopher William James (Ruddick 1990) ${ }^{1}$. Stein's exuberant tribute seems to have been a response to the eponymous question James posed in one of his most famous essays, his 1895 lecture "Is Life Worth Living?", which dwelled not on the psychological concepts that Stein, a student at Radcliffe, studied in his classrooms and laboratories (the influence of which on her experimental prose style has been well-documented by critics and scholars). Rather, it presented thoughts on James's other chief field of experimentation and study: religion. The lecture described a relationship between the spiritual and natural worlds, defining religion as belief "that the so-called order of nature that constitutes this world's experience is only one portion of the total Universe, and that there stretches beyond this visible world an unseen world" which gives meaning to mundane reality (James 1895, p. 15). James argued for the power of "maybe" and the necessity of religious possibility, for a leap over the abyss towards which meaninglessness tempts in favor of an assent to the sacred, a yes to belief, a heroic burst of faith in the unseen order.

Whatever captivated Stein in James's talk was not unusual in his writing. Before composing his foundational text on religion, The Varieties of Religious Experience (1902), James rehearsed many of his ideas in the lecture hall and the lab. In doing so, he inevitably exposed his students to the religious ideas that influenced his own, chief among them the works of the minister, poet, and philosopher

1 Quoted in Lisa Ruddick's Reading Gertrude Stein: Body, Text, Gnosis. 
Ralph Waldo Emerson, a key architect of Transcendentalism, a uniquely American philosophy that influenced many of the metaphysical religions to which James devoted years of research. Within these later generations of spiritual practices could be found the DNA of Emerson's gospel of radical individualism, esoteric correspondences, continual revelation, personal spiritual discovery, Romantic nature, salutary solitude, and language's creative force.

While Stein eventually moved away from the direct influence of James, she remained steeped in his language and ideas, and traces of his religious experiments, as well as of Emerson, continued to arise in her work ${ }^{2}$. Stripping this language of its metaphysical overtones in favor of a deliberate vagueness, Stein could allude to these former meanings without directly referring to them (Poirier 1992). The result is that Gertrude Stein, despite her avowed secularism, is the foremost playwright of metaphysical America. And though Ulla Dydo, Marc Robinson, Joseph Cermatori, and Rebecca Kastleman, among others, have observed Stein's fascination with Catholicism and saints, less attention has been paid to metaphysical religion as a dimension of Stein's work or its ripple effect through the American avant-garde.

Stein's preoccupation with the workings of the mind, her embrace—knowingly or not—of a theory of correspondences to describe her personal metaphysics, and her attention to attention itself, to as Kate Davy put it, the "evolution of consciousness," locate her squarely within the primary obsessions of American metaphysical religion (Davy 1978, p. 124). Stein's use of the word "meditation" to describe her writing process reflects the larger late-nineteenth century cultural fascination with contemplative practice and "mental hygiene." Her turn to landscapes and nature stems in part from the influence of Transcendentalist thinkers. And her elevation of the artistic masterpiece as humanity's highest goal and achievement represents Stein's revision of Emersonian ideals. Metaphysical resonances persist in Stein's theories, in her plays, and in her dramaturgy, even when her work is later borrowed and remade by artists of the burgeoning American avant-garde of the 1960s and 70s.

What follows here are the seeds of an intellectual genealogy of the American avant-garde with particular attention paid to Stein and the shifting religious landscapes of metaphysical religion. As Sarah Bay-Cheng suggested: "the history of the avant-garde is perhaps best evaluated as an intricate web of overlapping and conflated influences, Stein being only one of them" (Bay-Cheng 2004, p. 119). Presented here are some of the primary strands of that web, or to offer another metaphor, a constellation of ideas that suggest a larger picture rather than propose a string of direct causal relationships. Within this constellation, Stein proves to be not only a major influence on the generations of American avant-garde that follow her, but she also provides a link to an earlier generation of metaphysical thought in America. By tracing Gertrude Stein's relationship to metaphysical religion, we can also begin to trace how theatrical alternatives to a dominant strain of realistic drama have grown up side by side with spiritual alternatives to the dominant faiths of evangelical and denominational religion. Stein's language echoes metaphysical discourse by retaining fragments of something beyond the material, hovering between belief and unbelief, haunted, teasing, suggesting.

\section{Metaphysical Religion}

In the ever-unfolding story of religiously-inflected theater created for secular American stages, scholarly narratives may neglect to focus on the presence of metaphysical religion. Scholars and

2 In Reading Gertrude Stein: Body, Text, Gnosis, Lisa Ruddick argues that Stein's radical innovations encode her process of self-definition against James and the entire nineteenth century, which he represented. In Poetry and Pragmatism, an exploration of the thematic and syntactic links between Emerson and a handful of modern American writers-including Robert Frost, Wallace Stevens, and Stein-Richard Poirier, calls William James the "point of transmission" linking Emerson to the rest, and proposes that all, in spite of their "democratic impulse", share "a recognition that language, if it is to represent the flow of individual experience, ceases to be a instrument of clarification or clarity and, instead, becomes the instrument of a saving uncertainty and vagueness". Poirier casts Emerson as a kind of proto-postmodern, citing Emerson's recognition that "every text is a reconstruction of some previous texts" and that language both "creates structures we can believe in" while simultaneously creating "gaps in those structures, gaps in what it only pretends to have settled". This skepticism particularly manifests in "matters of belief". Poirier traces this skepticism through Emerson, James, and Stein, and shows how Emerson's progeny continually revised and reformed his ideas, each through his or her own unique genius. 
critics often limit discussions of religion on secular stages to works that appear overtly in dialogue with a religious context: i.e., Jesus Christ Superstar, to offer an example from some of the decades mentioned here, or Lucas Hnath's The Christians and Joshua Harmon's Bad Jews, as examples from our more recent moment. Additionally, scholarship tends to focus on works in dialogue with various Christian traditions as well as on Judaism to a lesser degree. But as Catherine Albanese has argued, metaphysical religion represents a significant vein of spiritual practice within the story of American religion. A notable exception in this body of scholarship is Edmund Lingan's The Occult Revival and Its Theatrical Impulses (2014), which explores drama and performance in dialogue with a variety of traditions that fall under the larger banner of the term "metaphysical". Lingan's American examples, however, were primarily performed within ritual contexts and utopian spiritual communities rather than for heterogeneous audiences on secular stages. By unearthing metaphysical resonances in Stein's work and the work of her later admirers, metaphysical religion finds a more central place in the larger story of religion on professional stages.

Defining metaphysical religion requires its own complicated web of associations. In her 2001 book The Republic of Mind and Spirit, Catherine Albanese offered a complimentary narrative to the evangelical and denominational stories of American religion by tracing a third strand-a "combinative" religious practice she called "metaphysical" (Albanese 2007, p. 21). In 2005, Leigh Eric Schmidt argued in Restless Souls that those who today identify as "spiritual but not religious" come from a documentable tradition dating to the nineteenth century's shift towards religious liberalism-a shift that began ostensibly with the Transcendentalists. Both show how this non-creedal spirituality espoused religious ecumenism, inclusivity, and individual mystical access to the divine. Whether labeled "mysticism," "metaphysical religion," or "spirituality," this American religious tradition is "excitedly eclectic, mystically yearning, perennially cosmopolitan" and offers a liberal, progressive, left-leaning spiritual counterweight to orthodox religions and the Christian Right (Schmidt 2005, p. 6).

While Schmidt focused on the shift towards liberalism in the nineteenth century, Albanese's story of metaphysical religion in America began in the Hermetic and vernacular magical traditions of Europe and traced its reformulation in the New World after contact with African and Indigenous traditions. She followed the word "metaphysics" from a nineteenth-century "catholicity of mind and spirit signified, especially, by an openness to Asia and an embrace of South and East Asian religious ideas and practices" through the twentieth-century shift towards "a self-styled name for Americans who understood themselves as seekers on a 'spiritual' path" (Albanese 2007, p. 12). Schmidt focused on the trajectory of the American religious "seeker" or "mystic," from the Transcendentalists along the open road of Whitman through what is often referred to today as "self-care"—cultivating a calm, centered inner life within the stresses of the workaday world. Beginning with Emersonian individualism and Thoreauvian solitude, Schmidt forged a path through the search for a universal mystical religion and the burgeoning vogue for meditation.

To make Stein's metaphysical resonances legible requires a return to Albanese's definition of metaphysical religion, which, above all, is concerned with "mind and its powers". Albanese explains, "Mind, in short, is about consciousness and all that derives from and returns to it-with emphasis ever on the mental awareness by which humans interact with their environments." Mind covers a range of experiences and expressions: "poetry and intuition"; so-called "psychic" activities like "clairvoyance and telepathy"; the experience of "altered states of attention such as trance and meditation"; mind even "translates to action and material transformation". The metaphysics of mind forms a nexus between interiority and the physical world that ground metaphysical religion. In the centuries of history Albanese traverses, this concept of mind remains continually at the center, in practices as varied as mental healing, meditation, and channeling (ibid, p. 13).

Albanese also points to the ways in which American metaphysical religion recapitulates the "ancient cosmological theory of correspondences between worlds" and posits an equivalence between the macrocosmic "world of divinity, Nature, or the metaphysically favored eternal or collective Mind" and the microcosmic "human (and sometimes natural) world and/or mind". Macrocosm and 
microcosm "could be described as made of the same stuff", like each other "in all things except scale" (13-14). Albanese's reconstruction of the long lineage of these correspondences shows how each proffered a unique but analogous set of terminology to describe this macro/microcosmic relationship, from Transcendentalism to Christian Science to New Age philosophy.

The relationship between the macrocosm and microcosm, meditation, the observance of nature, and the workings of the mind all figured heavily into metaphysical discourses in which William James participated as well as in the general spiritual tenor of late-nineteenth century America into which Stein was born and educated. As Ulla Dydo pointed out, more knowledge of Cambridge in the 1890s would help illuminate the intellectual atmosphere of Stein's formative years and offer new ways of thinking about her work (Dydo 2003).

\section{Meditation and the Late-Nineteenth Century Metaphysical Ferment}

By the nineteenth century's last decade, when the college-age Stein was engaged in her studies, Cambridge, Massachusetts had long been an epicenter of American metaphysical thought. In the decades prior to James's tenure there, Harvard was home to the birth of Transcendentalism, which heralded a new non-doctrinal spirituality. Led, in effect, by Emerson, the Transcendentalists looked for inspiration to German Romanticism; the relatively new field of Biblical criticism, which engendered a newfound religious skepticism; and the theosophy of seventeenth-century Swedish mystic Emmanuel Swedenborg. If the previous generation "beheld God and nature face to face" and "we through their eyes", Emerson wrote, "why should not we also enjoy an original relation to the universe?" (Emerson 2004a, p. 9). True to the democratic spirit of American religion, such individual revelation was available to all, and Emerson, and his friend Henry David Thoreau, sought it through solitary communion with nature.

It was Emerson and the mystical writings of Swedenborg that, in turn, served as foundational ideas in William James's work on religion (E. Taylor 2011) ${ }^{3}$. At Harvard, James's capacious intellect produced an extensive body of work covering psychology, religion, and pragmatism, a school of philosophy he helped found. After initially veering into medicine, James sought his entire life to bring science and spirit into harmony. In the 1880s, inspired by the wellspring of new religious activity flowing around him, James sought scientific evidence for psychic and religious phenomena (ibid, p. 22-23) ${ }^{4}$. His better-known laboratory work on attention, states of consciousness, and the psycho-physical connection — the influence of which on Stein's writing has been explored at length—unfolded alongside his work on witchcraft, trances, mesmerism, mystical encounters, and the newly fashionable practice of meditation ${ }^{5}$.

James's fascination with meditation reflected a wider trend in late-nineteenth century American religious liberalism towards mental healing, mesmerism, and silent, solitary contemplation. As Schmidt describes it: "the burst of interest in meditation involved a peculiarly American conversation among Transcendentalists, liberal Protestants, Reform Jews, Vedantists, Buddhists, and mind-cure

3 Eugene Taylor, a William James scholar and former professor of psychology at Harvard, considered "Swedenborg and Emerson" to be the "primary philosophical frame of reference for understanding James". For his social and political context, Taylor placed James in the "American utopian socialism of the 1840s, to which James was a direct heir through Henry James, Sr. and Emerson" (E. Taylor 2011, pp. 182-83).

4 James, primed for belief by his upbringing, never desired to empirically "explain away" such phenomena but rather to redefine the psychological and religious expanses of human experience. In 1885, James built his own temple for the systematic exploration and documentation of spiritual phenomena in co-founding the American Society of Psychical Research. Overseen by Harvard luminaries, committees including Experimental Psychology, Thought-Transference, Apparitions and Hallucinations, Mediumship, and Hypnotism reveal the late-nineteenth century zeal for empiricism and the desire to scientifically investigate what was happening in metaphysical discourse (E. Taylor 2011, pp. 22-23).

5 His influences from the metaphysical community are too many to name here, but Jamesian scholarship, Eugene Taylor's in particular, show that James readily defended vernacular metaphysics (he testified on behalf of mind-curers to the Massachusetts State House), and was himself well-versed in principles of New Thought and the therapeutic dimensions of positive thinking and meditation. 
metaphysicians" (2005, p. 17) ${ }^{6}$. James, for his part, published his 1899 essay "The Gospel of Relaxation", in which he recommended physical activity and mental repose as antidotes to the stresses produced by the excitable American character.

The eclectic spiritual paths that came together to form this turn of the century fascination with meditation tell us that Stein's use of the word was plucked partially from her time experimenting in the psychology lab and partially from the spiritually-charged zeitgeist in which she spent some of her early years. They also remind us that the religious eclecticism we associate with the 1960s and 1970s counterculture-a religious eclecticism we also find in American avant-garde artists influenced by Stein, such as the Living Theatre and Richard Foreman-stretches further back to the strain of metaphysics that permeated Stein's world, thought, and the theatrical work to which we now turn.

\section{Meditation and Landscape Dramaturgy}

Much has been written about Stein's concept of landscape both as it manifests in her writing and how that has been translated to the stage. In her essay "Plays", Stein described a creeping anxiety that overcame her at the theater as the narrative unfolding before her outpaced her emotional involvement. The story on stage and her inner response were out of step, causing what she termed "syncopation", an uncomfortable feeling she then sought to remedy. She thought if she could remove narrative, remove causality, and therefore remove time from on-stage action, such feelings of syncopation would end. To do this, Stein moved away from a linearly unfolding narrative to juxtaposing images, objects, and words in space, placed as if in a landscape.

Looking at natural landscapes transformed her way of imagining her writing. In an oft-quoted excerpt from Plays, Stein captures the sensation of her eyes gliding across a vista, marking one thing in relation to another: "the trees to the hills the hills to the fields the trees to each other any piece of it to any sky and then any detail to any other detail". "And of that relation", Stein writes, "I wanted to make a play" (Stein 1967, p. 77). Narrative and incident, the time-bound dimensions of more traditional theater, cool into static images or fragment into other "objects" placed in space. "A landscape does not move", Stein wrote, "nothing really moves in a landscape but things are there, and I put into the play the things that were there" (ibid, p. 80).

To observe the "things that were there", Stein engaged in what she called "meditation". Much like the mental concentration or contemplative devotion implicated in the religious sense of the word, Stein used the term meditation to indicate the "process of realizing perception". Ulla Dydo went so far as to call this process of "becoming conscious" a "sacramental act", As Dydo explains: "To meditate, for Stein, meant to concentrate all her attention on what she saw immediately before her" ((Dydo 1988, p. 47). Stein's meditation was inextricably linked to the phenomenology of gazing, often at natural landscapes, and capturing what she saw in language.

6 When Americans began to encounter Asian traditions, meditation and yoga were seen as paths to mental clarity and concentration, tonics against an increasingly anxious and fast-paced culture. Vedantist Swami Vivekenanda and the Sinhalese Buddhist monk Anagarika Dharmapala, in particular, traveled widely on the American lecture circuit, promoting Hindu and Buddhist spiritual techniques for mental focus and well-being. Schmidt also locates a home-grown strand of meditation practice in the "optimistic gospel of mental healing and positive thinking" known as "New Thought" (Schmidt 2005, p. 17). Horatio Dresser, James's friend and colleague at Harvard, and Ralph Waldo Trine, whose best-seller In Tune With the Infinite James read and quoted, were both star players in the New Thought movement, and James observed in the Varieties that the current vogue for contemplative practice stemmed not from evangelical Protestant devotional prayer but from "our mind-curers," who had "reintroduce[d] methodical meditation into our religious life" (p. 147). Trine and another fellow New Thought devotee, Henry Wood, both recommended "a daily practice of meditation and concentration, performed in solitude and silence in a seated restful posture" to quiet a wandering mind, sharpen concentration, and draw into life the abundant "divine inflow" (p. 147). Annie Besant, a second-generation leader of the Theosophical Society, wrote extensively on meditation's role in the quest for divine knowledge. Heavily influenced by some Buddhist and Hindu devotional practices, Besant championed mental "one-pointedness" or samadhi, a state of intense meditative focus that lead to transcendent consciousness. The difficulties of this practice are made clear in Besant's counsel: "When the mind loses hold of its object, whether devotional or intellectual—as it will do, time after time—it must be brought back, and again directed to the object" (pp. 108-9). 
But as Elinor Fuchs observed, it is ultimately unclear when Stein talked about plays as landscapes whether she meant a way of seeing or thing to be seen-the inner world of perception or the outer one of material reality. Fuchs wrote that Stein uses the term landscape to describe "a phenomenological spectatorship of theater, a settled-back scanning or noting" of textual or spatial patterning, "as if it were a natural scene" (Fuchs 1995, p. 94). But for Stein, this way of seeing seems to go hand in hand with actual nature imagery. In her first sense of the term landscape, Fuchs interprets Stein's notion of landscape in two ways: it is "spatial and static instead of temporal and progressive", i.e., a way of seeing (95). And second, it also refers to a self-contained theatrical world in which images of nature appear. Fuchs stresses the spectator's shift towards surveying the visual field in its entirety, her attention held not by "structures arranged ... on lines of conflict and resolution" between characters "but on multivalent spatial relationships" (107). Through this kind of attention, we find ourselves neither "transported to another world" nor do we "banish all other worlds", but rest firmly in a timeless now akin to a shift in consciousness produced during meditation (107). Stein's writing-as-meditation is designed to produce a meditative effect on the spectator-what Stein called the "continuous present".

Metaphysical religion on stage has always been considered the special province of the Symbolists, with Maurice Maeterlinck as the leading light. Fuchs asked if we might consider Maeterlinck's eloquent Symbolist stage and Stein's landscape dramaturgy as "variants of a similar modern tradition, these two static, spatial theaters with their concomitant resort to landscape" (ibid, p. 70) ${ }^{7}$. As variants of a modern tradition, Fuchs saw the immanent, static eternal of Maeterlinck and the repeated beginnings of Stein's continual present as two time signatures "embedded" in each other. Unlike Maeterlinck, Stein never sought to stage the intersection of visible reality and the invisible spiritual world through mystical correspondences, but we might think of Stein's continuous present as a secularized version of the immanent eternal.

Stein's method of writing-as-meditation translated to the stage the constant process of beginning again and again, which mirrors a kind of meditative practice requiring the meditator to continually bring the mind back to its object of concentration when it began to wander. For many of the nineteenth-century mystics advocating for meditation, its ultimate goal was the same as Emerson's—uniting the human mind with the divine mind, accessing divine knowledge, and healing the human being. For Stein, as we shall see, meditation's highest end was to settle into the continuous present of the human mind in order to produce masterpieces.

Stein's revision of Emerson and James brought together metaphysical correspondences, linguistic skepticism, meditation, movements of the mind, and contemplation of nature. In linking the religious content of Stein's landscape plays to William James's concept of "knowledge of acquaintance", Rebecca Kastleman argues that the primary form of knowing presented in landscape dramaturgy "is epitomized by religion, which represents a form of knowledge that is experienced and felt but not fully available to thought" (Kastleman 2019, p. 345). She effectively shows how Stein, like many other Modernist writers, "rehabilitated religious experience as an aspect of the aesthetic" (354). Re-reading Stein through the wider context of late-nineteenth century American religious liberalism, and through Albanese's definition of metaphysical religion in particular, Stein's own preoccupations with the mind and mental phenomena reveal new associations. Stein's explorations of attention, consciousness, self-consciousness, and awareness stem not just from the advent of modern psychology but also from what Eugene Taylor calls psychology's "shadow culture" of folk healing and vernacular magical practices in the lineage that both he and Albanese trace. Stein's most significant theoretical contributions to the theatre-her

7 Is it any wonder that Maeterlinck considered Emerson his "avowed master and greatest influence", publishing an essay on his mysticism and writing the introduction to a French translation of his essays (Moses 1920, p. 11)? When The Treasure of the Humble, which contained Maeterlinck's influential essay on static drama, "The Tragical in Daily Life", was published in 1896, he was summarily hailed as the "Belgian Shakespeare" and the "European Emerson" (Frothingham 1912, p. 251). Perhaps Symbolism's mystical language of correspondences and symbolic landscapes is as much Emersonian as Baudelairean, and American religion had a significant influence on the early European avant-garde as well as its native one. 
notion of landscape dramaturgy and the continuous present-all reflect her preoccupation with mind and an idiosyncratic interest in nature that has roots in the metaphysical language she inherited.

\section{Stein's Revised Correspondences: Human Nature and Human Mind}

Gazing out at the French countryside of Bilignin, Stein's visual field inspired in her a new way of making plays: "I found that since the landscape was the thing, a play was a thing and I went on writing plays a great many plays. The landscape at Bilignin so completely made a play that I wrote quantities of plays" (Stein 1967, p. 75). Stein's transformation of nature into art provides another example of how Stein revised metaphysical concepts explored by Emerson.

For Emerson, meditative engagement with the natural world could vault the individual into an experience of his or her own divinity. In Nature, he wrote: "Man is a god in ruins", but "the problem of restoring to the world original and eternal beauty is solved by the redemption of the soul". Once indivisible, man and nature now live estranged, but to awaken to this "kindred impression" between humanity and the natural world, to feel the "perpetual presence of the sublime", one need only "go into solitude", "look at the stars", and partake in the "wild delight" that "every season and hour yields" (Emerson 2004a, p. 11). In a famous sequence, Emerson related his own ecstatic encounter in nature: "Standing on bare ground-my head bathed by the blithe air, and uplifted into infinite space-all mean egotism vanishes. I become a transparent eye-ball; I am nothing; I see all; the currents of Universal Being circulate through me; I am part or particle of God" (12). Emerson elsewhere described this kind of revelation through the ancient system of metaphysical correspondences linking the world and the individual human spirit as "an influx of the Divine mind into our mind", a "shudder of awe and delight with which the individual soul always mingles with the universal soul" (Emerson 2004b, p. 193).

But beyond kinship and sublime wonder, Emerson described how nature might be used to restore to man a kind of divine power through beauty and language. Beauty is generative: "The beauty of nature reforms itself in the mind", he wrote, "and not for barren contemplation but for new creation". Gazing at nature's beauty inspires in the artist a desire to create beauty herself: "Thus is Art, a nature passed through the alembic of man" (Emerson 2004a, p. 20).

In placing "the things that were there", as Stein states in Plays, into theatrical space, objects in nature similarly passed through her unique consciousness and transmuted into art. In Stein's re-formulation of Emerson, however, the purpose of transforming nature into art is not to connect the universal to individual souls through new creation, as Emerson says. What we shall see is that Stein, like many other Modernists—as Kastleman observed—secularized religious ideas, in this case replacing divinity with art as humankind's source of transcendence.

Stein further fleshed out the relationship between the mind and natural landscapes in her book The Geographical History of America. To understand her ideas, we first have to define some of her idiosyncratic terms. In Geographical History she describes her own version of correspondences between the macro and microcosmic spheres: rather than an Emersonian "influx of the Divine mind into our mind", Stein creates a unique but analogous set of categories and details the "relation" between what she terms "Human Nature" and "Human Mind". Human Nature, for Stein, translates to individual identity-the vicissitudes of individual existence. It is subject to time's flow, and acts as its own audience, self-consciously observing itself. As Thornton Wilder summarized about Stein's book: "Human Nature, in order to be sure that it exists, must employ audience and memory. Memory informs it that it was itself in the past, and audience reassures it that it is itself in the present". Human Mind exists outside of time. Not bound by continual shifting awareness from past memory to future projections, the Human Mind, in "every moment knows what it knows when it knows it". It rests in the present moment, and does not require an outside source of input to know itself (Burns et al. 1996, pp. 362-63). Kate Davy describes Geographical History as Stein's philosophical system and includes with her article a chart of correspondences drawn from Stein's text. Human Nature and Human Mind 
are Stein's personal version of metaphysical, cosmological correspondences, and Davy's chart only furthers this point.

Rather than positing a smaller, more limited human consciousness in relation to a divine one, Stein offered two aspects of the human, which never need open to "higher" realms. The human being herself contains both entity and identity, both a timeless mind and a time-bound nature, and Stein repeatedly asserted that "there is no relation" between human nature and the human mind. Individual human nature does not evolve towards divinity as her metaphysical counterparts suggest. Instead, Stein secularizes these metaphysical models, closing what Charles Taylor calls the immanent frame, and eliminating the conduit to other realms entirely. We might understand Stein's vision of the mind moving entirely in a horizontal plane of existence, an endless sweep without vertical reach: "yes the flatter the land the more yes the more it has may have to do with the human mind" (Stein 1936, p. 113). And this horizontality manifests spatially in the span of the landscape stage.

Geographical History also further developed Stein's thoughts on the relationship between landscapes and national character. Her preference was for American geography because of its "flatness". She wrote: "That is what makes land connected with the human mind only flat land a great deal of flat land is connected with the human mind and so America is connected with the human mind. I can say I say so but what I do is to write it so. Think not the way the land looks but the way it lies that is now connected with the human mind" (ibid, p. 51). America's flatness had less to do with geography than cartography: she connected physical wandering to mental wandering, both provoked by "the straight lines on the map of the United States of America", which "make wandering a mission" (ibid, p. 57). Whatever America's actual geographic features, those peaks and ponds praised by Transcendentalists, Stein's America is "a country so big that it is divided one part from the other by ruled lines and it has to be flat" (ibid, p. 59). The American landscape's continuous horizontality, as viewed from a great distance or abstracted into the lines on a map, means that "the land has something to do with the human mind but nothing to do with human nature" (ibid, p. 81). And Stein's aim was not just to "say so" but "to write it so", to capture on the page this illimitable expanse, natural and mental, unbound by time and space.

Stein's true object of meditation in Geographical History revealed itself to be the nature and purpose of literary masterpieces. Why had The Illiad survived the centuries? Why do we still read Shakespeare or Jane Austen or the Bible? And moreover, what exactly makes them the enduring works that they are? She surmised, as Thornton Wilder wrote, that though such masterpieces may traffic in the sort of local details that comprise human nature, they are ultimately products of the human mind, the "principal expression" of which "is in writing and its highest achievement has been in literary masterpieces". In his introduction to Geographical History, Wilder tells us that encountering these masterpieces, the "vast multitudes of the world who [strive] to escape from the identity-bound and the time-immersed state, recognize that such a liberation has been achieved in these works" (ibid, p. 8). Wilder's language here evokes a particularly metaphysical soteriology with clear hints of Buddhist and Hindu influence. In general, the purpose of meditation, according to some Buddhist and Hindu doctrines, is to release the individual from samsara, a term shared by the two religions which denotes the endless cycle of suffering and rebirth to which all embodied (read: identity-bound and time-immersed) beings are subjected. Buddhists speak of nirvana and Hindus speak of moksa, both of which are often translated as "liberation" from samsara (Keown 2004; Johnson 2009). Here Wilder invoked the thread of Asian traditions that runs through metaphysical religion, without connecting it to any specific doctrine or lineage.

In Geographical History, Stein playfully revised the entire metaphysical project for a modern culture of doubt. "Human Mind" replaced "Divine Mind" as the timeless, boundless entity towards which the writer/devotee aspires. And while this is no devotional handbook, Geographical History suggests that the ultimate goal of "liberation", of escape from the limitations of human nature, could be attained through encounters with masterpieces of literature. Through her Modernist aesthetics, Stein articulated a deeply Romantic notion of the salvific nature of art. A masterpiece is a material manifestation of the 
human mind. Both are timeless—-they "have no finishing in them" - and may on the surface engage with human nature but are ultimately removed from it (Stein 1936, p. 194).

Stein borrowed these relationships from the world of metaphysical religion around her, but she changed them in fundamental ways. And she changed the form of writing to reflect its content. The emotional peaks and rhetorical valleys of Romantic writing in general could never capture Stein's notion of American geography and its flat landscape or the horizontality of the modern social imaginary. For Stein, there is no Thoreauvean epiphany on Mount Ktaadn or a Jamesian "Walpurgisnacht experience" on Mount Marcy. There was no god of interest to Stein in heights or abysses. Stein's perception of the American landscape's perpetual flatness became a governing image for the timelessness and eternity of art rather than God. She recapitulates a Romantic religious upheaval in a modern register substituting the Human Mind for Emerson's Divine Mind and the "Master-piece" as the Human Mind's omega point. Her idiosyncratic prose style extends the experience of her Human Mind to her reader's Human Mind, forcing, through word-by-word attention, a simple resting in the timeless flow of writing. For all its difficulty, it is a generous style that allows the reader to share Stein's thought process through its perfect blend of form and content.

When Stein turned to the theater, she sought to create in her spectators a sensation similar to reading and writing. Her dramatic landscapes aim for the same by hovering always in the continuous present, a result of her distaste for syncopation. The sensation of reading Stein's writing and of viewing landscape dramaturgy in action both capture a kind of attention similar to the practice of meditation. In reading, the magnetic pull of her style continuously returns the eye to each word after individual word. In viewing, the eye similarly drifts from thing to thing to thing across the stage. And Stein's work consciously places the spectator in her subject position-that is, in the subject position of the meditator. It is this desire for an individual encounter with the work of art, with the masterpiece, that places Stein the continuum of American religion, which James called a fundamentally individual encounter with the divine. The mental magic of turning the vastness of nature into art is Stein's metaphysical operation leading to human "liberation" through literature: behold natural landscapes, transmute natural landscapes to an aestheticized vision, cultivate inner landscapes, place these inner landscapes on stage in the form of a masterpiece, and use them as vehicles for connection with the infinite (though not divine) source that is the Human Mind. The object of Stein's reformation of Emerson is salvation by masterpiece ${ }^{8}$.

In Wilder's introduction to Geographical History, he asks: "If then Miss Stein is writing metaphysics, why does she not state her ideas in the manner that metaphysicians generally employ?" He answers his own question, saying that in order to decouple previously used terminology from prior systems, metaphysicians must invent their own "private language". Second, Stein is an artist, a being far more engaged with poetry than theory, and she writes in a series of "metaphysical metaphors". Wilder's answers situate Stein in a continuum of thinking about metaphysics, modernity, art, and God that coalesce at the end of the nineteenth and turn of the twentieth centuries. As Charles Taylor observed, the advent of modernity brought about "new conditions in which belief and unbelief uneasily coexist" (C. Taylor 2007, p. 295). Stein invented her own terminology to describe the workings of her consciousness, but her terms borrow from several centuries of American metaphysical discourse. Stein removes the metaphysician's vertical axis connecting self and divinity (Emerson's "Divine mind into our mind") and turns it into an ever-expanding horizontality. She creates terms that share resonances with a belief system but strips them of belief, or at least casts a skeptical eye towards it, and renders the relationship between Human Nature and Human Mind a thoroughly humanistic one. Though Human Mind is timeless, without memory, without individual identity and appears to encompass Human Nature, it is also never associated, like its metaphysical analogues, with

8 As Albanese wrote: "Emerson was connecting human will to a higher source of will and desire, and he was arguing for the release of the self into that vastness - a thoroughly metaphysical logic that would come to characterize some late-nineteenth-century American spirituality" (Albanese 2007, p. 167). 
transcendence. Art enters the picture as a possible recourse to divinity, or if not divinity, something deeper in the world.

On the salvific nature of art, Charles Taylor shows how art, as a category, emerged in the Romantic era and served as a possible sphere for exploring and disclosing "very deep truths which in the nature of things can never be obvious, nor available to everyone, regardless of spiritual condition" (ibid, p. 356). Art was elevated to a space in which religious feeling was formerly the only occupant, and to art was bestowed the power to articulate a sense of mystery that may or may not stem from divinity. Unbelief need not lead to materialism, nor belief necessarily lead to religion. Rather, a spectrum of belief opened up-from an atheistic "mystery of anthropological depth" to religious orthodoxy, with nature, art, and the "spiritual" all offering various shades in between. Taylor credits art with filling the void left by the breakdown of received public doctrine. "Where formerly poetic language could rely on certain publicly available orders of meaning"-the Renaissance doctrine of correspondences or the Great Chain of Being, for example- "it now has to consist in a language of articulated sensibility" - that is, an idiosyncratic language issuing from the individual artist (ibid, p. 253). The Romantic period, Taylor argued, required "subtler language" to describe that which exists outside of the "pre-existing lexicon of references", and the artist provided that new language (ibid, p. 354). By way of example, Taylor offers Rilke's angels in the Duino Elegies: "We cannot get at them through a medieval treatise on the ranks of cherubim and seraphim, but we have to pass through this articulation of Rilke's sensibility" (ibid, p. 353). Stein similarly creates her own quasi-metaphysical terms, as Wilder states, her own subtler language, to nod to the metaphysical tradition she inherited, and she revised it to encompass a sense of skepticism.

\section{Four Saints in Three Acts}

Metaphysical religion, landscape, and the elevation of art all coalesce in Stein's 1927 libretto for Four Saints in Three Acts, an opera she co-wrote with American composer Virgil Thompson. The prologue of the play, subtitled "A narrative of prepare for saints", tracks the mind of a writer engaged in the act of writing the very opera libretto we read on the page or view in performance (Stein 2016, p. 15). Stein stages the mind in action by assigning to a chorus of saints the various subjects that cross her mind as she prepares to write. Her wandering language skips from one thought to the next until she dutifully returns to the object of her meditation: the play she is writing. From the task of preparing for saints, she moves without transition into a short digression about "what happened today, a narrative", until she suddenly returns again to setting the scene of her opera: "Imagine four benches separately" (ibid, p. 15). Four Saints captures this continual process of thinking, disruption, and return. As Marc Robinson states, "In Four Saints, the work of prayer", its rigorous turning and returning to God, "stands in for the work of writing, and both are distinguished for their arduousness as much as their ardor" (Robinson 2009, p. 196).

In addition to saints and other images of religious piety, the play teems with nature imagery. The time that elapses across its many scenes and tableaux trace both a seasonal and mental thaw, moving from "April fools' day" to "June and June" (Stein 2016, pp. 19, 35). As early spring melts into summer in Avila, Stein slowly discovers how "Saint Teresa half in doors and half out of doors" will have finally, halfway through the play, "begun to be in act one" (ibid, pp. 19, 24). She seems to worry how exactly to get all of the saints on stage and how to rather unsymmetrically fit four of them into only three acts: "Four saints two at a time have to have to have to have to" (ibid, p. 16). But as the world begins to burst into bloom, suddenly there is "Saint Teresa advancing" along with Stein's own ideas (ibid, p. 21). In and amongst images of a cloistered garden, a tree, eggs, "pear trees cherry blossoms pink blossoms and late apples", magpies and pigeons in the grass, we find "St. Teresa II in ecstasy" and a "Vision of a Heavenly Mansion", two images associated with the real life Teresa's euphoric devotion (ibid, pp. 23, 29). But the play does not end with Teresa's religious apotheosis; it ends with Stein's secularized metaphysical one. 
Robinson's gorgeous reading of Four Saints alongside St. Teresa of Avila's The Interior Castle compares the authors' individual journeys towards deep interiority: Teresa's goal is to unite with God in that innermost secret space of the self, but Stein desires to fully unite with her own process of thought, to make her way to the Human Mind, and capture the monumental work of writing a masterpiece. To describe the religious work the piece performs, I would suggest that perhaps Stein's saints have more in common with the sanctified loafing of Walt Whitman than with anything particularly Catholic about the rigors of Catholic mysticism. Though she writes that "saints are never idle", their placement in the landscape of the play invite audiences, too, to loaf, to behold. If for Whitman the ecstatic gazing at American panoramas engendered mystical union with spirit, for Stein, witnessing the moment-by-moment flow of thought, the image-by-image task of writing, engendered the liberating force of art.

In the "Prologue to Act IV", Stein returns to the question that she has turned over and over earlier in the play: "How many saints are there in it" (ibid, p. 27). But now she rephrases the question: "How many acts are there in it" (ibid, p. 34). She asks both, repeatedly until the answer arises, and she announces triumphantly: "Four acts. Act Four." And here Stein thrusts the saints into the celestial realm as she finds her way towards the play's completion. There is "no scenery but the sky, with tumultuous clouds and a sunburst. Saints in Heaven". This is not Bernini's Teresa in ecstasy with the looming angel ready to pierce her breast from above, nor is it the vertical expanse conjured by the image of the heavenly mansions. Stein's heaven here is the infinite horizontality of sky, of the Human Mind, and of the artistic masterpiece. She emphasizes this horizontality in the language as well as the mise-en-scène: "They have to be to see. To see to say. Laterally they may". And later, in a kind of blessing: "Saint Ignatius and left and right laterally be lined". Finally satisfied with what she has wrought, Stein declared the fourth to be the "Last act. Which is a fact" (ibid, p. 35).

Here Stein created a theater of ever-unfolding expansion, vast horizontal reaches without end, plotless and therefore timeless, as the spectator watches, with total absorption, her thoughts arising onstage. Stein's image of the celestial realm offers not a vision of an eternity to come but a taste of how transcendent realms may be accessible within the here and now - the continuous present-through gazing at worldly landscapes. Dydo writes that Stein rejected structures that were "vertical, hierarchical, and fixed. The landscape of Stein's world is horizontal, democratic, and fluid. In it all things and all words are of equal value; nothing is more important than anything else nor are words permanently attached to things. To call hers a comic world means that nothing is sacred but that everything is sacred, from small to large, from near to far, from word to word" (Dydo 2003, p. 57). This is not just true of Stein's world but of the larger shift away from the "vertical" and "transcendent" into the "closed" and "horizontal" "modern cosmic imaginary" Taylor described (C. Taylor 2007, p. 556).

So we have seen a way of thinking about Stein's most significant dramatic ideas that takes into account the particularly American religious background that surely helped form them. She adopted metaphysical language, but in the spirit of Emerson and James-as Richard Poirier suggested-makes that language less precise, more vague, at once permeable but more capacious, reflecting modernity's turn towards secularism. Stein opened metaphysical systems to doubt, leaving room for postsecular choice. Though a Modernist, Stein, like her Romantic antecedents, elevated artistic masterpieces to a third space, one that was no longer religious but not entirely secular. Her work and ideas carry the deep imprint of this particular metaphysical language, and though we may not call her work overtly religious, some trace of transcendence remains. Perhaps this is what Robinson meant when he described a searching quality in Stein's plays, a "mysticism aris[ing] from their placid surface", a "longing for more certainty" that "gives Stein's theater a strangely spiritual aspect" (Robinson 1994, p. 19). The progenitrix of the other American drama was formed in the same crucible as the other American religion. 


\section{Coda}

Stein's work sits at a thorny, postsecular nexus between a disenchanted, bounded, modern universe and an enchanted, porous, mystical world. Her theatrical inheritors and interpreters have likewise inherited both of these sets of meanings, and when they channel Stein, they channel both the metaphysical mists and the skepticism from which her work sprung. This tension is often visible in their works. Postmodern theater-makers took up Stein's project, further fleshing out her theories about writing in the dimensional space of the stage. The influence of Stein on the works of the Living Theatre, Richard Foreman, the Wooster Group, and others has been traced more fully elsewhere, but here I will mention a few. To return to the web of associations that tie Stein to American metaphysical religion and its roots in liberal Protestantism, it seems more than coincidental that many of these later artists who have been deeply in dialogue with Stein's formal dimensions have also found themselves engaged with the combinative nature of American metaphysical spirituality.

Alisa Solomon observed that from its midcentury emergence, experimental performance in America engaged in dialogue with religion, both within the institutions that supported it and in the content of the work itself. Institutions such as "Theater Genesis in St. Mark's Church under rector Michael Allen; Judson Poets' Theatre under minister Al Carmines at the Judson Memorial Church; and the Theater at St. Clements under its vicar Sidney Lanier"-key figures in the Off-Off-Broadway movement-grew out of artistic and social programming produced though liberal Protestant congregations (Solomon 2011, p. 13). Bread and Puppet, the Living Theatre, and the Performance Group were among the most visible companies that staged their call for political and spiritual transformation through experimental dramaturgies.

Starting with the Beat generation of the mid-1950s, a mistrust of scientific rationality and institutional religion sparked spiritual revivals, an interest in Eastern traditions, and a fascination with eclectic forms of metaphysical religion. To engage with the religious concerns of the 1960s and 1970s counterculture, theater artists looked to prophets of their own like Antonin Artaud, whose The Theatre and Its Double was translated into English in 1958, and the experimental laboratory of Jerzy Grotowski. For other alternative dramaturgies, they also looked to Stein. Though her engagement with the sacred was far less overt than in the work of Artaud and Grotowski, Stein's secularization of metaphysical concepts paradoxically paved the way for both sincere ritualized theatrical events that aimed to incite spiritual and political revolution (as in The Living Theatre and the Performance Group) as well as far more skeptical works that resist spiritual communion (as in the Wooster Group or Richard Foreman).

The Living Theatre, like many American experimental artists, cut their teeth on Gertrude Stein. In 1951, five years after their founding, they staged Stein's opera libretto Doctor Faustus Lights the Lights (1938) in a program of poetic dramas rarely produced in America at the time. Their most famous work, Paradise Now (1968), though not particularly Steinian, was structured according to a host of metaphysical references, including the ten sephirot, or emanations, of Kabbalah as well as the I-Ching and the chakra system. Part happening, part rite, the company lead the audience through a series of "rituals, visions, and actions" to usher in a new world through non-violent revolution (Walker 2019). As Christopher Innes wrote of the Living Theatre: "They repeatedly termed their political aim "prophesying", described their theatre as "performing a ceremony" and its intended effect as "absolute communion", referred to the actor as "a priest" or "shaman", and pointed out their "concern with primitive and mystic rituals"" (Innes 1981, p. 187). This combinative spirituality, bringing together medieval Jewish mysticism, a Chinese divinatory system, and the Hindu-Buddhist centers of spiritual energy in the body directly reflects the language of American metaphysical religion.

Elinor Fuchs argues for a connection between Stein's landscape dramaturgy and the works of various postmodern theater-makers whose pieces feature "non-linear spatial structures, and are concerned not with individual character or a temporal progression but with a total state or condition" and "also draw important moments of imagery from natural landscape" (Fuchs 1995). Fuchs pivots away from connections to natural landscapes when discussing the works of Richard Foreman and Liz LeCompte, arguing instead for a concept of "mindscapes", particularly in the case of Foreman.. 
Richard Foreman has long decked his hermetic mindscapes with occult symbols, Hebrew letters he does not read, and Jewish prayer paraphernalia. If, as Albanese suggests, American metaphysical religion has served to democratize the occult, Foreman's project may be said to re-consign such secrets to the shadows. Foreman presents occult signs that point back to nothing, divulging secrets in languages we no longer speak, offering esoteric mysteries into which no one can be initiated. Foreman, who directly acknowledges his debt to Stein, also described himself as a "closet religious writer" (Foreman 1992, p. 5).

The Wooster Group's engagement with American metaphysical religion is subtler, but many of their productions use technology to channel the voices of the dead. In Rumstick Road (1977), one of their earliest works, audio recordings of Spalding Gray's deceased family members featured prominently in the technological warp and weft of this experimental memory play, which also borrowed text from Mary Baker Eddy's writings on Christian Science. Ron Vawter's now-famous rendering of Vershinin's final speech in Fish Story (1994), recorded and glowing through screens present on stage, allowed the dying Vawter to remain in this world as he stepped one foot into the next. In 2007's Hamlet, Richard Burton's staging of Shakespeare's play came alive in the theater again, embodied and voiced by company members performing in front of a recording of Burton's 1965 production. Theater itself, usually consigned to that undiscovered country from whose bourn no traveller returns, was here released from its videotaped purgatory to speak again through a willing company of mediums. In Early Shaker Spirituals (2014), a "record album interpretation", the Group channeled Shaker women who were believed to have received messages from the spirit world and captured them in song. It also bears noting, particularly with regard to Early Shaker Spirituals, that in a rediscovered chapter of Thomas Edison's diary-recovered in 2015-Edison discussed his desire to create a phone to the afterlife. In the post-WWI Spiritualist revival, Edison sought to capture the voices of the departed through technology and detailed his scientific theory explaining how these voices might be recorded. While the Wooster Group's technological obsessions may spring more recently from experiments with postmodern intermediality, the roots of these obsessions stretch far further back into the shadowy spaces of American religious longing.

While this article has primarily focused on the religious reverberations in Stein's work, a fuller picture of the metaphysical avant-garde would bring the spiritual resonances in Stein together with a greater exploration of the ritual performances of midcentury. It might ask why the skepticism in Stein gives way to the sincerity of communal ritual in groups like the Living Theatre and the Performance Group only to be replaced by skepticism again in Foreman and the Wooster Group. It might ask how Stein's dramaturgy and the current occult revival come together onstage today. It might ask why Reverend Al Carmines, Off-Off-Broadway pioneer, the liberal Protestant minister at Judson Memorial Church, founder of Judson Poets' Theater, and composer of five musicals about Gertrude Stein, articulated his own conflation of God and art this way: "If you want to know how to live, go to church. If you want to know how your life is in its deepest roots, go to the theater" (Martin 2005).

Funding: This research received no external funding.

Conflicts of Interest: The author declares no conflict of interest.

\section{References}

Albanese, Catherine L. 2007. A Republic of Mind and Spirit: A Cultural History of American Metaphysical Religion. New Haven: Yale University Press, pp. 1-21.

Bay-Cheng, Sarah. 2004. Mama Dada: Gertrude Stein's Avant-Garde Theater. New York: Routledge, p. 119.

Burns, Edward M., Ulla Dydo, and William Rice, eds. 1996. The Letters of Gertrude Stein and Thornton Wilder. New Haven: Yale University Press, pp. 362-63.

Davy, Kate. 1978. Richard Foreman's Ontological-Hysteric Theatre: The Influence of Gertrude Stein. Twentieth Century Literature 24: 108-26. [CrossRef] 
Dydo, Ulla E. 1988. Gertrude Stein: Composition as Meditation. In Gertrude Stein and the Making of Literature. Edited by Shirley Neuman and Ira B. Nadel. Boston: Northeastern University Press, p. 47.

Dydo, Ulla E. 2003. Gertrude Stein: The Language That Rises, 1923-1934. Evanston: Northwestern University Press, pp. 265-66.

Emerson, Ralph Waldo. 2004a. Nature. In Essays and Poems of Ralph Waldo Emerson. New York: Barnes and Noble Classics, pp. 7-49.

Emerson, Ralph Waldo. 2004b. The Over-Soul. In Essays and Poems of Ralph Waldo Emerson. New York: Barnes and Noble Classics, pp. 186-201.

Foreman, Richard. 1992. Unbalancing Acts: Foundations for a Theater. New York: Pantheon Books, p. 5.

Frothingham, Paul Revere. 1912. The Mysticism of Maeterlinck. Harvard Theological Review 5: 251-68. [CrossRef]

Fuchs, Elinor. 1995. The Death of Character: Reflections on Theater after Modernism. Bloomington: Indiana University Press, pp. 92-107.

Innes, Christopher. 1981. Holy Theatre: Ritual and the Avant Garde. Cambridge: Cambridge University Press, p. 187. James, William. 1895. Is Life Worth Living? International Journal of Ethics 6: 1-24.

Johnson, W. J., ed. 2009. Moksa. In A Dictionary of Hinduism. Oxford: Oxford University Press, Available online: http://www.oxfordreference.com/view/10.1093/acref/9780198610250.001.0001/acref-9780198610250e-1629?rskey=Rxb5om\&result=1 (accessed on 8 April 2019).

Kastleman, Rebecca. 2019. An Acquaintance with Religion: Pluralizing Knowledge in Gertrude Stein's Doctor Faustus Lights the Lights. Modern Drama 62: 338-60. [CrossRef]

Keown, Damien, ed. 2004. Nirvana. In A Dictionary of Buddhism. Oxford: Oxford University Press, Available online: http://www.oxfordreference.com/view/10.1093/acref/9780198605607.001.0001/acref-9780198605607e-1267?rskey=SLN7mT\&result=1 (accessed on 8 April 2019).

Martin, Douglas. 2005. Al Carmines, Experimental Theater Force, Is Dead at 69. New York Times. August 13. Available online: https:/www.nytimes.com/2005/08/13/arts/al-carmines-experimental-theater-force-is-deadat-69.html (accessed on 8 April 2019).

Moses, Montrose J. 1920. Forward to Emerson and Other Essays by Maurice Maeterlinck. Translated by Montrose J. Moses. New York: Dodd, Mead and Company, pp. 9-29.

Poirier, Richard. 1992. Poetry and Pragmatism. Cambridge: Harvard University Press, p. 153.

Robinson, Marc. 2009. The American Play. New Haven: Yale Univeristy Press, pp. 186-99.

Robinson, Marc. 1994. The Other American Drama. Cambridge: Cambridge University Press, p. 197.

Ruddick, Lisa Cole. 1990. Reading Gertrude Stein: Body, Text, Gnosis. Ithaca: Cornell University Press, p. 40.

Schmidt, Leigh Eric. 2005. Restless Souls: The Making of American Spirituality. New York: HarperCollins, pp. 1-23.

Solomon, Alisa. 2011. Introduction to The Reverend Billy Project: From Rehearsal Hall to Super Mall with the Church of Life After Shopping by Savitri D and Bill Talen. Edited by Alisa Solomon. Ann Arbor: University of Michigan Press, pp. 3-16.

Stein, Gertrude. 1936. The Geographical History of America or the Relation of Human Nature to the Human Mind. New York: Random Hous.

Stein, Gertrude. 1967. Plays. In Look at Me Now and Here I Am: Writings and Lectures, 1911-1945. Edited by Patricia Meyerowitz. London: Peter Owen, pp. 58-81.

Stein, Gertrude. 2016. Four Saints in Three Acts. Composed by Virgil Thompson. Perf. Boston Modern Orchestra Project. Cond. Gil Rose. Malden: BMOP Sound, CD.

Taylor, Charles. 2007. A Secular Age. Cambridge: Belknap Press of Harvard University Press, pp. 253-556.

Taylor, Eugene. 2011. William James on Consciousness Beyond the Margin. Princeton: Princeton University Press, pp. 182-83.

Walker, Thomas S. 2019. History: The Living Theatre. Available online: http://www.livingtheatre.org/detailedhistory (accessed on 8 April 2019).

(C) 2020 by the author. Licensee MDPI, Basel, Switzerland. This article is an open access article distributed under the terms and conditions of the Creative Commons Attribution (CC BY) license (http://creativecommons.org/licenses/by/4.0/). 
Article

\title{
Toward Witnessing the Other: Syria, Islam and Frans van der Lugt
}

\author{
Michael VanZandt Collins \\ Theology Department, Boston College, Boston, MA 02467, USA; vanzandt@bc.edu
}

Received: 16 December 2019; Accepted: 3 April 2020; Published: 8 April 2020

\begin{abstract}
This article addresses issues and questions at the intersection of religion and theatrical drama from the perspective of Muslim-Christian comparative theology. A case study approaching an actual performance of Shakespeare's Romeo and Juliet from this disciplinary point of view also takes into account the Syrian context, develops a framework for "mutual witnessing", and the practice of drama therapy. Accordingly, the case-method proceeds to address two interrelated challenges. The first is how to relate to the adaptive praxis and theological sensibilities of performers who inhabit a political and religious situation that is radically different from one's own. The second regards in a more specific way of reframing a case of Christian martyrdom in terms of witnessing that remains open and hospitable to religious others, and particularly in this case to Syrian Muslims. As an exercise of comparative theology, this case-method approach focuses on notions of "witnessing truth" that appear and are cultivated in the work of liberation theologian Jon Sobrino and in Ibn 'Arabī's Fus $\bar{u} s$ al-Hikam, specifically the chapter on Shuayb. In conclusion, this exercise turns to the performance itself as a potential foundation for shared theological reflection between Muslims and Christians. As such, this article attempts to render how theatrical action creates a "religious" experience according to the structure and threefold sense that Peter Brook observes.
\end{abstract}

Keywords: Syria; witness; martyrdom; theatrical drama; Romeo and Juliet; Frans van der Lugt; comparative theology; William Shakespeare

\section{A Case Introduced}

On 14 April 2015, the organization Souriyat Across Borders (SAB) hosted a performance of Romeo and Juliet in the attic of its Amman-based hospice ${ }^{1}$. As the primary base of operation for the organization, which was established by Syrian women in the Za'atari Refugee Camp, the rehabilitation center has become a refugee space and a place of recovery for those wounded (in the broadest sense) as a result of the war. While typically focused on physical therapy, issues of mental health increasingly have become a concern due to trauma as a result of the war and difficulties of life in exile and in refugee camps. For the past three months, the production's director Nawār Bulbul has rehearsed with his actors. Bulbul, once an established television-actor in Syria, became a public critic of the regime of Bashar al-Assad in 2012 and subsequently was forced to leave his hometown of Homs for asylum in Jordan. This production is neither his debut nor his first adaptation of Shakespeare's tragedies. In 2014, Nawār Bulbul used Shakespeare's King Lear as the basis of a sprawling epic, commingled with select scenes from Hamlet. ${ }^{2}$ Whereas in that previous performance one hundred children were

1 For more information, see Souriyat Across Borders, http://souriyat.org/. As the name states, the nonprofit organization is founded and operated by Syrian women (sūriyāt is feminine-plural form of Syrians).

2 See (Hubbard 2014). Vimeo broadcasts a 2018 video documentary called "Shakespeare in Zaatari", directed by Maan Moussli, of Nawār Bulbul's production and the 2014 performance in Amman's Roman amphitheater. 
assigned and cast into the roles of that sprawling production, in this case, Bulbul only worked with four war-affected children as actors. Meanwhile, in Homs, four other children as actors have rehearsed and practiced for their roles in this production. With respect to children wounded as a result of the Syrian war, his theatrical experiments are particular instances of "drama therapy", which is premised on the notion that theater can become a medium oriented to and capable of addressing problems that arise due to violence and trauma. To this end, as a primary focus of SAB, the production serves as a collaboration between an artistic endeavor and a health-care facility that specializes in recovery for war-based trauma. Interestingly, moreover, the setting for the "Verona" of their Romeo and Juliet is not limited to the makeshift theater in the attic of this building in Amman, but it also extends to an undisclosed site in Homs. As the action unfolds, the tandem performances are mediated through a screen that divided and yet also connects the performers and audiences via Skype.

Fundamentally, theatrical drama can draw some interesting parallels with religious phenomena. On the other hand, the difference between religion and theatrical drama can become blurred so that the tension that holds them apart temporarily collapses. In an interview (Brook 1979), famed British theatre director and avant-garde student of the stage, Peter Brook characterized theatrical action in its truest form as "religious". He claimed: "The ancient theater clearly was, and theater must always be, a religious action: it is that by which fragments are made whole". For Brook, who does not believe "an entire society can heal itself, or be healed by one person or group of people", theatrical drama instead performs a crucial role and offers a potent medium for addressing open wounds of conflict, division, and fragmentation. As such, with these conditions, Brook acknowledged the requirement of a tragic element that dramatized political reality and the historical situation. In almost the same breath, however, he pivoted attention toward a proleptic quality that such events possess, when he stated: "The great force of artistic events is that they are temporary glimpses of what might be, and there is a healing process attached to these glimpses". ${ }^{3}$ With respect to these events, according to Brook, a group of performers and audience do not stand apart as separate. Rather, on occasion, theatrical drama brings them together "into a form of communion" when simply storytelling is "recognizable", which for Brook is to say, "like life". For his conversation partner, Brook elaborates this dynamic process, not of two groups "one watching and the other doing", but rather as a "progressive heightening through which the two worlds become more sharply perceived by everyone who is present". ${ }^{4}$ As such, by way of Brook's observations, there is a threefold sense by which theatrical action can be identified as "religious": for present purposes, we can identify these overlapping dynamics as "salutary", "anticipatory", and "communal".

For the sake of considering the case at hand: How does understanding "theatrical action" as potentially religious, in Brook's sense, shed light on this adapted performance of Romeo and Juliet? For Syrians, given the war-torn situation, how might this event provide a momentary sense of unity and even a "spiritual communion" either despite or enfolded within the exile, violence, division, fragmentation, and separation? What does this performance contribute about the tension between presence and absence? As these are some of the core questions underlying this inquiry, this article presents (re-presents?) an actual performance of Shakespeare's classic Romeo and Juliet in the form of a case study. As such, as outsiders, readers are asked to consider how we make sense of this adaptation, its appropriation of Shakespeare's famous tragedy and its unique amendments. Subsequently, the inquiry expands to introduce Frans van der Lugt S.J. (1938-2014), a Dutch Jesuit and Christian missionary in Syria, as a key figure to whom the revised script pays homage. For the Muslim-Christian matrix of this audience and performers, what may be the significance of such a gesture? Does this not encourage public discussion about theological matters? As a complex case in its own right, the possible identification of Frans van der Lugt as a Christian martyr bears theological and ethical implications,

3 See (Brook 1979). The interviewer is not named.

4 (Brook 1979, p. 48). 
and thereby complicates Muslim-Christian dialogue. The performance, however, ultimately provides a different angle upon van der Lugt and his example possibly contributes to the Christian understanding of martyrdom. Reframing martyrdom by Christological keys of witnessing, through case reasoning, this exercise of comparative theology learns from Ibn 'Arabī's theology of signs how witnessing truth fosters a more passionate affective response. Finally, as will become apparent, witnessing carries ethical implications. Theologically speaking, how do we witness to this performance and its aftermath? In the concluding reflection, this basic question is meant us into the performance.

As a foray into theatrical drama, overall, this case study affords an occasion for Muslim-Christian comparative theology. Thus, this article attempts to develop the basis for interpreting a dramatic moment as "religious" in the threefold sense that Peter Brook conveys. Moreover, implicitly, it contends that the discipline of comparative theology can be serviceable for such an endeavor, concluding that the performance may a glimpse of a radical and yet difficult hope. Ultimately, in the style typical of a case study, the goal of this article is to provide a starting-point for shared theological reflection between Christians and Muslims in virtue keys of solidarity, hospitality, and mercy.

\section{Acknowledgements: (Mis) Uses of Theatrical Drama for Muslim-Christian Understanding}

To this end, the discipline of comparative theology is serviceable given its attention to particularities, resistance to generalizations, and willingness to proceed dialogically. However, there are potential risks in employing theatrical drama for interreligious understanding. In approaching this special issue, let us consider some interlocking points in order to address how we have to do comparative theology.

First of all, there is a strong tendency for North American and European perspectives to characterize the Middle East as a whole and its various parts, including Syria, with the metaphor of "political theater". In the context of Islamic studies, perhaps no one has so masterfully pointed out the consequences for misunderstanding Islam as Talal Asad. In his seminal lecture, "The Idea of an Anthropology", he suggests, this stylized use of "political theater" might actually deflect us from reckoning with some critical questions. ${ }^{5}$

Nevertheless, being so culturally embedded, theatrical terminology and dramaturgical methods can also preserve interreligious misunderstandings. He critiques the particularly "dramatic" quality of anthropological portraits of Middle Eastern (read: Muslim) politics. If one turns to Ernest Gellner's mechanistic interpretation of Islam as a network of "social causation" or Clifford Geertz's more "dramaturgical" perception of Islam, as Asad states: "What one finds in effect are protagonists engaged in a dramatic struggle". In those representations, a reader finds various tribes, armed nomads, the mediating saint, embattled clerical literati, the religious fervor of the city's poor, religious reformers, and demoralized rulers as, Asad critiques, a "representation of social structure that is cast entirely in terms of dramatic roles". Regardless, whether this poses a viable means of description and as illuminating as it may be, Asad fundamentally objects to how such narrative lacks "an account of the discourses that orient their behavior and in which behavior can be represented (or misrepresented) by actors to each other". For instance, Gellner's actors are without words, Asad notices, "they do not speak, they do not think, they behave". In the end, one may get the false impression that Islam is simply reducible to an intricate choreography about power, or, to borrow his words, "as a drama of religiosity" and so Muslim conduct as merely a "readable gesture". ${ }^{6}$

Due to his history of misunderstanding, therefore, should we assume that theatrical drama must be cast aside? One could be inclined to interpret Asad's own position as negating or denying the usefulness of theatrical vocabulary. To be clear, this would be mistaken in two ways. On the one hand,

5 (Asad 2009, pp. 1-30); it is based on a paper originally presented at Georgetown University in 1986.

6 (Asad 2009, pp. 12-13). Asad is critiquing (Gellner 1981 and Geertz 1968). The latter work remains a classic in the field of Islamic studies. For Asad's main point: "The analysis of Middle Eastern political economies and the representation of Islamic 'dramas' are essentially different kinds of discursive exercise that cannot be substituted for each other, although they can be significantly embedded in the same narrative, precisely because they are discourses" (Asad 2009, p. 10). 
as already noted, Asad warns against a "fixed cast of Islamic dramatic personae". If dramaturgical method should be employed, in keeping with the metaphor of dramatic play, he might be read to stress as a minimal requirement that an account that should be composed of lines, those "very lines actors speak". ${ }^{7}$ Thus, as he urges, anthropological accounts of Islam as basically narratives themselves "must try to translate and represent historically situated discourses as responses to the discourse of others". ${ }^{8}$ Relatedly, when those voices direct attention "beyond the fixed stage of an Islamic theater", as Asad argues, they embody a particular way of enacting underlying sources of authority as "discursive traditions". As such, those figures of authority are also bearers of history who seek to instruct practitioners as actors regarding a "conception of what is apt performance". In sum, if Asad's approach still issues a forceful reminder of the challenges and problems concerning theatrical drama, as a conceptual metaphor, and particularly the repercussions for representing Islam, at the same time, he also concedes its usefulness for illuminating Islamic traditions.

From a comparative theological perspective, moreover, another point of learning that Asad's approach and scholarship may avail is indicative in his particular development of the notion of "apt performance". Notably, in Genealogies of Religion, Asad turns to The Rule of Benedict as a case-in-point, further developing the idea of "apt performance" specifically pertaining to a particular "programmatic text". Focusing on particular performance, as was his objective, opens multiple avenues into a set of "mediating practices". Nonetheless, concerning this Benedictine tradition, he wishes to disabuse his readers that meditations, chants, and-we might add-hospitality is not "theatrical", at least not "in the sense, to which we are now accustomed with all its implications of artful impersonation". Rather, he writes:

The program is performed primarily not for the sake of an audience but for the sake of the performers, who are learning to exercise and to develop the Christian virtues, to replace unlawful desires with virtuous ones, not to appreciate an aesthetic representation. ${ }^{9}$

Yet, thirdly pertaining specifically to the current issue, should we not be prepared to accept that theatrical drama has proven to be a very productive genre for Christians and Muslims in order to relate theological truths? Interwoven into the literary fabric and creative sensibilities, theatrical drama helps elucidate and make manifest religious realities. For Christians, the classic script about martyrdom seems to have followed the basic outline and template of the "Passions of the Martyrs Perpetua and Felicity", as the resistance of Perpetua (d.203) was staged as a spectacle in the Roman amphitheater. ${ }^{10}$ Inaugurating a new form of Christian narrative that enacted for its readers a defiant faith in the face of religious persecution, the text seemed to summon Christians in the Roman Empire to emulate their example. As for Muslims, on the other hand, heroic accounts of those who died courageously in battle against the aggression of the Qurayshī are enshrined in the biographical accounts (sìrah) of the Prophet Muhammad. ${ }^{11}$ As Michael Cook is right to point out, among Sunnis there is not "anything remotely so dramatic to aid in the commemoration of the martyrs" as the $t a^{\prime} z i y e h$ ("passion plays"), ${ }^{12}$ a tradition reinvigorated in the 1960s that rehearses and re-enacts the paradigmatic sense of suffering, sorrow, and redemption that the martyr's death of Imam Husayn (626-680) signifies. In sum, theatrical drama has proven integral for select discursive traditions of both of these religions.

At another level, fourth, theatrical drama might even disclose certain possibilities for interreligious understanding. Let us return, by way of illustrative example, to the observations of Peter Brook, who

\footnotetext{
(Asad 2009, p. 15).

(Asad 2009, p. 10).

(Asad 1993, pp. 140-41). For the Christian source of historical theology that Asad credits and from which draws in this exposition, see (Leclercq 1979).

10 (Musurillo 1972, pp. 106-31). For historical context, see (Heffernan 2012).

11 (Ling 1983).

12 See (Cook 2007, pp. 133-34).
} 
cites $t a^{\prime} z i y e h$ performances as the "most living form of mystery play that still exists". To illustrate the threefold sense of theatrical action, in 1979, he recalled,

I saw in a remote Iranian village one of the strongest things I have ever seen in theatre: a group of 400 villagers, the entire population of the place, sitting under the tree and passing from roars of laughter to outright sobbing-although they knew perfectly well the end of the story-as they saw Hussein in danger of being killed, and then fooling his enemies, and then being martyred. And when he was martyred, the theatre form became a truth-there was no difference between past and present. ${ }^{13}$

Many scholars of Islam, including Talal Asad himself, ${ }^{14}$ have tended generally to use these stories of the martyrdom of the first imams as a prime example of "ritual drama". As such, they have largely focused on how the performers and enactment, and largely neglected the audience. When audience is discussed, it is usually downplayed as aesthetics or chalked up "theatrical" to a less than ethical matter to "theatrical". What Asad's critical approach neglects is the event character of such moments. In effect, as Brook's account is meant to illustrate, by a work of theatrical action a theological truth is disclosed. As Brook himself recognizes, what these Iranian Shia villagers were witnessing is what he characterized as "an incarnation", which is to say, "at that particular moment [Husayn] was being martyred again in front of those villagers". ${ }^{15}$

Considering these points, I venture to suggest that "witnessing truth" provides in the multiple senses of the term an indispensable concept for developing the ethical implications of Muslim-Christian comparative theology. According to the renowned Catholic theologian Karl Rahner, witnessing not only "involves an intrinsic reference to someone else", as a manifest gesture witnessing signifies "that in which in which someone communicates himself and, moreover, by the most intense use of his own freedom in so disposing of himself that thereby a corresponding decision is evoked in some other person too" ${ }^{16}$ Although the term may conjure Christian missionaries, in juxtaposition to proclamation, Catherine Cornille argues a defining character of interreligious dialogue is "mutual witnessing", which presupposes the "possible presence of truth" in another religion and "the possibility of being captivated and compelled by the witness of the other" ${ }^{17}$ In this sense, witnessing is at its core a dialogical concept. For the sake of addressing the Syrian refugee crisis, in 2017, reformed theologian Joshua Ralston proposes "witnessing" as a theo-political framework for Muslim-Christian encounter as "an ongoing practice of bearing witness to God and God's coming justice". ${ }^{18}$

For consideration of this case, that is, an Arabic performance of Romeo and Juliet that is set between a hospice attic in Amman and a hidden theater in Homs, witnessing truth might invite shared theological reflection between Muslims and Christians. What is missing in Talal Asad's conceptual approach, according to Muslim theologian Martin Nguyen, is the "crucial role of the Divine in the unfolding of tradition". As such, theologians can account for the human role in constructing tradition, and also permit the possibility that it is "not merely about past and present, but about past and present in which God's working are manifest" ${ }^{19}$ By attending to this case, and given the ongoing Syrian crisis, the idea of "witnessing truth" not only provides a basic theological framework, it also an interpretive key that coheres this event between the performers and audiences and, furthermore, fundamentally accounts for its intercultural perspective and interreligious focus. If witnessing implies a progressive clarification of the truth, at the same time, it also should also become responsive to the demands of justice.

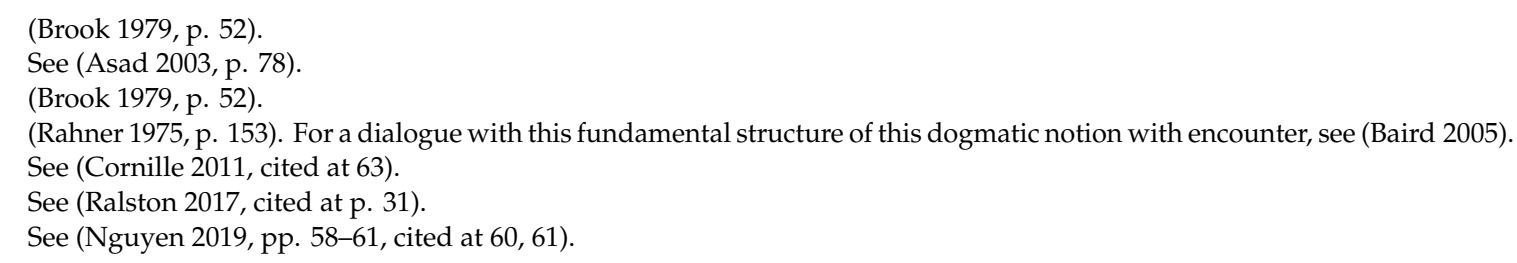


As this case illustrates, theatrical drama invites new perspectives and can shed light on theological questions. Being profoundly dialogical, theatrical performances require an audience. As this case suggests, it creates new space and demarcates a basis for fostering a commitment toward Muslim-Christian solidarity. As the performances incarnate an open illustration of the power of theatrical action to create new possibilities, as grounded as it is, the play also takes liberties to address Shakespeare to its particular political and religious situation. Although the play will seem to flout conventional rules for staging Shakespeare, on this issue, the adaptation remains quite faithful to a basic truth that in his wisdom - and perhaps especially through his tragedies-Shakespeare "forces us to regard any perspective on human actions as deeply provisional, historically bounded and contextually determined". ${ }^{20}$

\section{Reassembling the Scene: Adapting Shakespeare's Romeo and Juliet in Exile}

On 14 April 2015, an Arabic performance of Romeo and Juliet is set to stage for the fourth of what will be ultimately five performances. This run is extended from the two initially planned. In the attic of hospice for war-affected children, much of the primarily Syrian audience is constituted of patients who were carried up from their beds on the floors below. Others are themselves, like the director and actors, refugees from Syria who are living in Jordan as the Syrian civil war is entering its fifth month and when the bombardment is escalating in many parts of the country. Entitled Romeo and Juliet Separated by War, the production is the result of four months of rehearsals in this practice space, located above where four young actors are recuperating from their war wounds and trauma. From the original script, William Shakespeare's tragedy about "star-crossed lovers" provides a lens by which performers and audiences alike can observe the dilemmas that they are facing. While the script itself furnishes themes like family feuds, bloodshed, vengeance, this play concentrates upon the love and longing at the heart of the relation between Romeo and Juliet. Although implicit, still, the war is front and center and none needed a reminder from Shakespeare of the siege in Syria, "where civil blood makes civil hands unclean" (1.i.2). ${ }^{21}$ In this version, the Juliet and the "Capulets" perform in the shadows of secret stage in Homs, while Romeo and the "Montagues" are acting in Amman. In Amman, where a screen faces the stage and connects performers and audiences and, in turn, a camera captures the theatrical action in Homs for transmission to Amman. As for the satellite equipment that the production uses in Homs, according to rumor, it was a gift of the Syrian Free Army that had stolen it from the government.

The love and conflict at the core of Shakespeare's tragedy plays out as the action unfolds in this performance and, of course, is further intensified across this geographic divide. According to an eyewitness account, twelve-year-old Ibrahim, the actor who plays the young Romeo, had lost his mother and three sisters to government bombardment. ${ }^{22}$ For a year, he has lived as a patient at SAB. Several surgeries rescued his leg from amputation, and, for the majority of the performance, he traverses the stage on crutches. Disabled, he acts without the full use of his right leg. Nevertheless, for one of the play's crucial scenes, a duel with the "fiery" Tybalt, he tosses one of the crutches aside and wields the other as his "sword" to the applause of his audiences. Himself a native of Homs, Ibrahim is allowed to look homeward through this digital connection. Along with Romeo, the Amman audience encounters in Homs his Juliet, a thirteen-year-old girl, who is wearing a hijab and also a mask, which conceals and protects her identity from government surveillance. For Romeo, in Amman, in order to interact with Juliet he needs to face a screen as Juliet, trapped in Homs, returns his gaze.

20 See (Kottman 2013, p. 246). For a similar challenge to hegemony of Aristotelian tragedy, see (Burrow 2013, pp. 1-22). On the regnant theory of drama, see (Aristotle 2012); this theoretical approach seems to focus on doing as opposed to creating.

21 The in-text citations are to the critical edition of William Shakespeare's Romeo and Juliet (Shakespeare 1990) and follow the standard form of citation to the act, scene, and line.

22 See (Taneja 2015). This performance did not receive as much high-profile media coverage as Bulbul's 2014 production of King Lear; there are several reflections by observers available in English and French e.g., (L'Homme 2016). Some photographs and video stills are available online: https://www.bl.uk/collection-items/photographs-of-a-syrian-romeo-and-juliet-2015 (accessed on 6 April 2020). 
Written into this script are two narrators, one Homs-based and another Amman-based, who perform a couple of roles. The narrators not only help bridge the action between this spatial divide, they also moderate the technological disruptions. Often, already fragile, the internet connection is attenuated, and so the narrators attempt to moderate the technological disturbances that regularly interrupt the performance. The yearlong siege of Homs looms in the background. In one performance, exploding bombs, which were being dropped from Russian and Syrian planes, are audible as the sound reverberates and echoes faintly in the Homs video feed. During another performance, on at least one occasion, the audience waits as long as an hour for the action to resume. Without a reliable internet connection, circumstances sometimes demand patience. When reconnected, from Homs, the child-narrator vows, "I swear, if we are not caught by bombs or explosives, and if Juliet is not fired at by a sniper, we will still be here in the next scene".

Additionally, in this adaptation, Shakespeare's character of Friar Lawrence is renamed. At the start of the second act, the audience in Amman sees a young actor, disguised with a mask and wearing a cardboard crucifix around his neck. He assumes the name "Father Frans". In his scenes, a sketched crucifix hangs above. Through the Homs video feed, the performers and audience in Amman hear an organ solemnly accompany the actor as he prays. As the couple's sole confessor, the character in this version is an homage to Frans van der Lugt, a Dutch priest whose death in a besieged neighborhood of Hom's urban center coincides a nearly year to the date of these performances. In this version, after the first encounter between Romeo and Juliet, the action swiftly escalates to their secret marriage. Imagine, for a moment, the audience of Syrian refugees sitting in the attic of that Amman hospice, waiting with Romeo, as they behold Juliet's image as she is broadcast from Homs. Their exchanges and pledges of love attempt to bridge a vast divide, while periodically that fragile connection is interrupted without much assurance that it would be re-connected. On each occasion, the reality of war produces a sense that the audience is not simply a conscious, critical observer, but likewise is immersed in the drama unfolding before them. In the clandestine wedding scene, in Homs, Juliet kneels before Father Frans, and places a ring on her own hand. In Amman, with his vow, Romeo does the same.

What perhaps would be most notable to an outsider witnessing Bulbul's Romeo and Juliet would be the change in climax. Rather than following Shakespeare into the play's final act, the action comes to an abrupt halt. Instead of witnessing the series of tragic and misguided accidents that culminate in the deaths of the love-stricken protagonists, for a moment, the actors disrupt the escalating tensions and frenetic pace of the plot in word and deed. In this version, distinctively, the narrators also play a role by intervening occasionally in the action of the performance. It is the narrators, not the apothecary, who hand the vials of potion to Juliet and Romeo. There was no deception to confuse Juliet's family, no murder of Paris, no double suicide between the "star-crossed lovers", nor other tragic accidents that precipitate this "fateful" conclusion. Rather reimagined in light of the teachings of Father Frans, the couple does not venture unwittingly to the climatic violence and their eventual suicides. Rather, "to reflect Father Frans's message and the desire of all present for the conflict to end", 23 Bulbul revises Shakespeare's tragic conclusion in the third act. Drawing from the original text, with reference to the Friar Laurence's plot to marry them, the narrator states, "The good monk Frans described what he wanted them to do". Interrupting the narrator, however, Homs-based Juliet declares, "Not true!" Seizing that ill-fated vial of sleeping potion, she hurls it to the ground. In Amman, following her, Romeo does the same. For those in Amman, next, they watch a young girl, who is acting as one of Juliet's retinue and the "Nurse, steps forward, crying: “Enough killing! Enough blood! Why are you killing us? We want to live like the rest of the world!"

Immediately, the audiences erupted in applause. After this climatic event, the players steered the action to the "curtail call". As the actors acknowledged the audience, first, they turned to bow toward the impaired, recuperated, and exiled audience of Syrians in Amman, and then turned to bow toward

23 (Taneja 2015). 
those sitting in that secret location in Homs. Chants broke out in the attic of the hospice. On this evening, many in this primarily Syrian audience-the director included-reacted to the performance in tears.

If the Palestinian people are best described as a "telephonic" people, as Mourid Barghouti ${ }^{24}$ put it in his memoir to characterize the diaspora as a network of disembodied voices, Syrians may find some poetic resonance in the fragile, virtual, attenuated, interrupted communion that survives despite separation this performance attempts to convey. The appearance of "Father Frans", on the other hand, also raises questions regarding the figure behind the character, whose influence presumably shaped this adaptation. What might this performance suggest about him and his character?

\section{A Key Player Remembered: Frans van der Lugt's Vita in Summary}

As a beloved figure in Homs, in the most basic sense, the performance offers a way of introducing the story of Frans van der Lugt. In some respects, his is a familiar one. Born into a wealthy family in Den Haag, Netherlands, on 10 April 1938 van der Lugt received his schooling through Jesuit education until he entered the Society of Jesuit as a novice in 1959. Once in the novitiate, he undertook his philosophical studies in Nijmegen through 1964, after which he was assigned to missionary fieldwork in Lebanon. In Bikfaya, he studied Arabic and was eventually transferred to work at a Jesuit secondary school, St. Jean Damascène in the Homs neighborhood of Bustan-Diwan in the late 1960s. During his theological studies at the Jesuit scholasticate in Fourvière (Lyons), he earned a graduate degree in psychology. In between another advanced degree in psychology, he returned to the Levant. As his adopted home, Homs became the place where he initiated a range of ministerial services to meet the needs of not only Christians but also Syrians as a whole. His story, in short, is a biography of a European Jesuit missionary assigned to fieldwork at moment of significant religious and cultural transformation. ${ }^{25}$

If the Second Vatican Council represents a specific theological event that for Catholics, as Massimo Faggioli claims, "teaches us to look at the global and cosmic katholon, but especially to understand the global and cosmic through the poor, through 'the margins,'"'26 the life of Frans van der Lugt might yield important lessons. A few idiosyncratic aspects may distinguish his own vocation. For instance, while in Belgium for his tertiate formation in 1974, he began to develop an interest in Zen meditation, a practice not typical for his missionary province in Lebanon and Syria. Once back in Syria, he became an active organizer and exponent of developing communities and care facilities for the mentally disabled, adopting the L'Arche model which Jean Vanier founded in Trosly, France. Outside Homs, he established an institute called al-'Ard ("Earth") that focused this mission locally as it developed to serve roughly fifty disabled people from nearby families, both Muslim and Christian. The center became the site for Muslim-Christian service that was directed toward environmental problems. A central component of that organization was Dar al-Salām ("the House of Peace") where all were invited to develop their spiritual practice. Five years later, in Damascus, he replicated this mission under the aegis of L'Arche. Through these initiatives, Frans van der Lugt helped bring Muslims and Christians together through concrete projects of collaboration and social justice.

For Syrians, probably, the most distinct of van der Lugt's many initiatives was a youth-focused endeavor, which he developed under the simple title of al-masir ("the hike"). For Muslim and Christian youth, whether a daily excursion or an eight-day retreat, he created and operated an interreligious space that was mobile. Customarily, he offered daily mass, to which Muslim youth were invited, while the shared contemplation and reflection often took the form of Zen meditations. For this and other endeavors, regardless of religious identity, many Syrians referred to him as Abouna Fransis ("our Father

24 See (Barghouti 2000).

25 For a timeline, see (Begheyn 2015, pp. 12-14).

26 (Faggioli 2013, p. 816). 
Frans"). What is particularly striking, in sum, is how van der Lugt fostered and exemplifies a dialogical and an interreligious commitment into his Jesuit identity.

A possible reason for the relative neglect of his story might be that he lies in the shadow of other Jesuits. Within the Society's Near East province, in recent decades, fostering a commitment to dialogue and interreligious collaboration has become a key apostolic goal. Prominently, for example, the Italian Jesuit Paolo Dall'Oglio, who received his degree in Islamic studies and has written widely on Islam from a Christian perspective, revived the monastery Dar Moussa as a place of interreligious hospitality prior to his abduction in 2013. ${ }^{27}$ For the Syrian context, in contrast, van der Lugt's narrative may appear too simple and ordinary. On the other hand, given the magnitude of the Syrian crisis, his role might also seem marginal at best. Amidst increased bombardment, during the season of Lent in 2012, he gave witness to a Dutch readership of the interreligious solidarity as several dozen Syrians were becoming like a "family". As the children of an Orthodox family sit in the front row during the Palm Sunday mass, he asked the Muslim imam living with them to read a passage from the Qur'ān. As Easter approached, for his readers, van der Lugt remarked how seamlessly his Muslim neighbors encountered this basic structure of death, life, resurrection ("Dood, leven, verrizen"). What van der Lugt admires most in them is how refugees are so well received, simply stating: "The parable of the good (barmhartige) Samaritan is in their blood". ${ }^{28}$

Nevertheless, over the course of twenty months, van der Lugt continued to carry out his ministries to Christians and Muslims. As the fighting intensified in Homs, at the turn of 2014, the United Nations exhorted foreigners to evacuate before or by February. When 1400 foreign nationals did evacuate, van der Lugt chose to remain despite the siege, with his own decisive commitment made to advocate on behalf of those Syrians still entrapped in Homs. Explicitly challenging the international community, in both French and Arabic, he initiated a series of YouTube broadcasts so as, from these margins, to be explicitly "representing the Christian people of this area" and also to address his global audience on behalf of their Muslim neighbors. Although they were enduring this suffering, he proclaims, they did not want to die of starvation, and they endure with a "divine patience". Later, amidst increased bombardment, on 6th April 2014, van der Lugt wrote to a Facebook community of Syrians scattered throughout the diaspora. In that final message, he witnessed how faith could help them bear these difficulties, "to be patient and to continue to hope". In concluding his meditation, he also shared their anticipation of "Easter, reflecting on crossing from death to resurrection". In that brief missive, he expressed, "Light shines from a dark cave feel like we are in the valley of the darkness, but we can see that light far away, leading us to life again ... We wish this resurrection for Syria". He signed off with his distinctive slogan "ilā' al-amām" to console and encourage his companions "forward, onward". ${ }^{29}$

On the next day, 7 April 2014, that is, two days prior to Palm Sunday, a masked gunman-whose identity and motive still remain unknown-forced his way into the Jesuit residence in Bustan al-Diwan. After van der Lugt was pulled into the atrium of the modest complex, he was shot twice.

Immediately, in reaction, the archbishop of Nijmegen declared van der Lugt a "martyr". Before a general audience in the Vatican on April 9, Pope Francis invoked his name as a reminder of the widespread suffering in Syria. In the same atrium where van der Lugt encountered his death, his funeral ceremony drew not only fellow Jesuits, neighboring Christians, but also many Muslims, including Sunni and Shia imams. In Homs, mourners gathered around his simple burial site in the garden of the Jesuit residence. To the extent possible, spontaneously, this site has served as a pilgrimage destination for a number of Syrians. For days, both Christians and Muslims prayed at his tomb. At the grave, one Muslim woman who identified as Joumana reveals, "I confided my secrets and he consoled,

27 (Montjou 2006). For useful cultural context of this movement, see (Loosley 2008).

28 See (van der Lugt 2012). This article's title can be translated as "Joys and Sorrows from Homs". For a reprint, see (Begheyn 2015, pp. 63-70). The Dutch term barmhartige is better translated specifically as "merciful" or "compassionate".

29 The original Facebook post has become deactivated. For a reprint, in Dutch, see (Begheyn 2015, pp. 75-76). 
he was a priest for me". ${ }^{30}$ For diasporic Syrians, his name subsequently became a place to gather virtually and literally offered a source for mutual veneration between Muslims and Christians.

\section{By Way of Analogy: From Christian Witness to the Crucified Peoples}

As a complex case in its own right, embedded with this adapted performance, the example of Frans van der Lugt poses a challenge for Muslim-Christian comparative theology: How do we make sense of his complex theological performance? The first aspect of this challenge regards the Christian tendency to evaluate Christian martyrdom in terms of persecution and a restrictive conception of the term. The second is how to relate the settings and theologies of people who inhabit radically different political and religious situations. Given the apparent interreligious significance that he seems to bear, the question about how we characterize Frans van der Lugt matters inherently from a Catholic standpoint.

Based on a specific set of assumptions, Christians may be predisposed to a specific way of interpreting the case of Frans van der Lugt in terms of persecution. Consider, for instance, the opinion of the distinguished Catholic journalist John Allen, Jr., who asserted shortly after van der Lugt's death that he should become the "patron saint of persecuted Christians". As he tells us, due to his profile, van der Lugt's name made the headlines when others never do. Similar cases abound, he claims. ${ }^{31}$ For Allen and others, theologian Lawrence Cunningham confesses, the sheer difficulty to imagine martyrdom otherwise: "[it is] very difficult for me to bracket the nearly two-thousand history of the memory of the Roman martyrs". ${ }^{32}$ On the other hand, others may wish to stress van der Lugt's importance as a figure to promote a human rights agenda. However, it matters how those images either exclude or embrace certain persons. At one extreme, we might suppose, the risk is that his name is rendered so as to make its meaning unrecognizable form his life as lived and, at the other, to dilute his purpose in a way that robs his example of its special theological power.

As a general rule, from an ecclesial perspective, the core criterion for determining Christian martyrdom is death "out of hatred of the faith" (odium fidei). In other words, as typically stressed, the recognition of a Christian as a martyr depends on the motive of the murderer. Moreover, this stance presupposes that the martyr accepts death voluntarily. Much has been written of this internal Catholic debate that will not be reproduced here. Rather, it should be asked: But how closely does this narrative tradition and its conception of martyrdom resemble the case under consideration? Concerning the particularities of the case of Frans van der Lugt, it seems, there are a number of problems. At this point, for instance, it is impossible to ascertain the murderer's motive. The notion of an act of martyrdom, moreover, seems to overemphasize death at the expense of a wider scope. Plus, if both the funereal visitations and the performance are any indication, Syrians honor him for more than his violent death. Such a conception, furthermore, seems to highlight religious otherness at the point of violence and then to disregard otherness when shifting from moment to death to theological implications. Theological speaking, how might we respond to this penchant and also to the novel issues that the van der Lugt case poses? Case reasoning itself might offer a mode of reflection to identify similarities to standard and relevant cases that shed light on the distinctiveness of cases that present novel problems.

Responding to the political and religious reality in El Salvador specifically and Latin America more widely, the Jesuit and liberation theologian Jon Sobrino perceived a "paradoxical situation". Based on the set of assumptions regarding martyrdom, as outlined above, Sobrino observed that there are those who are attempting to live out the gospel and who model what it means to incarnate Jesus'

30 See "Pleurs et prières autour de la tombe du père Frans, le 'saint' de Homs", L'Orient Le Jour (16 May 2014), p. 10. Available online: https://www.lorientlejour.com/article/867509/pleurs-et-prieres-autour-de-la-tombe-du-pere-frans-le-saint-de-homs. html (accessed on 6 April 2020).

31 (Allen 2014). For a scholarly project with a maximally broad definition of Christian martyrdom, see (Johnson and Zurlo 2014); van der Lugt is cited on p. 682.

32 See (Cunningham 2011, p. 13). 
mission and yet the church does not deem martyrs because they are killed by those who are nominally or at least believe themselves to be Christian. Since Karl Rahner argued for a "certain broadening" of the Christian conception of martyrdom beyond the restrictive sense, ${ }^{33}$ the topic is the subject of a well-chronicled debate within Catholic theology. Plus, as Ernesto Valiente proposes, the contributions that Sobrino's work offers is better understood in the context of Christian discipleship. ${ }^{34}$ For the case under question, I want to outline briefly how similar cases help reframe the question of martyrdom in Christological terms of witnessing.

For Sobrino, first of all, the general rule determining Christian martyrdom did not fit the circumstances of the Salvadoran reality. Instead, in Jesus the Liberator, he argued the priority should be the choice of "setting". For him, the war-torn situation of El Salvador in the wake of its own civil war provided the hermeneutical backdrop for his reconsideration of Christ, martyrs, and the challenge of justice. As far as his theological agenda is concerned, it will have to suffice to summarize as he does: "from the standpoint of the poor we think we come to know Christ better, and it is this better-known Christ, we think, who points us to where the poor are" ${ }^{35}$ To this end, particular figures become vital as interpretive keys for this hermeneutical circle.

As a major example, the Salvadoran Archbishop Óscar Romero (1917-1980) provides another relevant case by which reframe the theological question of Christian martyrdom. It was in light of Romero's example that Karl Rahner posited a fundamental distinction between the classical conception of Christian martyrs and one emergent through such significant figures. Whereas the former reflect a "passive" sense of "endurance", the latter are engaged in an "active struggle", that is marked by "a supreme act of love and fortitude". ${ }^{36}$ From El Salvador, following Rahner, Sobrino also sought to highlight such "non-poor" intermediaries who through their witness to the "situation to the poor" exemplify how setting operates by "allowing oneself to be affected by it". ${ }^{37}$ Turning to an example like Romero, Sobrino claimed that there are "innumerable martyrs who have given their lives out of love and who are still present and active, and this helps us understand the martyr Jesus who was raised from the dead". 38

Understanding martyrdom in terms of Jesus' death does not focus exclusively on the cross, as Sobrino teaches, rather the example of martyrs sheds light on Jesus. In this manner, Sobrino starts to retrieve the Christological roots of martyrdom, as evidenced particularly in the gospel narratives. In Jesus the Liberator, at times, Sobrino supposes theatrical language may imply heresy and, at its worst, distance a praxis of justice from real inequities. ${ }^{39}$ On the other hand, it does begin to capture the disposition of denunciation by which Jesus addresses hope and the situation of the poor: "In systematic language, Jesus has the audacity to proclaim the outcome of the drama of salvation, the overcoming, at last, of the anti-Kingdom, the unequivocally saving coming of God". ${ }^{40}$ In Christ the Liberator, having identified Jesus as the "definitive witness", ${ }^{41}$ Sobrino elaborates how Christian "praxis", by which he means all those activities Jesus used to transform social reality in the direction of the Kingdom of God, while "unmasking" the anti-Kingdom.

By way of analogy, according to Sobrino, certain examples cast a similar figure through their "call to struggle against the anti-Kingdom". ${ }^{42}$ Just as the disciples see themselves as "witnesses" (Acts 2:32), similarly, these figures model an "imitation of Christ" (imitatio Christi). Like Jesus, in life and death,

33 (Rahner 1983).

34 See (Valiente 2014).

35 (Sobrino 1993, p. 35).

36 (Rahner 1983, p. 10). Sobrino credits Rahner for paving the way for this understanding of Christian martyrdom from a Latin American perspective.

37 (Sobrino 1993, p. 30).

38 (Sobrino 1993, p. 8).

39 See, e.g., (Sobrino 1993, p. 118).

40 For uses of "drama" to describe Jesus' praxis, see (Sobrino 1993, pp. 76, 118, 239).

41 (Sobrino 2001, p. 137).

42 (Sobrino 1993, p. 116). 
these figures shed light on both the identity and relevance of Jesus for the present political and religious reality. So Sobrino asserts: "therefore, theologically, those who today bear witness with their lives to God's Kingdom, like Jesus, are martyrs and in them we find the analogatum princeps of martyrdom". ${ }^{43}$

In 2018, Pope Francis canonized Romero as a saint. For Sobrino, the importance of this figure is that "when we call these victims martyrs, we mean that they reproduce the life and death of Jesus and they shed a great light". In a fundamentally relational sense, thus, Christian martyrs point toward a wider "constellation of witnesses" according to Sobrino, specifically to "all of those who today resemble Jesus by living and dying as he $\mathrm{did}{ }^{44}$ In his view, as a "dynamic sacrament", the poor as victims also call Christians to conversion. If Romero' case exemplified "martyrdom in terms of the anti-Kingdom's response to those who struggle actively for the Kingdom", the case of those who "unprotected masses, who are put to death in huge numbers innocently and anonymously" reveal martyrdom in terms of "bearing the sin of the anti-Kingdom". In this sense, Sobrino refers to them as "martyred people". ${ }^{45}$ In Christ the Liberator, he adds: "And when we call these victims martyrs, we mean that they reproduce the life and death of Jesus and they shed a great light" ${ }^{46}$ It in this context, that Pope Francis's appeal to Syria from the memory of his fellow Jesuit to Syria as a whole is understandable, as he identifies, Syria as "my beloved country" and a "the crucified people". In this respect, turning to "victims", they seek to discern a "difficult" hope between death and life.

Regarding the case of Frans van der Lugt, how close does he resemble this standard case?

Of course, his case is not identical with Romero's. In Christ the Liberator, Sobrino assumes his reflections by suggesting a point about the finite and limited nature of all interpretations, and his "as an essay" and so "to write from the reality of faith, set in motion by the event of Jesus Christ, and from the situation of victims at the present time". Although his reflections are grounded and set against the backdrop of El Salvador, he explicitly acknowledges that new Christological essays such through interreligious dialogue "introduce various forms of otherness into christology, not only that generated by oppression". ${ }^{47}$ Precisely with respect to this issue, the witness of Frans van der Lugt commends fellow Catholics to reconsider their Muslim neighbors as those who give witness to God's mercy. As such, we shall turn from witnessing truth in the dramatic examples of Christian martyr to witnessing truth in the "shadow-play" of divine self-disclosure.

\section{Towards a More Receptive Heart: Witnessing Signs of Mercy in Dialogue with Ibn 'Arabī}

For Muslims, the meaning of "witnessing" bears profound theological import and ethical implications. Of course, when they recite the bismillah in salāt prayers, Muslims witness liturgically to God's mercy and compassion. Concerning Muslim-Christian relations, the term has also become a source for misunderstanding. In dialogue, witnessing permits the kind of nuance and opportunity to address mutual misunderstandings. "To engage in witness, then, is also to challenge and correct false witnesses", Joshua Ralston contends, "and to invite one another into dialogue and dispute in the 'most virtuous manner' (Surat al-'Ankabut, 29:46)". ${ }^{48}$ In the context of Muslim-Christian dialogue, the term shahid tends to be associated with martyrdom on the battlefield. However, this hardly exhausts the range of meaning and depth that the term carries.

In 1890, as a matter of fact, Shakespeare's Romeo and Juliet debuted in Cairo under the marquee as Shuhada al-gharam ("Witnesses of love"). ${ }^{49}$ Some Muslims and scholars of Islam have seen this play as traversing comparable terrain as that of Layla wa Majnūn, that classic Arabic fable of a lover driven

\footnotetext{
(Sobrino 1993, p. 268).

(Sobrino 2001, p. 340).

(Sobrino 1993, p. 271).

(Sobrino 2001, p. 8).

(Sobrino 2001, p. 2).

(Ralston 2017, p. 33).

99 For background of this production and Arabic reception-history, see (Bayer 2007).
} 
into madness for the beloved. As the love between the couple is related, many will hear a praise of God as the creator of such love and beauty. The term itself, moreover, is not limited to a "martyr", but is embodied more widely and diversely as a literal witness to God's mercy. In the quranic usage of shahīd, the "martyr" connotation rarely occurs and the basis is tenuous. ${ }^{50}$ Within the Qur'ān, on one occasion that is especially pertinent for Muslim-Christian solidarity, the call to witness emerges in the context of the "ahl al-kitāb (an honorific term for Jews and Christians as "People of the Book"). The authorial voice urges Muslims to reach out, inviting all to "come to a common word". Yet if 'ahl al-kitāb should turn their backs on God, that is, "if they turn away, say, 'Bear witness that we are muslimūn" (Q 3:64). The objective here is not to provide a vast survey, more modestly, rather in what follows let us consider how a distinctive way of Islamic thinking cultivates an affective response.

Take, for example, the notion of "witnessing truth" that Ibn 'Arabī develops in Fusūs al-Hikam ${ }^{51}$ specifically one of the central chapters called the "Fass of Shuayb". ${ }^{2}$ As the Shaykh al-Akbar (the "Greatest Master") explains in this chapter, the heart of the one who knows is like the "setting of the stone of the ring", and that setting corresponds, conforms, and accords with whatever shape the stone itself has. If the basic concern is attaining human wholeness, each chapter explores the perfection of the figure from it draws its inspiration. For investigating the "wisdom of the heart", as James Morris notes, his specific chapter has served as a locus classicus for the essential question of discerning the human "face", that is, whether to turn one's face toward or away from God. ${ }^{3}$ As with most of his probing reflections, it is a work impossible to summarize. At a point of departure, as he explicates, witnessing is a condition that is acquired through a wisdom that is derived from diviner mercy. In the chapter, he guides his readers through the dynamic interplay between God's self-disclosure and the "heart of the knower". Accordingly, Ibn 'Arabī is elaborating theologically the various meanings of "signs" $(\bar{a} y \bar{a} t)$ that the Qur'ān proffers. First, in the basic sense, this refers to the quranic self-reference to verses themselves as signs of deeper meaning. Second, it refers to the potentiality of what might be deemed "cosmic phenomena" to reflect divine reality. Third, with respect to the one who would inquire, it connotes the self-understanding of the seeker. This ambiguity is deepened, when the term "witness" is drawn upon not only to conjure the one who is seeking God as the beloved, but also to articulate a divine attribute of God, namely "the witness" (al-shahid $).{ }^{54}$ As each chapter reflects a different form of receptivity, the work elaborates a deepening sense of the religious reality as a "shadow-play", the metaphorical image that Ibn 'Arabī employs to guide the seeker in this spiritual discipline of perceiving between light and shadows, the seen and unseen. In similitude, he evokes suggestively, a dramatic sensibility to these actual occasions of divine self-disclosure.

For his readers, Ibn 'Arabī showcases the heart in this specific chapter. Like a stage for this "shadow-play", the heart is drawn into an act of "unveiling" (kushf). Occasions of such divine manifestation, as Ibn "Arabī sets forth, the heart "expands" and "contracts" as the play alternates between unveiling and witnessing. In moments of unveiling, as Ibn 'Arabī states: "He raises the veil between Himself and the servant and the servant sees Him in the form of his belief". Recognition of divine self-disclosure comes to mirror the very content of the knower's witnessing. At the crux of the chapter, as it is revealed, inquiring into the meaning of "witnessing" is itself a function of what the Qur'ān prescribes in Surah Qāf: "Surely there is a reminder in that for whoever has a heart, or gives an ear attentively, while he is witnessing" (Q 50:37). Nonetheless, readers may notice an appreciable acceptance of play. Take, for instance, how the name Shuayb itself becomes a site for wordplay. The

50 For a useful overview of the term shahìd and its variants, with suggestions for further reading in the secondary literature, see (Rippin 2005; Kohlberg 1997).

51 There are several reliable English translations: see (Austin 1980; Dagli 2004; and Abramamov 2015). Translated passages are Austin's, unless otherwise noted.

52 Many Muslims claim that Shuayb is the biblical figure Jethro. For a thorough discussion of scriptural references and allusions of each chapter in Ibn 'Arabī's Fusūs al-Hikam, see (Chittick 1984).

53 (Morris 2005, pp. 131, 333 n32).

54 This divine attribute is used in the Qur'ān on several occasions (see, e.g., Q 85:9). 
name is rooted in Arabic with connotations of branching ( $\left.\operatorname{tash}^{\prime} i b\right)$, diverging, and so Ibn 'Arabī uses this to point how each "belief" has a particular pathway. For him, this pertains specifically to the inspired state that each prophetic figure represents in each chapter. Regarding the wisdom that coheres this chapter, as a reminder, the verse elucidates the careful process of discernment. Regarding all the diversity of forms of divine self-disclosure, if one possesses a heart, witnessing happens. Just as in prayer, when one listens, so too witnessing happens. By attending carefully, Ibn 'Arabī's readers are shown momentary glimpses into divine mercy that shapes and perfects the heart as alternating between unveiling and witnessing (shuhud). In the Akbarī sense, witnessing is not to be confused with a developmental spectrum, rather it establishes as a particular spiritual "station" that opposes the state of "heedlessness".

By contemplating this sense of witnessing truth, in the concluding reflection, Ibn 'Arabī identifies the movement of divine mercy that courses through reality as like breathing. Rather than alternating between inhalation and exhalation, however, he elevates the relation between "Lord" and "servant" as a "mutual dependence" insofar it is divine mercy breathing out in creation and, simultaneously, being inhaled from creation. For Ibn 'Arabī, one might presume, as with most cases, that the dead are more fully aware of this reality than are the living. In kind, carefully attending to the transmutation of divine mercy into all of its multiplicity of forms can shape the heart of a servant. It is an insight that, analogously, may elucidate a "constellation of witnesses".

The comparative theological tactic usually is to return to a Christian source, typically, a text in order to show how the non-Christian source sheds new light. Indeed, regarding Sobrino's retrieval of Christological roots of martyrdom, such a move can be fruitful. Sobrino himself suggests two martyrdom traditions in the New Testament, the Pauline and the Johannine. ${ }^{55}$ This heartfelt sense of receptivity, correspondence, and mutual dependence can highlight the prototypical characterization of the Jesus as "witness", a martyr that Luke portrays as not quite like Socrates, rather in a "long lines of martyrs", whose innocence and equipoise cannot be for one who "cheerfully accepted poison" ${ }^{56}$ Consider how, like Jesus, Stephen the one whom Luke describes as "witness" (martos), utters, "Lord, receive my spirit" (Acts 7:52). It is an echo of those unforgettable words Luke places on the lips of the crucified Jesus, "Father, into your hands I commend my spirit" (Lk 23:46). Alternatlvely, by returning to Sobrino's theology of martyrdom in light of Ibn 'Arabī, the key question shifts: From "How should I as a Christian disciple bear witness to truth in the face of this anti-Kingdom injustice?" to "How could these signs of mercy and compassion be received?" In other words, critically, the Akbarī notion of "witnessing" unveils and deepens an affective response. Thus, out of solidarity, this exercise returns to that crucial scene to read whether if offers a momentary unity between audiences and performers. To this end, the performance itself can serve as a foundational source for Muslim-Christian comparative theology, the goal of which is to critically stimulate a deeper case discussion. In a key of mutuality, Christians and Muslims could assist each other in reading them correctly.

\section{A Theological Reprise: Romeo, Juliet, and the Crucial Moment of Truth}

Theologically speaking, how do we witness to this performance and its aftermath? As of this writing, government forces have entrapped one million internally displaced Syrians in Idlib province. Millions more remain in exile, whether from Jordan and Lebanon to Germany, Turkey, and Greece. In the United States, over the course of the last few years, only a few hundred Syrians have received asylum as refugees. Aware as this essay is of its location, it must point out the danger of expropriating these child actors, their struggle, pain, and beauty, as a means to an end. Instead, a greater danger might be indifference as after nine years, cultural "fatigue" around the ongoing conflict may have

\footnotetext{
55 (Sobrino 1993, p. 265).

56 For philological examination, see (Strathmann 1967). For debate of this issue in academic literature criticism, see (Talbert 1982; Sterling 2001; Tabb 2015).
} 
become habitual. Taking the performance itself as the "foundation" for this concluding reflection, thus, the goal is twofold: in the spirit of theatrical action, as Peter Brook, it is to render that crucial moment in the communal sense, specifically, to lend a "temporary glimpse" with a vision to "to make whole"; and secondly, to foster a commitment to Muslim-Christian solidarity through this work of theatrical drama to cultivate empathy, exercise mercy, and recognize the signs of hope.

While as a comparative theological reflection risks expropriating, the performance itself poses features potential risks. Chiefly, to what extent, may the director Bulbul manipulate or exploit these child actors, using them as a means to end? Is this performance used to score political points? On the other hand, due to the perilous situation in Homs, the child actors risked their own lives in order to rehearse and participate in the production. In secret so as to avoid government surveillance, on a daily basis for four months, these four actors crossed the frontlines of the war on their way to the hidden theater. ${ }^{57}$ At a different scale of power, for further consideration, how could the use of Shakespeare possibly blind the case discussion to dynamics of cultural and power in Arab culture? ${ }^{58}$ How can Christians and Muslims work on the basis of such a performance to ensure flowering of creative expression without such artistic practices contributing to the erasure of Arab culture? ${ }^{59}$ Based on this case, these are a sample of urgent questions that may be raised in addition to those already considered. A priority, however, should be placed on a basic question: Who concretely stands to benefit? Turning to the basic reason and the manner in which Nawār Bulbul and his actors appropriate Shakespeare's tragedy is illuminating not only for the suggestive style it refers to the dark corners of their political reality but also that, in spite of it all, how it focuses upon the love remaining at the core.

How could art and theatrical drama more specifically be helpful for displaced people and especially these war-affected children? As a theatrical mediation of the crucible of tensions that define so much of Syrian experience, Bulbul's productions are experiments in "drama therapy". For juvenile and traumatized actors, whether living in the Za'atari, recuperating in the hospice, or besieged in Homs, "drama therapy" addresses a basic need in a context that is lacking educational resources and basic care for mental health. Although the process of drama therapy is complex, as he explicates through a communications strategist, Bulbul's commitment is "to humanize and inspire children through art" ${ }^{60}$ Standing on the basic notion that theatrical arts can transform war-affected children in Za'atari, this specific play offers specific indications of the benefits. For instance, consider how Ibrahim, the disabled thespian who plays Romeo, through the play is reminded that he is still connected to Syria, and more specifically his hometown of Homs. While reconsidering this performance, let us attend to how the adaptations suggest the kinds of dispositions and possibly even virtues this performance might engender in these actors.

\subsection{Shakespeare, Interrupted: Cognitive "Therapy"}

Due to a crisis setting of this performance alone, convincingly, the performance argues for the benefits of tactful appropriation of theatrical drama and selective use of tragic elements. In this specific sense, this adaptation might be grouped in concert with other unconventional performances of Shakespeare's well-loved tragedy about two "star-crossed lovers". Consider as another illustrative example how a Romany theatre troupe from Macedonia staged a political statement, as Anthony Dawson frames it: "Their Romeo was set in Bosnia, Juliet a Muslim and Romeo a Christian; the bombed-out ancient bridge at Mostar was used as a twisted balcony for Juliet, who spoke to Romeo

57 For an Amman-based observer account from a participant-observer, see (Pitchford 2019, pp. 140-43).

58 For a comparative theological model that accounts for a "third position", see (Stosch 2012).

59 For "developmental logics", see (Escobar 1995, 2008).

60 The theatrical project is self-funded. For a public appeal, see the crowdfunding campaign: https://www.kickstarer.com/ projects/331042491/syrian-children-play-romeo-and-juliet-separated-by. Hazami Barmada, a communications strategist, authored the letter. 
over the gorge" ${ }^{61}$ In this case, the religious identities of the actors are downplayed and yet the physical separation that exists in the two hundred miles between Amman and Homs is both emphasized and mediated.

If the purpose of this performance as a kind of drama therapy is for the children to inhabit as actors-albeit fleetingly and periodically—a different world, this involves learning different or new dispositions. In this regard, Peter Brook may provide an insight that differentiates theatrical action from ritual action. While ritual might involve actions that are programmatic and defined, "exercises" are radically different insofar as those actions "mean that as a beginner you do an exercise to learn". For example, taking "dance exercises" in a monastery, he suggest still, "doing those in the way they have learned, at that moment, present an open illustration, for anyone who wants to look at it, of what it means to be in touch with another level" ${ }^{62}$

In the case of Syria, Shakespeare's Romeo and Juliet seems to become so useful not just to illuminate the dark recesses of the political reality that this conflict imposes, but also primarily in order to highlight the love that survives despite it all. With the war and separation so present, this adaptation de-escalates the violence that permeates the original text in favor of focusing upon the insurmountable love between Romeo and Juliet. For those familiar with the text, it should be noted that this performance takes great effort not to remove violence from the plot, but rather to push it toward the margins. Noticeably, for instance, Romeo does not kill Tybalt, but disarms him. The skirmish in the public square of Verona that opens the dramatic tensions between the feuding Capulets and Montagues, in the original version, remains off-stage. Rather, as opposed to the mistaken signals that precipitate how the action unfolds in the original texts, the resilience of love is on full display as Juliet and Romeo declare loudly their desire to live.

\subsection{A Resurrection Appearance: Moral "Therapy"}

How can the example of Frans van der Lugt, a corpus of a different kind, be adduced in a role suitable to the way his martyrdom resonates with Syrian identity and may reconfigure Muslim-Christian dialogue? Although there is ample room for discussion, it should be based on the premise that there might be more truth between Christian and Muslim perspectives regarding his legacy than in Christian reflections alone. The appearance of "Father Frans", in a sense, invites a consideration of how his memory itself becomes a virtual space of healing for Muslims and Christians.

It is forgivable to find his character somewhat puzzling. Notably, consider how even his fellow Jesuit Jad Chabli, while delivering his eulogy at the funeral mass, commemorated his friend by way of critical questioning: "Why did you stay in Homs when you could have left, working with Jesuit companions who spend their days and a good part of their nights busy with refugees, to give them food? Why did you stay when you knew that you could save your very precious life that was always in service to the Syrian people whom you aided all the time?"63

For Catholics, according to theological ethicist Stephen Pope, Frans van der Lugt in his concrete actions teaches "inclusive character of Christian mercy", and specifically "a giving of oneself in a way that helps others appreciate their own dignity". ${ }^{64}$ Thus, he models a service ethic of compassion. Similarly, from a Catholic perspective, Hans Schaeffer recognizes in his "steadfast conviction" to remain in Homs a commitment that stems from "an agapeic love rooted in a relation with God, who is

61 (Dawson 2002, p. 186).

62 (Brook 1979, pp. 58-59).

63 The translation is my own: "Nous pouvons poser la même question à Frans: pourqoui es-tu resté à Homs quand tu pouvais en sortir, travailler avec tes compagnons jésuites qui passent leur journées et une bonne partie de leurs nuites à s'occuper des réfugiés, à leur donner à manger? Pourquoi es-tu resté quand tu sauvais que tu pouvais sauver ta vie très précieuse parce qu'elle a toujours été au service de peuple syrien que tu as aide tant de fois?"

64 (Pope 2015, p. 142). 
love". Such merciful actions, he proposes, "may function as a sign of hope in a world full of misery and evil". ${ }^{65}$

For others, for all of his simplicity, his example might illuminate a service ethics of hospitality. Even for those some of those closest to him, van der Lugt represented a walking paradox. Tony Homsy, for example, was once one of those Syrian youths who participated in the "hikes" with van der Lugt. Having become a Jesuit, he was studying in the United States when he learned of his elder confrere's death. Recollecting the jokes about van der Lugt, he highlighted specifically his meditations, and how they were Zen, not Ignatian. "But he was faithful, I see it now", confesses Homsy. "He was passionate about life, love and not fearing death. Full of joy. I see Christ clearly in him now. In deed more than in words". 66

Listening to these Syrian voices in their affirmation of love and life, furthermore, may underscore this point. Revised as such, Juliet cannot accept the narrator's account that it is Father Frans who suggests the scheme with the sleeping potion. It is noteworthy that no character is so maligned in Romeo and Juliet by reviewers and critics as Friar Laurence. Many take him to be either a pitiful victim of the plot or a naïve interloper whose attempt to help the two lovers actually determines their eventual demise. Unless one were not capable of a more generous spirit toward this character, his opening soliloquy may even inspire with his praise of the earth "and from her womb children of diver kind". Moreover, for the audience, he lays forth how the theatrical action that unfolds should be observed with humility, judicious vigilance, and also magnanimity and judicious: "Many for many virtues excellent, None but for some, and yet all different" (2.iii.10-14). The friar's own "bid" to redirect the impulses of the two protagonists and so to channel the play's passions, in the end, succumbs to the overwhelming pace and intensity of the action that unfolds. "By the play's end, of course", Michael Goldman critiques, "Lawrence's intervention has proved an example misapplied". ${ }^{67}$ As familiar as we may be with the original, however, this case does not represent the same character. Those scenes in the original do happen in this adaptation. Revising Friar Laurence's character and recasting him into the mold of "Father Frans" seems to irreversibly alter how the action unfolds.

From a Catholic point-of-view, Peter Brook's appreciation for the manifest presence of an "incarnational" moment speaks to the possibility of a deep truth this performance creates. Just as Imam Husayn emerges between the performers and audiences in $t a^{\prime} z i y e h$, a communion happens that is difficult to distinguish. "Nobody could draw the line between different orders of reality", Brook remembers, "It was an incarnation at that particular moment he was being martyred again in front of those villagers". In this case, possibly in kind, the performers and the audiences of this event may have registered this intensification of affect with the appearance of "Father Frans", only one year removed from the death of Frans van der Lugt may have experienced a similar presence. The basic appeal to this figure can pose a range of questions about the influence and power of such a reference that Brook's observation may not exhaust.

Resurrecting "Father Frans" in this way, however, might also present us with something of a paradox. For those in Amman, watching the Homs video feed, the body of the young masked actor evoked anew the presence of "Father Frans". If the performance creates a kind of presence, at the same time, it also enacts an absence. As he comments on the $t a^{\prime} z i y e h$ phenomenon, Talal Asad offers a different chord that may pertain to this case, remarking: "that who or what is represented in both absent and present at the same time (re-presented)" ${ }^{68}$ As a remembrance of the dead, how may the inclusion of Father Frans contribute a fuller awareness of the political and religious reality that these performers and their audiences must confront?

65 (Schaeffer 2018, p. 1).

66 See (Gilger 2014) and for his own reflections see (Homsy 2015).

67 See (Goldman 1972, pp. 33-44). This paragraph is clearly indebted to some of Goldman's insights.

68 (Asad 2003, p. 75). 
Nevertheless, when re-reading the original text in light of the adaptation, light is also shed on the original. How altered, for instance, is the sense of poor Capulet's regard for his beloved daughter Juliet as a "stranger in the world" and "the hopeful lady of my earth", an "Earth that has swallowed all my hopes but she" (2.ii.8, 14-5). So too, we might be forgiven for interpreting differently the moment when Juliet characterizes the friar in the form of "Father Frans" as her "ghostly confessor" (2.vi.21), or when the priest himself explains his own efforts to console the boy Romeo's anxieties about "banishment" as a "dear mercy" (3.iii.28). With other readers, we should feel invited to role-play these scenes, while bearing in mind the complexities and the novelty that this case poses to our self-understandings.

\section{3. "I Spy a Kind of Hope": Affective "Therapy"}

This leads us to the principal goal of "drama therapy", and how these child actors illustrate some of its benefits. In what follows, based on Brook's threefold sense and structure of theatrical action as potentially "religious" moments, I will propose what I take to be at least two signs of hope with three tentative and yet adequately clear lessons.

For Brook, recall, theatrical action can accomplish on occasion "temporary glimpses" that momentarily offer a radical shift in horizon between audiences and performers. In this moment, he suggests, a "healing process" is involved. Not only are such moments "salutary", in the holistic sense, they also become communal specifically between performers and audiences. With respect to this performance, conceivably, this climatic scene might provide a basis for the kind of momentary "reintegration" that Peter Brook has observed. By this, he refers simply to an occasion when this dramatic form furnishes a story and eventuates a performance with the audience "by the end of which everybody in it has actually, for a short time, experienced and tasted unity" ${ }^{69}$ Peter Brook is not naïve, as he acknowledged, soon thereafter performers and audiences alike return to a "society which re-fragments itself immediately". In the case of Syria, whether concerning internally displaced and besieged Syrians or those who are refugees, this reality is current and real. As Brook presupposes, something of this "reintegration" might still remain after the fact.

First, most obviously, the adaptation offers a radically different horizon for the performers and the audiences. Consider Juliet, for example. When she interrupts the narrator, she initiates a complete reversal of the actions that catapult the original play toward its tragic conclusion. In a meaningful way, rebuking the narrator's claim, her outburst revises the original text of the play. If we turn toward the scene as it develops in the original version, we find Juliet seeking consolation from the friar, as she exclaims, "O, shut the door, and when thou hast done so, come weep with me-past hope, past care, past help!" (4.i.43-5). In reply to such despair, Shakespeare's Friar Laurence offers his "remedy":

Hold, daughter. I do spy a kind of hope, which craves as desperate an execution as that is desperate which we would prevent. If, rather than to marry County Paris, Thou has the strength of will to slay thyself. (4.i.68-72)

In the revised version, Bulbul's Homs-based narrator paraphrases this exchange, implicating "Father Frans" in this stratagem to deceive Paris and Juliet's family: "His great idea was to give Juliet a bottle of sleeping potion that would make it seem as if she was dead". In the statement that follows, Juliet implicates the narrator as either a liar or an immodest judge of intention. At any rate, subsequently, the actors submit a declarative challenge: "Enough blood! Enough killing! Why are you killing us? We want to live like the rest of the world!" For the performers and audience in Homs, the connection to the audience outside the boundaries of Syria offers a moment that restores hope: their voices might be heard. In reply to this call, the performers in Amman echo this refusal of suicide, blood, and suffering.

69 (Brook 1979, pp. 50-51). Emphasis my own. 
Second, at the same time, this moment may suggest the belief that through theatrical actions these children have become transfigured. In Christ the Liberator, with reference to resurrection appearances in the Gospel narratives, Sobrino proposes, "there is no adequate language in which to formulate the reality of this event and experience of it". This poses a specifically hermeneutical problem with respect to a "language barrier". Still, based on the New Testament, he notices a plurality of basic linguistic models: life, exaltation, and awakening. Let me briefly exposit. "The language of life", he claims, "has the advantages of showing that death and denial do not have the last word in history, which belongs to affirmation and life, particularly when Jesus is said not only to live but to live 'always' (Heb7:24)" ${ }^{70}$ In a similar sense, conceivably, this might resonate with the collective declaration of the eight performers who shouted across the divide.

In a related sense, specific theatrical activities that led to this "salutary" moment might be more plentiful than can be observed. Still, Ibrahim, Bulbul's Romeo, may suffice as an illustration. At an earlier moment in the play, as Romeo, Ibrahim tosses aside his crutch in order to play-act with his other crutch. For him and the audiences, it offers an instructive scene of resilience. In the revised script, due to circumstances, Father Frans initially discourages Romeo from seeking marriage with Juliet; however, Romeo persists. In the Homs video-feed, through dialogue, Father Frans comes to accept and envision how the marriage can bring the Capulets and Montagues together. To close that scene, Romeo abandons his crutches and hops the stage, while expressing his gratitude to the priest. Given an allowance to play, experiment, and create through drama therapy, as actors, these children are invited to temporarily "inhabit" a different world. As a mediating approach, the practice of drama therapy seems to draw focus toward capabilities and hope, instead of impairment and despair. In other words, these children who are separated by the war are no longer identified in terms of victimhood but instead as actors. This may be the more enduring contribution of this short-lived adaptation.

Still, by witnessing this case, there are some clear lessons. If audiences take the performances of these war-affected children seriously, as with any devastating or tragic event, they may never be the same again. As for the performers themselves, through theatrical actions, they seem to inhabit for a defined period and in a demarcated after theatrical drama they may never be the same again. And yet if we look seriously at the performance of these war-affected children, we might find examples, all of whom decline temptations toward hopelessness and discover new creative capabilities.

As for Frans van der Lugt, in a sense, the performance "awakens" this figure. As if temporarily resurrected, the performance makes us look back and may even refers Christians and Muslims to the historical life of Jesus. In 2019, the Society of Jesus has postulated his cause for beatification, an initial ecclesiastical step toward canonization. After nine intense years of violence, Syria remains divided and fragmented, and yet Syrians wherever and however they gather may identify special significance to his name and memory. If the performance lends any indication, the play shows that van der Lugt might be part of a foundation upon which unity could be built in Syria, whether that is inside the national boundaries or beyond. Giving refuge to Christians and Muslims, he practiced hospitality despite extreme circumstances. For Christians and Muslims, who are outsiders, this extraordinary example may shed light on lessons for cultivating empathy, exercising mercy, and ordinary acts of affirmation.

Finally, from a Catholic perspective, this performance seems to present a hermeneutical principle analogous to one that Sobrino contributes from his Salvadoran context, namely, the "difficult" nature and "survival" character of hope. On the difficulty of such hope, he suggests, "it requires us to make the hope of victims, and with it their situation, our own". ${ }^{71}$ For Bulbul and his troupe of players are based in Amman and Homs, however, the emphasis is less on victimhood than it is on survival. Still, drawing on Romeo and Juliet, an inspired figure, and their own resilience, their performance indicate that hope is ultimately rooted in love.

70 (Sobrino 2001, p. 20).

71 (Sobrino 2001, p. 45). 


\section{Conclusions}

This case study, as an exercise in comparative theology, attempts to reassemble the structure and threefold sense of theatrical action creating a "religious" experience as Peter Brook observes especially in the $t a^{\prime}$ ziyeh tradition. From a Catholic perspective, first, it outlines challenges and opportunities for intersecting theatrical drama and religion specifically with concerns for fostering Muslim-Christian understanding. Thereby developing a lens for "witnessing truth", it approaches this case that, simultaneously, mediates tandem performances that are set in a refugee space in Amman and a besieged space in Homs. The performance encourages discussion of the late Jesuit Frans van der Lugt, whose life and death this case study examines for his potential contributions to understanding Christian martyrdom and its interreligious implications. Affording an occasion for comparative theology, specifically on the notion of "witnessing truth", this article turns toward the work of liberation theologian Jon Sobrino on the key role of Christian martyrs, and the theology of signs as found in Ibn 'Arabī's Fusūs al-Hikam, specifically his chapter on Shuayb. While former addresses the ways that Christian martyrs manifest an example like the life and death of Jesus, the latter compliments the heartfelt, affective response that the memory of Frans van der Lugt seems to register with his Syrian audience. On this comparative theological basis, this exercise returns to the performance as itself as a foundation for a concluding reflection that aims to stimulate a case discussion between Muslims and Christians. As such, overall, this article seeks to reconstruct a key moment in that performance as potentially "salutary", "anticipatory", and "communal" in a way outlined in dialogue with Peter Brook. Meanwhile, for outsiders, this narrative approach may offer lessons for a virtue response in keys of solidarity, hospitality, and mercy.

Funding: This research received no external funding.

Conflicts of Interest: The author declares no conflict of interests.

\section{References}

Abramamov, Binyamin. 2015. Ibn al-'Arabī's Fusus al-hikam: An Annotated Translation of "The Bezels of Wisdom". New York: Routledge.

Allen, John, Jr. 2014. Global War on Christianity Is Violent and Real. Crux, April 12. Available online: https: //cruxnow.com/church/2014/04/12/global-war-on-christianity-is-violent-and-real/ (accessed on 4 April 2016).

Aristotle. 2012. Aristotle Poetics: Editio of the Greek Text with Historical Introductions and Philological Commentaries. Edited by Leonardo Tarán and Dimitri Gutas. Leiden: Brill.

Asad, Talal. 1993. Genealogies of Religion: Discipline and Reasons of Power in Christianity and Islam. Baltimore: Johns Hopkins University Press.

Asad, Talal. 2003. Formations of the Secular: Christianity, Islam, Modernity. Stanford: Stanford University Press.

Asad, Talal. 2009. The Idea of an Anthropology of Islam. Qui Parle 17: 1-30. [CrossRef]

Austin, R. W. J. 1980. The Bezels of Wisdom. New York: Paulist Press.

Baird, Marie L. 2005. Witness as a Relation to Alterity: Rahner, Levinas, Derrida. In Encountering Transcendence: Contributions to a Theology of Christian. Edited by Lieven Boeve, Hans Geybels and Stijn Van den Bossche. Leuven: Peeters.

Barghouti, Mourid. 2000. I Saw Ramallah. Translated by Ahdaf Soueif. New York: Anchor Books.

Bayer, Mark. 2007. The Martyrs of Love and the Emergence of the Arab Cultural Consumer. Critical Survey 19: 6-26. [CrossRef]

Begheyn, Paul. 2015. Frans van der Lugt S.J. 1938-2014: Bruggenbouwer en martelaar in Syrië. Nijmegen: Valkhof Pers. Brook, Peter. 1979. Leaning on the Moment: A Conversation with Peter Brook. Parabola 4: 46-59.

Burrow, Colin. 2013. What Is a Shakespearean Tragedy? In The Cambridge Companion to Shakespearean Tragedy, 2nd ed. Edited by Claire McEachern. Cambridge: Cambridge University Press, pp. 1-22.

Chittick, William. 1984. The Chapter Headings of the Fusūs. Journal of Muhiyiddin ibn 'Arabi Society 2: 1-42.

Cook, Michael. 2007. Martyrdom in Islam. Cambridge: Cambridge University Press.

Cornille, Catherine. 2011. The Role of Witness in Inter-religious Dialogue. Concilium 1: 61-70. 
Cunningham, Lawrence. 2011. Christian Martyrdom: A Theological Perspective. In Witness of the Body: The Past, Present, and Future of Christian Martyrdom. Edited by Michael L. Budde and Karen Scott. Grand Rapids: William B. Eerdmans.

Dagli, Caner. 2004. The Ringstones of Wisdom: Fusūs al-hikam. Chicago: Kazi Publications.

Dawson, Anthony B. 2002. International Shakespeare. In Cambridge Companion to Shakespeare on Stage. Edited by Stanley Wells and Sarah Stanton. Cambridge: Cambridge University Press, pp. 174-92.

Escobar, Arturo. 1995. Encountering Development: The Making and Unmaking of the Third World. Princeton: Princeton University Press.

Escobar, Arturo. 2008. Territories of Difference: Place, Movement, Life, Redes. Durham: Duke University Press. Faggioli, Massimo. 2013. Vatican II and the Church on the Margins. Theological Studies 74: 808-18. [CrossRef]

Geertz, Clifford. 1968. Islam Observed. New Haven: Yale University Press.

Gellner, Ernest. 1981. Muslim Society. Cambridge: Cambridge University Press.

Gilger, Patrick. 2014. What Martyrdom Means: On the Death of a Jesuit Brother. America, May 12. Available online: http://americamagazine.org/what-martyrdom-means (accessed on 9 April 2015).

Goldman, Michael. 1972. Romeo and Juliet: The Meaning of a Theatrical Experience. In Shakespeare and the Energies of Drama. Princeton: Princeton University Press, pp. 33-44.

Heffernan, Thomas J. 2012. The Passion of Perpetua and Felicity. Cambridge: Cambridge University Press.

Homsy, Tony. 2015. A Most Annoying Martyr. Catholic Herald (UK), April 2. Available online: http://www. catholicherald.co.uk/issues/april-3rd-2015/a-most-annoying-martyr (accessed on 15 November 2015).

Hubbard, Ben. 2014. Behind Barbed Wire, Shakespeare Inspires a Cast of Young Syrians. New York Times, March 31. Available online: https:/www.nytimes.com/2014/04/01/world/middleeast/behind-barbed-wire-shakespeareinspires-a-cast-of-young-syrians.html?_r=0 (accessed on 5 August 2019).

Johnson, Todd, and Gina Zurlo. 2014. Christian Martyrdom as Pervasive Phenomenon. Global Society 51: 679-85. [CrossRef]

Kohlberg, Etan. 1997. Shahīd. In Encyclopedia of Islam, 2nd ed. Edited by Peri Bearman, Thierry Bianquis, Charles E. Bosworth, Emeri J. Van Donzel and Wolfhart P. Heinrichs. Leiden: Brill, vol. 9, pp. 203-7.

Kottman, Paul A. 2013. Why Think about Shakespearean Tragedy Today? In The Cambridge Companion to Shakespearean Tragedy, 2nd ed. Edited by Claire McEachern. Cambridge: Cambridge University Press, pp. 240-61.

L'Homme, Cristina. 2016. Syrie-Jordanie: Skype réunit «Roméo et Juliette», moment de grâce.". L'Obs, November 21. Available online: https://www.nouvelobs.com/rue89/rue89-monde/20150330.RUE8483/syrie-jordanieskype-reunit-romeo-et-juliette-moment-de-grace.html (accessed on 6 April 2020).

Leclercq, Jean. 1979. Monks and Love in Twelfth-Century France: Psycho-Historical. Oxford: Oxford University Press. Ling, Martin. 1983. Muhammad: His Life Based on the Earliest Sources. New York: Inner Traditions.

Loosley, Emma. 2008. Christianity and Islam in Syria: Island of Religious Tolerance? In Christian Responses to Islam: Muslim-Christian Relations in the Modern World. Edited by Anthony O'Mahony and Emma Loosley. Manchester: University of Manchester Press, pp. 162-74.

Montjou, de Guyonne. 2006. Interviews with Paolo Dall'Oglio, Mar Moussa: Un monastère, un homme, un desert. Paris: Albin Michel.

Morris, James W. 2005. The Reflective Heart: Discovering Spiritual Intelligence in Ibn 'Arabi's Meccan Illuminations. Louisville: Fons Vitae.

Musurillo, Herbert. 1972. Passio Sanctarum Perpetuae et Felicitatis. In The Acts of the Christian Martyrs. Oxford: Clarendon Press.

Nguyen, Martin. 2019. Modern Muslim Theology: Engaging God and the World with Faith and Imagination. Lanham: Rowman and Littlefield.

Pitchford, Gerard Barton. 2019. Hela L'Wein: Performing Nationalisms, Citizenship, and Belonging in Displaced Syrian Communities. Ph.D. dissertation, University of Texas, Austin, TX, USA.

Pope, Stephen J. 2015. A Step along the Way: Models of Christian Service. Maryknoll: Orbis Books.

Rahner, Karl. 1975. Theological Observations on the Concept of Witness. In Theological Investigations. Translated by David Bourke. New York: Seabury Press, vol. 13.

Rahner, Karl. 1983. Dimensions of Martyrdom: A Plea for the Broadening of a Classical Concept. Concilium 163: 9-11. 
Ralston, Joshua. 2017. Bearing Witness: Reframing Christian-Muslim Encounter in Light of the Refugee Crisis. Theology Today 74: 22-35. [CrossRef]

Rippin, Andrew. 2005. Witness to Faith. In Encyclopaedia of the Qur'ān. Edited by Jane Dammen McAuliffe. Leiden: Brill. [CrossRef]

Schaeffer, Hans. 2018. Introduction. In Mercy: Theories, Concepts, Practices. Edited by Hans Schaeffer, Gerard den Hertog and Stefan Paas. Zurich: Lit, pp. 1-6.

Shakespeare, William. 1990. Romeo and Juliet. New York: A Signet Classic.

Sobrino, Jon. 1993. Jesus the Liberator: A Historical Theological Reading of Jesus of Nazareth. Translated by Paul Burns, and Francis McDonagh. Maryknoll: Orbis Books.

Sobrino, Jon. 2001. Christ the Liberator: A View from the Victims. Translated by Paul Burns. Maryknoll: Orbis Books. Sterling, Greg. 2001. Mors philosophi: The Death of Jesus in Luke. The Harvard Theological Review 94: 383-402.

Stosch, Klaus von. 2012. Comparative Theology as Liberal and Confessional Theology. Religions 3: 983-92. [CrossRef]

Strathmann, H. 1967. Martos. In Theological Dictionary of the New Testament. Edited by Gerhard Kittel. Translated by Geoffrey W. Bromiley. Grand Rapids: W. B. Eerdmans, vol. 4, pp. 474-514.

Tabb, Brian. 2015. Is the Lucan Jesus a 'Martyr'? A Critical Assessment of a Scholarly Consensus. Catholic Biblical Quarterly 77: 280-301.

Talbert, Charles H. 1982. Martyrdom in Luke-Acts and the Lukan Social Ethic. In Political Issues in Luke-Acts. Edited by Richard J. Cassidy and Philip J. Scharper. Maryknoll: Orbis Books, pp. 99-110.

Taneja, Preti. 2015. Sweet Sorrow as Star-Crossed Lovers in Syria and Jordan Connect via Skype. The Guardian, April 14. Available online: https://www.theguardian.com/stage/theatreblog/2015/apr/14/romeo-and-julietstaged-in-amman-and-homs (accessed on 13 November 2015).

Valiente, O. Ernesto. 2014. Renewing the Theology of Martyrdom. Irish Theological Quarterly 79: 112-27. [CrossRef] van der Lugt, Frans. 2012. Lief en leed uit Homs. Streven 79: 592-97.

(C) 2020 by the author. Licensee MDPI, Basel, Switzerland. This article is an open access article distributed under the terms and conditions of the Creative Commons Attribution (CC BY) license (http://creativecommons.org/licenses/by/4.0/). 
Article

\title{
Theodramatic Themes and Showtime in Nassim Soleimanpour's White Rabbit Red Rabbit
}

\author{
Charles A. Gillespie \\ Department of Catholic Studies, Sacred Heart University, Fairfield, CT 06825, USA; gillespiec4@sacredheart.edu
}

Received: 9 July 2020; Accepted: 23 September 2020; Published: 29 September 2020

\begin{abstract}
This essay engages the experimental playwright Nassim Soleimanpour's White Rabbit Red Rabbit alongside the theological dramatic theory of Hans Urs von Balthasar. Every Soleimanpour play can only happen once. Actors receive the script as they begin the show; any given actor must perform Soleimanpour's drama as a cold reading unique in history. I propose "Showtime" to theorize this theatrical temporality, exemplified by White Rabbit Red Rabbit and shared by von Balthasar's theology, on analogy to stage space. This article further examines the play's themes of identity, self-sacrifice, free obedience, and writing about time through a "theodramatic structural analysis" keyed to von Balthasar. Soleimanpour expands Balthasarian theodramatics in unexpected and unintended directions. So too did the performance of White Rabbit Red Rabbit I attended in 2016 that featured Wayne Brady as the actor. This essay concludes with analysis of that performance and how it places this essay's theodramatic structural analysis into contexts of race and the history of anti-Black racism in the United States.
\end{abstract}

Keywords: Balthasar; improvisation; time; death; theatrical hermeneutics

\section{Introduction}

I performed as audience in a strange play one night in 2016, one where the actor held the script and we discovered its meaning together for the first time. White Rabbit Red Rabbit told its story about time, obedience, and death (Soleimanpour 2017). I witnessed what I took to be a religious drama, one where the faithful might feel compelled to kneel in deference to the real presence of God. Others, perhaps, saw a raucous improvised comedy on the edge between a piece of theatrical drama and performance art. I wonder whether Nassim Soleimanpour ever thinks about his play as a work of dramatic Christian theology? Playwright Nassim Soleimanpour both is and is not the actor's voice in White Rabbit Red Rabbit, on analogy to how God the Father both is and is not God the Son. Like all analogies, an appeal to trinitarian theology to explain an experimental play falls short. Soleimanpour's rabbits are not Easter bunnies.

My aim, then, is not to explain but to think about Soleimanpour's play in the company of another sort of dramatic theologian, the Swiss-Catholic Hans Urs von Balthasar and his five-volume Theo-Drama (Balthasar 1988, 1990, 1992, 1994, 1998). White Rabbit Red Rabbit exemplifies what von Balthasar imagines to be drama's contribution to a Christian philosophical theology. This essay attempts a "theodramatic structural analysis" of Soleimanpour's play.

For von Balthasar, theatrical drama aids investigation into the frameworks that undergird theological reasoning according to Christian religious symbols in response to God's self-revelation by participants in that real and ongoing drama. Drama foregrounds freedom, action, and presence, and these are also key theological themes for interpreting God's relationship to humans and the created world. But theatre also displays how philosophical theology might be presented to and shared by a mixed and public audience. If drama promises a structure (in Balthasarian terms, a "form") for seeing theology at play, then White Rabbit Red Rabbit demonstrates the importance of theatrical drama 
for thinking about sacrifice, obedience, and the risks of a dramatic ending already written to be sent forward beyond time. Such themes reflect "dramatic resources for theology" even without the use of overt religious symbols, reportage of religious experience, or revealed knowledge derived from faith. Sacrifice, obedience, and writing about and across time are "theodramatic" categories—deploying von Balthasar's term for theological dramatic theory—-that help clarify the stakes of Soleimanpour's still ongoing theatrical experiment.

But what could possibly be meant by my phrase "dramatic ending already written to be sent forward beyond time"? How does convoluted dramatic temporality unfold theological themes of sacrifice and obedience? For those interested in von Balthasar's theodramatic analogy for Christian theology, Soleimanpour would expand a theologian's theatrical canon to include more contemporary, non-naturalistic, non-European, and non-Christian drama. ${ }^{1}$ Such a reading extends Jennifer Newsome Martin's distillation of von Balthasar's "principle of generosity toward the often ambiguous cultural contribution of the world, as Balthasar sanctions the mediatory or revelatory capacity of cultural products: music, art, drama, prose literature, and poetry, even those not explicitly or exceptionally Christian" (Martin 2015, p. 201). Particularly, White Rabbit Red Rabbit's metatheatrical ruminations on the drama of history dovetail nicely with von Balthasar's own sense of the world's Christian salvation drama (Quash 2005). But this essay intends more than only a Balthasarian reading of an experimental play. Instead, it also looks to Soleimanpour's play as a model for highlighting the latent religious dimensions of theatrical hermeneutics, particularly in regards to temporality and texts and performing communities. $^{2}$

Any given performance of White Rabbit Red Rabbit self-consciously underscores its uniqueness in history. Soleimanpour's script has been played hundreds of times, but each and every performance demands a new actor to discover the drama for the first time alongside the audience. The performance thus underscores a singular, unrepeatable happening in the lives of its players (actor and audience) as well as the performance history of the world. ${ }^{3}$ While the same "eph-hapax" quality might be said theoretically about every theatrical performance, the theatrical conceit of White Rabbit Red Rabbit depends on theatrical drama's formally repeatable historical singularity (Balthasar 1988, p. 21). ${ }^{4}$ In other words, any given actor can only play White Rabbit Red Rabbit's script once, but that script can be and has been reused time and again by new and different actors. After generally tracing some of

1 There is an undeniable Eurocentrism to von Balthasar's dramatic theory as a "product of the Western world ... although originally [the world-stage concept] arises from an awareness of the world which is at least as Asiatic as it is European. Quite apart from the Greeks, countless other peoples have been acquainted with the cultic and mythic drama: Egypt, Babylon, China, Indonesia, and Japan with its Noh plays that survive to this day". (Balthasar 1988, p. 135). But von Balthasar contends that the exclusion of other religions and cultures reflects the finitude of a single reader enmeshed in a particular culture. He puts it explicitly in the "Foreword" to the first volume of the entire trilogy of which Theo-Drama is the middle part: "But the author's education has not allowed for such an expansion, and a superficial presentation of such material would have been dilettantism. May those qualified come to complete the present fragment" (Balthasar 1982, p. 11). The finite human can only interpret God from the standpoint of human finitude, and this includes social location and education as well as choices regarding the sorts of arts and cultures a theologian consumes.

2 Many Christian theologians have identified the productive resonance between theological interpretation and dramatic interpretation. (See, among many, Vanhoozer 2005, 2014; Vander Lugt and Hart 2015) For von Balthasar, "All theology is an interpretation of divine revelation. Thus, in its totality, it can only be hermeneutics" (Balthasar 1990, p. 91).

3 On the uniqueness of historical events in theatre history, see (Balthasar 1988, p. 301).

4 Repeatable historical singularity shows why von Balthasar's believes drama, an event that unfolds in time characterized by free action, must become a preferred mode of Christian theological interpretation. All the more so if there is "a biblical answer to the question" of human existence that might be "intelligible to human beings". The "human dramatic question" of existence receives God's "divine dramatic answer". God's definitive, unique, and singular historical action in and through the person of Jesus the Christ "is relevant in all ages". Von Balthasar coins the neologism "eph-hapax" from the Greek eph- (as in the "all over" quality to skin in "epidermis") and hapax ("once") to describe this universally applicable "unique answer to all instances of the question" posed by the drama of human existence. "Eph-hapax" alludes to the technical term from literary and biblical criticism: hapax legomenon, a word that appears only once in a given text. Ironically and poetically, von Balthasar's term "eph-hapax" appears three times in the five volumes of Theo-Drama but only in the single cited paragraph on (Balthasar 1988, p. 21) ("ephhapax" in the German, cf. Balthasar 1973, pp. 20-1). The paragraph clearly proceeds with the Bible in mind, but the three-fold singularity of "eph-hapax" in the text and its object of reference (i.e., the action of God in the Christ "most acute" when "Good Friday turns into Easter") perhaps also means to invoke von Balthasar's trinitarian Christology. 
the play's themes "in abstract", I will turn to the particular performance of the play I witnessed as a participant-observer and its productive frictions between history, text, performance, and interpreting community. White Rabbit Red Rabbit calls attention to theatrical drama's situatedness within and in response to a much wider story, including stories that actors, audiences, playwrights, and producers may never have intended to be told.

It is best to include, however, a warning. Scholarship about contemporary theatrical drama risks spoiling the plot. For some, the "spoiler" is a kind of ruin to the fun of discovery that prematurely releases dramatic tension; for others, "spoilers" empower critique. ${ }^{5}$ In the case of White Rabbit Red Rabbit, such "spoilers" necessarily transform the object of consideration for the uninitiated. To already know the contents of the play's next page changes the play's theatrical possibilities and player's theatrical choices. Indeed, Soleimanpour prohibits foreknowledge about that which is unrelentingly destined by the printed script: "Give the actor the instructions below 48 hours before their performance. DO NOT give them a copy of the play. Ask them not to see the play, nor to learn anything about it before" (Soleimanpour 2017). ${ }^{6}$ Such rules do not govern the audience; it is certainly possible to see this play again and again, night after night. Soleimanpour explicitly directs this prohibition to the performer alone. But all first-time witnesses to White Rabbit Red Rabbit play along in their own role. In a qualified sense, everyone who does not already know the play's script shares the actor's experience of time. The end has already been written, printed, given, and held by the actor, but its contents are not yet fully revealed or realized. I contend that this structural dynamic makes the play evocative of Abrahamic religious temporality. The entire book of history has been written and remains known to God in God's providence, but the world's story unfolds with human freedom and under the author's divine command against divination and soothsaying. Obedience to tradition, too, becomes a motif in White Rabbit Red Rabbit. I dutifully commend my reader to follow Soleimanpour's instructions and consider watching or reading the play for the first time prior to continuing this essay to get a sense of the play without the "spoilers" necessary for my writing. Already, theatrical obedience and timing become complicated themes.

\section{Words, Presence, and Soleimanpour's Theatrical Style}

Theatrical words can transcend historical boundedness and political boundaries. ${ }^{7}$ Soleimanpour plays with language as a recurring theme in order to transfigure the relations of history and relationships across space and time. The play speaks from pasts, presents, and futures as an autonomous text. Its script renders the actor into a prophet of a non-existent past, and its plot meditates on the very problem of con-scripting an actor to follow the play down this rabbit hole. To perform with a script is, for Soleimanpour, to be obedient to that script's mission. The actor issues the commands of the playwright: "I actually made someone make you do something. [ . . ] What are your limits of OBEDIENCE?" (Soleimanpour 2017, p. 25). Theatre, therefore, demonstrates an analogous obedience to the one expected in response to the call of God. Obedience to God differs from obedience to a

5 Certain theatrical styles, such as Bertolt Brecht's Epic Theater, intentionally give away the plot so as to encourage critical and distanced reflection on its political and ethical meanings.

6 The first words of the printed script are "Instructions to the Producer/Presenter". Some pages of the print version, such as the one referenced here, are not numbered. Soleimanpour includes words in all capitals as a way to indicate something important for the actor to emphasize. All of the capitalization, boldface, and underlining in my quotations from Soleimanpour's script match the original.

7 Soleimanpour is not alone amongst twenty-first-century playwrights who use theatre to cross religious, colonial, and militarized boundaries between the middle east and the north Atlantic, but Soleimanpour's experimental form sets his work apart. For example, Tony Kushner's Homebody/Kabul (Kushner 2004) approaches quite similar ideas about border-transgressing poetics thematically. Similarly, too, the multiple published versions of Kushner's play carry their own sense of an "unfinished" project. Kushner's Homebody/Kabul, however, deploys many of the expected conventions of a Broadway or West End production (e.g., memorization, naturalistic costuming and acting, scenes, a curtain call) missing from White Rabbit Red Rabbit. 
playwright's text (rarely is God so straightforward), yet a text speaks action into being without its own voice.

Obedience to the text requires the actor's free choice to be obedient. To borrow Paul Ricoeur's phrase, the script is a "mute text" until the actor communicates on its behalf. "This communication needs an INTERMEDIATE ... the person who is called THE ACTOR" (Soleimanpour 2017, p. 24). Is the "I" spoken by a character co-identical with the ego of the actor or the playwright? Or are we already playing roles dictated to us by innumerable cultural scripts? Soleimanpour displays such roles in the playful animal pageants and rabbit parables of the script (Soleimanpour 2017, pp. 16-17, 38ff). Clear distinctions between what marks obedience to a "felt presence" in religious experience (a "call") or obedience to unspoken social rules can be difficult to draw (Dox 2016). ${ }^{9}$ White Rabbit Red Rabbit posits a playwright responsible for the text now printed on the physical script. The playwright's body remains distinct and distant from the historical event of performance, but he is nonetheless given a present voice by the actor. Audiences hear Soleimanpour's "I" in the actor's voice. Accounts of easy co-identification between actor and writer further rupture in Soleimanpour's later work, Nassim, a heartfelt piece about language and home, where Soleimanpour plays himself alongside another unknowing and unknown actor.

I want to linger for a moment with the comparison between White Rabbit Red Rabbit and Nassim to delineate some of Soleimanpour's theatrical techniques and style. Both plays are exercises in what Aida Rocci calls Soleimanpour's "manila envelope theatre" (Rocci 2017). Any given performance features an actor who does not know the play's script in advance. That is, both pieces feature a "COLD READING" (Soleimanpour 2017, p. 3) from printed scripts by actors with the help some of our era's ubiquitous telecommunications technology and some plot-consequential props. Nassim even includes live projections and photography as a part of the fun. As a genre, Soleimanpour's "manila envelope" dramas foreground their own materiality. Though the plot is metatheatrical and seems to be mostly an actor talking about actors talking, a Soleimanpour script cannot be dematerialized into memory or smoothed into the veneer of spontaneity in rehearsals. ${ }^{10}$ Performances will be rife with mistakes and improvisations as easily understood to be innovations as they might be considered "glitches" in the theatrical ritual (Grimes 2014, p. 73). ${ }^{11}$ Both Nassim and White Rabbit Red Rabbit invite the audience to participate, both on stage and off. Both Nassim and White Rabbit Red Rabbit collapse distance and estrangement by means of a shared and textually mediated experience. Both Nassim and White Rabbit Red Rabbit prompt us to consider Soleimanpour's biography as revelatory or, perhaps, at least interesting enough to merit a night's entertainment.

The figure of the playwright is present for both plays, but in very different modes. The instructions to the producer of White Rabbit Red Rabbit requests (quite politely) that "it might be nice" if an "empty

8 "The text is mute. An asymmetric relation obtains between text and reader, in which only one of the partners speaks for the two. The text is like a musical score and the reader like the orchestra conductor who obeys the instructions of the notation" (Ricoeur 1976, p. 75). Here, Ricoeur is not being esoteric. Texts are mute because they lack the mouths to speak on their own behalf. Soleimanpour's theatrical script operates like Ricoeur's reference to a musical score: in order to speak the text/script/score must be played.

9 Donalee Dox's Reckoning with the Spirit in the Paradigm of Performance opens new ways to consider the spiritual knowledge imparted by "what cannot be seen in vernacular spiritual practices but is (for practitioners) nonetheless present" (Dox 2016, p. 148). Empiricist methodologies that require the confirmation of presence only through material and measurable proof create difficulties for performance studies interpretations. Dox calls performance the "permeable boundary between people's sense of an inner, spiritual life and the bodies acting in the materiality of culture" (Dox 2016, p. 60). For Dox, the materialist norms of the "performance paradigm" dismiss or explain away spiritual knowledges prior to serious investigation on practitioner's terms.

10 Soleimanpour's experimental approach-“for ME, this is not so much a PLAY, as an EXPERIMENT" (Soleimanpour 2017, p. 3)—exemplifies Larry D. Bouchard's "three overlapping sorts of metatheatre" (Bouchard 2020, p. 4). Both Soleimanpour's style and the White Rabbit Red Rabbit script foreground the theatricality of each performance (MT-1); the titular rabbit parable with its audience participants and animal pantomimes constitute a show within a show (MT-2); and the play's metaphors about obedience, suicide, and life (Soleimanpour 2017, p. 46ff) present the entire event as MT-3.

11 For Grimes, "ritual glitches" are noticeable and unintended disruptions to ritual action, like a "badly timed flyover of military helicopters" that can stop a public reading (Grimes 2014, p. 110). A ritual glitch calls attention to ritual as human activity capable of "failure" and open to criticism. 
seat in the front row" be reserved for the playwright. ${ }^{12}$ The script calls repeated attention to the mobile "self" of the narrating actor and the script's writer. Do actors play Soleimanpour or themselves? It is not an Iranian dissident in 2010 who commands the scene but printed papers that construct a world and invite action. "Sometimes I get scared writing this play. I feel I'm designing a BIG GUN which will shoot somebody one day. Maybe even myself" (Soleimanpour 2017, p. 35). These pages and the risks inherent in their interpretation must be given over to someone else to read. Words and stories connect across real time and space. White Rabbit Red Rabbit instructs its audience members to send Soleimanpour an e-mail during the course of the play. In the print version, "nassim.sn@gmail.com" still appears prominently in and around the text. Nassim, by contrast, calls for Soleimanpour himself to be there, a character in his autobiographical play. Both pieces therefore confront and build theatrical identities through materiality, confirming how human characters and non-human props "play" on a shared continuum in performance. Nassim even concludes with a totem of its performance history: a book filled with instant-print photographs taken at every performance. (Archaeologists who uncover this artifact can locate the performance I attended in Dublin by looking for an image with an airline blindfold, my "gift" to Nassim during the play.) ${ }^{13}$ History and meaning are co-constructed between audience and actor. Where White Rabbit Red Rabbit concludes in silence and e-mail, Nassim concludes with a phone call in Farsi. In Soleimanpour's theatrical drama, communication becomes embodied and technologically mediated. Words, even if misunderstood, connect people through the things and experiences we share.

\section{Porous Boundaries of Stage Space and Showtime}

Soleimanpour's words (mediated through bodily movement, breath, speech, and material technologies) create the conditions of theatrical presence both spatially and temporally. The actor in Soleimanpour's play holds the pages of the script as a prop that is part of the show. The script has its own agency as a player in the drama. Scripts can be metaphors as well as physical objects. Soleimanpour's drama revels in this ambiguity. By asking audiences to give unplanned gifts (Nassim) or to use their smartphone to communicate in medias spectaculum (White Rabbit Red Rabbit), Soleimanpour points beyond the symbolic and literal perimeters of the stage space-so objects in the pocket of an audience member might become props, too. The script's words trigger present embodied actions that erase the boundary between active players and passive watchers. Soleimanpour's plays are full of invitations for the audience to become what Augusto Boal calls "spect-actors", simultaneous observers and participants in the theatrical event (Boal 1985). ${ }^{14}$ During White Rabbit Red Rabbit every member of the audience assigns themselves a number and speaks it aloud; some numbers are called to play along with the script (Soleimanpour 2017, p. 2). The script therefore assigns roles to the members of the audience (one, two, three, and so on); sometimes and for some people, the script transforms those roles into missions. Number 5 always receives the crucial instructions to set the plot in motion: "I want you to choose a glass of water, take the vial and stir its contents into the chosen glass with the spoon. Then put the cap back on the vial. Go ahead. AND BE CAREFUL. DON'T SPILL ANYTHING" (Soleimanpour 2017, p. 5). These rules are written into the script as part of its dialogue. At other points, the script invites unspecified volunteers to take on a scripted role. ${ }^{15}$ During the play's off-Broadway run in 2016, Nathan Lane joked about his distaste for audience participation, for him a theatrical taboo that "falls somewhere between incest and folk dancing" (Gioia 2016). Certainly, all conscious audiences

12 Soleimanpour has since witnessed and participated in performances of White Rabbit Red Rabbit. For a description, see (Youngs 2013).

13 I saw Nassim at the Project Arts Center as a part of the Dublin Theatre Festival on 6 October 2018.

14 Von Balthasar's theory of theatre makes the same point, though without invoking Boal's sense of political action or his technical term: in Theo-Drama "the boundary between the actor or agent and the 'auditorium' is removed, and man is a spectator only insofar as he is a player" (Balthasar 1988, p. 18).

15 An unspecified volunteer becomes especially important at the play's conclusion by playing the role of the "White Rabbit" (Soleimanpour 2017, p. 57ff). 
participate in a theatrical performance; Soleimanpour even warns how "it is YOU, spectators, who ARE there. YOU are there. YOU are participating" (Soleimanpour 2017, p. 56). ${ }^{16}$ Soleimanpour's script commands a violation of the spatial boundary between actor and audience, the 'sacred' distance that sets apart stage and seats in the house. The absent Soleimanpour, through the voice of the actor, calls these number-characters up to the stage to play along. The opening counting ritual concludes by musing on the question "Did you count me?" (Soleimanpour 2017, p. 3). Theatrical presence and participation need not be reduced to spatial proximity.

But Soliemanpour's drama also blurs the temporal boundaries between actor, audience, and playwright in its conscious construction and subversion of what I call "Showtime". Theatre always calls time to mind. ${ }^{17}$ It takes time to perform a story. ${ }^{18}$ Rebecca Schneider explains, "Time is the stuffing of the stage-it's what actors, directors, and designers manipulate together" (Schneider 2014, p. 7). Showtime is that time set apart from other times by a theatrical event and during which a theatrical event occurs. ${ }^{19}$ Showtime identifies the temporality of performance, the temporal dimension of the stage's space shared by performers and audience. One does not require a proscenium arch to make a stage, but the activity of performance, what Peter Brook calls the "act of theatre", brings a stage into being for some witness (Brook [1968 ] 2019). This is the difference between the scaffold that makes a platform in the front of any potentially empty auditorium and the performance that renders that platform into a stage for the show. In Shakespeare's famous speech, Jacques announces "All the world's a stage" thanks to its mere "players" with "entrances and exits" (Shakespeare 2006a, II.7). The boundaries of the world-stage, then, are not galactic wings or an oceanic apron but human parcels of passing time. Showtime is that which a showstopper disrupts but does not negate. Here, I distinguish "Show time" from the description of a given performance's "run time": the show's duration as a length measurable by a clock. Speeches after a curtain call do not add to a play's run time, but they are an aspect of this performance's Showtime. Breaks for applause or laughter or lament constitute meaningful moments of a theatrical event. A subway car is not an architectural stage, but, in New York City, the (often unwelcome) announcement of "Showtime!" could transform mass transit into an acrobatic arena in the time between stops. Yet a play can twist time into knots, imagining morning sun after sunset or plunging a midday performance into midnight darkness. Hamlet reminds us how theatrical "time is out of joint" (Shakespeare 2006b, I.5). Showtime holds the strangely mutable and subjective experience of time's passing during performances. The same duration of time might carry a thick slowness for a dull play or a surprising lightness and speed during an exciting one. Showtime, therefore, refers at once to the "time of the play" (as in the drama's temporal settings and its performance histories) as well as the "play's time" (as in the theatrical event that occurs in time and with time). Just as a performance needs its stage space, a performance happens during Showtime.

Stages are places set apart within a wider geography, so too Showtime sits apart from other times within wider histories. ${ }^{20}$ Every performance of White Rabbit Red Rabbit remains singular thanks

16 Near the end of the play, Soleimanpour includes "PASSIVE" witnessing as a mode of participation for "my spectators", those numbered and present (Soleimanpour 2017, p. 56ff).

17 Many scholars have taken up the question of theatrical temporality. Time, after all, is a fundamental analytic category for drama and appears in Aristotle's Poetics as one of its "three unities of time, place and action" (cf. Wiles 2014, p. 55). Aristotlean time is not the only option. Maurya Wickstrom's Firey Temporalities in Theatre and Performance: The Initiation of History reviews how theatre's time can interrupt passive, "processional histories". Wickstrom tracks plays and performances like Soleimanpour's where conventional distinctions between past and present shift into the potentially emancipatory relationship between what has already been and what Walter Benjamin calls "a now" (Wickstrom 2018).

18 Theatre foregrounds the connection between Times and Narrative enumerated across (Ricoeur 1984). There can be no hard distinctions between reading theatrical drama and performing it. In many ways, "reading time" and time spent recalling a production expand to complicate the boundaries of Showtime. Encounters with theatrical drama-reading and seeing and remembering-always occur during some passage of time.

19 Anne Ubersfeld's semiotic approach to theatre and time begins its analysis by identifying how "theatrical time" can be understood as the relationship between the "two distinct temporalities" of theatrical phenomena: "the time it takes for a performance to be completed ... and the time pertaining to the represented action" (Ubersfeld 1999, p. 126, emphasis original).

20 Performance, like play and ritual, sets itself apart in place and time from other phenomena. My analysis of performance incorporates the philosophy of play at its root. Consider how English language words for theatre show this essential link 
to the prohibition on foreknowledge and its always different actor, but the script also calls out the singularity of its temporal moment in history. ${ }^{21}$ At one point, the actor demands that Number 6 announce the day of the week, the date, and the year of this performance (Soleimanpour 2017, p. 19). Soleimanpour uses this information to differentiate, but not sever, the time of the playwright from Showtime. Immediately after Number 6 provides the date, the actor says "The day I'm writing THIS part of the play is 25 April 2010. So you see how even MY TIME differs from yours" (Soleimanpour 2017, p. 20). The time of composition has been caught up into Showtime. Usually, Showtime would be a time of multiple citations. Showtime bridges the "gap" between the "liveness" of theatre and a given play's rehearsal and performance histories (Schneider 2014, pp. 68-69). But because every performance of White Rabbit Red Rabbit calls for a unique cast, the actor possesses no rehearsal record to recall and re-present. Indeed, this extemporaneous performance appears like a rehearsal with communal improvisation in the presence of the playwright's script. Showtime marks the time of communal endeavor. Soleimanpour foregrounds the "now" of Showtime in self-conscious awareness of the ongoing present moment. Showtime does not resolve Zeno's paradox, but it demarcates the finite experiences of beginning and ending. ${ }^{22}$

White Rabbit Red Rabbit makes an interesting test case for Showtime precisely because it is not a piece of durational theatre that indexes the time of its own performance or responds to a specific moment of time. ${ }^{23}$ Audiences might perceive some beginning and perceive some end as the fluid limits of Showtime. In this play, temporal limits echo in the spatial limits of the stage or the limited pages of the printed script. The audience sees a sign of Showtime's end as it approaches: the script's pages do not go on forever. Conventional theatrical drama marks the threshold of Showtime with the rituals of a curtain call: bows and applause. But, like so many theatrical experiments that unfold into the night—consider Richard Schechner and the Performance Group's Dionysus in 69 and its parade into the streets-White Rabbit Red Rabbit frustrates a clear moment of transition from Showtime to after in its conclusion (Performance Group 1970).

\section{Dead Ends: “You May Not Touch Him. You May Not Check His Health"24}

Showtime differentiates the porous temporal and spatial boundary between the event and the play's afterlife in conversation, worry, delight, confusion, and memory. The play concludes with an invitation for reflection in the presence of death's possibility. "Dead or alive, [the actor] will want to lie down on the stage for a time and think. About everything" (Soleimanpour 2017, p. 60). So, too, will the many spect-actors who depart from the hall. The play stops with the death of the actor who gives life to words. Showtime ends, somewhere, between the seats and the shuffle to the exit. The end of Showtime symbolizes mystery or a transcendent sacred in thin analogy to the moment of death.

between play and performance. The phrase "a theatrical performance performed in a theater by theatrical performers" could just as easily be written as "a play played in a playhouse by players". "Play is distinct from 'ordinary' life both as to locality by and duration" (Huizinga [1944 ] 1950, p. 9). For Huizinga, playing makes and underlies representation in ritual and dramatic performance, culture, poetry, and art. Huizinga's theory informs Hans-Georg Gadamer's notion of play as a clue to the ontology of the work of art. (See Gadamer 1989, p. 101ff.) For a more recent application of play to the analysis of religion and theatre, see (Mason 2019). For Mason, "Playing creates being, in any way that the word being makes sense" (Mason 2019, p. 118).

21 The play highlights how time may be marked through differing religio-cultural calendars. Soleimanpour provides his birthdate both according to the Islamic-Solar Hijri calendar prominent in Iran ("Azar 19th, 1360") and Christian-Gregorian calendar used in most places where the play would be performed ("10 December 1981") (Soleimanpour 2017, p. 19).

22 Questions remain as to when one's experience of a play begins: when does the show start for me? When I see advertisements and this production first appears to my consciousness? When I buy my tickets and begin to anticipate the event as a kind of business transaction? Perhaps when I physically enter the venue or pose for a photo under the marquee? Or is it when I sit down and silence my electronic devices so to limit my distractions from the outside world and enter into the time of the play? These questions ask nothing about the preparation of the actors! Instead, Showtime refers to the overlapping time of performance shared between actor and audience.

23 For more on durational theatre in the context of theatrical temporalities, see the discussion of Karlheinz Stockhausen's Mittwoch aus Licht in (Wiles 2014, pp. 61-67).

24 (Soleimanpour 2017, p. 60). 
Soleimanpour makes this analogy explicit: the sending at the finale of White Rabbit Red Rabbit concludes this performance's unique Showtime with the instruction for a member of the audience to take the script as gift for future use (Soleimanpour 2017, p. 62). The White Rabbit, played by a member of the audience and now the one leading collective obedience to the script, establishes the last law: "After hearing 'the end,' everyone must leave the theatre" (Soleimanpour 2017, p. 60). There will be no time to confirm the impermanence of theatrical suicide. There will be no curtain call ritual to clap distance between Showtime and after, to give away numbers and responsibility. The symbolism of the possibly dying body on stage aligns with the departure of the audience, both "exits" in silence and doubt.

The Showtime of Soleimanpour's play stops in death. One line of interpretation, interested in the ethics of causality, follows the play's focus on the question of the "gun" mechanism: who is responsible for the actor's "death"? Soleimanpour? The actor? The producers? The audience volunteers? The audience witnesses? Industrial capitalism $?^{25}$ The script calls forth the conditions for a suicide or homicide or accidental interpersonal violence as entertainment. Soleimanpour highlights how the conditions of this theatrical experiment and its scripts-preset props, authoritative instructions, social expectations-are no different from ordinary social life. Given circumstances might always be turned over to some risk of life and death. Such is the meaning of the titular white and red rabbit parable: ordinary obedience quickly escalates to extraordinary cruelty.

But another line of interpretation goes down its own rabbit hole resonating with what Kevin Hart calls the "dark gaze" onto the sacred in Maurice Blanchot's mystical atheism. Like Soleimanpour, Blanchot enacts a "displaced mysticism of writing [where] to write is to transform the instant into an imaginary space, to pass from a time in which death could occur to an endless interval of dying" (Hart 2004, p. 10). ${ }^{26}$ White Rabbit Red Rabbit opens towards the sacred in its attention to death's uncompromising mystery. "What MATTERS is NOTKNOWING" (Soleimanpour 2017, p. 33). ${ }^{27}$ The play ritualizes the mystical encounter with uncertainty and its "POSSIBILITY" (Soleimanpour 2017, pp. 32, 50). Drama proceeds in the subjunctive. The risk of death is both playful and existential; the performance of suicide requires both a theatrical choice and unrehearsed trust (perhaps even quasi-religious faith) in the harmlessness of the show's props. "This is a theatre, so its VERY probably FAKE ... right?" (Soleimanpour 2017, p. 30). The line's dramatic irony relies on an established theatrical tradition and faith in theatrical conventions and their moral code. But, like other avant-garde performance experiments, the play elides physical appearance with emotional reality. ${ }^{28}$ The prop poison might well be placebo, but drinking the potion nonetheless risks a credible threat of suicide. The theatrical choice to drink in obedience to the script could bring about all too real consequences. Who knows?

This call for ritual action in the presence of mystery supports my claim to identify the play's structure as "religious" in a qualified and generalized sense. Rather than representation, David V. Mason locates the poetic and playful making of performativity_ "poesis, not mimesis"—as theatre and

25 "I take full responsibility for creating the machine. But I give YOU the responsibility for using it. After all, no one puts the inventor of the gun on trial" (Soleimanpour 2017, p. 55).

26 Hart further demonstrates that "Blanchot's thought of the neutral Outside contests the philosophy of neuter" tracks with how Hans Urs von Balthasar and other mid-century Catholic thinkers dismantled the reigning theological duplex ordo where 'pure nature apart from grace' proposes some "neutral, indeterminate being that is prior to the distinction between infinite and finite being, between God and creation" (10). Blanchot unequivocally rejects Christian revelation, but joins von Balthasar in resisting any urge to domesticate mystery. (See Hart 2004, pp. 48-49.)

27 Claire Marie Chambers offers the term "performance apophatics" to "signify the performative operation that traffics through the denial of denial, which can be felt in the restless dynamic of the unknowable that structures performance itself" (Chambers 2017, p. 10). Soleimanpour's emphatic "NOT KNOWING" calls for "critical unknowing" where "By cultivating learned ignorance, we might unself ourselves at the same time that we might unworld the world" (Chambers 2017, p. 261). Both performance apophatics and theatricality "insist that what is 'real' is not only the real, or that everything that is important or true is 'real'” (Chambers 2017, p. 259, emphasis original).

28 Soleimanpour's play opens ethical questions about integrity like those treated by (Bouchard 2011). Consider, for example, the moment in Dionysus in 69 where "the performance would pause until the actor playing Pentheus actually felt abused by the taunts of other cast members" (Bouchard 2011, p. 224). For a review of the religious underpinnings to American avant-garde theatre and connections to Gertrude Stein's influential views of theatrical time, see (Tanner-Kennedy 2020). 
religion's common root (Mason 2019, p. 156). ${ }^{29}$ A performance of White Rabbit Red Rabbit may very well appear structurally indistinguishable from other "religious" rituals where a sacred text (be it the Bible, Vedas, Qur'an, Book of Common Prayer, or L. Ron Hubbard's Dianetics) prompts ritual obedience. Here is even time for a monetary collection (Soleimanpour 2017, p. 9). The text features two invocations of "god" (Soleimanpour 2017, pp. 13, 24) and one reference to the writer's face while writing, "straight as the devil's" (Soleimanpour 2017, p. 29).

I intend to put Soleimanpour in conversation with a Christian framework, and there is one phrase that might be interpreted as a moment of recognizable revelation: "the [red] rabbit's ears have been EXPOSED. Oh my god!" (Soleimanpour 2017, p. 13). A theodramatic reading perhaps hears echoes of the Centurion who notices the Son of God exposed by crucifixion and earthquake (cf. Matt. 27:54) or "Doubting" Thomas' exclamation at the resurrected Christ's exposed wounds (cf. John 20:28). Further, the text invokes God's blessing_-"MAY GOD SAVE YOU!" (Soleimanpour 2017, p. 24) on the volunteer notetaker who, by freely volunteering, now "is a red rabbit" (Soleimanpour 2017, p. 25). But Soleimanpour's most consequential use of something like Christian religious language happens only in the actor's speech just before handing the script to an audience volunteer and enacting their own theatrical-ritual death (Soleimanpour 2017, p. 55ff). The speech is the confession and pre-emptive absolution of the playwright, "Nassim Soleimanpour" whose full name appears twice (Soleimanpour 2017, pp. 55-56). The word "sin" appears twice as well to describe Soleimanpour's own guilty complicity in the actor's death (Soleimanpour 2017, p. 56). Soleimanpour's writing creates the conditions for the possibility of the actor's death, but it is present action in obedience to his words that might kill. An indictment of the audience interlaces with Soleimanpour's confession. He further argues how any "PASSIVE viewer of this suicide" will be "more of a sinner than me" (Soleimanpour 2017, p. 56). So who is guilty? The confession turns the question of identity back on the writer, whose voice we hear in and through the actor.

Soleimanpour sounds similar to Blanchot by the end of the confession. The question of guilt and sin between author and actor asks about theatrical writing and about revelatory knowing. "In conclusion" the speech shifts into meta-reflection on the affective experience of writing as self-alienation.

I feel what I'm writing is not my writing [ ... ] some OTHER 'ME', lives INSIDE me, and THAT 'me" talks on my behalf-almost as someone to whom I have lent my body. Or maybe I'm reading from someone else's writing, or someone else, some OTHER ME, is loudly speaking ME ... for YOU.

(Soleimanpour 2017, p. 56)

Here, Soleimanpour inverts what Blanchot calls "the Outside" and erasure of ego approached through writing; instead, some "OTHER" writer emerges from "INSIDE" like inspiration. ${ }^{30}$ But where Blanchot's emphasizes the spatial and temporal, the metaphors for writing Soleimanpour's in play are doubly theatrical. ${ }^{31}$ Words come into being only through the "loan" of a body. The author loans a body to write; the actor loans a body to read. Soleimanpour's writing these words requires the same sort of kenotic self-surrender as the actor who speaks them. The moment can be depersonalized: the invisible author makes demands of the visible actor. The experience of writing White Rabbit Red Rabbit matches

29 See also the discussion of ways to pursue a correlation between religion and theatre in (Mason 2019, p. 1ff). In another context, Mason explains "The manner in which the theatrical avant-garde necessarily resembles religious doing comes from the way that performance sharpens this paradox [glossing what he earlier calls 'yearning for presence that proves never possible'] of being in the world" (Mason 2019, p. 59).

30 "If to write is to surrender to the interminable, the writer who consents to sustain writing's essence loses the power to say 'I.' And so he loses the power to make others say ' $\mathrm{I}^{\prime \prime}$ ' in (Blanchot 1982, p. 27). "This is to say: one writes only if one reaches that instant which nevertheless one can only approach in the space opened by the movement of writing. To write, one has to write already. In this contradiction are situated the essence of writing, the snag in the experience, and inspiration's leap" (Blanchot 1982, p. 176).

31 Hart explains how "interval" and "space" both may plausibly translate Blanchot's espace (Hart 2004, p. 8). I add that both terms also carry theatrical resonance, e.g., "intermission" can also be called an "interval". 
its theatrical reading. The conclusion of the quasi-religious confession sees the identity of the invisible author ("ME") given over in the performance of the actor for the audience ("for YOU"). Soleimanpour seems to agree with Blanchot; "Perhaps it is sin" (Blanchot 1982, p. 175). The author and actor align: the written-loaned body offers itself as indifferent and obedient, gift and sacrifice. Both author and actor can now share "MY sin": "the secret of the red rabbit" (Soleimanpour 2017, p. 56). The actor is the author's "dear red rabbit" (Soleimanpour 2017, p. 57) sent to perform death as a revelation.

\section{Seeing the Form}

Revelation anchors von Balthasar's theology. For von Balthasar, humans interpret the God who has revealed Godself dynamically through loving action in history. Theo-Drama occupies the middle panel of von Balthasar's great theological triptych. Each part, further divided into multiple volumes, correlates reflection on God's self-revelation according to philosophical transcendentals of being-Beauty in The Glory of the Lord, Goodness in Theo-Drama, and Truth in Theo-Logic. Each part develops an accompanying theological method-aesthetics, dramatics, and logic, respectively, for Beauty, Goodness, and Truth. The unity of the single project across its many disparate parts expresses the philosophical transcendental of Oneness.

Von Balthasar's writing operates according to what Anne M. Carpenter identifies as a theo-poetic style: "what he means and how he means it are central concerns. The 'what' is theological truth, and the 'how' is a perplexing combination of theological and poetic language" (Carpenter 2015, p. 3, emphasis original). Drama speculates on God in the light of Goodness that prompts considerations of God's action and the human position in its midst (drama) rather than God's appearance (aesthetics) or God's utterance (logic) (Balthasar 1988, p. 18). Good actions give freely. Theatre, in its presentation of the drama of human existence, provides analogous structures with which to think theologically: one needs to "play" Christian theology within the givenness of the world of theodramatic play. That is, von Balthasar's theodramatic approach demands the imaginative assent of the interpreter to God's initiative: doing theology is like doing improv. My scene partner (or a script) suggests some "given circumstances" and actors need to respond with actions that fit within that given world. My impersonation of a bunny making a big, steaming bowl of carrot soup will change rapidly when another actor replies "Yes, and we need to hide it from the hungry bears on the roof!" Without any rehearsal or hesitation, I become responsible to hop to it and play interpretive choices that work here and now with what I have been given. ${ }^{32}$ Such acting-often surprising and funny-openly receives and inhabits the world that is given. The improvising actor co-creates the theatrical world by choosing to play along. So too for theodramatics: there can be "no external standpoint" outside the drama of God's action in history (Balthasar 1990, p. 54ff). God's drama "so overarches everything, from the beginning to the end, that there is no standpoint from which we could observe and portray events as if we were uninvolved narrators of an epic. [ . . ] In this play, all the spectators must eventually become fellow actors, whether they wish to or not" (Balthasar 1990, p. 58). Even God's inner life, the Trinity, becomes the wider drama within which created history unfolds: "our play 'plays' in his play" (Balthasar 1988, p. 20). ${ }^{33}$

Much has been written about von Balthasar's influence on contemporary Catholic and Christian theology, but less work has focused on his theological dramatic theory in dialogue with contemporary theatre and performance. ${ }^{34}$ Some Balthasarian resonances with White Rabbit Red Rabbit may be already

32 For Konstantin Stanislavki "the circumstances, which for the dramatist are supposed for us actors are imposed, they are a given. And so we have created the term Given Circumstances" in (Stanislavski 2008, p. 52), emphasis original. On the "yes and" rule in improv, see (Frost and Yarrow 2007, pp. 144, 219). For von Balthasar on Stanislavki and what is given to the actor, see (Balthasar 1988, p. 279); on the "extemporaneous play", see (Balthasar 1988, p. 179).

33 For a challenge to the coherence of von Balthasar's theological style, see (Kilby 2012, pp. 64-65).

34 Certainly, drama remains a keyword for Balthasar studies. The most substantial contribution on his dramatic theory remains the German language collection "Theodrama and Theatricality" (Kapp et al. 2000). For the importance of drama to von Balthasar's philosophy, see (Schindler 2004). Theological dramatic theory gives Todd Walatka room to find greater 
apparent, such as how the singular conceit of every performance of Soleimanpour's play offers a microcosm of the singularity of salvation history and the deadly high-stakes of free action. At the same time, a Balthasarian reading of the Iranian experimental playwright seems an odd, perhaps exploitative, choice. Soleimanpour does not identify as a Catholic, and the history of Iranian theatre includes far more influence from Islam than Catholicism. ${ }^{35}$ As already mentioned, the play presents few overtly religious symbols. But I contend that the play's structure might be usefully interpreted in Balthasarian theodramatic terms. He gives us many theodramatic themes to choose, but I will restrict myself to the following five: "theatre of the world", dramatic roles, freedom, obedience, and sacrificial death.

Theatrum mundi. Perhaps the most obvious connection between Theo-Drama and White Rabbit Red Rabbit regards its use of the image of the "world-stage" or "theatre of the world" image, familiar from medieval drama, Shakespeare, Calderon, and others. The first volume of Theo-Drama samples the development of the theatrum mundi image in an eclectic survey of European dramatic literatures. The stage uniquely presents the predicament of created being: "theatre-expressly seen as 'theatre of the world' - is an image that is substantially more than an image: it is a 'symbol of the world,' a mirror in which existence can directly behold itself" (Balthasar 1988, p. 249). ${ }^{36}$ Theological dramatic theory proposes to interpret the entire history of creation as a performance on the world-stage on which God joins. The world-stage metaphor lends Theo-Drama what I would call a performative ontology: creation exists only insofar as it plays with and in God. For von Balthasar, the world-stage embraces the Christian theological vision of creatio continua (a theme where God continually creates the world, and so is present at every moment in its history). Such is also the temporality of performance foregrounded by White Rabbit Red Rabbit: "From now on we are ALL present" (Soleimanpour 2017, p. 2) when "the actor (me), the audience (you), and writer (me)" (Soleimanpour 2017, p. 1) come into contact. What matters is the event of performance, not the "mute" script; only in performance, during Showtime, can the actor and writer both be "me". The world-stage metaphor emphasizes the givenness and goodness of creation for Christian theology as well as the spectator-theologian's situation within the drama of history. Created time and God's eternity meet in action. Dramatic temporality offers von Balthasar language to name how the Christ enfolds created time into God's very life: God's eternal becoming as an event in what von Balthasar calls "supertime" (Balthasar 1998, p. 32).

Dramatis personae. Theo-Drama concerns itself not only with dramatic stories and images but also with the phenomenon of theatrical performance. As such, von Balthasar also takes keen interest in human roleplaying and the various roles of the theatrical ensemble: author, actor, and director. ${ }^{37}$ I have already mentioned the ways in which any interpretation of God's action emerges from fellow actors on the world-stage. God intervenes in human history by stepping onto the world-stage as its leading player. Jesus quite literally saves the show, and Theo-Drama provides tools to think through the Christ's roles. The actor finds identity in the mission of playing their role on stage; humans find their identity in their mission to be disciples of the Christ. "The closer a man comes to this identity, the more perfectly does he play his part" (Balthasar 1990, p. 14). Where social roles might become closed loops and traps, sending and mission actualizes identity. So too, every "spectating" audience to Soleimanpour's play gets brought up into the event of its performance, in the image the prototypical actor. Roles prepare for missions; Number 5 makes the poison drink, everyone gets sent forth from the hall. To understand "Who am I?" requires freely acting the role that I am sent to play in the world. ${ }^{38}$

compatibility between von Balthasar and liberationist themes about preference for the marginalized and concern for economic justice in (Walatka 2017).

35 (See Floor 2005) In an e-mail interview, Soleimanpour avers, “I think I have stronger roots in Iranian Literature [than Ibsen or Beckett]" (Mapari 2017).

36 The phrase perhaps includes an uncited allusion to Hamlet's mirror held up to nature (Shakespeare 2006b, III.2) as well as the quoted reference to the title of Eugen Fink's Spiel als Weltsymbol (Fink [1960 ] 2016).

37 (Cf. Balthasar 1988, p. 481ff) on everyday roleplaying founds in dramaturgical psychology and sociology; von Balthasar begins this section by quoting (Goffman 1959).

38 This question organizes the section on the transition from role to mission in (Balthasar 1988, p. 493ff). 
At the same time, von Balthasar finds a trinitarian analogy in the logical procession of the theatrical roles of author, actor, and director. ${ }^{39}$ Chronologically, too, the practice of a separate, off-stage director emerged rather late in theatre history. ${ }^{40}$ But the logical procession of theatrical roles demonstrates by analogy points of Christian doctrine and its speculations on the eternal movement of the Trinity. None of the co-equally divine persons can be "older" than another, but their relationships might be logically ordered. I cannot offer a detailed summary of von Balthasar's trinitarian theology here as it is so central to his theological project; I will restrict my comments to the triad of author, actor, and director as an analogue to God the Father, God the Son, and God the Holy Spirit. ${ }^{41}$ For von Balthasar, understanding the movement of these roles within God's triune life (processions) provides the clue as to how to understand their work on the world-stage (missions). ${ }^{42}$ The invisible Author-Father acts as the first principle of theatrical movement that sends the visible Actor-Son into the world (Balthasar 1988, p. 279). Because God so loves the world, God the Father sends God the Son in a revelatory and free gift pro nobis, "for us". The procession-mission functions like the sending of the word from the author to the actor in Soleimanpour: "loudly speaking ME ... for YOU" (56). ${ }^{43}$ But the Author-Father and Actor-Son share a common will aligned by the Director-Spirit. ${ }^{44}$ The Director-Spirit proceeds from the ultimate unity of the Author-Father and Actor-Son and assures co-identity between the author and the actor in the performance event. Obviously, the analogical triad of author, actor, and director differs significantly from the Trinity of Father, Son, and Holy Spirit in Christian theology. ${ }^{45}$ The former theatrical triad ordinarily implies three persons in three distinct people; the latter theological mystery remains three divine persons who are always already one God. In White Rabbit Red Rabbit, the author, actor, and director unite in the single performance of the play, revealed to and for the audience exclusively in the visible action of the actor "for us". Soleimanpour provides another "dramatic resource" for Christological-Trinitarian theodramatics beyond the stylings of theatrical naturalism.

Freedom. Drama stages conflict including a contest of wills. The dramatic tension at the center of Christian theology consists in the confrontation between divine and human freedom: God's absolute decision to be in faithful, covenant relationship with the world and the potential for a free human refusal of God's good gifts (Balthasar 1990, pp. 252-53, 301-2). ${ }^{46}$ Soleimanpour makes similar space for rejection in his instructions to the actor: if an audience member refuses to play along that role simply changes to another free volunteer, "But it is important to maintain the SAME NUMBER!" (Soleimanpour 2017). Freedom expresses itself through interacting roles. Von Balthasar's dramatic

39 The analysis of authors, actors, and directors appears on (Balthasar 1988, pp. 268-305). Note phrases throughout that resemble trinitarian theology as "This primacy of unity in the author is ontological" (Balthasar 1988, p. 269).

40 See (Balthasar 1988, p. 298n1), where von Balthasar shows his awareness of this chronological procession but chooses to leave it untreated. Similarly, von Balthasar does not theorize other members of the theatre company that stretch beyond the triad: designers, managers, dramaturgs, stagehands.

41 Von Balthasar's trinitarian imagery is always subtler and rarely so blatant as I here imply. Some moments are more explicit, see (Balthasar 1988, pp. 268-69, 280). I have elsewhere argued that one can map his theatrical triad from Theo-Drama first volume directly onto the trinitarian theology that appears in volume three and five. (See Gillespie 2019.)

42 The principle that the procession gives a clue to mission is Thomistic, and it allows von Balthasar to further analyze the coincidence of person and mission in Jesus the Christ. (See Scola 1995, p. 58.)

43 See also the way Soleimanpour muses about the "private world" of writing "something SIMILAR to a play" (Soleimanpour 2017, p. 3). Drama only becomes a play in its performance by the actor.

44 "Between the dramatic poet and the actor there yawns a gulf that can be bridged only by a third party who will take responsibility for the play's performance, for making it present here and now" (Balthasar 1988, p. 298). The director's role will be to integrate the author and actor: "its whole raison d'être consists in the way it mediates between them" (Balthasar 1988, pp. 298-99).

45 Difference, especially sexual difference, is a key theme in von Balthasar's theology. Trinitarian procession later becomes explicitly gendered in von Balthasar's Theo-Drama. Linn Marie Tonstad finds problems in von Balthasar's active-passive hierarchy that becomes his symbolically sexualized Trinity. For Tonstad, von Balthasar's theology is not only flawed in its construal of the hierarchical relationships between Trinitarian relations, but these missteps concretize in the potential divinization of (worldly) masculinity vis-à-vis the exclusive creatureliness of (worldly) femininity (Tonstad 2016, p. 45).

46 Theological dramatic theory gives space for the realization of a real encounter between divine-infinite and human-finite freedom: "we must assert that unconditional (divine) freedom in no way threatens the existence of conditional (creaturely) freedom, at whatever historical stage the latter may find itself-whether it is close to the former, alienated from it or coming back to its real self" (Balthasar 1990, p. 119). For a major discussion of these themes (Dalzell 2000). 
language shows this contest playing out across the drama of history to be freedom-in-relationship and not some mechanistic tragedy binding God and world to a pre-determined "fate" (Balthasar 1990, p. 196). Human freedom operates like the relational quality of the Trinity; true freedom makes room for others. ${ }^{47}$ Therefore, God's will for the world is not like the "fate" of the Greek tragedies but, rather, a call to intimate fellowship, bolder action, and unique importance in the role for each person (Balthasar 1990, p. 296). But where ordinary social roles might become closed loops and traps, missions actualize identity in freedom. Dramatic language highlights the particularity and importance of each human response because freedom, understood theodramatically, reflects the act-quality of God's Triune inner life (Balthasar 1990, p. 256). Freedom becomes dramatic only in action, hence why theodramatics help von Balthasar understand and interpret the God who is an eternal free act of love. Theatre-making requires similar room for free improvisation. A balance between infinite and finite freedom appears in how the actors in White Rabbit Red Rabbit make their own free choices that could never have been intended or fated by Soleimanpour's script. The play depends on the freedom for improvisation of its actors: "Honestly, I don't know WHAT this actor is doing" (Soleimanpour 2017, p. 3). The play's author also expresses something that "tastes like FREEDOM" from political and temporal fixedness: drama escapes ordinary finitude insofar as the play and its "timeless travel" through space and time "with no need for a passport" in ways the historical Soleimanpour could not (Soleimanpour 2017, p. 21).

Obedience. Divine-infinite freedom calls for human-finite freedom's obedience. So too on stage. The free improvising of White Rabbit Red Rabbit's theatrical realization points to its structural and thematic emphasis on obedience. The play anticipates and requires obedience to the mission of the script. Disobeying the script stops the performance, even though Soleimanpour makes room for improvised jokes and commentary that divert from the printed word. To continue, the text must be freely obeyed. The instructions to the actor include how "You might think you want to add something. If so, that's fine. But tell the audience its yours" (Soleimanpour 2017). (This might be signaled with a physical choice: at the performance I saw, the actor raised a hand whenever deviating from Soleimanpour's script.) So too, von Balthasar's theology hinges on free obedience to mission. Obedience is "becoming transparent to one's mission" (Balthasar 1988, p. 289). In another sense, however, von Balthasar sees theatrical obedience to be reciprocal: "We must reject any suggestion that would make the actor into the author's servant and equally any that would degrade the author to the level of a mere cobbler of plays for the actor" (Balthasar 1988, p. 283). The Director-Spirit holds freedom and obedience together and works to make the performance interpretation relevant for the present audience. $^{48}$ The Actor-Son performs in perfect obedience to the will of the Author-Father. Freedom, then, finds expression in the kenotic obedience of the Christ or Soleimanpour's actors. Even bracketing theological overtones, Soleimanpour's play confounds the assumption that freedom and obedience are contradictions in terms. The improvisatory play of such red rabbits will be both free and obedient at the same time: "MAY GOD SAVE YOU!" (Soleimanpour 2017, p. 24).

Sacrificial Death. As von Balthasar writes, "It follows quite naturally that if, obedient to his mission, a person goes out into a world that is not only ungodly but hostile to God, he will be led to the experience of Godforsakenness" (Balthasar 1988, p. 647). The Christ, the Actor-Son, plays a human script that ends in sacrificial death. Like the finale to White Rabbit Red Rabbit, obedience to the will of the Author-Father includes the real possibility of death: "infinite freedom appears on the stage in the form of Jesus Christ's 'lowliness' and 'obedience unto death'" (Balthasar 1990, p. 250). The final volume of the Theo-Drama makes much of the Christ's willingness to endure the Godforsakenness of

47 The finite freedom of existence consists in the ability to say "I am unique, but only by making room for countless others to be unique" (Balthasar 1990, p. 209).

48 The director guides the play like the Holy Spirit guides the modern church toward a "valid aggiornamento" (Balthasar 1988, p. 303). 
rejection on the cross, death, and in descent into hell. ${ }^{49}$ The interpretive key for von Balthasar is always the Christ's cry of dereliction and abandonment: "my God, my God, why have your forsaken me" (cf. Psalm 22:1, Mark 15:34, Matt. 27:46). This "total self-giving" over into Godforsakenness by God the Son becomes a divine "super-death", a "radical 'kenosis"" that lets go without holding onto any remainder (Balthasar 1998, p. 84)..$^{50}$ Theodrama always happens against the horizon of the final act, of sacrifice and death.

For von Balthasar, the Christ's obedience unto death occurs without any consoling knowledge of future resurrection. The Christ, as the incarnate Son of God, freely surrenders divinity back to God in solidarity with creatures. Von Balthasar calls this the Christ's "laying up" of his "divine power and glory" with God the Father where he says "this concept only summarizes" the kenotic hymn in Philippians 2 (Balthasar 1998, p. 257). ${ }^{51}$ Kenotic "laying up" permits von Balthasar to talk about the Christ's absent foreknowledge of the resurrection because "the Father's presence was so veiled that the Son experienced God-forsakenness" (Balthasar 1998, p. 257). The horror of crucifixion and abandonment and travel into unknown hellish territory would be truly human experiences ${ }^{52}$ Like the actor in White Rabbit Red Rabbit who obediently drinks a poisoned draught in deference to the will of the writer, so too does the Christ obediently defer to God the Father's will and drink from a cup that leads to death (cf. Matt. 26:39, Mark 14:36, Luke 22:42). ${ }^{53}$ Parallels abound between the obedience and suicide plot in White Rabbit Red Rabbit and the Passion narrative of the Christ's kenotic self-sacrifice. Theodramatics give language to the play's mysterious and risky encounters with the unknown. Like von Balthasar's Jesus, Soleimanpour's actors "lay up" theatrical foreknowledge in solidarity with the audience. The audience disperses like the disciples, newly formed "red rabbits". Soleimanpour's play ends on the Balthasrian "Holy Saturday", and, like von Balthasar, we can only speculate about the actor's inner experience of theatrical forsakenness and "super-death". Even the script suggests that the actor may want to linger and reflect for a moment in the liminal space at the end of the show.

\section{Whose Line Is It Anyway?}

With these themes in mind, I conclude with a brief analysis of the unique instance of White Rabbit Red Rabbit where I performed as a member of its audience. As part of a gift to a friend, I attended a performance of its off-Broadway run in 2016. ${ }^{54}$ This run featured celebrities playing the role of the actor on stage. The contradiction of a singular event in an ongoing commercial run off-Broadway confirms the importance of the play's production history. A single "production" (that is, the same producers-Tom Kirdahy and Devlin Elliott-with the same scenic design and props) could be realized through as

49 Rejecting God is sinful, so the forsaking of the Son as $\sin$ by the Father could only be done by God. "This is the central mystery of the theodrama: God's heightened love provokes a heightened hatred that is as bottomless as love itself (John 15:25)" (Balthasar 1998, p. 285).

50 Critics, on both von Balthasar's right and on his left, have cautioned against such swift movement from divine love to trinitarian generation to kenosis to death to descent into hell and its theological and ethical implications, as in (Tonstad 2016, p. 38).

51 Here, von Balthasar, somewhat controversially, follows language drawn from Adrienne von Speyr's visionary writing. The confusing phrase "laying up"-presented in scare marks in both English and German-is a literal translation of "Hinterlegung", a word that carries a range of economic connotations: deposit, escrow, filing, lodgment.

52 Kenotic "laying up" also refers to the Christ's veiled God-consciousness (in Fredrich Schleiermacher's turn of phrase), including von Balthasar's position that Jesus the Christ did not have access to perfect self-knowledge of himself as the Son of God throughout the experience of the Passion. On Christ's knowledge and mission, see (Balthasar 1992, p. 149ff).

53 Theodramatic structures, whether in von Balthasar or Soleimanpour, are dangerous precisely in the ways they might be misread in praise of suicide. A poisoned cup also recalls the double suicide at the end of Romeo and Juliet, but kenotic self-sacrifice gives over for the sake of another. Romeo and Juliet's ending, some "reconciliation of the hostile families over the dead bodies of their children", receives no endorsement (Balthasar 1988, p. 472). A more theodramatic conclusion-and one that follows Soleimanpour's warning to audience-rabbits who mindlessly obey political and social pressures-includes the mission to act differently. Such a take on theatrical suicide appears at the end of Shakespeare's play in the version described in (VanZandt Collins 2020, p. 7).

54 Thanks to Jewelle Bickel for the tickets and to Justin E. Crisp with whom I saw the play and enjoyed much conversation that first formed the ideas in this essay. 
many different interpretations of White Rabbit Red Rabbit as there were performers and performances. I attended on 4 April 2016, with master improvisor Wayne Brady as our actor. I cannot remember my number (perhaps 34?), but Brady complimented the gusto and volume in my vocal projection.

Meaning cascaded onto the play through free obedience to coincidences unimaginable to the writer. When the day's date was correctly given as 4 April 2016 by a member of the audience, a voice rapidly followed proclaiming something like "the anniversary of Martin Luther King Jr.'s assassination". The date changed the meaning of the play. The Blackness of the actor's body bestowed layers of significance onto Soleimanpour's text previously illegible (at least to me) as racialized. Should the colored rabbits of the title-white and red-point toward something about race? Do its scenes of playful cruelty to animals evoke systemic racism? Brady paused and took stock of the situation. The play (billed as a comedy) generates all sorts of what Ricoeur might call "surplus meaning" in its performance. Brady balanced a night of improvisational silliness with palpable reverence for the play's themes about the spectacle of death, self-sacrifice, playful freedom, and obedience. Following the production's established convention to signal when breaking from the script, Brady raised his hand to ask "Do you see what he's saying here?" The play never stopped being funny, but its meditations about the danger of absolute obedience took on specificity in surplus meanings created by the interpretive work of a famous Black actor in the United States guiding his room full of players on this anniversary.

One section of Soleimanpour's script enumerates seventeen "ways to commit suicide", perhaps meant to be improvised (Soleimanpour 2017, pp. 46-47). The page can be elongated and played for laughs by miming each item as a theatrical prompt. In some ways, that suicide list in White Rabbit Red Rabbit (far from its only reference to self-sacrifice or self-caused death) recapitulates rehearsal improvisation games that heighten melodrama to the point of absurdity. Brady refused to play the suggestions in order to underscore the seriousness of the play's questions. (He made one exception for a slip of the tongue-I cannot remember exactly, perhaps from "hunger strike" to "hunger shark" (Soleimanpour 2017, p. 47) -and consented to improvise death by shark attack. Brady made a hilarious squeaking noise as he donned a mimed "swimming cap".) Brady made no special emphasis to the phrases "hanging" or "provoking the police" in his performance (Soleimanpour's suicide options number seven and seventeen, respectively). But the spectacle of a Black man's death (even if it is "very probably FAKE") to entertain the (predominantly) white audience can turn the focus of theodramatic interpretation. The text connects this singular performance with the moment of composition, but the context of the memory of King's assassination and the persistence of anti-Black racism and violence in the United States situated the play's Showtime in a third crosscurrent of history. As James H. Cone puts it, "The lynching tree is the cross in America" (Cone 2011, p. 158.) The play's freedom for interpretation beyond its textual boundaries finds in this actor, theatrically "poisoned" and sacrificed in obedience to the plot, an image of the lynched Christ. ${ }^{55}$ Brady's performance brought, in M. Shawn Copeland's term, enfleshed theological meanings to rupture expectations about the play's theodramatic form (Copeland 2009).

Performance generates meanings beyond what might be presumed to be intended. These include von Balthasar's presumptions about directors that impose the politics of the present onto drama (or theology). ${ }^{56}$ "Now our creaturely becoming has a share in the ineffable 'becoming' of the Divine Being" (Balthasar 1998, p. 131). The play performs its own theatrical inverse of theodramatic reality: the play stages what one dares to hope is a virtual (Soleimanpour's "fake") manifestation of the actor's

55 Dolores Williams, by contrast, calls into question the notion of kenotic substitution of the Christ's death for the sake of the world as "surrogacy". Williams critiques the image of surrogacy that rhetorically connects the historical experience of Black women in the United States with Christian theologies of substitutionary atonement. (See Williams 1991, p. 9ff.) See also Williams discussion of the rhetorical power of theological symbols in (Williams 1993).

56 "Here the director meets his hardest task: he must be committed enough to make the play relevant and at the same time civilized enough not to equate this here-and-now relevance with a narrow doctrine of society. The theatre is a political reality, in a lofty and noble sense, but it should not be misused for political party propaganda" (Balthasar 1988, p. 303, emphasis original). 
forsakenness by the playwright in potential self-sacrifice. Dramatic art operates in Soleimanpour to disclose reality in the drama of history. White Rabbit Red Rabbit makes present a threat for theatre's madness and violence to become real. But such is the threat of free obedience to any script. One never knows for sure until after making choices. The play concludes with an audience exiting while the actor lays and lies "dead". Brady remained still, and the room of audience-players departed in a reverential silence usually reserved for the sacred.

Alejandro Garcia-Rivera argues that theological aesthetics in the tradition of von Balthasar can become a means for "lifting up the lowly" (García-Rivera 1999, pp. 187-96). ${ }^{57}$ Time and bodies confront Soleimanpour's text to tell complex and ambiguous stories: Iranian political oppression, anti-Blackness in the United States, a cosmic theodrama. White Rabbit Red Rabbit questions the closure of theatrical or theological interpretation in obedience to a singular vision of possibility. Brady's improvisation can be one way of enfleshing what Ashon T. Crawley calls "otherwise possibility" (Crawley 2017). ${ }^{58}$ But the singularity of White Rabbit Red Rabbit carries with it the melancholy of a loss. Like von Balthasar's notion of the history of the world illumined by the fact of the Christ's incarnation, the play can only be played once as an actor without knowledge of what comes next. Now, with awareness and dramatic irony, the play opens for participation in infinite numbers of other credible interpretations. Players return to participate in yet another instantiation of its "eph-hapax" meaning. Anyone who has seen or read the play now can produce it with Soleimanpour's permission included in the script (Soleimanpour 2017, p. 55). ${ }^{59}$

White Rabbit Red Rabbit aims for some real connection via the timelessness and spacelessness of words made present. Even after its performance, White Rabbit Red Rabbit gestures toward creaturely invitation to resurrected life as something akin to von Balthasar's theology of all creature's ability to participate in the Christ's, the Actor-Son's death. Death's "non-time" has been engulfed by God's eternity. ${ }^{60}$ Perhaps it can be better put in the language of Blanchot's "feeling of lightness" of "the infinite opening up?" when writing the experience of a halted execution: "I know, I imagine that this unanalyzable feeling changed what there remained for him of existence. As if the death outside of him could only henceforth collide with the death in him. 'I am alive. No, you are dead'" (Blanchot 2000, pp. 8-9). Blanchot's phrase now applies to Brady (still alive and still working as an actor, at least at the time of my writing, still alive and still working on this essay) and to everyone else complicit in a production of White Rabbit Red Rabbit. So too is the confrontation between Blanchot's phrase and the work still left to do for every player in a social drama so tacitly complicit in anti-Black violence. White Rabbit Red Rabbit calls attention to present and active bodies, especially those whose surplus meanings fail to obey arbitrary genre expectations. The play's theodramatic Showtime displays religious and theatrical co-present and co-presence to be freeing even if already written: "I did not see you, but in a way, I met you. And I am happy. The end" (Soleimanpour 2017, p. 63).

Funding: This research received no external funding.

57 An experience of the Beautiful—in community—-lifts up the lowly because "The aesthetic sign 'calls' the heart to discern original Beauty so that it may orient itself towards a Beautiful end" (García-Rivera 1999, p. 190).

58 For Crawley, "enfleshment [is] distinct from embodiment ... enfleshment is the movement to, the vibration of, liberation and this over and against embodiment that presumes a subject of theology, a subject of philosophy, a subject of history" (Crawley 2017, p. 6).

59 There can be no easy legal identification of the play's writer, called Nassim Soleimanpour, and the owner of the play's intellectual property, presumably the same Nassim Soleimanpour. The print version contradicts the play's text; its copyright page asserts "All rights whatsoever in this play are strictly reserved and application for performance etc. should be made ... to Nassim Soleimanpour c/o Oberon Books. No performance may be given ... and not alterations may be made ... without the author's prior written consent". But is such consent not already contained within the play's text?

60 "In his Resurrection, Jesus has already taken the whole of transitory time (including life and death) with him into eternal life which was the source of his constant obedience to the Father's commission. This means he also recapitulated the 'non-time' of the dead. It also means that the Risen One does not live in some 'intermediate time' before the 'end of the world'" (Balthasar 1998, p. 128, with internal references to Adrienne von Speyr). Due diligence notes that while von Balthasar also appeals to the poetics of wideness, he more frequently invokes military-sexual metaphors for God's relationship to the world and its time. For example, "God intends not only to dominate creaturely time from above but to embed it, with all its created reality, in his eternal time" (Balthasar 1998, p. 127). 
Conflicts of Interest: The author declares no conflict of interest.

\section{References}

Balthasar, Hans Urs von. 1973. Theodramatik I: Prolegomena. Einseideln: Johannes Verlag.

Balthasar, Hans Urs von. 1982. The Glory of the Lord: A Theological Aesthetics, Volume I: Seeing the Form. Edited by Joseph Fessio S. J. and John Riches. Translated by Erasmo Leiva-Merikakis. San Francisco: Ignatius.

Balthasar, Hans Urs von. 1988. Theo-Drama I: Prolegomena. Translated by Graham Harrison. San Francisco: Ignatius.

Balthasar, Hans Urs von. 1990. Theo-Drama II: Dramatis Personae: Man in God. Translated by Graham Harrison. San Francisco: Ignatius.

Balthasar, Hans Urs von. 1992. Theo-Drama III: Dramatis Personae: Persons in Christ. Translated by Graham Harrison. San Francisco: Ignatius.

Balthasar, Hans Urs von. 1994. Theo-Drama IV: The Action. Translated by Graham Harrison. San Francisco: Ignatius. Balthasar, Hans Urs von. 1998. Theo-Drama V: The Last Act. Translated by Graham Harrison. San Francisco: Ignatius. Blanchot, Maurice. 1982. The Space of Literature. Translated by Ann Smock. Lincoln: University of Nebraska Press. Blanchot, Maurice. 2000. The Instant of My Death. Translated by Elizabeth Rottenberg. Edited by Werner Hamacher and David E. Wellbery. Stanford: Stanford University Press.

Boal, Augusto. 1985. Theatre of the Oppressed. New York: Theatre Communications Group.

Bouchard, Larry D. 2011. Theater and Integrity. Evanston: Northwestern University Press.

Bouchard, Larry D. 2020. Religion and the Limits of Metatheatre in Our Town and Sunday in the Part with George. Religions 11: 94. [CrossRef]

Brook, Peter. 2019. The Empty Space. New York: Scribner. First published 1968.

Carpenter, Anne M. 2015. Theo-Poetics: Hans Urs von Balthasar and the Risk of Art and Being. Notre Dame: Notre Dame University Press.

Chambers, Claire Marie. 2017. Performance Studies and Negative Epistemology: Performance Apophatics. London: Palgrave Macmillan.

Cone, James H. 2011. The Cross and the Lynching Tree. Maryknoll: Orbis.

Copeland, M. Shawn. 2009. Enfleshing Freedom: Body, Race, and Being. Minneapolis: Fortress.

Crawley, Ashon T. 2017. Blackpentecostal Breath: The Aesthetics of Possibility. New York: Fordham University Press.

Dalzell, Thomas G. 2000. The Dramatic Encounter of Divine and Human Freedom in the Theology of Hans Urs von Balthasar, 2nd ed.Berne: Peter Lang.

Dox, Donalee. 2016. Reckoning with the Spirit in the Paradigm of Performance. Ann Arbor: University of Michigan Press.

Fink, Eugene. 2016. Play as Symbol of the World. Translated by Ian Alexander Moore, and Christopher Turner. Bloomington: Indiana University Press. First published 1960.

Floor, Willem. 2005. The History of Theater in Iran. Washington: Mage.

Frost, Anthony, and Ralph Yarrow. 2007. Improvisation in Drama, 2nd ed. New York: Palgrave Macmillan.

Gadamer, Hans-Georg. 1989. Truth and Method, rev. ed. Translated by Joel Weinsheimer, and Donald G. Marshal. New York: Continuum.

García-Rivera, Alejandro. 1999. The Community of the Beautiful: A Theological Aesthetics. Collegeville: Liturgical Press.

Gillespie, Charles A. 2019. Drama Alone is Credible: Hans Urs von Balthasar and the Interpretive Work of Theatre and Performance in Twentieth-Century Christian Thought. Ph.D. dissertation, University of Virginia, Charlottesville.

Gioia, Michael. 2016. EXCLUSIVE: 17 Outrageous Moments from the Run of White Rabbit Red Rabbit. Playbill. December 19. Available online: https://www.playbill.com/article/exclusive-17-outrageous-moments-fromthe-run-of-white-rabbit-red-rabbit (accessed on 10 February 2020).

Goffman, Erving. 1959. Presentation of Self in Everyday Life. Garden City: Doubleday.

Grimes, Ronald L. 2014. The Craft of Ritual Studies. Oxford: Oxford University Press.

Hart, Kevin. 2004. The Dark Gaze: Maurice Blanchot and the Sacred. Chicago: University of Chicago Press.

Huizinga, Johann. 1950. Homo Ludens: A Study of the Play-Element in Culture. New York: Roy. First published 1944.

Kapp, Volker, Helmuth Kiesel, and Klaus Lubbers, eds. 2000. Theodramatik und Theatralität: Ein Dialog mit dem Theaterverstandnis von Hans Urs von Balthasar. Berlin: Duncker \& Humblot.

Kilby, Karen. 2012. Balthasar: A (Very) Critical Introduction. Grand Rapids: Eerdmans.

Kushner, Tony. 2004. Homebody/Kabul. New York: Theatre Communications Group. 
Mapari, Dimple D. 2017. Paradigm Shift in the Genre; Drama, with Reference to 'White Rabbit Red Rabbit. LangLit 4: 2. Martin, Jennifer Newsome. 2015. Hans Urs von Balthasar and the Critical Appropriation of Russian Religious Thought. Notre Dame: Notre Dame University Press.

Mason, David V. 2019. The Performative Ground of Religion and Theatre. New York: Routledge.

Performance Group. 1970. Dionysus in 69. Edited by Richard Schechner. New York: Farrar, Straus and Giroux. Quash, Ben. 2005. Theology and the Drama of History. Cambridge: Cambridge University Press.

Ricoeur, Paul. 1976. Interpretation Theory: Discourse and the Surplus of Meaning. Fort Worth: TCU Press.

Ricoeur, Paul. 1984. Time and Narrative. 3 vols. Translated by Kathleen McLaughlin, and David Pellauer. Chicago: University of Chicago Press.

Rocci, Aida. 2017. Nassim Soleimanpour and the Manila Envelope Theatre. The Theatre Times. October 18. Available online: https://thetheatretimes.com/nassim-soleimanpour-manila-envelope-theatre/ (accessed on 10 February 2020).

Schindler, David C. 2004. Hans Urs von Balthasar and the Dramatic Structure of Truth: A Philosophical Investigation. New York: Fordham.

Schneider, Rebecca. 2014. Theatre \& History. London: Red Grove Press, p. 7.

Scola, Angelo. 1995. Hans Urs von Balthasar: A Theological Style. Grand Rapids: Eerdmans.

Shakespeare, William. 2006a. As You Like It. Edited by Juliet Dusinberre. Arden Shakespeare, 3rd ser. London: Thomson Learning.

Shakespeare, William. 2006b. Hamlet, Edited by Ann Thompson and Neil Taylor. , Arden Shakespeare, 3rd ed. London: Thomson Learning.

Soleimanpour, Nassim. 2017. White Rabbit Red Rabbit E BLANK. London: Oberon.

Stanislavski, Konstantin. 2008. An Actor's Work: A Student's Diary. Translated by Jean Benedetti. New York: Routledge. Tanner-Kennedy, Dana. 2020. Gertrude Stein and the Metaphysical Avant-Garde. Religions 11: 152. [CrossRef] Tonstad, Linn Marie. 2016. God and Difference: The Trinity, Sexuality, and the Transformation of Finitude. New York: Routledge. Ubersfeld, Anne. 1999. Reading Theatre. Translated by Frank Collins. Toronto: University of Toronto Press.

Vander Lugt, Wesley, and Trevor Hart, eds. 2015. Theatrical Theology: Explorations in Performing the Faith. Cambridge: Lutterworth Press.

Vanhoozer, Kevin. 2005. The Drama of Doctrine: A Canonical-Linguistic Approach to Christian Theology. Louisville: Westminster John Knox Press.

Vanhoozer, Kevin. 2014. Faith Speaking Understanding: Performing the Drama of Doctrine. Louisville: Westminster John Knox Press.

VanZandt Collins, Michael. 2020. Toward Witnessing the Other: Syria, Islam, and Frans van der Lugt. Religions 11: 174. [CrossRef]

Walatka, Todd. 2017. Von Balthasar \& the Option for the Poor: Theodramatics in the Light of Liberation Theology. Washington: The Catholic University of America Press.

Wickstrom, Maurya. 2018. Firey Temporalities in Theatre and Performance: The Initiation of History. London: Methuen. Wiles, David. 2014. Theatre E Time. London: Red Grove Press.

Williams, Dolores S. 1991. Black Women's Surrogacy Experience and the Christian Notion of Redemption. In After Patriarchy: Feminist Transformations of the World Religions. Edited by Paula M. Cooey, William R. Eakin and Jay B. McDaniel. Maryknoll: Orbis.

Williams, Dolores S. 1993. Sisters in the Wilderness: The Challenge of Womanist God-Talk. Maryknoll: Orbis Books.

Youngs, Ian. 2013. Playwright Nassim Soleimanpour Sees His Own Play. BBC News. February 26. Available online: https://www.bbc.com/news/entertainment-arts-21577030 (accessed on 10 February 2020).

(C) 2020 by the author. Licensee MDPI, Basel, Switzerland. This article is an open access article distributed under the terms and conditions of the Creative Commons Attribution (CC BY) license (http://creativecommons.org/licenses/by/4.0/). 
Article

\title{
Nora's Ironic Longing for Christlike Love: Self-Sacrifice, Self-Love, and the "Religion of Torvald" in Ibsen's A Doll House
}

\author{
David V. Urban \\ Department of English, Calvin University, Grand Rapids, MI 49546, USA; dvu2@calvin.edu
}

Received: 7 December 2019; Accepted: 16 June 2020; Published: 28 June 2020

\begin{abstract}
This essay argues that in Ibsen's A Doll House, both Nora and her husband, Torvald Helmer, exhibit a "religion of Torvald" characterized by their respective devotion to Torvald himself. However, while Torvald's devotion to himself is characterized by self-love and self-centeredness, Nora's "religion of Torvald" is based on her expectation that Torvald will exhibit the Christlike office of bearing Nora's sins by proclaiming himself guilty of her crime of forgery, thus rendering her blameless. After Torvald shatters Nora's expectations by reacting with abuse and cowardice to the news of Nora's forgery and Krogstad's consequent blackmail, Nora loses her previous faith in Torvald and instead exhibits a preoccupation with her own self that, ironically enough, imitates the self-love of the "religion of Torvald" that Torvald has practiced all along.
\end{abstract}

Keywords: Ibsen; Doll's House; Nora; Torvald; Helmer; Christianity; Christ; religion; sacrifice; idealism; Calvin

In the final scene of $A$ Doll House (1879), soon after Nora announces that she is leaving Torvald Helmer and their children, Torvald protests: "[I]sn't there one everlasting guide you can turn to? Where's your religion?" (p. 193). ${ }^{1}$ The religion he speaks of is Christianity, toward which Nora now expresses great uncertainty, responding "Oh, Torvald, I'm really not sure what religion is" (p. 193). But if Nora has suffered a loss of faith, it is Torvald's own lethargy toward Christian practice that largely precipitates Nora's religious confusion. Indeed, Torvald's essentially imperceptible Christian piety is dwarfed throughout the play by his devotion to himself-a habitual self-focus, quite opposed to Christianity, that I will call the "religion of Torvald". Significantly, Nora also practices a "religion of Torvald" - albeit, as we shall discuss, one whose perspective is substantially different from her husband's-before Torvald's cowardly response to Krogstad's blackmail shatters her faith in him. But while Nora, like her husband, lacks serious Christian commitment, a closer examination of her faith in Torvald reveals that her finally jettisoned "religion of Torvald" was ironically dependent on his presumed adherence to New Testament teachings commanding husbands to sacrificially love their wives, teachings Torvald fails to follow when Nora most expects and needs such sacrificial devotion, a failure which precipitates Nora's devastating decision to imitate, however unconsciously, the self-focused version of the "religion of Torvald" that her husband has practiced all along. Throughout this essay, I will use a broadly Reformed Christian perspective to analyze the play's different manifestations of the "religion of Torvald," seeking to understand Nora and Torvald from the framework of traditional continental Protestantism and beyond the immediate context of contemporary Norwegian Lutheranism.

1 All references to A Doll House are from Fjelde's translation (Ibsen 1978) and will be cited parenthetically. 
Throughout nearly all of the play, Nora demonstrates a deep and abiding faith in Torvald; indeed, we may rightly suggest that "Nora has ensconced Torvald as her god" (Lavender 2008, p. 122). One example of such faith is evident late in Act I while Nora trims the Christmas tree, emotionally flustered by Krogstad's having just confronted her with his knowledge of the forgery by which she obtained a loan from Krogstad years ago. Nora's fearful response to his confrontation is to call on Torvald in his absence, implicitly hoping that her pleasing appeals to him will be efficacious and move him to shield her from danger. Joshua Lavender observes, "As Nora trims the Christmas tree, the traditional emblem in the modern Western world for the birth of Jesus Christ, her private musings resemble an adulatory prayer or chant: 'I'll do anything to please you Torvald. I'll sing for you, dance for you' [p. 150]" (Lavender 2008, p. 120). The irony of Nora's Christmastime faith in someone other than Christ himself strikingly cuts against contemporary European culture's expectation that the "domestic hearth" cultivates an explicitly Christian feminine spirituality; indeed, far from Nora's exemplifying the Victorian ideal of the "Festival of Christmas" "lift[ing] woman to her supreme place in the family circle in the reflection of the glory of the Virgin Mother" (Hastie 1890, p. ix), Nora's devotion to Torvald here effectively replaces what would ordinarily be presumed to be a homemaker's feminine devotion to the savior Christ. ${ }^{2}$ Rather, Nora, while trimming her Christmas tree, cultivates her devotion to the one she believes will be her savior, Torvald. Another example of Nora's faith in Torvald appears in Act II, just after Krogstad informs Nora of his scheme to blackmail Torvald lest Krogstad reveal her crime. Overcome with fear as she prepares to practice her dance for the masquerade party they will attend the next evening, Nora tells Torvald, "I can't get anywhere without your help. [ ... ] Direct me. Teach me, the way you always have. [ ... ] You've got to teach me to the very last minute" (pp. 172-74). Here, Nora's faith in Torvald expresses her reverent dependence on him in the face of danger even as it satisfies his desire for such reverence, a satisfaction expressed when Torvald says he'll "gladly" fulfill Nora's request that he "[d]irect" her (p. 173), telling her, "I'm totally at your service-you little helpless thing" (pp. 172-73). Indeed, Torvald's response perhaps suggests that he will demonstrate the kind of sacrificial servant-leadership for which Nora, as we shall see, longs.

In any case, although Nora and Torvald each demonstrates a "religion" that focuses on Torvald, Nora holds a significant point of "doctrine" that Torvald does not. For while Torvald's devotion to himself, as we shall soon discuss, centers on his own happiness and reputation, Nora's faith in Torvald is based largely on her belief that he will sacrifice himself completely for her. However erroneously, she is convinced that his loving selflessness will transcend the sacrifice she made early in their marriage when she worked secretly—and illegally — to obtain from the disreputable Krogstad, via the aforementioned loan, the money needed to save Torvald's life through a vacation to a warmer climate. And, although Nora has long been celebrated as a "romantic standard bearer of the feminist cause" (Tufts 1986, p. 140), her idealized perception of Torvald, ironically enough, strongly resembles the Christian Scriptures' model for husbands. In his epistle to the Ephesians, Saint Paul writes, "Husbands, love your wives, just as Christ loved the church and gave himself up for her" (5:25). ${ }^{3}$ Nora first demonstrates such belief in Torvald in Act II, when, just before Dr. Rank confesses his love for her, she tells him, "You know how deeply, how inexpressibly dearly Torvald loves me; he'd never hesitate a second to give up his life for me" (p. 165). Here, Nora's expectation of Torvald's sacrifice for her is in keeping with a traditional Reformed Christian understanding of a husband's sacrificial duties to his wife. As John Calvin comments on Ephesians 5:25: "Let husbands imitate Christ in this respect, that he scrupled not to die for his church" (Calvin n.d., p. 259). Significantly, at least on a material level, Nora's belief in Torvald can be seen as largely accurate. William A. Johnsen notes that the industrious Torvald "worked himself into a state of self-sacrifice in their first year of marriage" (Johnsen 2011,

2 See also Friedrich Schleiermacher's Christmas Eve dialogue for laudatory descriptions and portrayals of such feminine Christian spirituality, best exemplified by the homemaker Ernestine (Schleiermacher 1890, passim).

3 All biblical quotations are from (Bible 1984). 
p. 196), a self-sacrifice that, according to his physician, almost cost the exhausted Torvald his life and necessitated the couple's vacation to Italy. ${ }^{4}$

Nora's faith in Torvald, however, also includes her belief that, because of his superlative love for her, he would for her sake sacrifice both his life and his reputation - the latter being something, as we shall presently discuss, that Torvald will absolutely refuse to do. (Significantly, Nora's aforementioned sacrifice to save Torvald's life via an illegal loan from Krogstad-what we might call her "secret redemption" of Torvald-arguably demonstrates her own willingness to sacrifice her reputation for his sake, a sacrificial act she expects Torvald to match or transcend for her benefit. ${ }^{5}$ ) Moreover, Nora's longing for such Christlike sacrificial love from Torvald is so great that, when he fails her "religious" expectations of him, Nora abandons him. These dynamics are supremely evident in the couple's final conversation. Shortly before leaving Torvald, Nora reveals to him the "miracle" she had expected would deliver her from Krogstad's blackmail: "I never for an instant dreamed that you could give in to his terms. [ ... ] I was so utterly sure that you'd step forward, take the blame on yourself and say: I am the guilty one" (p. 194). Contrary to Nora's hopes, Torvald responds to Krogstad's first letter by rejecting her, blaming her for his lost happiness, and announcing that her fraud "has to be hushed up at any cost" (p. 188), a petty tirade that reveals both "the smallness of Torvald's character" (Brooks 2013, p. 15) and "the different codes under which [Nora] and her husband had been living" (Mahaffey 2010, p. 58). But Nora's initial expectation that Torvald would take her guilt and shame upon himself to clear her name is curiously reminiscent of Paul's depiction of Christ's loving sacrifice for the church—something Paul calls husbands to imitate—in order to render his church "blameless" (Eph. 5:27). Nora's desire also recalls Paul's teaching that Christ, "who had no sin", chose to "be sin for us, so that in him we might become the righteousness of God" (2 Corinthians 5:21). Ironically, the impious Nora articulates a now-destroyed hope that Torvald would act in a way that resembles Christ's model for husbands and indeed Christ himself, ${ }^{6}$ even as she expected that the god whom she served in her misguided "religion of Torvald" would offer himself as a kind of substitutionary atonement for her sake.

For his part, Torvald demonstrates stunning ignorance toward the crux of the Christian religion he professes at the end of the play. Replying to Nora's revelation of the "miracle" she was expecting, Torvald responds incredulously to the idea that he would sacrifice his reputation for her sake. He says, "I'd gladly work for you day and night, Nora-and take on pain and deprivation. But there's no one who gives up honor for love" (p. 194, italics added). But this specific sacrifice is exactly what Paul reports Jesus doing: He gave up the honor he shared with God the Father and chose instead to die an accursed death because of love for his church (cf. Philippians 2.6-8, Galatians 3.13-14, Eph. 5.25-27), and such is the kind of self-giving love Nora expected from Torvald.

Reflecting on Torvald's subsequent hollow declaration of his superlative love for Nora, Toril Moi affirms that Nora "demands nothing short of a revolutionary reconsideration of the meaning of love" (Moi 2006, p. 278). Moi is undoubtedly correct that Nora demands a definition of love radically different from Torvald's understanding of love's meaning. Even though Nora is not thinking in Christian terms,

4 Speaking to Torvald's devotion as a provider for Nora, Evert Sprinchorn writes that Torvald "has given Nora all the material things and all the sexual attention that any young wife could reasonably desire" (Sprinchorn 1980, p. 121). A similar understanding of Torvald was offered by Royal Shakespeare Company actor Barrie Ingham, who played Torvald in a 1979 University of Texas production of A Doll House. According to Yvonne Shafer, "Ingram played Torvald as a character who loved his wife [ ... ] who viewed himself as a strong man protecting his lovely, charming wife" (Shafer 1985, p. 31).

5 Emphasizing the irony of Nora's saving the life of her "self-aggrandizi[ng]" husband, Chengzhou He suggests that in her role as Torvald's savior, Nora "turns out to be more masculine than feminine" (He 2008, p. 143).

6 Nora's longing for the superlative demonstration of a husband's self-sacrifice for his wife is germane to the subject of the "logic of complementarity" that Adam Beyt addresses in his article for this Special Issue (Beyt 2019). While I will not here address Beyt's critique of this subject, I will point out that the notion of the "logic of complementarity" is complicated in Torvald and Nora's relationship both by Nora's stated desire to imitate and indeed supersede Torvald's anticipated self-sacrificial love for his wife and by her subsequent, however unconscious, imitation of her husband's self-love that transcends his love for his wife. 
she states the desire that Torvald demonstrate love like Christ's sacrifice for his beloved. This is the sort of sacrifice that calls husbands, in Calvin's words, to "cherish" their wives with "no ordinary love" but one that follows Christ's sacrificial "example" (Calvin n.d., p. 258). I argue that framing Nora's ironic longing in dialogue with a Reformed Christian understanding of self-sacrifice complicates the feminist reading that Moi offers and the play's ending invites. Indeed, "religion" plays a role in her decision. Nora's choice to leave comes only after Torvald fails to offer such love, thus shattering her faith in him. It is fitting, then, that Nora's admission of the anticipated "miracle" closely follows Torvald's question, "Where's your religion?"7 Her immediate answer, "Oh Torvald, I'm really not sure what religion is" (p. 193), is entirely appropriate for someone whose faith has just been shattered by the object of that faith, for in his petty tirade, Nora has recognized Torvald's "inadequacy as her god" (Lavender 2008, p. 124).

Nora's response horrifies Torvald, but were he to examine himself honestly, he would recognize that he himself has demonstrated no tangible evidence of Christian faith. Indeed, Torvald's appeal to "religion" rings embarrassingly hollow-a mere ineffectual exercise of "patriarchal power" (Langås 2005, p. 150) ${ }^{8}$ —in light of his behavior throughout the play. Significantly, Torvald showed no concern for Christian religion before their conflict, even though he had numerous earlier opportunities, which I shall outline below, to demonstrate Christian faith were Christianity truly important to him. Strikingly, the play takes place on Christmas Eve, Christmas, and the day following, but neither Christ nor church are mentioned in the Helmer household, even when Torvald and Nora discuss matters of Christmas early in the play. Later in Act I, Torvald lectures Nora about the moral failings of Krogstad, now Torvald's employee in his new job as a bank manager, but Torvald never articulates religiously based concerns. After the masquerade party, Torvald's best friend, Dr. Rank-who is dying of "inherited syphilis" (Mahaffey 2010, p. 70) passed on by his sexually reckless father-announces his imminent death through a calling card with a black cross over his name, but the indifferent Torvald offers no religious utterance. As Vicki Mahaffey notes, “There is something Christlike about Rank's suffering 'for another man's sins,' but Torvald's mentality is not that of Jesus" (Mahaffey 2010, p. 60). Similarly, when Torvald reads Krogstad's letter of blackmail, he does not pray about his and Nora's desperate situation. Finally, when he receives Nora's fraudulent note back from Krogstad, along with Krogstad's renunciation of his previous threats, Torvald does not thank God, despite exclaiming "I'm saved!" (188)—an exclamation that indeed might suggest the speaker's awareness of the work of a savior, especially when spoken, as it is here, on the night after Christmas. ${ }^{9}$

And tellingly, in each above situation, Torvald's absence of Christian expression contrasts sharply with his explicit preoccupation with himself. Nora and his discussion of the Christmas season early in Act I focuses on Torvald's new job as a bank manager and other economic matters. At one point, Torvald says, "Ah, it's so gratifying to know that one's gotten a safe, secure job, and with a comfortable salary. It's a great satisfaction, isn't it?" (p. 129). Remarkably, even at Christmas, he betrays no sense that his recent occupational success should be celebrated as a blessing from God. Later in the act, Torvald's expressed indignation toward Krogstad's moral failings stems from his own personal

7 The pathetic impotence of Torvald's last-ditch appeal to religion here is observed by Robert W. Haynes, who notes "Torvald's only statement regarding religion is his effort to control Nora by appealing to the conventions of her upbringing" (Haynes 2007, p. 73).

8 Unni Langås discusses a parallel between Torvald's expectations regarding religion and gender with the views of the Norwegian Hegelian philosopher and theologian Marcus Jacob Monrad (1816-1897) (Langås 2005, pp. 149-51). See also (Moi 2006, pp. 274-78), which argues that Torvald's understanding of gender articulated in this conversation reflects Hegel's generic categories for gender, categories that deny women the right to "become self-conscious, concrete individuals" (Moi 2006, p. 276).

9 We might also add that although the Helmers own a piano that Torvald adeptly plays, the only music heard during this Christmastime play is near the end of Act 2 when Torvald plays the tarantella while Nora rehearses her dance for their neighbors' masquerade party. The absence of any Christmas music is noteworthy, even as we may recognize that the music for the dance serves to advance Torvald's religion of self-exaltation, in that it helps exhibit before his friends Nora as, in Torvald's words, "a dream of loveliness"—a description of her that Torvald says was shared by "everyone [ ... ] at the party" (p. 180). 
discomfort in Krogstad's presence, not genuine ethical concerns. Torvald tells Nora, "I literally feel physically revolted when I'm around such a person" (p. 152), later admitting that Krogstad was actually "a crony of mine back in my teens" (p. 160), a fact so embarrassing to Torvald that he fires Krogstad from the bank. In Act III, Torvald describes Rank's approaching death as "ugliness" that comes between his and Nora's blissful marriage. Seemingly oblivious to the significance of the black cross on Rank's calling card, Torvald tells Nora how Rank, "with his suffering and loneliness", was "like a dark cloud setting off our sunlit happiness" (p. 186). A bit later, Torvald responds to Krogstad's blackmail with more self-love as he blames Nora: "Now you've wrecked all my happiness—ruined my whole future" (p. 187). Finally, Torvald's joyful "I'm saved!" ignores Nora, something she points out when she responds, "And I?" (p. 188). Clearly Torvald's highest devotion is to Torvald, not to the Christian religion to which he appeals. Indeed, in the words of Kristan Gjesdal, Torvald displays "a pathological solipsism, a thinking that places the individual ego in the centre of the world and deems whatever event it faces beautiful or ugly depending on whether it satisfies its own, aesthetically bolstered subjectivity" (Gjesdal 2010, p. 8). ${ }^{10}$ Ignoring Christ's costly example of painful, sacrificial love, Torvald, in his self-love, falls far short of the ideal of the self-sacrificial husband of Nora's "religion of Torvald", an ideal that better fits the Christian religion Torvald professes than the religion of self that he actually practices.

Ironically—but strangely appropriately—Nora's stated disregard for the Christian "religion" is predicated on Torvald's own self-idolatry. Indeed, we may argue that Nora's momentous decisions and actions at the end of the play are essentially determined by her changed perception of Torvald from that of a husband characterized by sacrificial love-a love she had intended to imitate to the point of her own death-to one characterized by self-centeredness, a characterization that she ironically then takes upon herself in the final portion of the drama. Significantly, after Nora informs Torvald that she had expected him to take her guilt upon himself, she tells him, "You're thinking I'd never accept such a sacrifice from you? No, of course not. But what good would my protests be against you? That was the miracle I was waiting for, in terror and in hope. And to stave that off, I would have taken my life" (p. 194). Here, Nora clearly states that she intended to match and indeed supersede Torvald's expected sacrifice with her own act of supreme selflessness, resolving to "kill herself and prevent Torvald from assuming the burden of $\sin ^{\prime \prime}$ (Northam 1965, p. 105). Although Nora's willingness to commit suicide for Torvald's sake clearly differs from Christ's self-sacrifice, her words nevertheless recall Christ's teaching, "Greater love has no one than this, that he lay down his life for his friends" (John 15:13), and, ultimately, his sacrificial death. As Johnsen writes, albeit somewhat cynically, Nora had planned to supersede Torvald's anticipated sacrifice "by taking it definitively from him with an ultimate transcendent sacrifice, redeeming his sacrifice with her own greater sacrifice" (Johnsen 2011, p. 196).

But Johnsen's implicit cynicism also suggests the problematic nature of Nora's understandings of sacrifice. Kristin Ørjasæter notes that both Nora's illegal efforts to save Torvald's life and Mrs. Linde's marriage to a man she did not love to provide financially for her family demonstrate "that sacrificing one's own happiness for the sake of other people's well being was regarded as a female duty" (Ørjasæter 2005, p. 34). ${ }^{11}$ It is against such a problematic notion of sacrifice and its attendant "gender hierarchy" that Nora rebels at the play's end (He 2008, p. 139), but her rebellion and departure are arguably based upon her responses to her other problematic understandings of sacrifice. Indeed, we also may rightly question Nora's idealistic expectation of Torvald's sacrifice, her firm belief that Torvald would for Nora's sake proclaim himself guilty of Nora's crime. For if Nora's expectation

10 Similarly, Moi considers Torvald an "aesthetically inclined egoist" (Moi 2006, p. 261).

11 Chengzhou He observes that "Helmer's story of success is actually dependent on Nora's sacrifices" (He 2008, p. 140), a matter that makes his both verbally abusive and self-centered response toward the revelation of her earlier efforts to save his life and his patronizing attitude toward Nora after Krogstad relents of his blackmail all the more problematic. Anticipating Johnsen's critique, Moi objects to Nora and Torvald's "taking themselves to be starring in various idealist scenarios of female sacrifice and male rescue" (Moi 2006, p. 257). 
on one hand suggests a husbandly love that imitates Christ's sacrifice for his church, it also exceeds the Pauline mandate for husbands. Surely a theological distinction must be made between Christ's "becom[ing] sin" for humanity's sake in order to offer himself as a substitutionary sacrifice for his church and thus rendering believers "blameless" because of his sacrifice (cf. 2 Cor 5:21 and Eph 5:27), and a husband's appropriate life-giving for his wife's sake. Many Christian theologians hold that Christ's substitutionary atonement made him "sin" in the judicial sense, taking upon himself the punishment for humanity's transgressions, but in no way ultimately suggesting that Christ performed those transgressions himself. ${ }^{12}$ Nora's expectation is that Torvald would lie to assert that he was guilty of Nora's actual crime. Nora's expectation finds no biblical mandate but effectively transgresses the ninth commandment against bearing false witness. As we have noted above, Nora affirms that to prevent such a "sacrifice" from Torvald, she "would have taken [her own] life," but her suicidal notion of sacrifice is ultimately more problematic than the above examples of female sacrifice that Ørjasæter decries, and it invites the cynical response Johnsen offers. ${ }^{13}$

Of course, misunderstandings of Christian doctrine abound in the "religion of Torvald". One might argue that Nora's misguided expectation of Torvald's taking upon himself of her guilt and her own misguided willingness to sacrifice her life for the sake of her husband's reputation are in fact Nora's misguided appropriations of the misguided doctrine of Christ's substitutionary atonement of which she must have learned during her youthful catechesis and confirmation (p. 193). Mary H. Streufert speaks for many in articulating the oft-stated concern that the image of Christ's "violent sacrifice" brings problematic "Christian images of God" and resultant destructive "practical implications for adherents' lives" (Streufert 2006, p. 113), including the notion that a proper "interpretation of Jesus' obedient self-sacrifice" mandates that a Christian woman must "sacrifice her own personal safety" by staying in an abusive marriage (Streufert 2006, p. 114). ${ }^{14}$ Perhaps Nora's willingness to sacrifice her life for Torvald's sake is her own perverse desire to imitate the "violence of the atonement" (Streufert 2006, p. 113) that Streufert and others decry.

But I instead argue that Nora's expectation for Torvald, albeit problematic, demonstrates an authentic longing for sacrificial love, a love exemplified by the Christ she does not worship, ${ }^{15}$ a love she believed was embodied by the husband who has become her god, a love she was willing to demonstrate herself. Indeed, Nora had intended to imitate Torvald's anticipated Christlike love to the greatest degree. But when Torvald fails Nora's hopes and instead demonstrates self-centeredness, Nora follows Torvald's example of self-love. Nora begins to proclaim her "duties to [her]self" to be, essentially, her "most sacred vows" (p. 193), and she abandons not only Torvald but also her children. ${ }^{16}$ Whereas Nora's previous willingness to give up her life for Torvald recalls Jesus' ultimate sacrifice of love, her departure recalls scriptural texts that portray a mother's abandonment of her children as contradicting God's faithful love for his people (Isaiah 49.15, Psalm 27.10). The consequence of

12 For one such discussion of this theme in the context of Reformed Christianity, Luther, and Calvin, see (Huggins 2013, p. 75). For an extended discussion of substitutionary atonement, including objections to it and alternative theories of atonement, see (Erickson 1986, pp. 801-23).

13 Carol Strongin Tufts argues that Nora's desire "to prevent [Torvald's] sacrifice with a more daring one of her own" demonstrates her "narcissistic affirmation of an idealized self" that, through her sacrificial death, will never face the possibility of Torvald's rejection when she gets older but "forever" remain "the perfect object of his love" (Tufts 1986, p. 156).

14 Streufert draws upon (Parker and Brock 2001, pp. 15-19), which tells the story of Anola Dole Reed, whose insistence of staying with her violent husband, who eventually murdered her, was grounded in such a belief.

15 In his Institutes of the Christian Religion, Calvin discusses at length how Christ's substitutionary atonement is motivated by God's love (Calvin 1960, 2.16.3-4 [pp. 505-7]).

16 The degree to which Nora's abandonment of her children potentially compromises her heroism has concerned various critics. In his defense of Nora, Daniel J. Brooks argues that, in the face of Torvald's implicit accusation of Nora's "moral disease" and her consequent concern about "its possible transmission to her children", Nora "feels impelled to leave, and her decision is less an act of defiance against her husband and society than an attempt to save the lives of her children" (Brooks 2013, p. 17). Thus, "her leaving is an act of love and sacrifice rather than irresponsibility and selfishness" (Brooks 2013, p. 15). Brooks' statement is another example of how prevalent various notions of "sacrifice" are within various critical discussions of Nora's character. 
Torvald's failure to meet Nora's desire for Christlike love is that Nora now follows in a truly devastating manner Torvald's own egocentric practice of the "religion of Torvald" and its characteristic self-love.

Our recognition of Nora's decision to follow the egocentric religion of Torvald—now manifesting itself in her newly declared superlative devotion to herself-will likely significantly affect our perception of Nora as the play concludes, and we do well to consider how this reading situates itself amid other interpretations of her character. Since the nineteenth century, Nora's departure has been portrayed as victorious by numerous productions and critics. In the past decade, Johnsen has argued that $A$ Doll House is truly "liberating" because it demonstrates "that Nora can walk away" and "slam the door on this wretched potlach of serial self-sacrifices" (Johnsen 2011, p. 196). And Abdur Rahman Shahin and Rizwan ul-Huq have affirmed that, because of her solitary exit, "Nora is nothing less than a hero who should be adored for such an act of bravery" (Shahin and Huq 2012, p. 294). ${ }^{17}$ By contrast, I suggest that Nora's self-focused abandonment of her family both imitates Torvald's religion of self-love and inverts the Christlike love Nora expected from Torvald. And my theologically informed reading of Nora's character differs significantly from the one offered by Mahaffey. In her article, Mahaffey offers a sustained comparison between Nora and Christ, arguing for "a fundamental rereading of Christian doctrine" that suggests, in light of the glorious bodily "transformation" and "transfiguration" of the resurrection, that "Jesus' sacrifice" of the crucifixion "is not selfless; it is instead a model for the changing of the self, for facilitating its evolution [ ... ] the crucifixion and the resurrection show that Jesus was modeling a program of metamorphosis" (Mahaffey 2010, pp. 69, $62,69)$. Mahaffey writes that "Nora's dancing is her Passion, her agony and ecstasy", and that her departure marks her "personal resurrection, which will not come without sacrifice (she will leave her children, at least temporarily), but what she will no longer sacrifice is her own potential for growth" (Mahaffey 2010, pp. 63, 68). But Mahaffey's reading of Jesus' crucifixion and resurrection cannot justify Nora's self-focused destruction of her family, and Mahaffey's implicit suggestion that Nora can both continue her pursuit of such self-focused "growth" and perhaps even reunite with her children frankly ignores the legal and social realities of divorce and child custody in Nora and Torvald's contemporary situation. ${ }^{18}$ By contrast, I contend that Nora follows Torvald into both his spiritually disastrous self-love and what Gjesdal calls Torvald's "illusion of being absolutely autonomous and self-sufficient and the idea that such autonomy and self-sufficiency is a necessary condition for a free and beautiful existence" (Gjesdal 2010, p. 11).

My view that Nora has embraced such self-love and delusionary autonomy also resists the overly optimistic reading of Kristin Ørjasæter, who asserts that Nora's leaving Torvald "initializes the necessary process which eventually might make them both develop into free human beings fit for a true loving union with an equally free partner" (Ørjasæter 2005, p. 32). Nora's exit does not lend itself to the kind of relational negotiation that would enable her and Torvald to reunite in the manner Ørjasæter postulates. Rather, as Joel Shatzky and Sedwitz Dumont plausibly contend, "the uncompromising

17 We should note, in fairness, that many critics since the play's first production to the present have criticized Nora. In the words of Joan Templeton, writing more than thirty years ago, "for over a hundred years, Nora has been under direct siege as exhibiting the most perfidious characteristics of her sex" (Templeton 1989, p. 28). Particularly memorable criticisms have been offered by June Schluter, who, having suggested that "Nora is deceitful and manipulative from the start", writes that Nora's departure "reflects only a petulant woman's irresponsibility" (Schluter 1985, pp. 64-65); and by Tufts, who argues that, throughout the play, Nora displays the diagnosable criteria of a narcissistic personality (Tufts 1986).

18 Moi notes that "the law of [Nora's] day made it impossible for a woman who left her home to keep her children" (Moi 2006, p. 278). See (Melby et al. 2000), which observes that even after Norway's 1888 "property acts", passed to afford married women a greater legal standing, husbands maintained "the entire disposal over [a couple's] joint property and had legal custody of the children" (Melby et al. 2000, p. 14). Hanne Marie Johansen notes that until 1909, the Lutheran divorce rules from the Ordinance of 1582 "remained the valid divorce law", with spousal desertion being treated "as adultery" (Johansen 2018, p. 42). Moreover, "Equality in marriage was not established until 1927 when a statute on property relationships between spouses made the wife a partner with equal rights and responsibilities" (Heffermehl 1972, p. 631). Admittedly, my approach also differs from Nora and Torvald's "contemporary situation" by reading the play's themes through Reformed Christianity rather than contemporary Lutheran sources, but in any case it is anachronistic to suggest that the deserting Nora might be reunited with her children without returning submissively to Torvald. 
idealism that leads Nora to abandon her children" demonstrates Ibsen's desire that "his audience" would "weigh the consequences of holding to an idealistic view above everything else, the 'all or nothing' mentality that would result in the horrors of idealistic, uncompromising absolutism that is even now a threat to humanity" (Shatzky and Dumont 1994, p. 83). ${ }^{19}$ Significantly, Moi, who affirms Nora's departure, calls Torvald "a card-carrying idealist aesthete if there ever was one" and critiques "Nora's unthinking echoing of" his "idealism" (Moi 2006, p. 257). Moi implies that Nora's departure is her breaking free from such idealism (Moi 2006, pp. 274-78), whereas I argue that her departure is another manifestation of such problematic idealism, which disregards the complexity and fragility of human beings and their relationships in favor of an all-encompassing and unattainable ideal. Although Moi rightly decries aesthetic forms of problematic idealism, she affirms on her concluding page that "[a]s long as marriage and motherhood are incompatible with women's existence as individuals and citizens, Nora will have none of them" (Moi 2006, p. 278). Moi's statement recalls "the 'all or nothing' mentality" of the "uncompromising idealism" that Shatzky and Dumont warn against.

Although she does not engage Shatzky and Dumont's objections to Nora's departure, Moi briefly references their article in an endnote, simply and perhaps dismissively writing that they "reduc[e] idealism to a moral and political position" (Moi 2006, p. 279, n. 3). But Moi herself asserts that "idealist aesthetics" also "seamlessly merge aesthetics and ethics (Moi 2006, pp. 256-57), a merging exemplified in Torvald's "sense of beauty," which "admits no separation between ethics and aesthetics (Moi 2006, p. 262). And the Reformed theological critique of the "religion of Torvald" I have discussed throughout this essay prompts new questions. Indeed, I put forward that the well-founded moral concerns that inspire Moi's objections to Torvald's intolerant, aesthetically and ethically idealistic mistreatment of Krogstad and Nora (Moi 2006, pp. 262-63, cf. p. 274) should also extend further and inspire objections to Nora's idealistic abandonment of her young children. Remarkably, we may recognize that both Moi's regarding Torvald as a "brutish" and "petty-minded" "aesthetically inclined egoist" (Moi 2006, p. 261) and Gjesdal's aforementioned description of Torvald's "aesthetically" based "pathological solipsism" (Gjesdal 2010, p. 8) testify to the horrors of the self-focused "religion of Torvald". Moreover, I assert that Nora's idealistic "all or nothing" decision to abandon her family in favor of her "duties to [her]self" demonstrates her following Torvald's example of "pathological solipsism" as she now embraces his solipsistic "religion of Torvald". ${ }^{20}$

Similar to Shatzky and Dumont, I argue that idealistic or heroic interpretations of Nora's severance from Torvald are far too simple, for they reject one harmful paradigm only to embrace another. Indeed, if we are inclined to view Nora's departure from her husband as the triumph of a newly autonomous woman, we might more accurately reconsider Nora as a woman who, however physically separated from Torvald, now, at the play's conclusion, ironically and disturbingly imitates him-and his "religion"-more fully than ever before.

Funding: This research received no external funding.

Acknowledgments: Preliminary work on this essay was done some years ago during a sabbatical leave. It was developed into its present form with the benefit of a course release afforded by a Calvin Research Fellowship. I deeply thank Calvin University for its support. I also thank Charles Gillespie, Larry Bouchard, Brian Ingraffia, and the two anonymous readers for Religions for their helpful comments and suggestions on earlier drafts of this essay. Finally, I thank my former Calvin student Joel Moyer for first pointing out to me how Jesus' incarnation and death gives the lie to Torvald's claim that "there's no one gives up honor for love."

Conflicts of Interest: The author declares no conflict of interest.

19 Shatzky and Dumont support their contention by noting that Ibsen's subsequent "social plays"—Ghosts, An Enemy of the People, and The Wild Duck, as well as Hedda Gabbler-each also warn against such "uncompromising idealism" (Shatzky and Dumont 1994, p. 83).

20 The notion that Nora follows Torvald into "pathological solipsism" coincides well with Tufts' assertion that Nora's exit demonstrates her "new narcissistic self-image" (Tufts 1986, p. 157). 


\section{References}

Beyt, Adam. 2019. 'Beautiful and New': The Logic of Complementarity in Hedwig and the Angry Inch. Religions 10: 620. [CrossRef]

Bible, Holy. 1984. New International Version. Colorado Springs: International Bible Society.

Brooks, Daniel J. 2013. Infection: The Motivating Factor behind Nora's Flight in A Doll House. The Explicator 71: 14-17. [CrossRef]

Calvin, John. 1960. Institutes of the Christian Religion. Edited by John T. McNeill. Translated by Ford Lewis Battles. Philadelphia: The Westminster Press, vol. 1.

Erickson, Millard J. 1986. Christian Theology. Grand Rapids: Baker.

Gjesdal, Kristin. 2010. Self-Knowledge and Aesthetic Consciousness in Ibsen and Hegel. In Acta Ibseniana VII: Ibsen and the Modern Self. Edited by Kwok-kan Tam, Terry Siu-han Yip and Frode Helland. Hong Kong: Open University of Hong Kong Press, pp. 1-16.

Hastie, W. 1890. Translator's Preface. In Christmas Eve: A Dialogue on the Celebration of Christmas. Edited by Friedrich Schleiermacher. Translated by W. Hastie. Edinburgh: T \& T Clark, pp. v-xv.

Haynes, Robert W. 2007. Betrayal and Responsibility in Henrik Ibsen's A Doll's House and Little Eyolf and Horton Foote's The Young Man from Atlanta. Baylor Journal of Theatre and Performance 4: 71-82.

He, Chengzhou. 2008. Ibsen's Men in Trouble: Masculinity and Norwegian Modernity. Ibsen Studies 8: 134-49. [CrossRef]

Heffermehl, Karin Bruzelius. 1972. The Status of Women in Norway. The American Journal of Comparative Law 20: 630-46. [CrossRef]

Huggins, Jonathan R. 2013. Living Justification: A Historical-Theology Study of the Reformed Doctrine of Justification in the Writings of John Calvin, Jonathan Edwards, and N.T. Wright. Eugene: Wipf \& Stock.

Ibsen, Henrik. 1978. A Doll House. In The Complete Major Prose Plays. Translated by Rolf Fjelde. New York: Farrar, pp. 123-96.

Johansen, Hanne Marie. 2018. The History of Divorce Politics in Norway: Continuity and Change. Scandinavian Journal of History 43: 40-63. [CrossRef]

Johnsen, William A. 2011. Modern Sacrifice. Religion and Literature 43: 194-200.

Langås, Unni. 2005. What Did Nora Do? Thinking Gender with A Doll's House. Ibsen Studies 5: 148-71. [CrossRef]

Lavender, Joshua. 2008. Seeking the Greatest Miracle: Psychological Mythology in Ibsen's A Doll House. The Corinthian 9: 119-27.

Mahaffey, Vicki. 2010. Portal to Forgiveness: A Tribute to Ibsen's Nora. South Central Review 27: 54-73.

Melby, Kari, Anu Pylkkänen, Bente Rosenbeck, and Christina Carlsson Wetterberg. 2000. Introduction. In The Nordic Model of Marriage and the Welfare State. Edited by Kari Melby, Anu Pylkkänen, Bente Rosenbeck and Christina Carlsson Wetterberg. Copenhagen: Nordic Council of Ministers, pp. 13-26.

Moi, Toril. 2006. First and Foremost a Human Being: Idealism, Theatre, and Gender in A Doll's House. Modern Drama 49: 256-84.

Northam, John. 1965. Ibsen's Search for the Hero. In Ibsen: A Collection of Critical Essays. Edited by Rolf Fjelde. Englewood Cliffs: Spectrum/Prentice Hall, pp. 91-108.

Ørjasæter, Kristin. 2005. Mother, Wife, and Role Model: A Contextual Perspective on Feminism and A Doll's House. Ibsen Studies 5: 19-47. [CrossRef]

Parker, Rebecca Ann, and Rita Nakashima Brock. 2001. Proverbs of Ashes: Violence, Redemptive Suffering, and the Search for What Saves Us. Boston: Beacon Press.

Schleiermacher, Friedrich. 1890. Christmas Eve: A Dialogue on the Celebration of Christmas. Translated by W. Hastie. Edinburgh: T \& T Clark.

Schluter, June. 1985. How to Get into A Doll House: Ibsen's Play as an Introduction to Drama. In Approaches to Teaching Ibsen's "A Doll House". New York: Modern Language Association, pp. 63-68.

Shafer, Yvonne. 1985. Complexity and Ambiguity in Ibsen's A Doll House. Literature in Performance: A Journal of Literary and Performing Art 5: 27-35. [CrossRef]

Shahin, Abdur Rahman, and Rizwan-ul Huq. 2012. The Identity In-Between: The Enquiry of Apathy and Existential Anguish in Henrik Ibsen's A Doll House. Language in India 12: 287-97.

Shatzky, Joel, and Sedwitz Dumont. 1994. 'All or Nothing': Idealism in A Doll House. Edda 1: 73-84. 
Sprinchorn, Evert. 1980. Ibsen and the Actors. In Ibsen and the Theatre. Edited by Errol Durbach. New York: New York University Press, pp. 118-30.

Streufert, Mary J. 2006. Reclaiming Schleiermacher for Twenty-First Century Atonement Theory: The Human and the Divine in Feminist Christology. Feminist Theology 15: 98-120. [CrossRef]

Templeton, Joan. 1989. The Doll House Backlash: Criticism, Feminism, and Ibsen. PMLA 104: 28-40. [CrossRef]

Tufts, Carol Strongin. 1986. Recasting A Doll House: Narcissism as Character Motivation in Ibsen's Play. Comparative Drama 20: 140-59. [CrossRef]

(c)

(C) 2020 by the author. Licensee MDPI, Basel, Switzerland. This article is an open access article distributed under the terms and conditions of the Creative Commons Attribution (CC BY) license (http://creativecommons.org/licenses/by/4.0/). 
Article

\title{
Religion and the Limits of Metatheatre in Our Town and Sunday in the Park with George
}

\author{
Larry D. Bouchard
}

Department of Religious Studies, University of Virginia, Charlottesville, VA 22904, USA; ldb4k@virginia.edu

Received: 31 December 2019; Accepted: 10 February 2020; Published: 18 February 2020

\begin{abstract}
This essay explores theatrical drama alongside aspects of religious dimensionality David Tracy analyzes in terms of limit experience, limit language, and limit questions. The claim is that metatheatrical forms can correlate with limit dimensions, a correlation which may prove as pertinent as ritual for linking drama with religious experience, thought, and practice. Here, metatheatre and limit dimensions are further defined in respect to Thornton Wilder's 1938 play, Our Town, and Stephen Sondheim and James Lapine's 1984 musical, Sunday in the Park with George. The essay identifies distinct though often overlapping forms of metatheatre: plays or performances that (1) explicitly refer to themselves, or (2) represent theatrical or theatre-like works within their stories and expressed worlds (e.g., plays within plays), or (3) dramatize theatre-like and performative aspects of ordinary life. Just as Wilder foregrounds metatheatrical relations to create an impression of the eternal, Sondheim and his collaborators reflect on their work's ontological conditions of possibility by bringing to life another work, a painting, at distantly separated moments in time. Our Town and Sunday in the Park invite us to enter social and ritualized spaces inhabited by commonplace yet archetypal persons; they culminate in moments where the audience is to discern past, present, and future in simultaneous proximity; and with their different contents and forms, they prove good plays for elaborating relations among theatre, limit experience, and religious dimensionality.
\end{abstract}

Keywords: metatheatre; limit experience; religious dimensionality; Wilder; Sondheim; Lapine

In this wedding I play the minister. That gives me the right to say a few more things about it.

For a while now, the play gets pretty serious. [. . .]

And don't forget all the other witnesses at this wedding, - - the ancestors. Millions of them.

-Stage Manager to audience, Our Town

(Indicates painting)

But this is our family tree.

Just wait till we're there and you'll see-

-Marie to Elaine, Sunday in the Park with George ${ }^{1}$

\section{Introduction}

Theatrical drama is a hybrid genre of live performance before a live audience and a story or script composed with the aim of enactment. A feature of theatrical drama that may prove pertinent to religious experience is metatheatre. Notice, in the first epigraph, how the Stage Manager speaks to us,

1 Wilder 1957; Sondheim and Lapine 1986; future page citations parenthetical. As both plays employ ellipses (...), my ellipses in all quotations are bracketed [. . .]. 
the audience, about the play in which he also performs various minor characters-here, a minister at a wedding. Since we are also witnesses at this wedding, there is a sense in which we are among the "ancestors," and so the significance of our role in this wedding is enlarged pretty seriously. Metatheatrical relations in the second passage are more complex. The elderly Marie gestures to a large painting in Act II, which defined the social world of Act I, a century before. She claims to have been "in" the painting as an infant, and now she plans to visit what remains of its world, her ancestors, in Paris. Although addressing Elaine, her "you'll see" addresses us as well. Seeing, as perception and involved discernment, is crucial to the theatrical forms and revelations of both plays.

This essay explores drama and metatheatre alongside aspects of religious dimensionality David Tracy analyzes in terms of limit experience, limit language, and limit questions. ${ }^{2}$ My claim for theatrical drama will be that metatheatrical forms can correlate with 'limit dimensions,' a correlation that may prove as pertinent as ritual for linking drama with religious experience, thought, and practice. ${ }^{3}$ Metatheatre, or theatre reflecting itself as theatre, entered the critical vocabulary with Lionel Abel (1963) in reference to what he termed metaplays, especially by Shakespeare, Calderon, and the modernist Luigi Pirandello. ${ }^{4}$ While Abel was at pains to distinguish metatheatre from an Aristotelian view of tragic realism, I find it difficult to locate theatrical drama in any period that is not at least implicitly meta. Metatheatre also jibes with but predates modern self-reference and postmodern intertextuality, with which it is often conflated. ${ }^{5}$ Play, audience, and players are always there together, generating reflexive references.

Here, I further define and nuance metatheatre and limit dimensions in respect to Thornton Wilder's 1938 play and Stephen Sondheim and James Lapine's 1984 musical. Just as Wilder consternated American drama by banishing naturalist staging and foregrounding metatheatrical relations, Sondheim and his collaborators "reinvented" the American musical. ${ }^{6}$ The analogy is complicated, however, in that musicals have always foregrounded metatheatre through their 'numbers' — that is, their featured songs which address the audience as much as the characters in the story. Sondheim takes the integrated musical (a fusion of song with plot and character) and makes it self-reflective of its own existential realism ${ }^{7}$ and, I would add, idealism, much as does Wilder's metatheatre. In particular, in Our Town and Sunday in the Park with George we enter social spaces inhabited by commonplace yet archetypal persons. Both plays culminate in moments where the audience is to discern past and present in simultaneous proximity to something like eternity. Thus, despite their different contents and forms, these are good plays for elaborating relations among metatheatre, limit experience, and religious dimensionality. If Our Town is a paradigm case for these relations, it may be that Sunday in the Park serves as a 'limit case' or, better, a 'case of limits.'

\section{Limit Experience and Metatheatre 1, 2, 3}

Metatheatre, in plays as written and as performed, is a matter of encountering limits and crossing boundaries. So metatheatre lends itself, prima facie, to limit dimensions in experiences construed as

2 Tracy 1975, pp. 92-103.

3 A central issue in religion and arts is how a work with specific genre traits-a lyric poem, painting, novel, sculpture, oratorio-generates effects (aesthetic, affective, semantic) through its form (actually a hybrid of forms) at intersections with religion. Elsewhere I sketch approaches to religion and art to keep 'in play' — phenomenological, hermeneutical, historical, and deconstructive - in my "Religion and Literature: Four Theses and More" (Bouchard 2009). The present essay elaborates my suggestion that metatheatre can link drama to religion via limit questions, such as "Why theatre?" or "Why humanity?" in "Dramatic Ways of Being Religious" (Bouchard 2014).

4 Abel 1963, 2003.

5 See Konkle, 2018, on Our Town and The Skin of Our Teeth "as Proto-Postmodern Drama." He cites Mudasir 2011: "[P]ostmodern drama foregrounds the notion of 'self-reflexive referentiality'" (nearly a definition of metatheatre).

6 McLaughlin 2016.

7 McLaughlin understands Sondheim musicals to be contextualized by postmodernism (p. 27), with Sunday in the Park also reclaiming the realism of how artifice can capture "the dynamic, fluid chaotic world" (p. 167). 
religious, spiritual, moral, sacred, numinous, mysterious, and the like. Tracy does not define religion as limit but notices that where we find religion, howsoever defined, we tend to find limit phenomena.

Easiest to visualize are limit questions, which ask about conditions for the possibility of the domain from which the question arises. For instance, "Why physics?" can be asked within physics if the why seeks a causal (physical-mathematical) explanation. Yet "Why physics?" asks about the conditions for the possibility of physical causation itself; it is a question about the very meaning of physics and thus points beyond its limit or horizon. Diagram physics as a circle, and the question can be an arrow starting from within physics and arcing over the limit into an undefined area. Queries like "Why chemistry?" point to physics, the limit-of chemistry, for their terms are congruent. Whereas "Why physics?" would require different language altogether (philosophical, mythical, poetic). Tracy takes up another question, "Why morality" or "Why be ethical?" Again, the terms come from ethics, so the question is not meaningless in its domain, yet its arrow points 'beyond' ethical discourse. "[W]e cannot really produce a moral argument for being moral." 8

For Tracy, two sorts of experiences go with limit questions. We can construe "limit-to" as encountering a given domain's horizon from within. It is a felt as well as logical limit; "why keep promises?" pushes us up to a sense of morality's edge. Yet "limit-of" experiences infer an "other side' of the limit, now felt as a horizon opening into ontological uncertainty. Logically odd forms of language often accompany religious limit-of experiences: symbol, metaphor, myth, prophecy, mysticism, articulating beliefs or practices purporting to 'answer' limit-to questions. In Christianity, grace (limit-of) transforms situations of sin and finitude (limit-to). In Hinduism, moksha (experienced as limit-of) releases one from the karmic cycle of births and deaths, samsara (limit-to). By itself, however, the logic of limit does not necessitate that limit-of experiences be liberating, transformative, or trust filling. A symbolism 'beyond the limit' might bode nemesis, chaos, threat, tragic fate, and undermine 'basic trust' in reality. ${ }^{9}$

Metatheatre's 'limits' need not be religious or mysterious and rarely make us ponder 'conditions for the possibility' of theatre. Metatheatre wants to delight and intrigue. But its analogy to limit experience is in the play-within-a-play structure. Since the outer play frames the inner play, it is like the limit-of area beyond the inner play. The world of Hamlet frames "The Murder of Gonzago," or "Mousetrap." The world of Our Town frames George and Emily's wedding. Sunday in the Park with George is more complex. From one angle, the Chromolume device in Act II, an electronic light sculpture, is limit-of for the pointillist painting from Act I, simply because the Chromolume 'refers' to (projects images or impressions from) Georges Seurat's A Sunday Afternoon on the Island of La Grande Jatte. From another angle, it is the painting-source of Act I's characters-that frames Sunday in the Park. The musical is figuratively a play within a painting, which is literally a painting within this play. ${ }^{10}$ Yet metatheatre is not always a play within a play. When the Stage Manager tells us about Our Town, we become the frame of this play, indicative of its 'beyond,' and participate-more than audiences usually do-in its limit-of dimension. The "our" of the title, like the "in" and "with" of Sunday in the Park with George, signals our being incorporated into these worlds while remaining at a distance from them, at their limits.

It may well be that all theatrical drama is implicitly metatheatrical. Theatre demarcates and crosses differences between show and non-show, appearance and reality, script and performance,

8 Tracy 1975, p. 102; his analyses of limit credit philosopher Stephen Toulmin on the issue.

9 On Tracy and limit-of, see Shapiro 1983, pp. 6-7. On the tragic vision: see Ricoeur 1967, pp. 211-31. For Victor Turner in "Betwixt and Between," Turner 1967, liminality in rituals and social dramas can involve dangerous passages across limits, passages often framed by religious or quasi-religious lore. See his also his analysis of 'social dramas' and the story of Thomas Becket (Turner 1974, pp. 60-97).

10 The play also recapitulates meta aspects of the painting. On the $10^{\prime} \times 6.5^{\prime}$ painting itself, see Herbert and Harris 2004 , cited further below. McLaughlin 2016, p. 154, observes that as the play begins, it shows that Seurat, the figures he composes, and "the audience, are always both inside and outside the painting." 
stage spaces and other spaces, show time and other times, ${ }^{11}$ persons playing persons and persons playing roles. Nevertheless, metatheatre becomes a more distinctive feature when it intensifies our awareness of such crossings and stimulates thought and feeling. I have found it useful to distinguish three overlapping sorts of metatheatre:

Metatheatre-1 (MT-1) comprises times when a play or performance more-or-less explicitly refers to itself, as with Wilder's Stage Manager and Vivian in Margaret Edson's Wit. Shakespeare's soliloquies and asides play as MT-1, inviting us into the play or into a character's (or actor's) 'theatre of the mind.' Brecht's alienation effects and placards can be MT-1 in Galileo ("You will not resent, we hope, The truth about his telescope"12); so too the numbers or songs in musicals. MT-1 ('breaking the fourth wall,' though all metatheatre does that) makes apparent the limit or edge of the play's 'world.' The audience is made distant yet close to this edge; in effect, we become part of the play's limit-of. ${ }^{13}$ Sometimes, a play's edge draws attention to limits and horizons of our worlds-or such reflecting may happen simply as a matter of course.

Metatheatre-2 includes other edges: performances within performances, the outer becoming limit-of for the inner. Plays-within inevitably mirror the framing play and, again, can evoke questions about limit dimensions in our worlds-as with Hamlet. In staging Mousetrap, Hamlet is testing both his uncle's moral guilt (limit-to) and the nature of the Ghost ("spirit of health or goblin damned"-limit-of). In Suzan-Lori Park's Venus, the exhibitions (theatrical and 'scientific') of Saartjie Baartman also fit MT-2. So may performances other than theatrical in a story: thus Nora's dancing the Tarantella to distract her husband in Ibsen's Doll's House. Trial scenes can be MT-2, such as the mock trial in Lear. The sheep deception in the medieval Second Shepherds' Play looks like MT-2. So does Dionysus in Euripides' Bacchae, when he tells us he is a god impersonating a mortal; we are in MT-1 and near MT-2.

Metatheatre-3 is less straightforward. It draws attention to theatrical and performative dimensions of ordinary life, where "life is a dream" (Calderon) or "all the world's a stage" (Shakespeare). The world stage includes 'parts we play' and social or vocational roles, often overlapping and hybridized, with codes and ideologies. ${ }^{14}$ Every role, action, and reception implies a temporal-social-cultural world of limits and horizons, surpassable and unsurpassable. ${ }^{15}$ MT-3 also spotlights performative action: 'effective' speech and gestures such as promising, confessing, embracing, performed for others to interact with or witness. ${ }^{16}$ MT-3 stages the performance metaphors so frequently applied to ordinary life. While social dramas (Turner) can be represented by plays within, MT-2, they may figure as MT-3, where persons improvise parts in political conflict, as in T. S. Eliot's Murder in the Cathedral and Wole Soyinka's Death and the King's Horseman.

Since we all inhabit potentially conflicted roles, with more integrity or less; and since drama purports to represent us all; and since theatre and performance are 'in' the worlds drama mirrors, ${ }^{17}$ then with MT-3 we see the convergence of metatheatre with the theatrical generally. To be sure, this third category is vaguer. Perhaps to qualify as metatheatre, theatre-like moments from life must be made noticeable in the plot or text. Yet distinguishing 1,2, and 3 is not the point. The point is that the

11 See Gillespie 2019, on "showtime," referring to running time and time as experienced in a play/performance's world. Our Town ends at "Eleven o'clock in Grover's Corners," just when an eight o'clock three-act show would end.

12 Galileo, Brecht 1966, p. 55.

13 In his appreciation of Calderon's metatheatrical allegorical play, The Great Theatre of the World (1635), Hans Urs Von Balthasar 1988, pp. 19-20, 163-66, observes that God occupies all niches of the theatrical limit-of: author, director, audience (and in Christ the decisive, though invisible actor).

14 On performative selves, see Goffman 1959; Butler 1990; and also Bakhtin 1981, on hybridized social speech in the novel.

15 On theatre expressing pluralistic 'worlds,' see Quigley 1985. Of Yeats' play, The Countess Cathleen, Quigley writes, “The sense of remoteness and distance is one that is registered by the implied universality of the world motif. [. . .] We are invited to stand with Cathleen inside her world and contemplate from within the notion of its distant and remote horizons" (p. 9).

16 J. L. Austin's How to Do Things with Words (Austin 1962) is a text usually in the background of discussions of performativity.

17 On theatrical drama mirroring itself, see what Driver 1970, calls “theatrical positivism," pp. 348, 375-76. 
limits-to and limits-of personal and communal existence are disclosed and explored, delightfully and critically, 'at' and 'in' and 'through' the limits of theatrical drama. ${ }^{18}$

\section{Our Town and Our Towns}

The religious premises of Our Town are well known. In Act III, the Stage Manager asserts an alternative, interim temporality: the dead are "weaned" from finite attachments (confronting limit-to) to prepare for "something important," for "the eternal part in them to come out clear" (awaiting limit-of). Rather than sins being purged as in Dante's Purgatorio, it is life concerns, relations, ambitions, memories-and "your identity Mrs. Smith?" (p. 82). Identity is a radical thing to lose, but even in Paradiso mystical union with divine grace entails some relaxation from fraught earthly identity. Wilder's weaning temporality has its logic: before we can move on, we need release from what holds us back, especially if moving on entails a new discernment. Our Town is an intricately constructed play nearly ruined by jillions of cozy productions and the impression that a pale New England provincialism proposes Wilder's normative view of American society. ${ }^{19}$ To remain compelling, the play must show sources of disclosure and must apply levers of critique. My aim is to indicate where its forms of metatheatre and its religious premises intersect, seen in productions that resist the liabilities of nostalgia.

Behind a number of recent, edgy Our Towns is a Lincoln Center production of 1988, directed by Gregory Mosher (later broadcast on PBS, where I saw it) and remembered for Spalding Gray as the Stage Manager. The whole cast was stunning, particularly Eric Stoltz as George Gibbs and Penelope Ann Miller as Emily Webb, and it has been my reference point for the play. The staging was minimal as per the script, with period costumes except for Gray, who wore ordinary street clothes and spoke pointedly, without wizened crustiness. Detractors such as Frank Rich found him insufferable: Our Town can be dark but not that dark. Mel Gussow countered that though realistically dark, the show was not cynically dark. ${ }^{20}$ In my view, Gussow and Gray got it right. The cast resisted nostalgia to find aching ambiguity amid the compressed simplicities of home, society, and New Englandish intonations.

Today, good productions of Our Town are likely to look and sound like our towns, with vocal, social, racial, and gender inclusivity. In 2017, Deaf West doubled the roles with signing and speaking actors to convey the usual point that even in a "multicultural utopia," ${ }^{21}$ we should cherish every moment. I regret not seeing it, nor a startling production directed by David Cromer, which originated with Chicago's Hypocrites company. Cromer sometimes played the Stage Manager. He spoke as if 'out of character,' in the hurried but casual cadences of an office manager- "showing the new employees where the water cooler and bathrooms are"-in stage space closely crowding audience

18 My order of enumeration is merely convenient, from direct theatrical self-reflexivity to more indirect. If inspired by Paul Ricoeur's "threefold mimesis," I do not follow his order. It is possible my MT-3 corresponds to his mimesis-1, where human life always has a narrative quality that anticipates representation. My MT-1 (plays or performances that explicitly interpret themselves to audiences) may go with Ricoeur's mimesis-3, where we consciously interpret life in terms of narrative. Mimesis-2 is the narrative representation of life, as in fiction or history; it could include plays representing the performance of other plays, MT-2. See Ricoeur 1983, chp. 3.

19 Richard Goldstone's biography, 1975, pp. 140-43, treats Wilder's play as a normative celebration. Whereas I see its universals of value-in-the-mundane, associated with liberal America, serving as engines of critical resistance, here and in The Skin of Our Teeth (1942). Penelope Niven's Thornton Wilder: A Life (Niven 2012) gives a nuanced account of Our Town's making: he wrote Act III near Zurich (p. 442), while watching Europe and the world "rush into an abyss" (his words, p. 420). She finds a remarkable "amalgam of sources" immediate to the imagining of the play: "Ibsen and Nestroy, Dante and Molière, Gertrude Stein and Alfred North Whitehead" along with "Goethe, Balzac, and Nietzsche" (p. 426). Lincoln Konkle 2006, pp. 131-49, situates the play's idealized past and fraught historical present in the tradition of Puritan sermons and jeremiads.

20 Rich 1988; Gussow 1988. To be fair, Rich was decidedly mixed, praising the cast except for Gray, whom he thought incongruously repeated tones from his monologue and $1987 \mathrm{film}$, Swimming to Cambodia. But I find no "snide cynicism" in the 1989 PBS video, re-directed for television by Kirk Browning. Gussow noted that Gray "carefully avoids anything that might be misinterpreted as charm. At the same time, he is not dispassionate. He is, instead, realistic, as he explores the small pleasures and defeats in 'Our Town.'”

21 McNulty 2017, review of Deaf West's production of Our Town at the Pasadena Playhouse, Sheryl Kaller director (accessed 12 July 2019). 
space, the houselights always up; when Helen Hunt took over the part, she relished the incongruity of being called "Sir." 22 A danger in such universalizing approaches is that by eliminating $1901 \mathrm{New}$ England rural particularity, the universals may sound thin. Cromer countered with a chilling coup de théatre most reviewers at the time hesitated to spoil. In the third act, when Emily visits her past, the players donned turn-of-the-century attire. Then, more players than in the speaking cast brought in chairs to make for an uncomfortably packed graveyard. The audience found itself sitting among the uncounted dead. ${ }^{23}$

In what follows, I often have the 1988 show in mind, along with other productions. Since the Stage Manager's soliloquies are models for metatheatre-1, they may obscure -2 and -3 in the play; so, I will reverse the order here.

\subsection{Metatheatre-3}

In Our Town, metatheatre-3 provides a living performative background for rituals (metatheatre-2) like the wedding and funeral. By performative background, I mean social roles and parts routinely played (e.g., lover, soldier, physician, parent); effective speech and gestures (promising, giving); and audience-like, distanced witnessing of others' performances. On the morning of the wedding, Act II, Dr. and Mrs. Gibbs (Frank and Julia) are at breakfast, itself loosely a ritual. He mentions another ritual, having overheard George shaving and practicing " II do' to the mirror, but it don't sound too convincing to me" (p. 51). Frank then recalls their own wedding: "There I was in the Congregational Church marryin' a total stranger." His liminal fear back then was loss of words after a few weeks of conversation.

I was afraid we'd run out and eat our meals in silence, that's a fact. Well, you and I have been conversing for twenty years now without any noticeable barren spells.

MRS. GIBBS: Well,-good weather, bad weather-'tain't very choice, but I always find something to say. (p. 53)

Not only are the Gibbs describing ritual, they are critics of their performance. Catherine Bell argues that ritual's effectiveness depends on keeping its arbitrary, power-aggrandizing nature hidden, and Stephen Greenblatt believes staging ritual in theatre "empties" it of power by exposing its artifice. ${ }^{24}$ The Gibbs seem to register such worries—were the dialogue by Beckett, it might evoke absurdity—yet also refute them. Their ironizing routine talk at breakfast (artificial, different-yet-the-same) enlarges their and our sense of this breakfast ritual's import.

The Stage Manager then takes us back to the day the romance began. After arguing and reconciling at the drugstore soda fountain, where George decides not to go to agricultural school but farm in Grover's Corners and "improve" his character, George says to Emily, "So I guess this is an important talk we've been having" (p. 69). His statement observes their conversation like an audience, from a retrospective distance. The effect of this distance is to heighten their awareness of the talk's significance, a heightening the whole play attempts for its audience. ${ }^{25}$ To forgo college and school-smart independence to marry locally indicates the weight of social scripts. Played one way, it creates nostalgia; played differently, it could signal in Wilder a bourgeois complacency. ${ }^{26}$ Played yet another direction, the stereotypes are part of a critique that still honors simplicity. Wilder wrote Our Town with European democracy on the brink. By 1938, its pre-automobile, pre-radio, pre-women's

22 See Isherwood 2009, review of Our Town, Barrow St. Theatre production, David Cromer director; Patrick Healy 2010, reviewing Cromer's production now with Helen Hunt in the part of Stage Manager.

23 Shirley 2012, review of Our Town (with Hunt), at the Broad Stage in Pasadena, CA (accessed 12 July 2019 ).

24 Bell 1992, pp. 206-7; Greenblatt 1998, p. 126.

25 See Von Balthasar 1988, p. 83, on Wilder's "telescopic camera."

26 States 1985, pp. 97-99; Driver 1970, pp. 339-40. 
suffrage, pre-war, pre-Depression time was already a fading myth, imagined in an isolated 'corner' of New Hampshire. ${ }^{27}$ While Wilder shows via this mythos the unrecognized yet super-abundant value of ordinary moments—-within "the Universe, the Mind of God" (p. 45)—there are also critical impulses that good productions find.

Critique is noticeable in the portrayal of church choir director, organist, and suicide Simon Stimson. None will state what finally destroys him, other than alcohol. "Well, he's seen a peck of trouble, one thing after another..." trails off Mr. Webb, editor of the paper (p. 43). Was Simon gay and beside himself in marriage, depressive, trapped in debt, desperately bored, traumatized by culture? ${ }^{28}$ Indeed, 'culture' is another critique in Our Town. From the audience someone asks, "Is there no one in town aware of social injustice and industrial inequality?" And another, "Mr. Webb, is there any culture or love of beauty in Grover's Corners?" "Well, ma'am there ain't much-not in the sense that you mean." People attend to seasons, sunrises, and birds. They like Robinson Crusoe, the Bible, Handel, and Whistler's "Mother" (pp. 24,25). The Mind of (nature's) God and the blessed "ties that bind" encompass these matters of culture, history, and natural beauty. Yet the play knows our experience of this Mind to be ambiguous, as much of anguish as delight when trying to fathom life and death in its context. (The Stage Manager interrupts to say that paperboy Joe Crowell will study engineering and then die fighting in France, "All that education for nothing," p. 10).

\subsection{Metatheatre-2}

Our Town's ceremonies and rituals fit metatheatre-2 (plays within plays). There is the wedding, a choir rehearsal, and a hymn sung at Emily's funeral. More subtly in Act III, Emily observes her twelfth birthday, almost as if seeing a play. In plays or performances within plays, the outer play becomes the 'limit-of' dimension of the inner play. The limit-of the inner play can imply questions about limit dimensions of worlds for the audience. And when the inner performance (represented through the outer) is a ritual, where communication with transcendence is implied or expressed, then the limit-of implication may become explicit, as with the wedding.

"I play the minister." The Stage Manager's comments here are both metatheatre-1-he addresses us directly-and -2 , for they are a sermon at a wedding. "This is a good wedding, but people are so put together that even at a good wedding there's a lot of confusion way down deep in people's minds and we thought that ought to be in our play, too" (p. 71). Later, in Act III, he will say that "way down deep" we know of something "eternal." Here, the down deep is "confusion." He also speculates on the metaphysics of this "sacrament" (though in the terms of a Congregational modernist, not a Catholic) and tells us "the real hero of this scene" is nature.

It's like what one of those European fellas said: every child born into the world is nature's attempt to make a perfect human being. Well, we've seen nature pushing and contriving for some time now. We all know that nature's interested in quantity; but I think she's interested in quality, too,- - that's why I'm in ministry.

And don't forget all the other witnesses at this wedding,- - the ancestors. Millions of them.

Most of them set out to live two-by-two, also. Millions of them. (p. 71$)^{29}$

If a kind of "interested" nature is the limit-of dimension (for the "perfecting" of human being), it is also the confusion we feel within, where eternity and value are found. What is more, this place at the edge of limit-of and limit-to includes "other witnesses," "the ancestors," an implied audience

27 See Goldstone 1975 , p. 140.

28 Of Jeff Weiss, playing Simon Stimson, Rich, 1998, wrote, "Mr. Weiss, a hollow-eyed and spindly figure in black, haunts Grover's Corners as if he were the repository of its citizens' smashed hopes and the lifelong victim of its mean, unspoken bigotry."

29 Konkle 2018, pp. 20-21, thinks the "European fella" is likely Bernard Shaw (preface to his play Misalliance). 
of "millions" that includes us. As Cromer's staging intuited, we also become positioned in the play's limit-of.

Our Town is aware that ritual constrains liminal confusion imperfectly. To be sure, the wedding frames its dangers comically, even patronizingly. George tells his mother he does not want to "grow old" and Emily asks her father, "Why can't I stay for a while just as I am? Let's go away" (p. 75). Mr. Webb defuses their panic just before the ceremony. When Mrs. Webb tells us (metatheatre-1) how "cruel" it is that mothers must abandon daughters, the stage direction recommends softening humor, "In half-amused exasperation" (p. 72). But only half; her next line may be played to devastating effect: "The whole world's wrong, that's what's the matter." Likewise, the Stage Manager's aside, "Do I believe in it? I don't know." He summarizes life, much as Jacques' speech in As You Like It. We go from "the cottage, the go-cart" all the way to "the deathbed, the reading of the will." Again, Wilder asks for a "smile," against any "cynicism" when the Stage Manager says of marriage, "Once in a thousand times it's interesting" (p. 78). ${ }^{30}$ However, at stake is not cynicism but tragic awareness, ${ }^{31}$ which struggles with Our Town's ontological vision of value and compassion in every moment.

During the wedding, the choir sings "Love Divine, All Loves Excelling" and "Bless Be the Tie That Binds" (also at the funeral). Both lyrics express earthly love recapitulating divine love, in "the fellowship of kindred minds." The script does not specify whether Simon Stimson leads the choir at the wedding; either way would be telling, contrasting his despair with the hymns or else implying he is already gone. In Act I, he rehearses "Art Thou Weary; Art Thou Languid?" and admonishes the choir, "It's a question, ladies and gentlemen, make it talk" (p. 35)—funny, unless it resonates with Simon's "peck of trouble." Dr. Gibbs tells Mrs. Gibbs, who saw Simon drunk at the rehearsal, "Some people aren't meant for small-town life" and "there's nothing we can do but just leave it alone" (p. 40). We next hear from Simon among the dead:

To move about in a cloud of ignorance [. . .]. To be always at the mercy of one self-centered passion or another. Now you know—that's the happy existence you wanted to go back to. Ignorance and blindness.

MRS. GIBBS: Spiritedly. That's not the whole truth and you know it. Emily, look at that star. I forget its name. (p. 101) $)^{32}$

Having died in childbirth nine years after the wedding, Emily returns to relive her twelfth birthday; she is a spectator, as if at and in a play. The Stage Manager had said, "You not only live it; but you watch yourself living it" (p. 91). Emily herself now sets the scene: "There's Main Street... why, that's Mr. Morgan's drugstore before he changed it! [ . . . ] And, look, there's the old white fence" (p. 93, Wilder's italics). I will speak more to this, but in terms of metatheatre-2 and limit, Emily experiences a disjunction between limit-to (the finite edge of a domain) and limit-of (that is, 'beyond' the edge). Wilder's distancing wants us to see more intensely everything and everyone in the theatre space as being superabundantly meaningful or affecting. Theatrical distance is an analog for what Emily experiences upon her return to observe the living. Her impression is that the living do not see, as she now sees, which causes anguish — "Let's look at one another" (p. 99)—and is something to further explore. Yet Wilder lays in the subtle, metatheatre-3 implication that the living do sometimes see, especially when things are set off as if on a stage, even on minor occasions like birthdays.

30 According to Harrison 1983, p. 187, Wilder claimed he meant "interesting" as Gertrude Stein used it, apparently with light irony.

31 See Corrigan 1961, p. 171. In denying Wilder a "religious dimension" because he lacks consistent view of redemptive ultimacy, Corrigan may have imposed an either-or criterion of propositional coherence. In being variously Platonist, humanist, Christian, and tragic Wilder has an awareness of the fragmentary that Konkle 2018, calls postmodern. On the fragmentary, see also Tracy 1999, pp. 170-81.

32 From such passages and a comment by Wilder, McDonald 2018, presses the view that he portrayed human existence and the afterlife as "hellish," comparing Our Town with Sartre's No Exit," in Bryer 2018; this is probably "not the whole truth," however. 
EMILY: With an effort. Mama, I can't find my blue hair ribbon anywhere.

MRS. WEBB: Just open your eyes, dear, that's all. I laid it out for you special—on the dresser, there. If it were a snake it would bite you. (p. 95)

\subsection{Metatheatre-1 (Framing Metatheatre-2 and -3)}

Wilder did not find credible most English language theatre he saw in the 1920s. Consoling to an insecure middle class, it was theatre with surface verisimilitude but lacking the "real." Turn-of-the century drama smothered itself in "box sets" behind curtained prosceniums, and so became "a museum showcase" that "devitalized the theatre." 33 Yet one may reach reality through all sorts of theatre, from naturalism to symbolism to Brecht to the absurd. While Abel speaks of metatheatre aiming for life as dream, stage, and imagination in contrast to the real, he implies that the contrast is itself real, as are dreams and theatrical illusions. ${ }^{34}$ Moreover, a distorting funhouse mirror is still a mirror and can show us how we are. Here, I follow a distinction between naturalism-imitative of nature in acting style and scenography - and realism, a broader category for any dramatic mode that attempts to discern truthfully, even via oddity, surrealism, or farce. An ancient myth or avant-garde fantasy whose actions and motivations appear humanly plausible could have more realism than one without such plausibility.

In metatheatre-1, a play or performance pointedly refers to itself. It makes apparent its edge, with the audience situated just outside its expressive and material world, a participant, strangely, both in the world's 'beyond' (limit-of) and at its edge (limit-to). The Stage Manager is also outer and inner; he not only talks about Our Town but enters its world, taking parts as needed while serving us (and Emily) as a Virgilian guide to time out of time ("that element I merely took from Dante's Purgatory," Wilder wrote, xii). As he and other players directly acknowledge us, we help them define the play's boundary, at once definite, porous, and real. Whenever theatre- -through living players, material objects, and stage space and time that overlaps our space and time-mirrors its own limits, it makes us participants in those limits. We, players and audience, lend our bodily materiality, emotions, and thoughts to the world-domain of the play and its edges. What was an abstract limit achieves concreteness via corporeality, perception, and expression, yet remains an abstraction. This much would be true of all drama, of great naturalism especially (Ibsen, Stanislavski). But Wilder's way of metatheatre-1 doubles-down on making the edge explicit, as the Stage Manager manages the bare stage.

No curtain. No scenery. [. . . ]

This is our doctor's house,-Doc Gibbs'. This is the back door.

Two arched trellises, covered with vines and flowers, are pushed out, one by each proscenium pillar.

There's some scenery for those who think they have to have scenery. (pp. 5,7)

By minimizing scenery, by insisting we think anew about scenery, and by intensifying our awareness of this or that person/actor, Wilder attempts to heighten our sense of material things that are also types or ideal things. This, I take it, is what his metatheatrical realism attempts: the 'merely' imaginary or illusory is realized by our 'being shown' the illusion's 'being made.' A few props, a defined space, and actual, intending persons all lend bodily credence to the imaginary. ${ }^{35}$ The unveiled illusion (which should remain an interesting illusion) becomes like a practical 'argument,' saying: this world

\footnotetext{
Wilder 1957, Preface, pp. x, xi.

Abel 2003, pp. 179-80, on Chekhov.

35 See Scarry 1985, on "analogical verification," which might also be termed "bodily substantiation," pp. 13-14, 21-22. On similar issues, see Gillespie 2019, “Drama Alone Is Credible."
} 
is plausible (perhaps real), not only because you have seen the making of it, but because you are participating in its making and its limits, at its edges and beyond.

Philosophically or theologically, the limit-of for Our Town would be the "something way down deep" that is confusing at the wedding and anguishing when Emily visits her past. The Stage Manager asserts (to us) near the beginning of Act III, "We all know that something is eternal [. . .]." The what is left unstated. Not houses, names, the earth, stars, or identity-yet "that something has to do with human beings. [. . . ] There's something way down deep that's eternal about every human being." At the cemetery, the dead-another 'audience,' in chairs facing us (or among us, in Cromer's staging)—are waiting and being patient (pp. 89,90), for what we are not told. They sit, losing interest in the past. The Stage Manager explains:

Gradually, gradually, they lose hold of the earth ... and the ambitions they had... and the pleasures they had... and the things they suffered .... and the people they loved.

They get weaned away from earth—that's the way I put it—weaned away. (p. 81)

When Emily appears among the dead, she is already in temporal transition. "It seems thousands of years since I. . " “Oh, I wish I'd been here a long time. I don't like being new here" (p. 88). "Live people don't understand, do they? [ . . ] I feel as though I knew them last a thousand years ago [. . . .] Mother Gibbs, when does this feeling go away?-Of being... one of them?" (pp. 89,90). Emily is becoming distant yet also still attached to the living- "Mother Gibbs, George and I have made that farm into just the best place you ever saw. [ . . . . My boy is spending the day at Mrs. Carter's" (pp. 88, 89)—and realizes she can visit her past. The dead and the Stage Manager warn against it: "you see the thing that they-down there-never see. You see the future. You know what is going to happen afterwards" (pp. 91, 92). In her in-between state, her seeing will be finite, like our seeing, but from a vantage point nigh eternity unavailable to the living-except as we share her place, now, with the ancestors.

Mrs. Gibbs says that visiting the past is not pertinent to the dead, who are "to forget all that, and think only of what's ahead" (p. 92), which is never revealed. Yet effective productions create the impression something has been revealed, partly depending on what we can read into it: Paradise? Judgment? Fulfilling insight? Harmony or love? Wilder suggests that the eternal way-down-deep is a superabundance of "value" (xii) immanent in the quotidian moment. Yet this "wonderful" nexus of value and meaning is so distant to ordinary sight that to perceive it retrospectively prompts anguish akin to grief. Wonder becoming anguish is what Emily feels when she returns and sees. "I can't look at everything hard enough" (p. 97). "I can't go on. It goes so fast. We don't have time to look at one another. [ . . .] I didn't realize" (p. 100). Such lines risk sentimentality yet express anguished insight. Penelope Miller found a near perfect balance in the potentially maudlin but luminously devastating farewell, "Good-by Grover's Corners": "Oh, earth, you're too wonderful for anyone to realize you. [. . .] Do any human beings ever realize life while they live it?-every, every minute" (p. 100).

We in the audience are to undergo an apophatic or via negativa discernment like Emily's. We, for a moment, are to see with her. We are to see the invisible by seeing how the living do not see. She and we see the whole of persons' lives-in-time (a limit-to dimension) in individual moments of their lives. This intense perception is not just knowing "what's going to happen afterwards" (p. 92), though is partly that. It is also the effect of temporal and spatial layering: particular past moments seen in light of other past and future moments which, sub specie aeternitatis, are already part of the nexus of meaning. The living see only a little of this polyvalent nexus. Emily discerns it via contrast with the living and supposes them willfully blind. "Oh, Mama, just look at me one minute as though you really saw me" (p. 99). It is not that she sees everything or they nothing. The living do see-“open your eyes"-and the weaning dead see much more but remain limited, as when Mrs. Gibbs rebukes Stimson: "that ain't the whole truth." We now are in a similar predicament as Emily, seeing more of the very much more. The anguish is not exactly grief, if grief entails decathexis, or loss of connectedness. The pain, rather, comes of reconnection, via extraordinary discernment that is more than finite spirits can withstand, except "the 
saints and poets, maybe" (p. 100). A question remaining is why the dead should be "weaned" from the content of this pain. I shall consider that, after comments on other productions that have enhanced this discernment.

Effective realizations of Our Town must be compelling, in respect both to the via negativa mode of discernment and the play's polyvalent disclosures of value, time, and eternity. Lori Ann Laster reports on bunraku puppets, vocalized by actors to stylize and distance the townspeople and which are later sprawled lifeless at the cemetery, "corporeal symbols for the hopeful spirit that swiftly dwindles when one passes over into death." Another company staged Act I as a 'table read' rehearsal led by the Stage Manager, until the moment he turned and explained to the audience that the Grover's Corners bank will deposit Our Town in its time capsule. "By breaking the fourth wall here rather than at the beginning of the play, Amster [the director] made the trope of direct address powerful and immediate."36 Laster also comments on a 2007 production at Connecticut's Hartford Stage, which brought back veteran Stage Manager Hal Holbrook, then 82, who captured “the play's occasionally dry melancholy." All his words about mortality_ "you make some decisions; then whissh! You're seventy" (p. 60)—reflected back on him, no matter how understated. His age was layered over the timeless part. Ben Brantley wrote similarly of Paul Newman, 77, in the 2002 Westport (Connecticut) Country Playhouse production. Again, memories of a long film career overlaid his wry, rumpled Stage Manager, who seemed to be "inventing his lines on the spot," without the direr ironies of Spalding Gray. ${ }^{37}$

Timelessness cannot directly be represented by finite, temporal art. A very old Stage Manager can do so indirectly: the more years, the more timelessness. However, in 2002, the Transport Group did Our Town in New York, which I saw. Director Jack Cummings III cast against age: George and Emily (Tom Ligon and Barbara Andres) were in their sixties, with a Stage Manager played by Emma Orelove, age 12. Music and a prologue were added, of quotable lines from the play's wisdom; lighting effects and projections created a cool, autumnal, abstract space. The play kept to Wilder's minimalism, so the major innovation was the actors' ages.

From reviews, my guess is that old George and Emily were better received than the child Stage Manager. Anita Gates saw George and Emily much as I remember, having "within them the middle-aged couple they're destined to be, as if the gray-haired adults can fulfill the dream of being with their parents in their youth and vigor again but knowing what they know now." ${ }^{38}$ Not only do we see them as they might have become but, more subtly, we see two superimposed lifelines, as if both had reality. Simultaneity of this sort may or may not have been anything Wilder anticipated. Even so, given how he played with Augustine's and Dante's views of the presence of eternity to past, present, and future, juxtaposed with a modern picture of the future as unrealized possibilities, a 'real' simultaneity may be implied in his vision of superabundant value in the unseen eternal. ${ }^{39}$ Some thought Orelove could not credibly deliver the crusty nuances of a Gray or Holbrook, but this was to miss the point. Rather than speaking from worldly wisdom, she spoke from ageless simplicity. Or so was my impression, and I still find her interpretation valuable. Yet this is a time to take up a question hinted earlier about Wilder's vision of near infinite value layered in every moment.

Why would it be good for the dead to be weaned from meaningful, albeit earthly attachments: ambitions, pleasures, "the things they suffered... and the people they loved"? Why should they become "indifferent" as they wait "for the eternal part of them to come out clear?" Because of the anguish of such knowledge? (Best to "forget all that," says Mrs. Gibbs, among the dead.) Because a

36 Laster 2008, highlighting 2007 productions by the Two River Theatre Company of Red Bank, New Jersey (directed by Aaron Posner-with puppets); the Indiana Repertory Theatre of Indianapolis (directed by Peter Amster-as if a table reading); and the Hartford Stage (directed by Gregory Boyd-with Holbrook).

37 Brantley 2002, review of Our Town as directed by Mark Lamos.

38 Gates 2002, review of the Transport Group production of Our Town, directed by Jack Cummings III.

39 Konkle 2018, p. 21, notes the Stage Manager is simultaneous to all times in the play, 1899-1913 (and 1938 and the date of any performance). Temporal simultaneity is not just biblical-medieval but reappears as a poststructuralist view of semiosis synchronically levels discourse into the intertextual all-in-all. See Mark C. Taylor 2004, "Betraying Altizer." 
fuller perspective on the past would distract from preparing for "what's ahead"? Moreover, should not the Stage Manager know what is ahead? He should, if we take him to be a God-figure. ${ }^{40}$ There may be aporias here, forgivable given the impossibility of answering such questions; Wilder may have been simply (or way-down-deeply) inconsistent.

However, Wilder's reference to Purgatorio leads me to think the Stage Manager is more a Virgil-figure, who in Dante knows that there is redemption but has only a vague notion of what redemption is. The analogy breaks down, of course, for the Stage Manager is among the living ("we're coming up here ourselves when our fit's over," p. 81), and Wilder suppresses references to Christian atonement except in the hymns. Our Town is a better play, however, if the Stage Manager, like Dante's Virgil, knows a lot but not everything, with more of a grasp of limit-to than limit-of. He may not know for what clarity the dead await, nor whether "weaning" is the best metaphor for their waiting. Might he be just a bit of an unreliable narrator? In any case, old men with silver hair are reminiscent of a folk picture of God Wilder would never endorse. Whereas, a red-haired twelve-year-old evokes no such cozy familiarity and might for that reason be a very appropriate guide.

\section{Sundays in the Park}

If there are God figures in Sondheim and Lapine's Sunday in the Park with George, they are not the artists who make aesthetic worlds, but "Sunday," the song that soars from the tableau-vivant of Seurat's painting before each act ends. ${ }^{41}$ There is, however, a Beatrice-figure, Dot, who answers a limit question left begging by Emily and the Stage Manager: why should the dead be "weaned" from what the living do not really see? Her answer to George and George, from a theatre-magic place at once present to past and future, is simply that we, the living, do . . . see. Dot sings, "Give us more to see ..." (p. 198). She invites us into such a place of participatory discernment.

Although conventional God figures can allegorize conceptions of limit-of (the 'beyond' of a horizon of discourse and experience), as conceptions they are arguably limit-to. A conception of the divine or ultimate may, at the level of experience, imply a question of boundary without participating in a movement of mind and feeling beyond it, as a symbolic, aesthetic, or ritual process might. Are there religious premises and questions in Sunday in the Park analogous to Our Town's? There are no sacred hymns, rituals, sermons, or prayers. Implied weddings and funerals occur outside the scenario (though testimonials to Seurat in Act II are like eulogies), and there are few religious words (a reference to "Ascension Day 1884," when Seurat began the painting). Even so, Sunday in the Park evokes limit structures related to creation and revelation and to discernments that transcend time. So, when the 1884 Dot appears to the 1984 American artist George on an island in the Seine, she is also appearing to her lover, Georges Seurat (died, age 31). Speaking and singing with Dot (whose old grammar book he carries), the postmodern George is also conversing with his grandmother Marie, Dot's daughter, who kept the book and has just died, at 98 . When he ritually reads Seurat's words of transcendental efficacy, much like Platonic aesthetic forms-Order, Design, Tension, Composition, Balance, Light, Harmony, which Dot copied in the book-it is as if Seurat, Dot, Marie, and George become simultaneous. First played by Mandy Patinkin and Bernadette Peters, they sing of "parasols" and "People strolling through the trees/[. . .] On an ordinary Sunday" (pp. 201, 202). ${ }^{42}$

Up to this point of intergenerational hyper-connectivity, Act II has been problematic. It competes with the amazing set pieces of Act I, where Neo-Impressionist masterpieces come to life, principally Seurat's Sunday Afternoon on la Grand Jatte (1884-1886), also Bathers at Ausnières (1884) and Young

40 As does Von Balthasar 1988, pp. 351-52, and Konkle 2006, p. 142.

41 The artists are the fictionalized Georges Seurat (1859-1891) and his entirely fictional great grandson, George, in 1984 (the year the completed musical opened; Act I was performed in 1983). No character in Act I refers to "Seurat," always "George," but to avoid confusion I usually refer to this character as Seurat.

42 PBS broadcast this production on American Playhouse in 1985. I am indebted to comments from Austin Bouchard, whom I saw play George at the University of Mary Washington in 2014, directed by Gregg Stull. 
Woman Powdering Herself (1888-90). Act II also competes with stories imagined from figures in the painting: earthy and finer folk, some at odds with each other and Seurat, who studies and corrals them into his composition. What Dot calls his "mission to see" (p. 109)—theorized as pointillism and chromoluminarism - is in conflict and contiguity with his inarticulate feelings for her-mistress, model, and unacknowledged muse. By contrast, the George of Act II is an electronic sculptor-inventor whose Chromolume series would fulfill, he hopes, Seurat's dream "to paint with beams of colored light" (p. 147)

Any production of Sunday in the Park must deal with how Chromolume \#7, though important to George and indeed intriguing, is not clearly compelling as an artistic "invention." On one hand, everyone except Marie doubts it, including eventually George himself. Should productions make the device better than it is, or bring it 'up to date' with electronics unavailable in 1984, they risk overshadowing the final, theatrically simple appearance of Dot, or else contradicting "Putting It Together," a number that while cynical makes some astute judgments. Recall that Seurat had employed materials, paint and brushes, used for centuries. Whereas whatever gadgets George uses, be it lasers or "a new state-of-the-art Japanese microcomputer which controls the voltage regulator" (p. 149), a Chromolume will date itself the day it switches on. The electronic music accompanying it, and briefly shorting it out, may also date it. And while Act I imagines a variety of near archetypal figures-mistress, elegant artist, rough boatman, soldiers, animals, baker, fisher girls, mothers, nurse, dandy, children ${ }^{4}$ - George in Act II must hobnob with dubious brokers from the modern art racket.

On the other hand, we must not miss George's serious intent with the Chromolume, not only for his life and art but also for thematic connections to Seurat. A 2017 New York revival, directed by Sarna Lapine (James' niece), approximated pointillism by trading laser beams for firefly patterns from many small, suspended lights rising, falling, and changing color above the audience. ${ }^{44}$ We learn in Act II that Seurat lived only a few more years, leaving us to imagine his work, had he lived, overlapping Kandinsky, Braque, Mondrian, and Picasso. We may glimpse in Act II's George, then-as with the older Emily and George in the Transport Group's Our Town-unrealized possibilities and limit dimensions of Seurat's life, art, and love. Sarna Lapine also believed "the piece itself was about transcending time." ${ }^{45}$

When Sunday in the Park moved from Playwrights Horizons to Broadway's Booth Theater in 1984, directed by James Lapine, its design was quite literal. There were flying and sliding flats approximating the park-painted trees, water, grass, sky, later the modern buildings-and life-size cutouts of figures not enacted, including two dogs, a monkey, and the Soldier's Companion. In Act II George, bored with guests at the museum reception (the same actors from the painting in Act I), "raises up" photographic cutouts of himself for them to talk to, which added jaded fun to an already satiric scene. (The cutouts are specified in the published text.) The 2017 revival evolved from a 2016 concert production at New York City Center with Jake Gyllenhaal as the two Georges and Annaleigh Ashford as Dot and Marie. Of the full production at the Hudson Theater, Sarna Lapine describes decisions to remain minimalist with a small playing area. The scrim with projected impressions of the painting also allowed audiences to see the orchestra; the effect suggested a canvas in a park for some simple performance. Gone were the cutouts (except for the dogs). Acting choices also made for a more integrated story, in respect to the character links and contrasts between the acts. With such possibilities in view, let us see how metatheatre configures 'limits' in Sunday in the Park with George.

43 On the painting's history of interpretation, many coalescing around class differences, see Herbert and Harris 2004, pp. 152-69. Had it come earlier, Herbert's own interpretation, pp. 170-75, of "fashion and irony" in the painting could have informed the play's metatheatricality.

44 I am unsure of this device, though some liked it; see Brantley 2017, reviewing the Sarna Lapine directed revival. On a YouTube video of the whole show, shot obliquely from the audience, the effect seems disconnected from the production's otherwise intimate staging; it did provoke an enthusiastic reaction.

45 Myers 2017, interviewing Sarna Lapine (accessed 31 July 2019). The Interval stopped publishing on June 20, 2019. I will keep available this interview for anyone interested. 


\subsection{Metatheatre-1}

Although both Seurat and George manage stages (Seurat poses people and shows his work to Jules, a rival artist; George publicly introduces his Chromolume and cajoles patrons at the reception), neither directly breaks the fourth wall like Wilder's Stage Manager (though they may carry scenery such as cut-outs). The two Georges remain in their fictive worlds, except for the play's first lines, where Seurat is in lecture mode: "White. A blank page or canvas. The challenge: bring order to the whole" (p. 21). Then he intones a litany of aesthetic principles-from design to light and harmony-and with each word, the park's trees, sky, landscape, and water appear. A perennial conundrum in aesthetic epistemology is whether artists find new worlds or create them, or find them through creation. Are Seurat's aesthetic principles eternal forms beyond the mind or Kantian a priori that live within? The question goes to Tracy's distinguishing limit-of from limit-to-that is, the inferred ontological ultimate from the experienced, ontic boundary. Sunday in the Park will not resolve this question but keeps returning to it as it articulates and crosses metatheatrical edges and limits.

Musicals break the wall with their 'numbers,' listed by title and character in the program. Even when integrated with the plot, numbers can be showstoppers, necessarily sung to $u$ as well as to other characters. Numbers are as much commentary as story, establishing themes and ranges of emotion. As if to say to us, "We are at a musical" and indeed we are in it, for our applause affects the show's momentum. All this is true in Sondheim: people burst into song and tell you how they feel and what is going on. Yet the boundaries of his numbers are harder to demarcate, especially on the printed page where, in Sunday in the Park, they read smoothly together with the unsung dialogue. ${ }^{46}$ In this way, Sondheim's numbers are like Wilder's Stage Manager, who talks to us and to various characters.

Dot, however, frequently does speak retrospectively to us in Act I, and so is more a metatheatre-1 presence than Seurat. Her first number, "Sunday in the Park with George," comments on the world the song establishes and values: "there are worse things" than posing in the summer for your artist-lover "On an island in the river on a Sunday" (p. 30). By the first act's end, her appreciative complaint has become "Sunday," hymn-like in emotion and which articulates Seurat's method of color juxtaposition. Colors mix not on the canvas but "in the eye." And despite the stasis of these figures 'living' forever in a painting, the song suggests liminal passage toward a verticality within but not of the limits of 'ordinary' time. ${ }^{47}$

Sunday,/By the blue/Purple yellow red water

On the green/Purple yellow red grass,

Let us pass through our perfect park [. . .],

Through arrangements of shadows

Toward the verticals of trees/Forever ...

[....]

On an ordinary Sunday ... (pp. 127, 128)

Then, at the play's finale, before the stage becomes a blank canvas and George says, "So many possibilities," "Sunday" reprises as he reads Dot's note in the grammar book about her George, "So much love in his words ... forever with his colors ... how George looks ... he can look forever ... what does he see?" (p. 201). "Sunday" frames the simultaneity Dot and the two Georges share with each other and with Marie. And the song frames us in the limit dimensions of the play, 'beyond,' 'at,' and 'within' its world (especially if we happen to be enjoying a Sunday matinee).

46 See Sondheim 2011, Look, I Made a Hat, pp. 6, 17.

47 The play's Sundays are during summer. Gillespie and I wonder if Sondheim and Lapine were alert to the Christian liturgical meaning of 'ordinary time' after Pentecost in the spring. 


\subsection{Metatheatre-2}

To witness art within art or plays within plays can be analogous to revelation. To stage a drama within a drama can be an analog to creation, as when Hamlet penned a new version of The Murder of Gonzago. Yet the limit, there, is more about creation's limit-to than limit-of. Hamlet plays not God but detective; he contrives a theatre-place in which to observe what none can see, the within of another mind. He intends his murder-mystery to prompt Claudius to reveal himself, yet there are reasons to think Hamlet only sees what he expects to see. Claudius remains opaque a while longer. If there is a limit-of dimension in Hamlet's playing within and without, that dimension is rather literally us. With Hamlet we see Claudius apparently at prayer, but only we hear what weighs upon his conscience. We are positioned in Hamlet's limit-of, in its regions beyond, as if participating in a divine or Shakespearean judgment-at least until judgment turns back upon us, finding us again within the play, with Claudius and Hamlet. Yet surely the art within art in Sunday in the Park is not of anything so morally fraught as murder.

The story goes that Sondheim, discouraged by the flop of Merrily We Roll Along (1981) and swearing off theatre, met playwright Lapine and discovered they shared an interest in Seurat. Sunday in the Park was in effect born of conversations before a painting. ${ }^{48}$ As Sondheim wrote the songs and score, he imagined Act II as theme and variations on Act I, but Lapine knew it would require a connected story. Thus, the invention of a great-grandson who makes conceptual art a century later and only half-believes his grandmother is the bundled-up baby in Grand Jatte. So, the musical was conceived both as a painting within a play and a play within a painting. The painting, moreover, is 'in' images the script indicates are projected by the Chromolume, whose principles of light derive from principles in the painting.

In Act I, analogs to plays within plays come when art is performed, chiefly by Seurat. He poses, draws, and paints Dot and the quarrelsome folk who frequent the park on Sundays, including his mother (who pretends not to recognize him!) and two dogs whose doggy conversation he mimics in "Day Off." His most important performances are with Dot, whom he teaches to "concentrate," and in the studio as he demonstrates pointillism. Act II begins with a tableau-vivant within a play; the figures in the painting, itchy in an eternal now, complain, "It's Hot Up Here." "Putting It Together" also has metatheatre-2 characteristics but will better serve the discussion of meta-3.)

Dot finds posing torturous and thinks concentration is merely "the art of being still" (p. 46) while being arranged like an "object" (p. 30). A moment of metatheatre-2 involves the actor, originally Peters, stepping out of her rigid dress to strike sexy modeling poses. (In 2017, Ashford played it without the costume-prop effect and with more seductive affection for Seurat.) Dot imagines herself in the Follies as she applies powder and makeup—-more rouge"-much as he paints-"more red" (pp. 48-50). Yet when Dot reappears in Act II, she has learned that concentration is a form of discernment akin, I take it, to today's 'mindfulness' or more ancient practices of contemplation. She tells George (i.e., Seurat and her great-grandson) that he gave her "concentration."

At first I thought that meant just being still, but I was to understand it meant much more.

You meant to tell me where I was-not some place in the past or future. I worried too much about tomorrow. I thought the world could be perfect. I was wrong. (p. 194)

We could postpone Seurat's theory of color for metatheatre-3 (the drama-theatrical, artful facets of ordinary life), but since we see him painting and explaining his painting, metatheatre-2 fits. In "Color and Light" Seurat, intermittently aware of Dot whom he loves and emotionally neglects, applies points of paint to an unfinished Grand Jatte:

48 Secrest 1998, pp. 326-28. Zadan 1986, p. 308, reports that Patinkin in preparation spent hours with the painting at the Art Institute of Chicago. 
There's only color and light./Yellow and white.

Just blue and yellow and white.

(Addressing the woman he is painting)

Look at that air, Miss. [. . . .] That's done with green ...

(Swirling a brush in the orange cup.)

Conjoined with orange. (p. 48)

Pointillism and chromoluminarism should be distinguished, though the play mentions neither term. ${ }^{49}$ Seurat's pointillism used dots or tiny daubs of paint without blending them on the canvas. To suggest this, Patinkin in 1984 stood facing the audience while behind a transparent scrim (with the unfinished painting projected on it) as notes matched his staccato brush strokes. Gyllenhaal, in 2017's staging, simply faces us as he paints, which would more emphatically position us in the painting's world of dots. If so, we 'are' both among those whom Seurat is painting-figures in Grand Jatte-and witnesses to his creating. And since in live theatre the audience is among the performance's creators (for we lend it our perceptive attention, without which it is not) a collaborative relation is obtained: we 'paint' Seurat, as Seurat paints us. What makes our participation in the play's limits more than an enjoyable curiosity are questions of responsibility to and for art, and to and for persons, in the present and over time, which the painting and play raise in miniature and at large. In miniature, these questions arise with chromoluminarism.

Chromoluminarism is a technique of juxtaposition. Particles of adjacent, different colors create the shimmer of a third. Seurat asks Jules about a flower on a hat, "What is the dominant color?" Violet, but look closer and one sees dots of red and blue. "So?" "So, your eye is perceiving both red and blue and violet. Only eleven colors-no black—divided, not mixed on the palette, mixed in the eye. Can't you see the shimmering?" Apparently not, "You are a painter, George, not a scientist!" (p. 103). George and Marie in Act II also explain:

Having studied scientific findings on color, he developed a new style of painting. He found [. . .] that at a certain distance the eye would fuse the specks optically, giving them greater intensity than any mixed pigments.

MARIE: He wanted to paint with colored lights.

GEORGE: Beams of colored light, he hoped. (p. 147) ${ }^{50}$

The conception is not only a matter of color consciousness. Juxtaposition creates space for worlds to emerge at the boundaries or in the gaps between what is juxtaposed-whether it be simply a world of color or a rich, thematic world. Such is the point of "Finishing the Hat," where the art story and the lovers' story cross. Dot leaves Seurat, who did not take her to the Follies because that evening, as on other evenings, he had to "finish the hat." She has left him for an emotionally more reliable "artist," Louis the baker ("he kneads me/I mean like dough, George," p. 95), who marries her though she is pregnant by Seurat. He is also rejected by the jealous Jules. Seurat's painting can be understood as an expression as much as impression, for when light comes together- "dot by dot"—a world emerges with the object. "Coming from the hat,/Studying the hat," you are

49 Chromoluminarism was Seurat's term, changed to divisionism by Paul Signac. See Jane Block, "Pointillism," Oxford Art Online/Grove Art Online, (Block 2003), https://doi.org/10.1093/gao/9781884446054.article.T068278 (accessed July 30, 2019). Grand Jatte did not begin as pointillist; Seurat introduced dots and tiny marks in later phases (Herbert and Harris 2004, p. 111).

50 Herbert 1968, pp. 18-20, rejects the movement's claim that colors optically and objectively mix 'in the eye' at given distances but affirms the shimmering effect for the viewer. The play's violet example is a little misleading, for the colors Seurat juxtaposes need not be primaries. 
Entering the world of the hat,

Reaching through the world of the hat

Like a window,/Back to this one from that.

"Like a window" can associate with religious icons, often described as transparent to the spiritual realities they represent. And this window seems a two-way passage to objects and to persons.

Studying a face,/Stepping back to look at a face

Leaves a little space in the way like a window,

But to see-/It's the only way to see. (p. 94)

Do these faces precede the artist, to be encountered like living Platonic forms, or do they proceed from Seurat's ways of composing and juxtaposing worlds? Well, it's ambiguous. He shows a sketch to Fifi, a yappy dog in the park: "Look, I made a hat.../Where there never was a hat" (p. 95). He tells Dot that while caring "about many things" and "People too," he is "not hiding behind my canvas-I am living in it" (p. 107). Dots of color set beside other dots, and persons in arrangements with other persons create spaces for life. That what he tells Dot rationalizes his neglect need not diminish its possible truth. In "All Things Are Beautiful," when his mother fears losing the view from the park to developers clearing space for the Eiffel tower, he explains, "I'll draw us now before we fade, Mother [. . . . ] You watch/While I revise the world" (p. 113). Yet the song leaves open what Tracy might view as the limit question of whether artists make, or revise, or discover a beauty transcendent to the artist's purposes in the world.

Jules is of the opinion, later retracted, that Seurat's work has "No Life," is "density/Without intensity," and "mechanical" (p. 39). These criticisms ignore enigmas in the painting, the couples and solitary persons whose stories beg to be imagined: who are they, how are they so calm, why are they here? The mechanistic critique is literalized in Act II, for George demonstrates a machine, provoking some guests to say that if his Chromolumes were ever new, they are not new now. The critique is framed by the meta-critique of "Putting It Together," which cleverly treats artistic collaboration as money-chasing expediency. This number is fun and cynical ("Every time I start to feel defensive,/I remember lasers are expensive," p. 166) and introduces tensions, even contradictions that Sunday in the Park strains to make productive.

\subsection{Metatheatre-3}

An implication of chromoluminarism is that color and retina cooperate, or that nature and spirit are mutually implicated—one of the "Romantic principles" (p. 145) George says Seurat superseded through "scientific" understandings of color and light. However, that the mind brings to proximity red and blue (nature) to make and reveal violet, and that the violet discloses value and meaning (spirit) remain broadly Romanticist ideas though classically staged (in Grand Jatte's ancient Egyptian stillness and harmony). A corollary would be that violet emerges from a collaborative performance between blue and red, and between artist and viewer. ${ }^{51}$

So, if the cynicism of "Putting It Together" implicitly assumes that authentic art could only arise from individual, untainted genius—and thus doesn't really arise at all—then it undercuts the play's premise, namely that art and life, at once internal and external to one another, cannot happen alone but are inherently collaborative. The jaded spirit of this long number (about eleven minutes) may pander to an antitheatrical nostalgia for a 'being not seeming' it knows it can never have. Art generally and theatre especially requires people, money, and criticism; "Putting It Together" knows this but risks casting it as a slur. The "antitheatrical prejudice" is part of an anti-aesthetic bias that would

51 See McLaughlin 2016, p. 159 
favor purity, authenticity, and sincerity. Inasmuch as forms of these biases occur throughout cultures, notably when they comment on their arts, it is crucial that art and theatre explore and revise these prejudices and pre-understandings. ${ }^{52}$

The stories in Act I masterfully show this exploration. Does art disclose common life or cover it over? Does it distance us from the real or find the right distance to see? When the one-eyed Boatman calls "hypocrites" the upper crust people visiting the park, the kind who pay for fine paintings, he repeats an ancient trope. (In Greek, the term was idiomatic for actors.) Yet for a moment, he finds common spirit with Seurat. "You and me, pal,/We're the loonies [. . . . ] 'Cause we tell them the truth [. . . .]You and me, pal,/We're society's fault. (pp. 82, 83). Whereas the German coachman Franz doubts artists really work. "Artists work," his wife Frieda counters, "I believe they work very hard." "Work is what you do for others," Franz sings, "Art is what you do for yourself" (p. 79). Nearly all the Act I characters comment on art, class, and their tasks and status in life. The point is that Seurat (the musical painter) succeeds in bringing them into uncomfortable yet ecstatic collaboration, as they sing "Sunday" and take us to and beyond the temporal and spatial limits of ourselves.

By contrast, the cross section of George's acquaintances at the Act II reception is rather narrow; in one fashion or another, they are from the art-business world. Act II is less of the art than the artist, and about whether George can overcome disconnectedness in his circle of relations. The "state of the art" partygoers patter on about the "new" and trivialize it. They even trivialize Seurat: "the painting's overrated" (p. 177). Yet a few make valid points, especially George's technician Dennis and the art critic Blair Daniels (played the actor playing Seurat's mother). "You were really on to something with these light machines-once. Now they're just becoming more and more about less and less." A danger is that her judgment, if not played with nuance, will also apply to this section of Sunday in the Park. ${ }^{53}$

In the 1984 production, George sang over Blair's sentence and set up another cutout of himself for her to criticize: "Not that you couldn't succeed by doing Chromolume after Chromolume-but there are new discoveries to be made, George" (pp. 174, 175). ${ }^{54}$ The parody may deflect validity from her critique. However, in 2017, Sarna Lapine spent much time developing character links between the acts, including Marie and Dot-as muses to the two Georges-and between Blair and the idea of "mother as first critic." 55 Dispensing with cutouts, the players merely froze in place during George's asides in "Putting It Together," but Blair (Penny Fuller) did not freeze, so her perspective came through. She softened the satire yet deepened it, giving it personal and felt validity. Dennis and Dot will speak similarly. Dennis has decided the Chromolume on the island will be his last. He knows George is repeating himself and George knows too: "I just want to do something I care about" (p. 190).

Of those at the museum reception, only Marie has unqualified praise for her grandson's Chromolume. Fatigued from the presentation and seeing that George is "blue," she discerns value in his creation. From her wheelchair, she turns to Seurat's La Grand Jatte, which hangs near them, and sings as if to her mother.

I don't understand what it was,

But, Mama, the things that he does-

52 On common prejudices against theatricality, see Barish 1981. On the positive significance of "prejudice" and revision in understanding, see Gadamer 1989, pp. 265-71.

53 McLaughlin 2016, pp. 160, 166, implies that despite their sophistication, the partygoers share with Seurat's critics a naive bias, namely that for art to be authentic it must correspond to privileged reality. If so, their portrayal of art as merely an illusory power game contradicts their incipiently realist assumptions. They cannot reconcile how it is through artifices and social collaborations that art—and theatre—can "revise the world" and make it "beautiful" (as Seurat says in "Beautiful"). They are antagonists to the art trends they chase and as unable to see as Jules was unable to see La Grand Jatte. My worry is that if Sunday invites us to be too cynical about these cynics, it may inadvertently join their cynicism and short circuit (like the Chromolume).

54 In a 2005/2008 London/New York revival directed by Sam Buntrock, which used digital animation for paintings and scenery, the cutouts became video projections of George (played by Daniel Evans). "With all these "multiple George-representations seeming as real as George, it is no wonder he becomes confused" (McLaughlin 2016, p. 164).

55 Myers 2017, interview with Sarna Lapine. 
They twinkle and shimmer and buzz-

You would have liked them .../It .../Him ... (p. 184)

Marie (like Dot) is a muse of relationality who connects the new of the now with "Children and Art." ('You know, it is all you really have," p. 181.) She sees her mother in all the painting's people. "Mama is everywhere,/He must have loved her so much ..." (p. 185). "See how she shimmers-/I mean from the heart" (p. 186) As did Wilder, Lapine and Sondheim juxtapose daily relationships with the artistic and natural sublime-and with the theatrical sublime, if we regard both Sunday in the Park and Our Town as making the commonplace disturbing or astonishing. Just as Wilder risks pathos with Emily's "Goodbye Grover's Corners," Sondheim risks cliché with "Move On," but allows music and voice, with emotion and intelligence, to lift truism into insight.

DOT: Stop worrying if your vision/Is new,

Let others make that decision—/They usually do./Move on. (p. 197)

George, despairing of his vocation and missing personal "connection," goes to the island in Paris with Dennis to present one last Chromolume. Marie was to have come too but has died. Dot, dressed as in the painting, appears and thanks George qua Seurat for what he "gave" her and asks, "Are you working on anything new?"- the old query but here asked with love. She knows striving for the new risks contradicting ordinary beauty and light. To my eye, "Look at what you've done/Then at what you want,/Not at where you are,/What you'll be" (p. 197) makes only a little semantic sense. Is not "where you are" something to be discerned, attentively? Yet the dialectic of the new and the ordinary is resolved and exceeded by Dot's "Anything you do/Let it come from you./Then it will be new./Give us more to see" (p. 198).

Recall the question left by Wilder: why should the liminal dead be weaned from associations, memories, and relations layered in each moment, which in life we cannot really see? Well, we are finite. Superabundant possibilities, which in all relationships are real yet unrealized, would be anguishing to see at the limit betwixt time and eternity. Sondheim and Lapine answer that we the living can and do "see." In transformed moments, we discern the flecks of light, sound, and meaning, here approximated by music, lyric, stage, and the story's superimposition of Seurat, Dot, and Marie with George. These graced times of seeing together return us to the metatheatre- 3 of chromoluminarism. If colors in nature are juxtaposed and mixed in the "eye," not just the palette, then we are all dramatists of color and life, with responsibilities there entangled. Every perception sets for us a mission of feeling, thought, and connection. Even in such tiny moments of perception, we are offered the gift of an obliging, so to speak, a call to respond or give attention to whatever sense of spirit (Geist or pneuma) we face before or beyond Tracy's limit-question, "Why be ethical?"

I think that is why the last seconds of Sunday in the Park will move us, if we too can see "so many possibilities..." that George sees in a "blank page or canvas" (p. 202). Mandy Patinkin played this as an instant of insight, Jake Gyllenhaal as a moment of perplexity, perhaps of regret like Emily's. A regret I have is how the final tableau is specified, as the "characters from the painting" promenade again and take their places in "Sunday." I wish they were also their modernist counterparts from Act II, in 1980s-2000s dress but with the same slow movements and settling into their same positions in the painting. The isle of Grand Jatte and people there today are not without value; the greens are darker, the sky greyer, and the water muddier, George tells the spirit of Seurat's mother. "But the air is rich and full of light" (p. 200). 


\section{Conclusions}

That drama and religion connect through ritual must be qualified by the observation that theatrical drama comes into its own only when it is no longer ritual but, say, entertainment or education. ${ }^{56}$ Even when 'to entertain' deepens to 'discern attentively,' the ritual-drama relation can be a puzzle. Does ritual discern? Does entertainment ritualize? Well, 'both,' or 'sometimes,' no doubt. That issue aside, this essay proposes to understand religious dimensions in theatrical drama through concepts of limit. Limit experiences and questions speak to orientations and disorientations toward 'the real' as they become pertinent to theatre, ritual, and religious traditions. Metatheatrical relations can lead us to explore where embodied worlds and horizons meet, differentiate, overlap, and make claims on us. Theatrical drama invites, even impels, us to discern limits and 'otherwise' possibilities of life, together.

Metatheatre-3 is probably the hardest case for my claim, even though the mode registers the "histrionic sensibility" 57 of human experience. Namely, that (1) we 'play' or are 'played' by multiple social-personal roles and parts; (2) we enjoy imitating, for others, such play; and (3) we especially enjoy witnessing and learning from theatrical imitations. The word histrionic signals the problem. As with much theatre lingo transferred to life, it is pejorative, suggestive of feigned hyperbolic emotion, insincerity, or inauthenticity. The opposite insight, though equally old-that by rehearsing social parts to the point of in-habiting them we become who we are with and for one another-does not seem so quickly to come to mind. I sense antitheatrical bias in some performance theory that would expose a cultural achievement or some purported universal as being merely a power-inflected construct or illusion. Universals, however, straddle the difference between limit-to and limit-of. As Plato and Aristotle differently argued, universals are immanent in our particular constructs of experience, yet also transcend them, making our meanings finitely shareable. Metatheatricality explores this straddling of the limits 'to' and 'of' shared experience. Yet an unacknowledged preference for solitary authenticity is detectable in "Putting It Together." Most of its characters not only assume we should have no illusions, but that it would be better if our lives, somehow, were not contingently and artificially constructed, even though we know better. Ambivalent critiques of this sort neglect to explore possibilities of honestly collaborative constructs, in social life or in art. A construct can point beyond itself and give rise to feeling and thought.

Metatheatricality in Our Town can also seem antitheatrical in its minimalism. ("There's some scenery for those of you who think they have to have scenery.") Wilder's claim, however, is that by minimizing the smoke and mirrors and allowing us to see how they actually work, the play substantiates the universals it hopes we acknowledge but cannot 'see.' That is, life-transcending value-immanent "way down deep" in every moment and nexus of life-is made real through discernment and bodily proximity. We are to feel the weight of universals pressing on our skin as we are side by side with people constructing and querying them. In Sunday in the Park, the emphases on constructing and deconstructing are more elaborate; the play's bravura design both minimizes and maximizes the 'magic of theatre' and risks 'shorting out.' But in so doing, it reveals and values limits and possibilities in different ways than Our Town.

Our Town was so metaphysically confident in inherent, quotidian value that it could leave the ultimate limit-of unarticulated. We know only that as we wean from the cares of this world (limit-to), we await and prepare for "something" eternal. If, like Emily, the dead in their in-between state choose to see their finite interrelationships sub specie aeternitatis, it can be devastating, unless with a saint's eye or poet's. By contrast, Act II of Sunday in the Park has little metaphysical confidence as it exposes the pragmatics that puts art together. Yet Act I, which also shows art to be socially as well as aesthetically constructed, ${ }^{58}$ does have confidence in ordinary perception. It is in the eye and ear (limit-to) that

56 See Friedrich 1983.

57 Driver's phrase (1970), p. 262; his point is that technological modernity loses this impulse, to the detriment of drama.

58 McLaughlin 2016, p. 155. 
the performative universals - design, tension, harmony-mix to manifest the plethora of possibilities (limit-of). There, as the play ends on the island, a simpler magic of theatre allows us see, with George, a transcending 'more': Dot enters, there and now, across times and spaces. Sunday in the Park is confident that those among the living will perceive possibilities of love and art in the moving 'now,' sub species aeternitatis et theatrum.

Oh-just as I had a notion for restaging the Grand Jatte tableau at the end of Act II, I have one for the Chromolume. Be apophatic. Do not show the machine, not even its piercing lasers or dancing dots. ${ }^{59}$ Just show the faces of the guests being illuminated by light-I suggest a wash of bright but calm light, with quieter music - as they make of the Chromolume what they will, differently. Let their faces show the limits and possibilities of that new story.

Funding: This research received no external funding.

Conflicts of Interest: The author declares no conflict of interest.

\section{References}

Abel, Lionel. 1963. Metatheatre: A New View of a Theatrical Form. New York: Hill and Wang.

Abel, Lionel. 2003. Tragedy and Metatheatre: Essays in Theatrical Form. New York: Holmes and Meier.

Austin, John Langshaw. 1962. How to Do Things with Words. Cambridge: Harvard UP.

Bakhtin, Mikhail. 1981. Discourse and the Novel. In his The Dialogic Imagination. Translated by Caryl Emerson, and Michael Holquist. Austin: University of Texas Press.

Barish, Jonas. 1981. The Antitheatrical Prejudice. Berkeley: University of California Press.

Bell, Catherine. 1992. Ritual Theory, Ritual Practice. New York: Oxford UP.

Block, Jane. 2003. Pointillism. Oxford Art Online/Grove Art Online. Available online: https://doi.org/10.1093/gao/ 9781884446054.article.T068278 (accessed on 18 February 2020).

Bouchard, Larry D. 2009. Religion and Literature: Four Theses and More. Religion and Literature 41: 12-19.

Bouchard, Larry D. 2014. Dramatic Ways of Being Religious. In The Oxford Handbook of Religion and the Arts. Edited by Frank Burch Brown. New York: Oxford UP, pp. 162-81.

Brantley, Ben. 2002. Review of Our Town. New York Times, December 5, section E. 1-2.

Brantley, Ben. 2008. Review of Sunday in the Park with George. New York Times, December 2, Arts section.

Brantley, Ben. 2017. Review of Sunday in the Park with George. New York Times, February 23, section C. 5.

Brecht, Bertolt. 1966. Galileo. English version by Charles Laughton. Edited by Eric Bentley. New York: Grove Press.

Bryer, Jackson R. 2018. Thornton Wilder in Collaboration: Collected Essays on His Drama and Fiction. Edited by Jackson R. Bryer, Judith P. Hallett and Edyta K. Oczkowicz Newcastle Upon Tyne: Cambridge Scholars Publishing. Butler, Judith. 1990. Gender Trouble: Feminism and the Subversion of Identity. New York: Routledge.

Corrigan, Robert W. 1961. Thornton Wilder and the Tragic Sense of Life. Educational Theatre Journal 13: 167-73. [CrossRef]

Driver, Tom F. 1970. Romantic Quest and Modern Query: A History of Modern Theatre. New York: Delacorte Press.

Friedrich, Rainer. 1983. Drama and Religion. In Themes in Drama, No, 5: Drama and Religion. Edited by James Redmond. Cambridge: Cambridge UP.

Gadamer, Hans-Georg. 1989. Truth and Method, 2nd ed. Translated by Joel Weinsheimer, and Donald Marshall. New York: Crossroad.

Gates, Anita. 2002. Review of Our Town. New York Times, February 25, section E. 5.

Gillespie, Charles. 2019. Drama Alone is Credible: Hans Urs von Balthasar and the Interpretive Work of Theatre and Performance in Twentieth-Century Christian Thought. Charlottesville: University of Virginia dissertation.

Goffman, Erving. 1959. The Presentation of Self in Everyday Life. New York: Doubleday.

Goldstone, Richard H. 1975. Thornton Wilder: A Intimate Portrait. New York: Saturday Review Press.

59 The 2005/2008 revival directed by Buntrock, with digital scenery, did not show the machine directly; instead, colorful lights projected on the audience. See Brantley 2008, Arts section. 
Greenblatt, Stephen. 1998. Shakespearian Negotiations: The Circulation of Social Energy in Renaissance England. Berkeley: University of California Press.

Gussow, Mel. 1988. The Darker Shores of Thornton Wilder. New York Times, December 11, section H. 7, 37.

Harrison, Gilbert. 1983. The Enthusiast: A Life of Thornton Wilder. New Haven: Ticknor and Fields.

Healy, Patrick. 2010. Review of Our Town. New York Times, July 11, section AR. 1.

Herbert, Robert L. 1968. Neo-Impressionism. New York: Solomon R. Guggenheim Foundation.

Herbert, Robert, and Neil Harris. 2004. Seurat and the Making of La Grand Jatte. Chicago: Art Institute.

Isherwood, Christopher. 2009. Review of Our Town. New York Times, February 26, section C. 1.

Konkle, Lincoln. 2006. Thornton Wilder and the Puritan Narrative Tradition. Columbia: University of Missouri Press.

Konkle, Lincoln. 2018. Preparing the Way: Our Town and The Skin of Our Teeth as Proto-Postmodern Drama. In Thornton Wilder in Collaboration: Collected Essays on His Drama and Fiction. Edited by Jackson R. Bryer, Judith P. Hallett and Edyta K. Oczkowicz. Newcastle Upon Tyne: Cambridge Scholars Publishing, pp. 13-29.

Laster, Lori Ann. 2008. Welcome Back to Grover's Corners. American Theatre Magazine, May/June. 24-27.

McDonald, Macy. 2018. Thornton Wilder, American Existential Playwright: Our Town and Sartre's No Exit. In Thornton Wilder in Collaboration: Collected Essays on His Drama and Fiction. Edited by Jackson R. Bryer, Judith P. Hallett and Edyta K. Oczkowicz. Newcastle Upon Tyne: Cambridge Scholars Publishing, pp. 30-44.

McLaughlin, Robert. 2016. Stephen Sondheim and the Reinvention of the American Musical. Jackson: UP of Mississippi.

McNulty, Charles. 2017. Review of Our Town. Los Angeles Times. October 3. Available online: https: //www.latimes.com/entertainment/arts/la-et-cm-deaf-west-our-town-review-20171003-story.html (accessed on 18 February 2020).

Mudasir, Mufti. 2011. Language, Character and History in Postmodern Drama: Towards Formulating a Poetics. Criterion 2: 1-10.

Myers, Victoria. 2017. An Interview with Sarna Lapine. The Interval. March 28. Available online: https://www. theintervalny.com/interviews/2017/03/an-interview-with-sarna-lapine/ (accessed on 18 February 2020).

Niven, Penelope. 2012. Thornton Wilder: A Life. New York: HarperCollins.

Quigley, Austin E. 1985. The Modern Stage and Other Worlds. New York: Methuen.

Rich, Frank. 1988. Review of Our Town. New York Times, December 5, section C. 13.

Ricoeur, Paul. 1967. The Symbolism of Evil. Translated by Emerson Buchanan. Boston: Beacon.

Ricoeur, Paul. 1983. Time and Narrative. Translated by Kathleen McLaughlin, and Davis Pellauer. Chicago: University of Chicago Press, Vol. 1.

Scarry, Elaine. 1985. The Body in Pain: The Making and Unmaking of the World. New York: Oxford UP.

Secrest, Meryle. 1998. Stephen Sondheim: A Life. New York: Knopf.

Shapiro, Susan E. 1983. The Recovery of the Sacred: Hermeneutics and Theology after the Holocaust. Chicago: University of Chicago dissertation.

Shirley, Don. 2012. Review of Our Town. Los Angeles Stage Times Archive. January 23. Available online: https://thisstage.la/2012/01/a-former-simon-stimson-examines-broads-our-town-and-latc/ (accessed on 18 February 2020).

Sondheim, Stephen, and James Lapine. 1986. Sunday in the Park with George: A Musical. Music and lyrics by Stephen Sondheim. Edited by James Lapine. New York: Dodd and Mead.

Sondheim, Stephen. 2011. Look, I Made a Hat: Collected Lyrics (1981-2011) with Attendant Comments, Amplifications, Dogmas, Harangues, Digressions, Anecdotes and Miscellany. New York: Knopf.

States, Bert O. 1985. Great Reckonings in Little Rooms: On the Phenomenology of Theater. Berkeley: University of California Press.

Taylor, Mark C. 2004. Betraying Altizer. In Thinking through the Death of God: A Critical Companion to Thomas J. J. Altizer. Edited by Lissa McCollough and Brian Schroeder. Albany: State University of New York Press, pp. 11-29.

Tracy, David. 1975. Blessed Rage for Order: The New Pluralism in Theology. New York: Seabury.

Tracy, David. 1999. Fragments: The Spiritual Situation of Our Time. In God, the Gift, and Postmodernism. Edited by John D. Caputo and Michael J. Scranton. Bloomington: Indiana UP.

Turner, Victor. 1967. Betwixt and Between: The Liminal Period in Rites de Passage. In his The Forest of Symbols. Ithaca: Cornel UP, pp. 93-114.

Turner, Victor. 1974. Dramas, Fields, and Metaphors: Symbolic Action in Human Society. Ithaca: Cornell UP. 
Von Balthasar, Hans Urs. 1988. Theo-Drama: Theological Dramatic Theory. Translated by Graham Harrison. San Francisco: Ignatius Press, vol. 1, pp. 163-66.

Wilder, Thornton. 1957. Three Plays. New York: Harper and Row.

Zadan, Craig. 1986. Sondheim and Co, 2nd ed. New York: Harper and Row.

(C) 2020 by the author. Licensee MDPI, Basel, Switzerland. This article is an open access article distributed under the terms and conditions of the Creative Commons Attribution (CC BY) license (http://creativecommons.org/licenses/by/4.0/). 

Article

\title{
Bewitching Power: The Virtuosity of Gender in Dekker and Massinger's The Virgin Martyr
}

\section{Tom Fish}

Department of Theatre and Performance Studies, Kennesaw State University, Kennesaw, GA 30144, USA; tfish2@kennesaw.edu

Received: 16 September 2019; Accepted: 12 November 2019; Published: 14 November 2019

\begin{abstract}
This paper considers Thomas Dekker and Philip Massinger's play The Virgin Martyr (1622) in light of scientific notions of the female body circulating during the period to illustrate how the performance of martyrdom manifested a performance of gender virtuosity, elevating it to the status of the supernatural or divine. Like well-known female martyrs from the period, such as Anne Askew, the protagonist, Dorothea, takes on characteristically male attributes: she assumes the role of the soldier and defies scientific understanding of the female gender by sealing her phlegmatic "leaky" body and exuding divine heat that defies her cold, wet "nature". The theatricality of gender reversals in the play, from Dorothea and other characters, illustrates how the act of martyrdom could be interpreted not only as a miraculous performance, a "witness" to the divine, but one built on sensational, seemingly impossible performances of gender.
\end{abstract}

Keywords: martyrdom; gender; drama; early modern; Jacobean; masculinity; virgin

\section{Introduction: Lyke a Virgin—and the Armed Knight}

The title of this introduction borrows from the opening line of a widely circulated ballad of mid-sixteenth-century England, which reads, "Lyke as the armed knyght appoynted to the fielde with thys world wyll I fyght and fayth shall be my shielde". Although the song gained wide reception, with its lyrics published widely just the following year, only the select few in attendance at the ballad's one and only public performance would have recalled its tune. This performance would have taken place at Newgate, just outside London, on 16 June 1546, before the singer was carried off for a final performance at Smithfield. Those familiar with London's history will understand this cryptic anecdote: Smithfield was the most popular site for public executions during the period. The "knyght" in question is Anne Askew, one of the most well-known female martyrs of early modern England, and this ballad was allegedly the dramatic swan song she performed before she was burned at the stake for her steadfast commitment to her controversial religious beliefs. ${ }^{1}$ Later, in 1624, Askew's ballad, I am a Woman Poor and Blind, was entered in the Stationers' Register, a copyright-like practice that presumably occurred not long after. This ballad, as with the one from 1546, also illustrates a soldier-like fortitude embodied by a "poor and blind" female figure: "For such as the Scriptures saith that will gladly repent and follow thy word: Which I will not deny whilst I have breath, for Prison, fire, Faggot, nor fierce sword" (Beilin 1996, p. 197). These Askew martyr ballads draw on a Christian fortitude that recalls Paul's command in Ephesians to take up the "shield of faith" (6:11-18), while at the same time they draw on traditional masculine imagery, illustrating the performance's inherently paradoxical nature: the female

1 For the original ballad, see: "The Ballade whyche Anne Askewe made and sange whan she was in Newgate", stanzas 1-4, Bale (1547). For a modern version, with additional Askew writings, see Beilin (1996). 
martyr encases a characteristically masculine representation, the "armed knyght", within the idealized feminine form of the chaste virgin. ${ }^{2}$

This paper will turn to an early modern Jacobean play, Thomas Dekker and Philip Massinger's The Virgin Martyr, to explore how contradictory early modern conceptualizations of gender are played out on the gendered body to spectacular effect. The play, which was revived within a year of the printing of Askew's ballad in 1624, involves a series of characters, both virgin martyrs and male counterparts, challenging early modern scientific concepts. Their gender reversals, the masculinizing of the virgin and effeminizing of the soldier, defy perceived limitations of the male and female body. These theatrical displays, I will argue, perform a type "gender virtuosity", by which wonderous, affectively charged feats of gender defiance are played out, while highlighting the virtuous movement of the divine or the bewitching power of the supernatural. ${ }^{3}$

Dekker and Massinger's The Virgin Martyr was first licensed for performance at the Red Bull in October 1620 , the play being published in early $1622 .{ }^{4}$ The play is the only known collaboration of Massinger, known primary for his Caroline dramas, and the elder, Elizabethan playwright Dekker. Set in Caesarea in the fourth century A.D., its plot is drawn from the tenth and final persecution of the Christians in the reign of Diocletian. The play seems to have been popular during its day and age; the published title claims that it "hath bin divers times publickely acted with great applause", and though this could be a mere marketing tactic, its four quarto publications and its later reintroduction on the Restoration stage testify to the play's acclaim (Dekker and Massinger 1958, p. 365). While the appearance of a saint's play might seem strange within post-Reformation London, the Red Bull audiences of Clerkenwell in north London were known for their affinity for medieval performance styles during the Jacobean period. ${ }^{5}$ Anne Lancashire has also detailed how the London Clerkenwell play (or Skinners' Well play) marks a roughly 400-year tradition of multi-day biblical performance in in region of the Red Bull that dated up until the mid to late sixteenth century. ${ }^{6}$

Thomas Moretti presents another cogent account for the play's appearance and resounding popularity. His article explores how the production carefully balances its religious sentiment to appeal- "via media" - to the widest cross-section of Jacobean London, excluding only religious extremists on either end (Moretti 2014). The spectacular effects of gender, which this article will detail, provide a complimentary reason for the play's popularity when considered in light of contemporary theories of affect in performance. Nicholas Ridout's Stage Frights describes the commercial theatre as a virtual affect-machine (Ridout 2006). The mechanism of this theatrical machinery, its "tools", are what Erin Hurley calls "feeling-technology", which collectively work to satisfy theatre's central preoccupation: "making, managing, and moving feeling in all its types (affect, emotions, moods, sensations) in a publicly observable display that is sold to an audience for a wage" (Hurley 2010, p. 9). The Red Bull was notoriously known for its "drum and trumpet" repertoire and low-brow appeal. Their audience members were often critiqued by early modern playwrights for their lack of sophisticated taste. ${ }^{7}$ The action-packed gender reversals in the play, which I will later describe, frontload wonder, disgust, even violence and humor to help drive its popular appeal. Dekker and Massinger's version of

2 Thomas Nashe makes reference to "the ballet of Anne Askew" by quoting the first line in Have With You to Saffron Walden in 1596.

3 The idea of a gender virtuosity, although a stretch from its usual contexts and associations with musical performance, looks to capture both a theatrical quality and an extraordinary nature.

4 A new scene was licensed for The Virgin Martyr in 1624, indicating a revival of the work, probably by a different, as yet unknown, company.

5 Examples include: Rowley's A Shoemaker Gentleman (1618), Shirley's The Martyred Soldier (1619) and The Two Noble Ladies (c. 1619-22), see Munro (2006).

6 While few records exist, for a detailed analysis of these performances, see Lancashire (2006).

7 Red Bull had a low number of published plays and the ones that were published often failed to credit the name of the theatre, which was common practice during the time. The overall low number of published plays could suggest a more illiterate audience at Red Bull. Not acknowledging the theatre in publication could be a conscientious attempt to avoid association with the illegitimate theatre, but it could also be evidence that the play moved theatres, see Griffith (2013, pp. 255-56). For more on the company's reputation, see Munro (2006). 
Dorothea's legend can, following Moretti, appeal to a large base with moderate religious views, yet its popularity could be driven, as well, by its reversals of gender, which offer spectacular effects/affects, while failing to challenge normative ideologies.

Since the plot of the play remains largely unknown to contemporary readers, a summary may serve useful. The governor's son, the soldier Antoninus, has fallen in love with the virgin Dorothea, although he has already been betrothed to another, the Emperor Diocletian's daughter, Artemia. In despair, Antoninus attempts to court Dorothea, professing his love for her, yet the virgin remains steadfast against his advances. During this exchange, however, the couple is spied on by Theophilus, Rome's chief persecutor of heretics, who consequently learns of Dorothea's Christian faith and has her arrested. To convert her to Paganism, Theophilus calls upon his two daughters to persuade her: this attempt backfires as Dorothea converts the daughters to Christianity instead. When Theophilus orders the virgin to be tortured and raped, she remains protected by mystical powers and is unable to be harmed. While this is taking place, Antoninus falls ill from unknown sources, and when Dorothea is ultimately beheaded, he dies as well. The play's fifth act traces the later conversion of Theophilus (Greek = "lover of God") to Christianity influenced by Dorothea and her extravagant reappearance from beyond the grave.

Julia Gasper's scholarship has pinpointed several potential sources that Dekker and Massinger could have used in crafting their plot, including Foxe's Actes and Monuments, as well as a few Catholic martyrologies, such as Caxton's translation of The Golden Legend and Edward Kinesman's translation of Alfonso Villegas's Flos Sanctorum. ${ }^{8}$ The legends of two relatively obscure fourth-century martyrs, St Agnes and St Dorothy, were conflated to create the central martyr character, Dorothea. ${ }^{9}$ The playwrights hereby allowed themselves freedom of construction, not limiting themselves to maintaining historical accuracy built around a single, more recognizable saint. The aptly named Dorothea (derived from the Greek doron or "gift" and thea "of God") becomes a clearly idealized character based on but not limited by these historical women. By considering the issue of adaptation in The Virgin Martyr, Susannah Monta has illustrated how the play alters its martyrological sources to highlight religious competition, consequently "intensifying the resistance of the female martyr so that her purity may facilitate the separation of true from false religion" (Monta 2005, p. 196). Dorothea's gender reversals demonstrate this "intensifying resistance" and purity, which as this paper will later explain, is also highlighted by several of the male characters and their gender conversions.

Much of the available scholarship on the play addresses the play's hagiographical or martyrological function, while often arguing for the play as either Catholic or Protestant propaganda. ${ }^{10}$ Jane Degenhardt and Holly Pickett's scholarship, however, has operated on the assumption that "critical interpretations that stress only [the play's] relationship to England's Catholic-Protestant controversy seem inadequate", stressing instead the contemporary political relevance of the play in the 1620s; Degenhardt relates the play to the contemporary threat of Islam, whereas Pickett illustrates the play's ability to comment on the inherent theatrical nature of conversion during the period. ${ }^{11}$ Monta argues the play uses allegory to veil criticism of James I's foreign policy in the early years of the Thirty Years' War, which some Protestants believed accommodated Catholic aggression (Monta 2005, p. 194).

Although The Virgin Martyr is in some ways untraditional in its appearance as the "only post-Reformation saint's play in post-Reformation London", it is rather traditional in the way that it plays off of the presumably weaker female sex in order to heighten its power as martyrology (Logan and Smith 1978, p. 99). Monta contextualizes Dorothea among the lineage of early modern female martyrs, observing that the martyrs of lower social status became valuable partly because of

\footnotetext{
For details on the play's sources, see Gasper (1991).

For more on Saint Agnes and Saint Dorothy, see Winstead (2000).

10 For Louise George Clubb's argument that the play serves as Catholic propaganda, see Clubb (1964). More recently, Julia Gaspar and Susannah Monta have each argued for the play as Protestant propaganda. See Gasper (1991) and Monta (2005).

11 For more on the play's contemporary political relevance, see Pickett (2009) and Degenhardt (2006), for specific quote, p. 93.
} 
their violation of expectations, thereby making their testimony even more powerful. Quoting from Foxe and Kinesman, Monta shows how female martyrs, "frayle by nature", are praised for acting "manfully", allowing the female martyrs to evince sanctity, since "only God could inspire such constancy and zeal in otherwise unremarkable people" (Monta 2005, p. 197). This essay adheres to Degenhardt's advice to explore beyond the Catholic/Protestant debates over the play, while building upon Monta's previous investigation. It looks to demonstrate how gender transformation, of both virgin martyrs and their male counterparts, offers virtuosic theatrical events that bear "witness" to spiritual transformation. ${ }^{12}$

\section{Onward Christian Soldiers}

The play's reversal of gender is readily apparent in the martial terms used to describe the characters. Like the image of Askew taking up arms for battle, throughout The Virgin Martyr pagan and Christian faiths are posed in stark opposition, as two armed forces locked in battle, with conversion representing a successful military strike. The play expands on its martyrological sources to establish the Roman religion as a threatening religious system that idealizes masculinity and stoicism (Monta 2005, p. 201). The character Harpax, secretary to Theophilus, uses terms of warfare to depict the threat of Dorothea's religious fervor: "a Firmament of Clouds being fild with Joves Artillery, shot downe at once to pash your Gods in peeces, cannot give with all those Thunderbolts so deeps a blow to the Religion there, and Pagan lore as this" (II.ii.58), and at the climactic moment at the end of the play, occurring only moments after his conversion, Theophilus's final words before his martyrdom read: "I die a souldier in the Christian warres" (V.ii.233). ${ }^{13}$ The heroic martyr figure exists in-but is also defined by-a landscape of war-like imagery, which creates an ongoing drive to be inwardly armed against external spiritual forces. ${ }^{14}$

The female martyrs in the play are also described by masculine, martial language. By combining the soldier image with an idealized female form, Dekker and Massinger draw upon a motif of Roman stoicism. Set in fourth-century Caesarea, the story lends itself to Roman allusions that might not otherwise fit in Jacobean London. Monta has argued that this helped to strengthen the play's political resonance. ${ }^{15}$ Theophilus's virgin daughters, Calista and Christeta, "sufferd with Roman constancy" when they were splayed on the rack and fell victim to the hangman's whip (I.i.177). Dorothea similarly evinces a Roman stoicism in her lack of fear in the sight of death and forthcoming torture: "The visage of a hangman frights not me; The sights of whips, rackes, gibbets, axes, fires are scaffoldings, by which my soule climbes up to Eternall habitation" (II.iii.166). Her stoic demeanor is consistent with accounts of female martyrs in Foxe's Book of Martyrs by which "God masculinizes his elect" (Moretti 2014, p. 260).

The play contrasts the female martyr's soldierly disposition with the effeminacy of a real soldier, Antoninus. The strongest example of this is when he develops a mysterious lovesick illness and lies in bed alone crying out in torment for Dorothea to "deliver him" from his pain. His father and friend, making jest about his ill-fitting behavior, claim Antoninus can only be cured if a midwife will "deliver him" (IV.i.20). The sick soldier is given the opportunity to claim Dorothea's virginity, which is described as the best remedy for his illness, yet he is unable to go through with the act. His father chastises him, "a souldier, and stand fumbling so", heightening the contradiction between Antoninus's

12 I use the word "martyr" in terms of its Greek origin meaning "to witness".

13 This and all other citations from the play are drawn from The Dramatic Works of Thomas Dekker, v. 3, edited by Fredson Bowers, see Dekker and Massinger (1958).

14 The view of Christian faith in martial terms falls into the reading strategies of the early modern audience, a group already primed to view spiritual forces of good and evil as in direct, continual opposition. Brad Gregory's Salvation at Stake highlights these reading strategies of the early modern audience, and makes a valuable point that the symbolic value of the martyr figure could actually be more real to the early modern interpretative community than their temporal reality, see Gregory (2001, p. 10).

15 Monta argues that the play's work as political allegory could in part be based on the easy connection between classical Rome and the "newly revived Roman (and, in Ferdinand's hands, threateningly Catholic) Empire on the continent", see Monta (2005, p. 199). 
militant strength, role as masculine soldier and "penetrator" and his inability to go through with the sexual act (IV.i.98). ${ }^{16}$

Significantly, Dekker and Massinger use early modern rhetoric of the body to conceptualize Antoninus's reversal. The father ridicules the lovesick soldier further, explaining the emasculation of his son by specifically drawing upon the Galenic model and classical humoral theory:

Cold, Phlegmatike Bastard, th'art no brat of mine,

One sparke of me, when I had heate like thine

By this had made a Bonfire: a tempting whore

(For whom th'art mad) thrust even into thine armes,

And standst thou puling!

(IV.i.111)

Early modern scientific accounts, such as those detailed by Thomas Laqueur and Gail Kern Paster, emphasize the porous, penetrable, cold, and essentially weaker nature of the female body. Laqueur's study of gender and anatomy identifies a one-sex model of gender, largely driven by heat in the body. He describes this model as follows:

It is to begin with, the sign of perfection, of one's place in the hierarchical great chain of being. Humans are the most perfect of animals, and men are more perfect than women by reason of their 'excess of heat'. Men and women are, in this model, not different in kind but in the configuration of their organs; the male is a hotter version of the female, or to use the teleologically more appropriate order, the female is the cooler, less perfect version of the male.

(Laqueur 1986, p. 5)

The female sex is characterized as inadequate or lacking, with heat - the perfecting agent-typically being bestowed upon the male, the dominant sex. Antoninus's father refers to the coldness of his son, equating this with weakness. He describes how "when I had heate like thine", presumably a reference to his own virile younger years, "one sparke" would create a bonfire. This claims a fiery libido for himself that-with the one-sex model-is associated with the male sex.

In her study "The Unbearable Coldness of Female Being", Gail Kern Paster questions the teleology of the Galenic model, yet confirms the importance of heat to the conceptualization of early modern gender. She takes into account the classical humoral theory of the four temperamental categories (melancholic, choleric, sanguine, phlegmatic), which were based on an excess or lack of the four bodily fluids: blood, yellow bile, black bile, and phlegm. Paster recognizes the key "ideological blindspots" built into a model that "inscribed the sign of woman as normative in only one of its four categories-the cold, clammy, humor dominated by phlegm" (Paster 1998, p. 422). By incorporating humoral and Galenic rhetoric, Sapritius describes his son as taking on a phlegmatic disposition that lacks even one spark of heat, characterizing the soldier's transition as not mere lovesickness, but as an emasculation of that challenges natural order. The language of the body used in the play offers a way to both describe and dramatize spiritual transformations via gender transformation, as well as the movement of power along hierarchical lines.

Dekker and Massinger also present a miraculous reversal of gender through the theatricalization of Dorothea's "shield of faith" and the display of her impenetrability on stage. Paster observes that the female was characterized not only as cold in early modern conceptualizations but also as a leaky

16 Similarly, in Dekker's The Honest Whore, Part II (coauthored with Middleton), the character Hippolito is subject to fits of love sickness resulting in extremely melancholy (see Comensoli 1989). Additionally, Massinger's The Picture (1629) shows a striking reversal of gender as sexual indulgence emasculates the King, allowing him to take on a "disturbingly subservient role to the queen", see Hila $(2016$, p. 72$)$. 
vessel (Paster 1998, p. 420). ${ }^{17}$ Dorothea defies the preconceived notions of the soft, porous, and easily penetrable female body; the virgin becomes solid and impenetrable through supernatural means, creating a theatrical representation of supernatural proportions, framed here as a divine agency that can be harnessed to empower the female sex. During her climactic torture, and despite incessant beatings, Dorothea remains unscathed:

\begin{abstract}
SAP. Strike.
Strike at her: Angelo kneeling holds her fast.

THEO. Beate out her brains-

DOR. Receive me you bright Angels

SAP. Faster slaves.

HIR. O mine armes, I cannot lift 'em to my head.

DOR. Joy above joys, are my tormentors wearie

In torturing me, and in my sufferings

I fainting in no limbe: tyrants strike home

And feast your fury full.
\end{abstract}

SPUN. Faster: I am out of breath I'am sure: if I were to beate a bucke, I can strike no harder.

The virgin martyr accepts her fate in a characteristically stoic fashion; rather than fighting back, she turns to the heavens and cries to the angels to receive her. The beating becomes a physical manifestation of her spiritual fortitude: Dorothea is protected by a literal force field of her own faith, assisted by her guardian angel, Angelo (the allegorical "Angel-o"), who "holds her fast". Dorothea's body, and her beauty, is unharmed, despite the efforts of the punishers who exhaust themselves in their attempts to beat her. ${ }^{18}$ The pagans take turns trying to attack her to no avail, marveling that, "these bats have power downe to fell gyants, yet her skin is not scar'd" (IV.ii.105). This personifies Katharine Eisaman Maus' account of Renaissance women whose "moral worth was inevitably involved with the fate of her vulnerable body" (Maus 1996, p. 205).

Additional attempts to "penetrate" Dorothea's body are also thwarted by supernatural means, further representing a defiance of the female body. When Antoninus is unwilling to rape the young virgin, his father, furious, calls upon a slave to do the deed to humiliate his feeble son further. The slave first has his masculinity questioned to ensure his readiness to claim Dorothea's virginity. In a comic scene that would have resonated with London's Clerkenwell audience, the slave's British heritage is said to make him more than up to the task, since "of all Nations our Romane swords ever conquer'd, none comes neere the Brittaine for true whooring" (IV.i.133). In a fiery speech, the slave describes the extreme lengths he would go to in order to gain his freedom, which includes fighting naked with a lion, shaking off his chains, and jumping off a rock ten pyramids high in order to battle to the death (IV.i.135). He clearly describes for the audience his extreme masculine potency and unquenchable desire for freedom, and yet when he is told he will gain freedom by raping Dorothea, in a surprising turn, the slave scorns to do it. The play heightens his presumed masculinity, only to thwart it, reflecting another uncanny protection of Dorothea by a supernatural source. The virgin martyr credits the slave's complete reversal to the work of "that Power supernall on whom waites my soule, is Captaine ore my chastity" (IV.i.162). Once again, wondrous gender reversal marks a performance of the divine, while also appealing to an audience preoccupied with what G.E. Bentley describes as "violence and vulgarity" (quoted in Munro 2006, p. 100).

The play enacts a gender virtuosity of supernatural proportions, built off popular early modern concepts of the weak, penetrable female and the strong, "penetrating" male. Dorothea's impenetrability

17 For more of Paster's analysis on the female as "leaky" vessel, see Paster (1993).

18 The inclusion of various types of miraculous displays was common in early modern female martyrologies. Several accounts of Askew's martyrdom, for example, remark on the "divine sign of thunder", see Beilin (1996, p. xxxvii). 
and soldier-like fortitude creates a stark contrast to the emasculation of the male figures in the play, who are particularly emblematic of machismo and a masculine "heat". The "soldier" is redefined as a performative, with the outward appearance of the imposing military man proving less powerful than the inwardly soldierly disposition acquired through faith. Consequently, power is dramatized through gender reversals, with the spiritual or supernatural trumping the outward display of arms and steel.

\section{Divine Fire, Holy Tears, and Celestial Rays}

Dekker and Massinger find further ways to theatricalize the androgynous female martyr defying her bodily limitations in physically "impossible" ways. One way is how Dorothea claims the "fire" or "heat" typically associated with male agency. When Harpax speaks of Dorothea and Antoninus's possible relationship, it is a "fire of love", driven by sexual desire, contrasting with divine heat (II.ii.50). Harpax defines women as cold, insisting that they rely on a man through the passionate "fire of love" for access to heat. However, Dorothea, as a virgin, refuses this source, relying instead on holy fire for heat that has an atemporal source. Within the play, this spiritual fire is also described as the means by which she defies penetration (in multiple senses). Antoninus specifically warns her to "quench not out the holy fires within you" to avoid death during her persecution (II.iii.190).

Dekker and Massinger also use heat to dramatize conversion through gender transformations. This technique is used for Dorothea, the other converted female characters, as well as several males. Antoninus describes this phenomenon, as he gains heat, or the more "perfect" condition, in the moment of his conversion to the Christian faith: "I feele a holy fire, that yeelds a comfortable heate within me. I am quite alterd from the thing I was" (IV.iii.160). By this stage, Antoninus has already transformed from the masculine "hot" soldier to the "cold" and "phlegmatic" ill-struck lover. Divine heat offers the miraculous cure to his early gender reversal, by which he previously lost power. Similarly, following his own conversion, Theophilus redefines fire not as a means of torture, but as a means of purification:

I stand

Accomptable for thousand Christians deaths,

And were it possible that I could die

A day for every one, then live againe

To be againe tormented, twere to me

An easie pennance, and I should passe through

A gentle clensing fire.

(V.ii.178)

This newfound stoicism parallels Dorothea's use of the hangman's tools as "scaffoldings by which my soul climbs up to an eternal habitation" (II.iii.166). The blaze at the scaffold, converted into a "gentle clensing fire", becomes a way to theatricalize spiritual or supernatural conversion.

Similarly, Dekker and Massinger present tears, associated with the "leaky" body, as the potential by-product of a holy purification as well. In the first scene of the play, Theophilus establishes the common understanding of "womanish teares", as a derogatory sign of feminine weakness (I.i.59). Yet when tears are placed within the discourse of Christian martyrdom later in the play, their meaning is altered; as with the sensation of the "holy fire", they become a theatrical representation of spiritual transformation. When Dorothea converts Theophilus's daughters to Christianity, tears become a divine representation of the spirit:

You weepe,

Oh tis a heavenly showre, celestiall balme

To cure your wounded conscience, let it fall,

Fall thick upon it, and when that is spent,

Il helpe it with another of my teares.

And, may your true repentance prove the child

Of my true sorrow, never mother had 
A birth so happy.

(III.i.192)

Tears become an additional way to perform divine purification: a "celestial balm". They also offer a source of rebirth for the virgin. She becomes a surrogate mother figure, and her tears recall the popular iconic representation of the crying Virgin Mary. Just as the hangman's tools are reframed as a scaffolding to heaven, tears as a sign of weakness are similarly inverted: the display of feminine weakness becomes a sign of spiritual—and masculine—strength.

Angelo tells Dorothea that if she remains strong in her faith she will wear sunbeams on her head as a sign of victory (II.iii.194). The sunbeams, a spiritual crown, become representational not only of divine light but also divine heat emanating from the virgin, characteristic of historic martyrs from the period. Dekker and Massinger can theatricalize the resurrection of Dorothea in a triumphant return to the stage at the end of the play, wearing such a radiant crown. In this epiphany, she is described in the original stage direction as appearing: "in a white robe, crownes upon her robe, a Crowne upon her head" (V.ii.218). She represents a complete embodiment of divine victory, dressed all in white, and covered with crowns literally from head to toe.

To return, briefly, to Anne Askew, likely the most famous virgin martyr from the period, the title page of John Bale's testimony of her trial, The first examinacyon of Anne Askewe (1546), offers a depiction of what the appearance of the virgin martyr in her literal and figurative glory might have looked like. As with Dorothea, there are sunbeams, a celestial halo, emanating from around her head and they both appear in white robe to reflect their purity (see Figure 1). Askew's divine victory is further represented by her palm branch and the proud display of the holy scriptures as her only weapon.

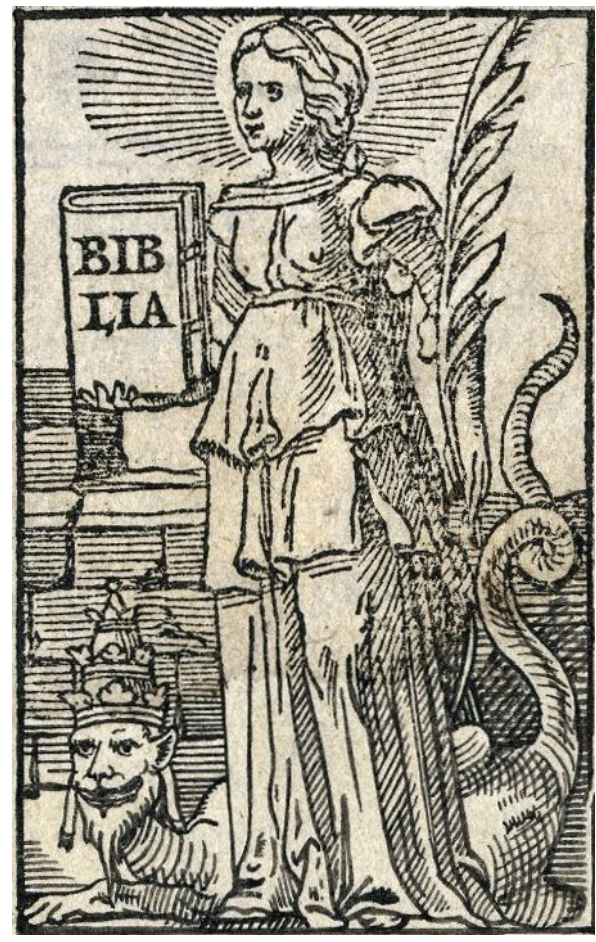

Figure 1. Image from the title page of John Bale's edition of The first examinacyon of Anne Askewe (1546). Female martyrs, such as Askew and Dorothea, were often associated with this type of spiritual crown. The antichrist, commonly depicted as a dragon, sits at Askew's feet. His defeat is clear by his pope's tiara and submissive stance. Photo credited: Huntington Library, San Marino, California.

Dorothea also represents an idealized beauty and a serene response comparable to the image of Askew. The virgin martyr's beautiful appearance, despite her torment and physical assault, offers a further way to theatricalize the miraculous. Dorothea's resurrected body, as with Askew's, takes on a 
beautiful and unscathed form, rather than a martyred, seemingly grotesque body. Beauty becomes a prerequisite for the virgin martyr; in the opening of the play, Theophilus's daughters are described as "faire ones, exceeding faire ones" (I.i.165) as well as "beauteous virgins" (I.i.195). The two daughters, it is discovered, previously underwent severe physical punishment in a successful attempt to convert them to Paganism. Realistically, these daughters would have been scarred and battered, with their bodies dismembered, yet they remain whole and seemingly unscathed despite the severe abuses they endured on the rack. ${ }^{19}$ The daughters's perfected appearances sets them up as exemplary figures for their conversion to Christianity and subsequent martyrdom. Similarly, Dorothea not only retains beauty during her arduous torture at the stake but paradoxically gains attractiveness, with Theophilus commenting that "her face has more bewitching beauty than before" (IV.ii.95). ${ }^{20}$

The play further theatricalizes the miraculous through Dorothea's serene emotional response and even joy in the face of brutality. The emotional life of Dorothea, strengthened by her spiritual fortitude, is a clear contrast to notions of the overly emotional early modern female. Theophilus comments that not only does her face have more "bewitching power", "it smiles". (IV.ii.96). Later, when she is facing the scaffold, Antoninus remarks again that, "she smiles, unmov'd" (IV.iii.66). ${ }^{21}$ Her surprising affective response becomes a further reflection of the supernatural or miraculous at work. Relating back to Askew's ballad from the introduction, similarly, the act of singing marks an act of triumph. Both martyrs, through two different mediums, the theatre and the ballad, can be remembered for rejoicing in the face of persecution. Conversely, it is the emasculated soldier, Antoninus, who displays morose and "effeminate" emotions by falling into a melancholic sickness when denied Dorothea's love.

Dorothea also provides an example of how women can and even should oppose their "natural" temperament by assuming a traditionally masculine anger. When Theophilus's daughters attempt to convert the virgin martyr to the pagan faith, she has an outbreak of fury that runs in opposition to her own typically serene emotional response and "maidenly" behavior. She justifies women acting against their own emotional disposition in the name of religion when she chastises Calista and Christeta:

DOR. Have you not cloven feete; are you not divels?

Dare any say so much, or dare I heare it,

Without a vertuous and religious anger?

Now to put on a Virgin modesty,

Or maiden silence, when his power is question'd

That is omnipotent, were a greater crime,

Then in a bad cause to be impudent.

Dorothea forges a space by which anger in the name of the Christian faith is more than acceptable: it is a necessary response. A "vertuous and religious anger" are accessible to women as an extension of divine power and moral goodness. Dorothea's speech suggests a brazen passion as she reprimands the women for their "maiden silence", which would likely be embodied as well in performance. The other martyr women learn from Dorothea's lesson, demonstrating an outbreak of their own virtuous anger in the following scene. When they are called to kneel and make vows to Jupiter, the stage direction reads, "they both spit at the Image, throw it downe, and spurne it" (III.ii.53). Consequently, they too

19 This correlates with Katji Altpeter-Jones's findings that “didactically oriented texts that attempt to teach appropriate gender role behavior focus more consistently-and for obvious reasons-on gestures of female submission and a portrayal of immutable, closed bodies", see Altpeter-Jones (2008, p. 44).

20 Karen Bramford in her analysis of sexual violence in Jacobean drama uses this play as an example of the "pornographic emphasis on the body as the object of male anger and desire", see Bramford (2000, p. 46), Bramford emphasizes how the body must remain beautiful and desirable to provoke arousal (pp. 47-48).

21 Positive or calm emotional displays in the face of gruesome persecution are also cited amongst the accounts of actual female martyrs during the period, with some crediting this disposition to the Holy Spirit, whereas others see it as possession by a "merry devil", see Gregory (2001, p. 338). 
theatricalize a transgressive emotional response, a performance of gender virtuosity, that runs contrary to the modest virgin prototype.

\section{Gender and the Martyr Paradox}

Dekker and Massinger illustrate how a dual reception is formed around the virgin martyr's gender transformation, resulting in two concurrent opposite interpretations: the virgin as martyr and witch. Consequently, Monta has argued that the play longs nostalgically for a "a searingly clear conflict between right religion and damnable falsehood" (Monta 2005, p. 195). The playwrights show how the performance of gender can work as a theatrical tool to strengthen-if not make-a persuasive and affectively engaging martyr legend. There may even be ways by which the play's audience members could have gained critical insight, allowing them to view and understand martyrdom as inherently an act of interpretation. ${ }^{22}$ Through the theatrical medium, the audience is able to see the resurrection of Dorothea's body made manifest and hear the extraordinary "celestial music" that begins to play at Dorothea's death. ${ }^{23}$ Yet the audience sees different characters perceive this moment in contrasting ways: whereas some hear "heavenly music", others hear "illusions of the devil, wrought by some witch of her religion, that fain would make her death a miracle" (IV.iii.189). The simultaneous process by which both the martyr and the witch are concurrently made is called into question. ${ }^{24}$ Significantly, in both cases, the female martyr's power is inherently paradoxical: it is either characterized as witchcraft or divine spirit, but what remains clear is that the virgin's agency, her source of "heat", is never quite her own.

Through the martyr/witch dichotomy, the play offers insight into the relationship between the performance of female martyrdom and early modern patriarchy. Significantly, Dorothea is first characterized as a witch not simply for her display of supernatural powers, but because of her ability to control the men around her and resist control herself. Her defiance of domestic hierarchies and gender norms is a primary factor in her demise, and not solely her transgressive religious beliefs. The impetus for critical attack against Dorothea stems from the fact she is not viewed as the ideal wife for Antoninus. In the opening scene, the emperor's beautiful daughter Artemia is given the opportunity to select her own husband. It is decided before she picks her partner that any man she chooses will have to be beneath her rank, with some potential suitors uttering prayers to "Gods of Love" in the hope of being selected (I.i.312). When she selects Antoninus, who shies away and blushes at her advances, a precursor of his emasculation, he is admonished by his father to "welcome, foole, thy fortune, stand like a blocke when such an angell courts thee!" (I.i.320). This fortune is quite literal since Artemia is the daughter of the emperor, making her undoubtedly one of the most powerful and wealthy women of Caesarea. This union would raise Antoninus's class, turning him from a subject into a lord, while even making it Artemia's duty to honor him (I.i.338). Antoninus's friend Macrinus tries to make sense of his lack of interest in the emperor's daughter, but Antoninus has defiantly bestowed his love on Dorothea already (I.i.413). Consequently, the virgin is formulated from the opening of the play as enemy primarily because of her ability to threaten the social system and thwart Antoninus's economic, political, and social aspirations. The driving force behind the later witch hunt that develops against her begins before Dorothea's religious beliefs are even known. Similarly, Anne Askew's Protestant beliefs, for example, officially characterized her as a heretic, but this cannot be easily separated from her defiance of proper gender roles. In particular, Anne was canonized in her maiden name Askew, rather

22 Myhill argues that this appears in the shift of the play's genre, which turns from a drama towards a more traditional saint's play in the final two acts, moving the play from more representational to more presentational, see Myhill (2004, p. 25).

23 Moretti reads the final line at Dorothea's death, "she lived a virgin, and a virgin dies", as a double entendre that eludes to mystical sexual union with God, an abrupt return to her chaste female body in death, see Moretti (2014, pp. 262-63).

24 Marla Carlson illustrates how the virgin martyr's body occupies a dialogical position, "silent and obedient as the church and society would have her but also a figure for the mystic who transgresses and exceeds those limits through her embodied imitation of the Passion", see Carlson (2010, p. 164). 
than her married name Kyme, which reflects a transgressive denial of the patriarchal social order of early modern England. ${ }^{25}$

Antoninus's immediate lack of interest in marrying the emperor's daughter drives his father, Sapritius, into a fury. His father, of course, has much to gain from this strategic union. Sapritius develops into the play's biggest critic of Dorothea, largely because of her "bewitching" powers over his son:

\author{
She's a Witch, \\ A sorceresse Theophilus, my sonne \\ Is charm'd by her enticing eyes, and like \\ An image made of waxe, her beames of beauty \\ Melt him to nothing; all my hopes in him, \\ And all his gotten honours, finde their grave \\ In his strange dotage on her.
}

He characterizes Dorothea, once again, as harnessing defiant powers, exemplified by "beames of beauty", a fire that will "melt him to nothing" and emasculate his soldier-son. Here the characteristic "beams" of the martyr, a signifier of attractiveness, is strategically reframed. Sapritius illustrates the dual reception of the virgin martyr/witch. Antoninus's "strange dotage" on Dorothea defies logic; her transgressive sway over Antoninus makes him act against his masculine nature and his own economic best interest.

\section{Conclusions}

Dekker and Massinger show how martyrdom, as a performance act, uses the gendered body to represent spiritual shifts, conversions, and miraculous feats. Within the play, rhetoric of the body contrast Dorothea's subversive inner-masculine nature with the complete emasculation of surrounding male figures. She takes on characteristically male attributes by assuming the role of the soldier, sealing her "leaky body", and exuding heat and sun beams that defy scientific understanding of her sex. Elizabeth Castelli describes in Martyrdom and Memory how gender plays a particularly important role in martyrdom since it "has to do foundationally with competing ideas about the character and legitimacy of different systems of power", with gender operating not only as a way of perceiving sexual difference but also as a way of signifying relationships of power (Castelli 2004, p. 4 ) ${ }^{26}$ Since the female martyr creates a depiction of a female figure that opposes the general presumptions of woman's physiological/psychological nature, the figure could become a stronger example of spiritual fortitude than her male counterpart. At the same time, Dekker and Massinger's play suggests a further reason the actual performance of female martyrdom might have been such an effective rhetorical tool: her ability to defy her own body in "impossible" ways, reversing "feminine weakness" into "masculine strength", could turn the act of public execution itself into a display of the supernatural or, for some, the miraculous.

Dorothea represents a paradoxical figure on multiple fronts. Her access to agency and power, as illustrated through the performance of various "divine" reversals, are framed outside the possibilities of the female sex, reflecting a power beyond herself, whether interpreted as evil or divine. Additionally, what we know of the female martyr's swan song has always been posthumously forged, for it is through death that this idealized, androgynous female martyr is ironically made and unmade; it is only through death that her legend, one that defies temporal explanation within early modern

25 Monta points out that Askew's martyrologists tended to downplay the fact that she left her husband for fear this would cause criticism (Monta 2005, p. 207).

26 Castelli draws the relationship of gender and systems of power from Joan Wallach Scott, Gender and the Politics of History, see Scott (1988, pp. 28-50). 
conceptualizations, is able to "exist". Of course, on stage in The Virgin Martyr, Dorothea's transgressive power was not even embodied by a female, after all, but by the representation of a boy player, created by male playwrights, drawing upon martyrologies written by men.

During the early modern era, as Monta claims, "a martyr's religion, not his/her gender, was the foundational analytical category" (Monta 2005, p. 197). Certainly, the road that leads the female martyr to the grave entwines the controversial implications of her faith system with the implications of her gender and her defiance of gender norms. However, The Virgin Martyr foregrounds how the performance of gender and, moreover, the virtuosic performance of gender reversal, could raise the act of martyrdom to spectacular theatrical heights.

Funding: This research received no external funding.

Conflicts of Interest: The author declares no conflict of interest.

\section{References}

Altpeter-Jones, Katji. 2008. Inscribing Gender of the Early Modern Body: Marital Violence in German Texts of the Fifteenth and Sixteenth Century. Early Modern Women Journal 3: 27-60.

Bale, John. 1547. The Lattre Examinacyon of Anne Askewe, Latelye Martyred in Smythfelde, by the Wycked Synagoge of Antichrist, with the Elucydacyon of Johan Bale. Wesel: Dirik van der Straten.

Beilin, Elaine, ed. 1996. The Examinations of Anne Askew. Oxford: Oxford University Press.

Bramford, Karen. 2000. Sexual Violence on the Jacobean Stage. New York: St. Martin's Press.

Carlson, Marla. 2010. Performing Bodies in Pain: Medieval and Post-Modern Martyrs, Mystics, and Artists. New York: Palgrave Macmillan.

Castelli, Elizabeth. 2004. Martyrdom and Memory: Early Christian Culture Making. New York: Columbia University Press.

Clubb, Louise George. 1964. The Virgin Martyr and the Tragedia Sacra. Renaissance Drama 7: 103-26. [CrossRef]

Comensoli, Viviana. 1989. Gender and Eloquence in Dekker's The Honest Whore, Part II. English Studies in Canada 15: 249-62. [CrossRef]

Degenhardt, Jane. 2006. Catholic Martyrdom in Dekker and Massinger's The Virgin Martyr. ELH 73: 83-117. [CrossRef]

Dekker, Thomas, and Philip Massinger. 1958. The Virgin Martyr in The Dramatic Works of Thomas Dekker. Edited by Fredson Bowers. Cambridge: Cambridge University Press, vol. 3.

Gasper, Julia. 1991. The Sources of The Virgin Martyr. Review of English Studies 42: 17-31. [CrossRef]

Gregory, Brad. 2001. Salvation at Stake. Cambridge: Harvard University Press.

Griffith, Eva. 2013. A Jacobean Company and Its Playhouse: The Queen's Servants at the Red Bull Theatre. Cambridge: Cambridge University Press.

Hila, Marina. 2016. 'To Heighten Your Desire': Sexual Politics in Massinger's The Picture (1629). Cahier Élisabéthains 92: 68-81. [CrossRef]

Hurley, Erin. 2010. Theatre \& Feeling. New York: Palgrave Macmillan.

Lancashire, Anne. 2006. Multi-day Performance and the London Clerkenwell. Early Theatre 9: 114-29.

Laqueur, Thomas. 1986. Orgasm, Generation, and the Politics of Reproductive Biology. Representations 14: 1-41. [CrossRef]

Logan, Terence, and Denzell Smith. 1978. The Later Jacobean and Caroline Dramatists. Lincoln: University of Nebraska Press.

Maus, Katharine Eisaman. 1996. Inwardness and Theater in the English Renaissance. Chicago: University and Chicago Press.

Monta, Susannah. 2005. Martyrdom and Literature in Early Modern England. Cambridge: Cambridge University Press.

Moretti, Thomas. 2014. Via Media Theatricality and Religious Fantasy in Thomas Dekker and Philip Massinger's The Virgin Martyr (1622). Renaissance Drama 42: 243-70. [CrossRef]

Munro, Lucy. 2006. Governing the Pen to the Capacity of the Stage: Reading the Red Bull and Clerkenwell. Early Theatre 9: 99-113.

Myhill, Nova. 2004. Making Death a Miracle: Audience and Genres of Martyrdom in Dekker and Massinger's The Virgin Martyr. Early Theatre 7: 9-31. [CrossRef] 
Paster, Gail Kern. 1993. The Body Embarrassed: Drama and the Disciplines of Shame in Early Modern England. Ithaca: Cornell University Press, pp. 23-63.

Paster, Gail Kern. 1998. The Unbearable Coldness of Female Being: Women's Imperfection and the Humoral Economy. English Literary Renaissance 28: 416-40. [CrossRef]

Pickett, Holly Crawford. 2009. Dramatic Nostalgia and Spectacular Conversion in Dekker and Massinger's The Virgin Martyr. SEL: Studies in English Literature: 1500-1900 49: 437-62. [CrossRef]

Ridout, Nicholas. 2006. Stage Frights, Animals, and Other Theatrical Problems. Cambridge: Cambridge University Press.

Scott, Joan Wallach. 1988. Gender and the Politics of History. New York: Columbia University Press.

Winstead, Karen. 2000. Chaste Passions: Medieval English Virgin Martyr Legends. Ithaca: Cornell University Press.

(C) 2019 by the author. Licensee MDPI, Basel, Switzerland. This article is an open access article distributed under the terms and conditions of the Creative Commons Attribution (CC BY) license (http://creativecommons.org/licenses/by/4.0/). 



\title{
"Fantastic Tricks before High Heaven," Measure for Measure and Performing Triads
}

\author{
Emily Bryan
}

Department of Languages and Literatures, Sacred Heart University, 5151 Park Avenue, Fairfield, CT 06825, USA; bryane@sacredheart.edu

Received: 19 January 2020; Accepted: 19 February 2020; Published: 22 February 2020

\begin{abstract}
Reading Measure for Measure through the logic of substitution has been a long-standing critical tradition; the play seems to invite topical, political, and religious parallels at every turn. What if the logic of substitution in the play goes beyond exchange and seeks out a triadic logic instead? This insistent searching for the triad appears most notably in the performance of Measure for Measure by Cheek by Jowl (2013-2019). Cheek By Jowl's strategies of touring, simplicity, movement, and liberation create a dynamic and ever-evolving performance. This article puts Cheek by Jowl's performance of Measure for Measure in conversation with C.S. Peirce's (and subsequent theorists) explorations of triadic logic with Puttenham's rhetoric of traductio (repetition with variation, and "tranlacing"), in addition to critical work on substitutions in the play. Tracing the superfluity of substitutions in rhetoric and performance of the play allows us to see how the play refuses binaries, and energizes triadic logic as a means to liveness in performance. Both Shakespeare's play and the Cheek By Jowl production use a triadic structure which suggests the Trinity, foregrounding the body as a site of mediation and liveness.
\end{abstract}

Keywords: Measure for Measure; Cheek By Jowl; performance; the body; the trinity; Christology; rhetoric; repetition; triadic logic; semiotics

I say móre: the just man justices;

Keeps grace: thát keeps all his goings graces;

Acts in God's eye what in God's eye he is-

Chríst-for Christ plays in ten thousand places,

Lovely in limbs, and lovely in eyes not his

To the Father through the features of men's faces.

Gerard Manley Hopkins, "As Kingfishers Catch Fire."

Life is mysterious and transcends logic, so the living thing can never be fully analysed, taught or learned. But those things that apparently cut out life or seem to conceal or block it, are not nearly so mysterious as they pretend. These 'things' are bound by logic and may be analysed, isolated and destroyed. The doctor may explain why the patient is dead, but never why the patient is alive.

\section{Declan Donnellan, The Actor and the Target}

Placing these two epigraphs together at the start of this article, I hope to put the infused language of poetry in conversation with the lived experience of the theatrical creators, especially in relation to the sign systems that produce meaning in theatrical performance. Following theatre semioticians like Keir Elam, Patrice Pavis, and Fernando De Toro, I recognize in Cheek By Jowl's production a triadic structure which I will argue evokes the Holy Trinity (Elam 1980; Pavis 1992; de Toro 1995). Comparing Hopkins' poem to Donnellan's advice exposes a potential connection among the Trinity, triadic logic in 
performance, and liveness. Hopkins' poem, "As Kingfishers Catch Fire," reveals in its second stanza a theatrical and performative idea of Christ's relationship to humanity. Donnellan's advice to actors unpacks the complicated process of creating or re-creating the live experience. In Hopkins' poem, "the just man" "Acts in God's eye what in God's eye he is-Christ—for Christ plays in ten thousand places" (emphasis mine). The language of performance provides a way for Hopkins to understand the presence of Christ in humanity. When Donnellan advises actors that removing the "blocks" to human experience enhances the actor's performance and allows the mystery of life to be revealed, he describes a process that shows theatrical creation as a dance between the analytical and the mysterious. Hopkins' affinity for the language of poetry as a way to encounter Christology aligns with his desire that his poems be performed; in a letter to his brother he explains that his poetry, "must be spoken, till it is spoken, it is not performed, it does not perform, it is not itself" (Goss 2011, p. 86). Here Hopkins elides the performer with the text itself. If the poem itself is a performative act, then the interpretation of Christ who "plays in a thousand places,/ lovely in limbs, and lovely in eyes not his," must be an act of transference, of movement. The very nature of performance, for Hopkins, requires a Christological worldview where the performance of God is always present, if a moving target. Deeply connected to Hopkins' idea of performance is the rhythm and rhetorical development of his poetry. Having his poems spoken fans them out to breath and to the body. Speaking and enacting his poetry allows the poem to be closer to "itself."

Declan Donnellan's advice to actors also underscores this idea of closeness. In fact, he argues that when actors are "blocked" they experience "paralysis and isolation-an inner locking and an outer locking. And, at worst, an overwhelming awareness of being alone, a creeping sense of being both responsible and powerless, unworthy and angry, too small, too big, too cautious, too ... me" (Donnellan 2013, p. 6). This feeling of being alone, being too much "me," is counter to being alive. As the epigraph above articulates, the doctor can analyze the dead, but cannot account for life. The theatrical experience depends upon liveness, which, for Hopkins, is "charged with the grandeur of God," but for performance theorists might be described another way. Andrew Quick, in "Taking Place: Encountering the Live," advances a description of Live Art that intersects with the tension between the "blocks" Donnellan describes and the electricity of experience in Hopkins' poetry:

The live troubles because it cannot be completely tied down. In order to experience its very liveness we are compelled to be open to the moment-by-moment of the live's happening before applying the rules through which we might presume to understand what is taking place around us. Consequently, 'being live' displaces, if only for an instant, the constellations that bind knowledge and representation together to fashion the narratives and structures that presume to describe and organize phenomena into concrete formations. (Quick 2004, p. 93)

Though "Live Art," which Quick is analyzing, has a particular definition of the combined practices of research and performance by artists, his formulation of the way 'liveness' forces the audience to put on hold the organizing principles that it commonly uses to understand the world corresponds to Hopkins' performative approach to poetry and Donnellan's work as a director of the company, Cheek by Jowl. I am interested in bringing together this verse of Hopkins and Donnellan's approach to theatre because it reveals to me an interest in the liveness of performance that theatre and religion share which is manifest in the triadic logic that many see supporting the system of signs in the theatre, and in the Christian understanding of God as the Holy Trinity. I will argue that theatre and Christianity are inextricably bound up in triadic logic and representations through repetition, substitution, and liberation as demonstrated in both Cheek by Jowl's production and Shakespeare's text, Measure for Measure.

\section{Triads, Liveness, Measure for Measure, and Cheek by Jowl}

My first-hand experience as an audience member of Measure for Measure at the Brooklyn Academy of Music in 2019 transformed my interpretation of the play because it made me ask these questions: 
What happens in performance to the logic of substitution in the play? How does performance interfere with the fulfillment of the sign? Why does Measure for Measure (CBJ, 2019) seem to stage an absent presence that is then over-filled? Why would a production that seems so political and secular feel overdetermined in its representation of the Trinity and Christ? Why does this production feel deeply spiritual in a play that has so long been read as a debate among religious factions or about Kingship in a religio-political moment? ${ }^{1}$ As an audience member, I felt the "liveness" of performance described by Andrew Quick, in that a "constellation of narratives and structures" were constantly circulating, and my expectations as an audience-member kept changing. Donnellan's techniques for producing a live event, one that always feels new for the actors and for the audience, reside in an attentiveness to the immediacy of Shakespeare's language and to the actor's bodies on the stage. Movement and stillness are balanced in equal measure in the production staging, but every moment is engaged and resonant. Both the actors and the text feel fully present and their concentration demands the audience's concentration. ${ }^{2}$ My theatre-going experience, as well as my survey of criticism around the problem of substitution in Measure for Measure, spur me to question how the representation of the Trinity through triadic structures could be shaping the theatrical experience. A description of Donnellan's relationship to religion points to this possibility: "Donnellan is no longer religious in the denominational sense of the word, but there is something of the Polish director Jerzy Grotowski's 'Holy Theatre' cult about him, the idea of theatre being a sacramental art where the collusion of actor and audience will spark an event that, rooted in a celebration of shared humanity, might always carry the potential of divinity" (Coveney 2006). The tension in this description between concepts that feel static ("idea of theatre," "sacramental art") with the terminology of combustion—-collusion," "spark," "potential" — points to the very danger that Donnellan works hard to avoid-a dead, empty or disconnected performance. Shakespeare trades on this tension throughout Measure for Measure, and Cheek by Jowl capitalizes on this tension in performance.

Images of three appear throughout the performance in a provocative and ostentatious way. Three red boxes dominate the stage, variously opaque, transparent, closed and open. (All photographs are by Johann Persson, and can be located at the CBJ site) https://www.cheekbyjowl.com/productions/measurefor-measure/\#imageGallery-216-21. ${ }^{3}$ Before turning to the consideration of how the production coalesces around triads and suggests the Trinity, a consideration of the way in which the system of signs in the theatre hinges on triadic logic is important. As Patrice Pavis describes in "Performing Texts," "Performance is the synchronic confrontation of signifying systems, and it is their interaction, not their history, that is offered to the spectator and that produces meaning" (Pavis 1988, p. 86). The interaction of signifying systems in a theatrical production is difficult to capture and re-envision for a reading. Instantly, those who write about performances run the risk of flattening out the experience and disembodying it. Also, retaining the details of an audience member is subject to the unreliability of memory, and the uniqueness of each performance cannot fully be articulated. In the case of CBJ, the effort to write about and analyze the performances of Measure for Measure is even more wide-ranging, as the production run spanned six years, 24 venues, and over 11 countries. The production is also in Russian with English subtitles, with a very pared-down script. Fortunately, the company created a professional, theatrical film of the production for educational purposes; however, like many recorded theatrical performances the frisson with the audience is absent. Nevertheless, the recording, coupled

1 See, for example, (Beckwith 2011; Besteman 2019; Goossen 2012; Smith 2018; Shuger 2001; Schleiner 1982; Knight 2001; Whalen 2014; Bradizza 2018; Rust 2019).

2 I recognize that the description of the theatrical experience above is subjective; however, whether each individual felt the 'engagement' of the performance, does not undermine that the intent of the design and staging was to engage the audience. This was especially true because the house lights were frequently turned on during the production so that the audience was aware of itself as an audience, and the actors stared directly at the audience, as if they were another character in the performance.

3 (Birksted-Breen) Birksted-Breen notes, as do others, that there are five boxes on the stage, but in the production at the Brooklyn Academy of Music, as well as the theatrical film of the production, only three are really visible. The two side boxes are effectively used as walls. 
with theatrical photography, and many reviews and critical analyses, allows the researcher to present a fuller picture of the stage interactions.

When interpreting the play, Measure for Measure, many critics rely on the moral, religious, or political stances of the characters, but the lived experience of the characters moment-to-moment is elusive. If we consider the way a very fine critic like Anthony Dawson writes about the characters in the play, we can see that there would not be a lot of air in the room for an actor's interpretation. Dawson writes, for example, "Isabella and Angelo are both moral tyrants; both are rigid and cold" (Dawson 1978, p. 110) and later: "The tendency [to abstraction] is reflected in the language of the play, when a recurrent use of the concrete creates a sense of disembodiment, of dissociation of mind and body, feeling and action" (p. 111). In such an appraisal, the characters are flattened out; there is no friction between Isabella and Angelo if they are disembodied. Perhaps part of the problem is what Joshua Daniel describes, in an essay entitled, "The Human Body and the Humility of Christian Ethics," "our bodies are more humble than our narratives" (Daniel 2014, p. 190). The actors' work has to then be incredibly specific and truthful to fill the imaginative space of our stories. Simon Shepherd writes about bodies in the theatre: "theatre is not simply an art of bodies, but an art of bodily possibility" (Shepherd 2006, p. 10). In approaching the work of a theatre company like Cheek by Jowl, it is important to foreground this idea of bodily possibility. However, as Anna Kamaralli brilliantly explains in her essay on performance/criticism of Isabella, there is also a history of bodily and critical violence towards the character of Isabella because she "has the audacity to behave as if she owns her own body" (p. 397). There is a long history of violent stagings of Measure for Measure that Kamaralli interrogates, and which Cheek by Jowl's production participates in, and readers should be aware that some of the links to images included in this text depict violent scenes. ${ }^{4}$ Kamaralli wonders whether these violent scenes really elicit audience empathy or rather feed into a desire for spectacular violence toward women. This observation is an important critique of this production and is also one of the reasons that reviews of the production called attention to the span of time in which it has been performed. The era between 2013 and 2019 witnessed an incredible shift in America, at least, from a nation that was poised to have its first female president to the \#metoo movement. Laura Kolb argues in "The Very Modern Anger of Shakespeare's Women" that Measure for Measure's reception in our culture has shifted in just those few years in the rise of productions, and the changing nature of way she teaches and writes about the play (Kolb 2019). For Cheek by Jowl, the performance of the play over this time could leave traces of these political controversies with its audiences. The lived experiences of $\mathrm{CBJ}$ as a company inform its performances; the voices, gender, race, identity, and languages inform its performances; its mise en scene inform its performances; its varied audiences inform its performances; and the change in historical moments during the company tour inform its performances. Above all the company is actor-focused, while driven by the vision of Declan Donnellan, director, and Nick Ormerod, designer. CBJ tours more than most theatre companies, and they often collaborate with the Pushkin Theatre, Moscow. Declan Donnellan claims that Russian actors who are trained to be more comfortable with movement, provides a different experience than working with their "text-reared British counterparts" (Prescott 2008, p. 192).

The idea that Russian actors have a greater comfort with movement and gesture than actors who focus more on text may be part of the reason that this production drew so heavily on triadic structures that theatre semioticians have long acknowledged as underpinning the theatrical experience. C.S. Peirce's triadic logic has greatly influenced the study of theatrical semiotics. For Peirce, the world is a system of signs in three parts, which he explains as the object, the representamen, and the interpretant, and the sign of the object itself has three modes: the index, the icon, and the symbol. Peirce argues that signs and the creation of meaning are triadic, not binary (Chapman and Routledge 2009, p. 207). Peirce's complex and recursive descriptions of triadic relationships in language and thought are fertile

4 See also (Aebischer 2008). 
concepts to apply to theatrical representation. Ann Berthoff, in a chapter called "Triadic Remedies," explains Peirce's further articulation of triadic logic as "Firstness is Quality, Secondness is Event, and Thirdness is Mediation" (Berthoff 1999, p. 66). Berthoff explains that for Peirce thirdness is "the bridge" to meaning making, the method of interpretation, the idea that other meanings can make meaning (Berthoff 1999, p. 60). Fernando de Toro explains the significance of Peirce's triadic logic, arguing that binary models are an insufficient way to think about the theatre: "in theatre, unlike literary discourse, objects do have a real existence, a real presence, although in the end it only takes the form of the presence of the voice and body of the actor" (de Toro 1995, p. 65). As soon as de Toro articulates the idea of a real presence, however, he replaces it with the "form of the presence," and Umberto Eco also beautifully reveals the ephemeral nature of the sign, describing it in a reading of Peirce as akin to a "dynamic object," and that "Semiosis dies at every moment. But as soon as it dies it arises again like the Phoenix" (Eco 1976, p. 1467). Eco's revelation that the sign and its interpretation are constantly in flux corresponds to the way he interprets Peirce as being "interested in objects, not so much as ontological properties of being, but as occasions and results of active experience" (Eco 1976, p. 1465). The activity and energy present in Peirce's triadic structures is perfectly suited to Cheek by Jowl's performance of Measure for Measure. ${ }^{5}$ The constant shifting of meaning, the use of one sign in relation to another to create meaning, the necessary absent presence of the dynamic object on the stage, and the critical role of the audience as interpretant coalesce in this production.

Reviewers of the production mainly conceived of it as a response to authoritarian rule and oppressive regimes. Russian critics saw the production as "a shattering portrait of contemporary Russia" (Novaya Gazeta). Most UK reviewers mentioned the topical reference to Putin's government, but according to Noah Birksted-Breen, the Russian reviewers did not make direct reference to Putin (Birksted-Breen 2016, p. 88). By the time this production alighted at the Brooklyn Academy of Music in 2018, the \#MeToo movement association was relevant. Laura Collins-Hughes' review in the New York Times recognizes the association: "this production had its premiere in Moscow in 2013, long before the \#MeToo movement emerged as a cultural force. But in a play that examines the vicious abuse of power that people commit when they think nobody's watching, the timeless impossibility of Isabella's position could hardly be more sympathetic, or more central" (Collins-Hughes 2018). The unusually long touring cycle for this production, allows for the permeability of meaning. Like Eco's phoenix of semiotics, the production's resonance with a Russian government "with a regressive law on treason, censorship which bans swearing in the arts, anti-LGBT laws and so on" (Birksted-Breen 2016, p. 90) gained momentum in the wake of its tour during the \#MeToo movement and Brett Kavanaugh's senate confirmation hearing. Keir Elam masterfully describes how this transaction occurs in the theatre, "The performance text, to summarize, is characterized by its semiotic thickness or density, by its heterogeneity and by the spatial and temporal discontinuity of its levels" (Elam 1980, p. 41). Elam describes how spectators come into the theatre in tacit agreement with a number of different codes, theatrical and interpretive, but audience members also bring a system of signs derived from their own experiences and context to apply to the performance (Elam 1980, p. 47).

The political and cultural backdrop of the CBJ production skews in a decidedly secular way, from critiques of oppressive regimes to highlights of a violent patriarchal culture. Donnellan's own statement on the play, while indicating the heterogeneity of meaning that Elam discusses, nevertheless marries personal and political themes: "Measure for Measure is about many different things; it always strikes me as a very modern play. It's a play about control and how one of the ways that we are controlled, by not only governments, but by churches and other institutions that seek to control us, is shame. We are controlled by shame. It starts with parents and it develops, and it is an extremely good way of controlling people" (https://www.cheekbyjowl.com/productions/measure-for-measure/). Donnellan sees a larger emotional mechanism driving the play that is wielded by institutions and

5 See also (Burkhardt 1995) for Peirce's triadic logic in a reading of Measure for Measure. 
interpersonal relations, as well. However, the design of the production, the performances of the actors, the mise en scene (which for Cheek by Jowl usually involves the audience directly), coupled with Shakespeare's text, which revolves around religious questions of sin, forgiveness, and redemption, uses triads in a way that insistently evokes the Trinity.

\section{Triadic Viewing}

In watching the production, I was struck by how often the visual images land on three distinct characters or dimensions of the stage. Using the three red boxes to indicate three different kinds of "cells" the prison, the cloister and the brothel, Nick Ormerod visually supplies the triad that underlies the play. In this first image, the audience can distinctly see the three red boxes that dominate the stage. https://www.cheekbyjowl.com/productions/measure-for-measure/\#imageGallery-216-24.

This second image depicts the three boxes in a more obvious allusion to what they are. Claudio sits in an electric chair, awaiting execution on the left; Isabella stands transfixed in a kind of cloister; and Pompey shags a prostitute in the brothel. That the brothel and the prison bookend the cloister is a powerful commentary on the institutionalized way culture polices and encounters sexuality: https: //www.cheekbyjowl.com/productions/measure-for-measure/\#imageGallery-216-25. The production radiates energy and movement. It begins with the ensemble standing between two of the boxes, a tight group. They all look out at the audience with trained intensity, looking to catch the audience's eye. Their gaze stays trained on the audience for an uncomfortable amount of time. Their facial expressions were unwavering, defiant. By training their gaze on the audience, and using partial house lights on the audience, the actors seem to implicate or invite the audience in whatever journey they are taking. These are not historical bodies, representing a past or some kind of literary tradition; they are in the moment of a lived experience that seems to be happening at that particular moment. As a group, the actors quickly walk around the stage, encircling the boxes; gradually one breaks off, stands too long looking up at a light into the wings of the theater as if staring at the sun, and the others leave him. This is the Duke, not a confident, control-freak, but an introverted, confused man. When we meet Claudio, he is framed by three officers and three boxes loom behind him. The title "Fornicator" hangs on a placard around his neck. https://www.cheekbyjowl.com/productions/measure-for-measure/\#imageGallery-216-3 As the brothel and the prison frame the ends of the stage, we realize that Claudio's crime of sleeping with his fiancée will cost him his life.

In addition to the looming red boxes, both transparent and opaque, Donnellan and Ormerod deploy the actors to create the setting of the performance. In his book-length study of Cheek by Jowl's productions, Peter Kirwan uses this production of Measure for Measure as his final example because it exemplifies Donnellan's philosophy that "everyone is human, and that change—and theatre-come from the understanding that other people are different to me .... . Cheek by Jowl's concept... is to treat characters as humans with stakes, and thus to allow something 'alive' to emerge" (Kirwan 2020, p. 156). Not only does this production attend to the moral and emotional life of the characters, but all of the actors also function as a mob, a crowd, the walls of a prison, etc. As Noah Birksted-Breen observes, "At the centre of this production was the human body as an element of stage design" (Birksted-Breen 2016, p. 88). The actors are onstage almost throughout the entire production, witnessing and judging the actions of the other players. The audience is also implicated in the production, as the characters often gesture to the audience as if it were "the people." The transformability of the actor's body is emphasized in a way that resonates with de Toro's explanation of the theatre sign (which rests on Peirce's triadic logic): “The transformability of the theatre sign is at the very essence of theatricality: in theatre, any sign has the potential of losing its own substance and acquiring another without losing its effectiveness in the process" (p. 71). The very nature of this transformability is at the heart of Peirce's triadic logic. As Umberto Eco and Ann Berthoff both point to in Peirce's work, it is the idea of transmission, process and interpretation that is not static, but evolving that corresponds so well to thinking about the theatrical sign. 


\section{The Logic of Substitution and Figures of Repetition}

It is not surprising, given all the work on semiotics in the theatre using Peirce's triadic logic, that a modern production of Measure for Measure, would resonate with the process of transformability of the sign in the way I have described above. But I think that the play is uniquely responsive to triadic logic and lends itself ultimately to Trinitarian and religious iconography in a deep structural way that Cheek by Jowl, with its emphasis on "liveness" and the transformability of the human experience, could hardly avoid. Before turning to the moments in the CBJ production that most dynamically enact the rejection of the binary, the lure of the triad and the resolution of the Trinity, I argue that the critical reception of the play text corresponds to this move as well. Using a play that has long been featured in critical analyses as an example of substitution (from G. Wilson Knight and William Empson on), I interrogate the varied critical responses to the play's logic of substitution and displacement, and offer as an alternative reading that the rhetorical figures of repetition and substitution in the play point to a triadic rendering of these forms that eschews traditional binary formations the play tries to set up in favor a strident call for more, just as Hopkins begins the last stanza of his Kingfisher poem: "I say more." Encoded in the smallest rhetorical figures in the play is a demand for excess, for replacement that never satisfies.

As Debra Shuger points out in her book on the political theologies of Measure for Measure, it is the only play with an overtly Biblical title, referencing the Sermon on the Mount, Matthew 7:2, "For with what judgment ye judge, ye shall be judged: and with what measure ye mete, it shall be measured to you again" (Tyndale). The repetition in the Bible passage, which Shakespeare simplified, is itself a figure of repetition that George Puttenham identifies in The Art of English Poesy. He calls it traductio or the "tranlacer," writing:

Then haue ye a figure which the Latines call Traductio, and I the tranlacer: which is when ye turne and tranlace a word into many sundry shapes as the Tailor doth his garment, \& after that sort do play with him in your dittie.

The Art of English Poesy: A Critical Edition 2007, p. 304.

The repetition of terms with slight syntactical changes shows the poet, like a tailor, stitching together language to create something new. 6 "Play" with language is a key feature of Puttenham's description of repetition. In the title of his play, Shakespeare takes the Sermon on the Mount and streamlines the repetition to create a balanced syntax. This title represents the beginning of Shakespeare's engagement with repetition in the text. In the title of the play, we can read a simple exchange and repetition, but as the drama unfolds, that repetition is anything but simple. In fact, the play is more likely to "turn" and "tranlace" a word, in spite of the way it asserts the opposite.

As many critics have observed, Measure for Measure begins with an attempted erasure of power. Duke Vincentio decides to step down in favor of his deputy, Angelo. But Vincentio's self-imposed exile hardly mirrors a retirement from public life; instead Vincentio plans to return in disguise to survey his deputy's performance. In turning over the keys to his kingdom, he surmises to Escalus, "What figure of us think you he will bear?" (1.1.16). ${ }^{7}$ Duke Vincentio already imagines Angelo replacing him-"supply (ing)" his "absence." A measure for measure; a Vincentio for an Angelo. By using the language of rhetoric and art, "figure," Vincentio foregrounds the idea of representation, and this is, in many ways, a false representation because Angelo's governance is temporary. The Duke imagines him enforcing the laws that the Duke has failed to uphold, and then the Duke believes that he will eventually reassert his own power. Critics have seen in this the play's debate over contemporary

6 Many critics have written on Shakespeare and the use of repetition, see (Brown 1999; Sears 1973; Hoy and Hibbard 1984; Rauh 2013; Culler 2015).

7 All references to Measure for Measure are from (Shakespeare 2016). 
religious debates between the Puritan and Anglican assertion of civil government and authority. ${ }^{8}$ Also, the binary between private morals and public justice is often asserted in criticism of the play. However, through the figures of repetition in the play, these binaries are constantly challenged, and the language of over-fulfillment is asserted.

Consider that while the characters of government-Angelo, Escalus and the Duke-construct a "balanced" transfer of power, the comic characters-Lucio, Pompey, and Elbow-exert a verbal wordplay of repetition and misdirection that quickly leaves the "balance" of "measure for measure" behind. When we first meet Lucio (described as a "fantastic"), he debates with two gentlemen about the nature of Grace. After tossing the word about as the prayer before the meal, Lucio declares, "Grace is grace, despite all controversy: as, for example thou thyself art a wicked villain, despite of all grace" (1.2.24-26). Like Puttenham's tranlacer, Shakespeare plays with "grace." The controversy is over one kind of grace (by divine appointment), with another (by good works), and yet Lucio inserts a third kind of grace, which the gentlemen is surely lacking. This kind of repetition with a difference is often merged with a third term in Measure for Measure. Shakespeare often sets his clowns to do this work; much like Dogberry, the constable in Much Ado About Nothing, Elbow misplaces his words through repetition and a malefactor becomes a benefactor. Pompey, a bawd and a tapster, uses repetition to assert authority, especially speaking to Escalus and Angelo:

Pompey: And I beseech you look into Master Froth here, sir, a man of fourscore

pound a year, whose father died at Hallowmas. Was't not at Hallowmas,

Master Froth?

Froth: All Hallow Eve.

Pompey: Why, very well: I hope here be truths.

2.1.117-121

After the repetition that confirms his error, Pompey searches for truth, as if the initial incorrect repetition is fully supplied and corrected by the right one. This is a comic turn of the tricolon, where the third term in the repetition bears the humor through deflation, confusion, irony or rejection.

Though Shakespeare's clowns rely heavily on figures of repetition, so too do his more serious characters, Isabella, Angelo, and the Duke. At the beginning of the play, Isabella, a novice of St. Clare's, encounters Angelo and immediately resorts to the kind of repetitive structures we see in the comic character's banter. Pleading for her brother's life to Angelo, who is carrying out a sentence of death on all fornicators (Claudio, Isabella's brother, has impregnated his fiancee, Juliet), Isabella frames her pleas like the tranlacer of Puttenham's Poesy:

There is a vice that most I do abhor,

And most desire should meet the blow of justice,

For which I would not plead, but that I must,

For which I must not plead, but that I am

At war 'twixt will and will not.

\subsubsection{9-33.}

Isabella, like the clowns, plays with repetition and language in a way that makes puns available to Angelo's ears. The doubleness of language kindles in her speech: abhor/abwhore, blow (to strike)/blow (to breathe). Throughout this scene, as Isabella begs for her brother's life and Angelo suddenly finds himself attracted to her, they repeat each other, bouncing back and forth the words, "honor," "fault," "forfeit," "brother," "pity," "sense." Angelo, too, structures his thoughts through repetition, "What's this? What's this? Is this her fault or mine?/The tempter or the tempted, who sins most, ha?/ Not she, nor doth she tempt; but it is I? (2.2.161-164). Not only does he play with these different iterations of

8 See especially: (Diehl 1998; Shuger 2001; Magedanz 2004; Lorenz 2013). 
tempt, but he is picking up Isabella's language from a few lines above, "temporal" and "temptation." Across characters, the poet turns the words, their roots and extensions around in the aural space of the scene.

In a final example, out of the many repetitions and "tranlacings" that happen in the play, when Isabella accuses Angelo in front of the Duke of trying to barter her virginity for her brother's life, she does so with a double repetition that resolves in a third repetition of superfluity:

Angelo: And she will speak most bitterly and strange.

Isabella: Most strange, but yet most truly, will I speak:

That Angelo's forsworn; is it not strange?

That Angelo's a murderer; is 't not strange?

That Angelo is an adulterous thief,

An hypocrite, a virgin-violator;

Is it not strange and strange?

Vincentio: Nay, it is ten times strange.

Isabella: It is not truer he is Angelo

Than this is all as true as it is strange:

Nay, it is ten times true; for truth is truth

To the end of reckoning.

\subsubsection{7-47.}

In the middle of this speech, Isabella accumulates the evidence against Angelo, and in the third repetition, the exhibition of his crime overflows. Shakespeare uses repetition for humor and emphasis, but also to demonstrate excess. Rarely do we find in the text a single repetition, more often there is always a third term, as in this moment that overflows and is overdone (signified even in Mistress Overdone, herself). On the level of the word, Shakespeare heightens the drama and the stakes by investing the language with repetitive structures, and his use of the third level of repetition suggests that the play's initial negotiation of "measure for measure" may not be the whole story.

\section{Measure for Measure and the Attraction to Substitution}

Stitching together variant word forms may be what Shakespeare does all the time as a poet; his ability to play with words is not singular to Measure for Measure by any means; however, he is investing a lot into those repetitive structures in the play on the micro-level, and when we couple that with the logic of substitution that dominates the play and criticism about the play, the draw to substitution seems inevitable. There are really two kinds of substitution happening, one within the context of the play and one without. In the context of the play, the first substitution is Angelo for the Duke, the second is Isabella's chastity for her brother's freedom, the third is Mariana for Isabella in the bed trick that lures Angelo to sleep with his rightful bride and tricks him into thinking he's violated Isabella. ${ }^{9}$ The fourth major substitution within the play is the triple swap of Claudio for Barnardine for Ragozine. Perhaps the most influential essay on the substitution is Alexander Leggatt's 1988 piece in Shakespeare Quarterly, which argued that there is a kind of "gremlin of substitution" that haunts the play. Leggatt articulates more thoroughly than any critic the substitutions happening within the play, spending the most time on the substitution of Mariana for Isabella, as the only successful substitution in the play in the sense that it at least "rights the wrong" committed by Angelo when he broke off his engagement to Mariana. However, Leggatt ultimately concludes that all the substitutions are inadequate, and he resolves that Shakespeare's comic turn in Measure for Measure was to write an imperfect play. He writes that Shakespeare "faced the gap between conception and embodiment, his imagination generated

9 See especially Aebischer and Kamaralli who argue that Angelo is the one character in the play who is "technically raped" (Kamaralli 2016, p. 401). 
image after image of representations that are vivid, but not quite adequate" (Leggatt 1988, p. 359), and earlier in the essay he claims that scholars have a hard time rendering the play as anything more than a morality drama (Leggatt 1988, p. 357). Leggatt's essay is important because it articulates the discomfort with a simple binary substitution.

The play has long invited this kind of analogical thinking, especially in terms of finding God in the play. In 1974, Richard Levin published an essay in PMLA on Measure for Measure entitled, "On Fluellen's Figures, Christ Figures, and James Figures." Aligning the character traits from a character in Henry $V$ with scholarship on Measure for Measure, Levin uses Fluellen's penchant for seeing comparisons and figures in all things to flog fellow critics for looking for Christ Figures in the play. Levin, grumpily, fails to acknowledge in any conventional way the critics who attempt to find Biblical parallels in the play. He simply enumerates, critic \# 1, \# 2 and so on-in doing so, of course Levin de-values the work of many admirable critics: G Wilson Knight, who saw the Duke as a figure of God; Roy Battenhouse, who read the play as a commenting on the Christian idea of atonement and anticipated a criticism of Lousie Schleiner's reading of the play in the context of the parables. ${ }^{10}$ The problem with Levin's biting criticism is that it corrals and dismisses the deeply complicated work of analyzing Shakespeare's plays; of course they are never simply correlative constructions. Shakespeare was generating work to be read and appreciated on the stage by an audience with living, breathing actors whose very embodiment would change the nature of the productions and performances every single time. However, the limitation of Levin's criticism, and the reason even more essays have been generated trying to locate Shakespeare's religious iconography and underpinnings of the play is that Measure as we have seen in the proliferation of repetitive rhetorical structures, and in the multiplicity of substitutions always seems to be generative and repetitive at the same time. Levin's frustration suggests something deeper about the religious iconography in the play, and by refusing to name these critics he accumulates more repetitive structures.

Taking the idea of proliferating or generating substitutions, Huston Diehl suggests that the play's flaws are actually part of a strategy to represent the religious controversies of the time. Diehl finds that the play leans towards the Calvinist sentiments that were defining James' church, arguing with those who find more in common in the play with Catholic notions of atonement and with the somewhat positive representations of monks and nuns. But he pushes his analysis of the play in a direction that I think is very helpful in terms of recognizing the play's investment in substitution and embodiment. For Diehl, the play constructs a thematic understanding of these substitutions that corresponds to Calvinist distrust of idolatry, and the Catholic doctrine of transubstantiation. Diehl reframes Angelo's succumbing to desire for Isabella from a lapse into sin, but rather a confusion of loving virtue and the divine with carnal, idolatrous love. Diehl writes, "The bed-trick does not only trap Angelo in his own perverse lust, hypocrisy, and betrayal; it also reveals his central epistemological error, an error that he is in danger of repeating endlessly: mistaking his limited power for absolute power and confusing his asceticism with perfection, as well as desiring Isabella in place of God" (Diehl 1998, p. 401). Diehl's historicist reading of the play leads him to conclude that the unsatisfactory substitutions are a fault of not knowing. However, this reading portrays Angelo's response to Isabella as a theological problem that seems disembodied, and potentially leaving Isabella unfairly responsible for Angelo's behavior. It also leaves Isabella playing a substitute for God, which Diehl acknowledges she avoids, when she refuses to sacrifice her maidenhead for her brother's life.

Recent readings of the theological/political arguments in the play acknowledge the overflowing nature of the significations in the play. In Matthew Smith's search for a common example of religious experience in the play as a "world-making or socializing institution," he finds that religion in the play is both "within and beyond the law" and that Isabella seeks a "moral identity beyond the law" (Smith 2018, p. 16). Bethany Besteman's analysis of the play also demonstrates the collapse of a binary

10 (Levin 1974; Schleiner 1982; Knight 2001; Battenhouse 1946). 
system, explaining, "Reformed belief in the limitations of the human will point to the collapse of the theory of the King's two bodies," (Besteman 2019, p. 1). Perhaps the most relevant analysis for the way I am thinking about how the Cheek by Jowl performance interacts with the play text of Measure for Measure is an article by Devin Byker on the intercessory language of the play. Like so many critics, Byker's analysis is driven by a dissatisfaction with substitution in the play; "In Measure for Measure, the conceptual tool of substitution alone fails to elucidate the complex extension and retention of self upon which intercessory speech and action hinge" (Byker 2016, p. 406). Byker argues that the play is structured on intercessory speech (one character pleads for another), and Byker's reading of the play ultimately addresses the difference between Catholic and Protestant approaches to intercession and posits Angelo and Isabella on competing sides of substitutionary logic. By claiming a mode of speech for the play that uses triadic logic — the first person pleads on behalf of the second to the third-Byker exposes that substitutions in the play always invite a third term that is not always directly present, but hovers over the exchange. ${ }^{11}$

The other strain of "substitution" criticism on the play looks to correlatives outside the context of the play. When Debra Shuger wrote Political Theologies on Measure for Measure, Linda Tripp was wiretapping Monica Lewinsky, and more recently when Brett Kavanaugh was confronted by Christine Blasey Ford, Twitter recognized the way Angelo and Isabella's story fits squarely in the \#Metoo movement. https://twitter.com/MaeSChaplin/status/1079295162533072896 https://twitter.com/wtsfan/ status/1053964110432333824.

When Angelo presents his diabolical plan to Isabella that he will free her brother in exchange for her chastity, she responds:

Isabella: Little honor to be much believed,

And most pernicious purpose! Seeming, seeming!

I will proclaim thee, Angelo, look for't.

Sign me a present pardon for my brother,

Or with an outstretched throat, I'll tell the world aloud

What man thou art.

Angelo: Who will believe thee Isabel?

My unsoiled name, th'austereness of my life,

My vouch against you, and my place I'the state

Will so your accusation overweigh,

That you shall stifle in your own report

And smell of calumny.

\subsubsection{6-156.}

The series of threats and exchanges:-Isabella's chastity for her brother's life, Claudio's pardon for Isabella's silence-are perverse scales of justice. In tweets about the Brett Kavanaugh hearing, "Who will believe thee, Isabel?" became a kind of rallying cry. The idea that the psychosexual power dynamics of four hundred years ago would be unfurling in the Congress in 2018 drew people to the play. But the play also always invites comparisons; I believe the logic of the substitutions is that the repetitive structures spill over in excess in the play. This kind of energy imbues the play with a power that sustains it beyond its own historical moment and speaks to the kind of combustion discussed earlier.

At the beginning of my discussion of substitutions, I mentioned the first one which really inaugurates the triadic logic in the play: Angelo for the Duke. That first substitution is carefully constructed by Shakespeare not to be an even exchange, but a triumvirate. The Duke's first lines are not to the man replacing him, but to Escalus, explaining that he knows Escalus is so well-versed in government that he can give no advice. The Duke tells Escalus: “Then no more remains/But that

11 Though I am thinking primarily of exchange and substitution in relation to triads and the Trinity, many critics have looked at the play in terms of other exchanges, gendered, legal, and economic. See for example, (Gillen 2017) and (Meyler 2019) 
to your sufficiency, as your worth is able,/And let them work. The nature of our people,/our city's institutions and the terms/For common justice, you're as pregnant in/ As art and practice hath enriched any/That we remember" (1.1.7-13). From the audience's perspective it seems that Escalus is being handed control of the government. The question that follows about Angelo must come as a surprise to Escalus and to Angelo; if Escalus has already been given the commission to govern and is "pregnant" with his knowledge and understanding of Vienna and common justice-what do we need Angelo for? The Duke explains to Escalus: "For you must know, we have with special soul/Elected him our absence to supply,/Lent him our terror, dressed him with our love/And given his deputation all the organs/Of our own power" (1.1.17-21). The slipperiness of the substitutions begins from the first lines of the play. Who is really "replacing" the Duke and why does there seem to be a kind of false equivalency-Escalus is already "sufficient" and Angelo is being "lent" terror and being "dressed in love"? Angelo is supplying an absence, but he seems to be lacking himself. This is clearly a triumvirate of leadership. Angelo is being put to the test more than he is functioning as a substitute. He is not in the place of the Duke; rather, he is being tested to be in the role of the Duke. This three-headed government constructed by the Duke also mirrors the structure of the theatrical performance of the play. At the end of the introduction to the play in the Norton Shakespeare, Brett Gamboa adds a performance note, "Productions of Measure for Measure can convince audiences that any of the play's three leads-the Duke of Vienna, Isabella, or Angelo-occupies its central position and each role can be played so as to deserve sympathy or condemnation, so performances can feel revelatory even to those who know the play" (Shakespeare 2016, p. 276). In a performance that pull of the triad is felt, with different balances depending on the performance. In an essay on Twelfth Night, Paul Dean argues that Shakespeare uses triads to reveal the Trinity, responding to both Plato and Augustine. Dean demonstrates that many critics have looked to his poetry to convey a triadic and ultimately Trinitarian reading of love (Dean 2001, pp. 501-2). The love triangles in Twelfth Night always resolve two into one, as do triadic renderings in the poetry.

At the end of Isabella's first scene of pleading her case to Angelo to save her brother, she explicitly invokes the Trinity:

Alas, alas,

Why all the souls that were were forfeit once,

And he that might the vantage best have took

Found out the remedy. How would you be

If he, which is the top of judgment should

But judge you as you are? Oh, think on that

And then mercy then will breath within your lips,

Like man-new made.

2.2.75.

The language here of "forfeit" or debt of remedy or healing, of judgment, of mercy, of breath and of a man "new made" opens up the play to seeing the Trinity. The judgement of the Father-which Angelo is called upon to rise to, but at which he will fail; the sacrificial nature of atonement by Christ, the Spirit breathing life into the newly created man. Isabella is asking him to imagine himself relationally like the Trinity. This moment corresponds to the way Augustine describes the Trinity as a relationship, not a substance. Augustine writes that God, the Father, Son and Holy Spirit are known and understood in relation to each other (Augustine and McKenna 2002, p. 236). In Book 9 of his treatise on the Trinity, Augustine teases out the metaphor of three gold rings, made of the same substance, but individual in characteristics, writing, "It is just as if you were to make three similar rings from one and the same gold, yet they are related to one another in that they are similar, for everything similar is similar to something" (Augustine and McKenna 2002, p. 277, emphasis mine). Here Augustine anticipates C.S. Peirce's description of a triadic sign system where the sign requires interpretation and that we can only understand the system by means of mediating structures of signification. Angelo explicitly rejects Isabella's claim to the Trinity, asking him to imagine himself in a triadic relationship where he might 
be able to look inward to interrogate his cruelty towards Claudio. He says, "Be you content, Fair maid. It is the law, not I" (2.2.79-80) and there, Angelo sidesteps the role she wants him to adopt. It is the law, not I. Isabella always complicates the substitutions that Angelo would like to make when she almost anticipates his bargain: "We cannot weigh our brother with ourself" (2.2.126). ${ }^{12}$ Isabella rejects any false equivalence to judge others, whereas Angelo seems comfortable in that role.

While Isabella rejects this philosophical exchange early on in the play, she accepts the morally questionable bed trick later, allowing Mariana to stand in for her with Angelo, and this is ultimately an unsatisfying exchange because Angelo does not stop her brother's execution but only hastens it. In Philip Lorenz's reading of the play, the issue of the bed-trick is put in the context of the trope of bodily exchange. Lorenz's interpretation of the play links these bodily exchanges to the ideas of transplantation and transfer. He writes that the play works as "a representational paradigm of theologico-political sovereignty in which the 'absence' created by the departed sign creates an institutional desire that can only be satisfied by the substitution of another sign" (p. 65). Lorenz argues that the play depends on the movement of metaphor from "the proper to something else" (p. 74). His articulation of the way substitutions work in the play as creating an institutional desire corresponds to the way I see the logic of the Trinity working on the play, and which Cheek by Jowl's production incorporates.

\section{The Lure of Three}

In Cheek by Jowl's production, the character of Barnardine, played by Igor Teplov surfaces in an extra-textual way as he haunts the Duke (Alexander Arsentyev) dressed as a convict. In this image from the performance, he hangs on the Duke in a parasitical clasp. https://www.cheekbyjowl. com/productions/measure-for-measure/\#imageGallery-216-16. Donnellan's use of Barnardine in this production responds to Shakespeare's creation of important triads in the play, the three heads, three deaths, and three executions. When the exchange of Mariana's body (as Isabella) fails to elicit the release of Claudio, the Duke has to supply another head to satisfy Angelo's order. The sacrifice of these three "convicts" (Claudio, Barnardine, and Ragozine) recalls the three crucifixions on Mount Golgotha, with Christ flanked by two thieves. To complicate this simple substitution of one convict's head for another, Shakespeare presents us with the comic moment of Barnardine-a convicted murderer too drunk to agree to die. Barnardine has been languishing in the prison for nine years, spending most of it in a stupor, with very little interest in ever leaving the confines of the prison. The Provost describes Barnardine in a comic way reminiscent of Puttenham's tranlacer, "A man that apprehends death no more dreadfully but as a drunken sleep: careless, reckless, and fearless of what's past, present, or to come; insensible of mortality and desperately mortal" (4.2.140-144). When the Duke tells Barnardine that he will hear his last confession, Barnardine cannot stomach it: "I have been drinking all night-I am not fitted for it" (4.3.42-43). Surprisingly, the Duke agrees: "A creature unprepared, unmeet for death;/And to transport him in the mind he is were damnable" (pp. 66-68). To save Claudio, the Provost of the prison comes up with a third head-one Ragozine who happened to have died that morning of a fever. They agree that Ragozine even bears a closer resemblance to Claudio. The storyline of Barnardine is completely superfluous as it turns out, and critics are divided as to why Shakespeare included it, many arriving at the comedy of the moment as its true instigator. Stephen Greenblatt, in Shakespeare's Freedom, sees Barnardine as an emblem of autonomy-his willful refusal to be directed into death symbolizes, for Greenblatt, Shakespeare's desire for artistic freedom (Greenblatt 2012, pp. 7-16). However, I see more echoes in the story of Barrabas and narratives of releasing a prisoner or even more importantly in the drive of the play to have three substitutions. Like the triumvirate of the Duke, Escalus and Angelo at the beginning of the play, Shakespeare gives us the three convicts-Claudio, Ragozine and Barnardine. In his essay on substitutions, Leggatt points out that "God acts on humanity

12 Byker describes Angelo's position as an “anti-representational stance” (Byker 2016, p. 419). 
through a series of substitutions: the Incarnation, the Eucharist, and the Priesthood" (p. 340), but Leggatt ultimately does not see the Trinity as a driving force in the play.

Beyond the visual representation of threes in the CBJ production, the textual creation of triads in the play, and the substitutions that always seem unsatisfying, there is finally an inescapable draw in the production to triads that the audience can see in the movement of the characters. The resolution of three in the performance often reveals itself in the way the company constitutes presence on the stage. Cormac Power's book on presence in the theatre provides a useful way to think about how Cheek by Jowl's approach to the playtext invites triadic logic and the Trinity. Power explains that "Theatre affirms its presence by making its 'presence' enigmatic" (Power 2008, p. 14). In the performance of Measure for Measure by CBJ, there are several moments when presence is made enigmatic in a way that signals the compensatory logic of the triad. First, in Isabella's first scene with Angelo, the Provost hovers on the edges of the scene, ostensibly involved in paperwork. When Angelo tells her "Your brother dies tomorrow. Be content," Isabella falls to her knees, facing the audience, saying the "Our Father." Angelo, discomfited, but attracted to her faith and/or her innocence or an inexplicable pull, drops to his knees next to her. The Provost slightly shifts standing above them; Angelo looks to him, and in a comic moment, the Provost slowly descends to his knees until the three of them stare out silently praying in front of the audience. This pull of the Provost to join the prayer seems inescapable, and is also a turning point for Angelo, as his attention to Isabella shifts at that point. He had barely noticed her, prior to this moment. There is an enigmatic presence that pulls the actors into three. When Isabella returns to plead for her brother's life, the production enacts another moment of an absent presence that demonstrates again how the logic of the triad-not just substitution—fuels the sense of liveness and tension in the play. Prior to Isabella's entrance to their next scene together, Angelo prowls agitatedly around the stage. Isabella, ignorant of his change in tone and energy, kisses his hand to beg for her brother's life, and it is as if she ignites a powder keg. He pushes her back to the table and gropes her. In this image you can see her anguish as he asserts power over her both physically violent, and chillingly abusive. https://www.cheekbyjowl.com/productions/measure-for-measure/\#imageGallery-216-11. Just after this moment, he takes off her shoes and sucks on her toes. Part of her body stands in for the whole, as he possesses and caresses her foot while gazing under her skirt. He grabs her to force himself on her, but she bites him, stopping the attack. He leaves her with the unholy bargain that she rejects. When she leaves, Angelo sniffs and caresses her chair in a haunting, possessive way that signals the surging desire for the absent presence that courses through the play. The chair becomes a representation of Isabella, and the kind of shifting signifying from actor's bodies, to set pieces and back again is energized. Later, when Isabella tells Claudio of the bargain, and he tentatively suggests that she might agree to it, Donnellan and the company choose to stage an attempted assault on Isabella by her own brother, recalling, as Birksted-Breen notes, an enactment of Isabella's suggestion that this is a kind of incest on his part. These two images show the way the production stages substitutions in a triadic way. In the first image, the company holds Claudio (Petr Rykov) aloft over Isabella. https://www. cheekbyjowl.com/productions/measure-for-measure/\#imageGallery-216-23. And when this assault is disrupted by the company, Claudio turns violently to play the bass fiddle, replacing the body with the instrument, https://www.cheekbyjowl.com/productions/measure-for-measure/\#imageGallery-216-18. These moments trade on the triadic logic of the theatre's signifying system that reveal the danger in the instability of the substitutions. The chair and the bass fiddle as the erotic substitutions for Isabella in the production demonstrate the objectification and dehumanization of Isabella. The constant use of substitutions and exchanges, coupled with the repeated gesturing to the audience inviting them into the performance, as mob, as the people, as witnesses, and as judges gives the production its dynamism and its terror.

Finally, I come to the most striking moment of all which draws us into the Christology of the play in a decidedly secular production. Barnardine, the prisoner who is too drunk to die, who is, as I have mentioned, the doppelganger of this Duke, stalks the Duke, and he dances a dance of death with him. The bare-chested, thin, dirt-covered Barnardine is almost a stand-in for 
the Duke, physically. They are similar in height and stature, but Barnardine is the completely unaccommodated man. Shorn of his hair and most of his clothing, he is the most basic of human beings. When the Duke pardons him, after a tense waltz/drunken dance, Barnardine collapses onto the lap of the Duke. For a moment, the two freeze under a spotlight and they become a framed, theatrical pieta. Barnardine is draped across the Duke, cradled by the him like Christ, in Mary's arms. https://www.cheekbyjowl.com/productions/measure-for-measure/\#imageGallery-216-38.

In the fifth act of the production, the Duke strolls forward with Angelo and Escalus on the red carpet; they cross the single red carpet and join at the singular microphone, but the image of the three politicians is backlit so that three shadows loom forward. https:/www.cheekbyjowl.com/productions/ measure-for-measure/\#imageGallery-216-36.

This image brings together what the play sets out in the beginning, the triad of male leaders. I want to suggest that even in a production that seeks the explicitly political themes in the play, the Christian imagery, and especially the iconography of the Trinity finds a way in because it really is underpinning the logic of the play through the signifying system of triadic logic. Theresa Coletti, in her book, Mary Magdalene and the Drama of Saints: Theater, Gender, and Religion in Late Medieval England writes that Christian Drama in the West begins with the recognition of a lost body.... accounts of the Marys who seek, but do not find, the body of Christ at the tomb" (Coletti et al. 2004, p. 190). That Barnardine becomes an image of Christ in this production is disconcerting, but also on some level absolutely right. If the play hinges on the logic that repetition (and therefore, performance) cannot be about a dead imitation, but a lively variation, then taking Barnardine, synonymous with one of the thieves on Golgotha, and transforming him into a Christ figure upends and fulfills the triad. In an essay on mercy and the creative process in the play, Dayton Haskin articulates the ethical implications of the way the play invites the Trinity in: "To imagine the needy brother as an Alter Christus presupposes a basic respect for and gratitude to Christ himself" (Haskin 1977, p. 358). Though not a theatre company invested in Christian iconography, Cheek by Jowl, in its articulation of empathy, the ability to imagine another person's perspective, allows Barnardine to "act in God's eye what in God's eye he is-Christ," as Hopkins wrote.

Funding: This research received no external funding.

Conflicts of Interest: The author declares no conflict of interest.

\section{References}

Aebischer, Pascale. 2008. Silence, Rape and Politics in 'Measure for Measure': Close Readings in Theatre History. Shakespeare Bulletin 26: 1-23. [CrossRef]

Augustine, Saint, and Stephen McKenna. 2002. The Trinity. Washington: Catholic University of America Press, Available online: https://sacredheart.idm.oclc.org/login?url=https://search.ebscohost.com/login.aspx?direct= true $\& \mathrm{db}=$ nlebk\&AN=498885\&site=ehost-live\&scope=site (accessed on 12 December 2019).

Battenhouse, Roy W. 1946. Measure for Measure and Christian Doctrine of the Atonement. PMLA 61: 1029-59. [CrossRef]

Beckwith, Sarah. 2011. Shakespeare and the Grammar of Forgiveness. Ithaca: Cornell University Press, Available online: https://sacredheart.idm.oclc.org/login?url=https://search.ebscohost.com/login.aspx?direct=true\& $\mathrm{db}=$ nlebk\&AN=673706\&site=eds-live\&scope=site (accessed on 24 December 2019).

Berthoff, Ann E. 1999. The Mysterious Barricades: Language and Its Limits. Toronto: University of Toronto Press, Scholarly Publishing Division, Available online: https://sacredheart.idm.oclc.org/login?url=https: //search.ebscohost.com/login.aspx?direct=true\&db=nlebk\&AN=468594\&site=eds-live\&scope=site (accessed on 1 November 2019).

Besteman, Bethany C. 2019. Bondage of the Will: The Limitations of Political Theology in Measure for Measure. Religions 10: 28. [CrossRef]

Birksted-Breen, Noah. 2016. Review of Shakespeare's Measure for Measure (Directed by Declan Donnellan for Cheek by Jowl and the Pushkin Theatre) at the Silk Street Theatre, Barbican Centre, London, 16 April 2015. Shakespeare 12: 88-91. [CrossRef] 
Bradizza, Luigi. 2018. Christian Ethics and Political Moderation in Shakespeare's Measure for Measure. In The Soul of Statesmanship: Shakespeare on Nature, Virtue, and Political Wisdom. Edited by Khalil M. Habib and L. Joseph Hebert. Lexington: Lexington Books, Available online: https://search.ebscohost.com/login.aspx? direct $=$ true \&scope $=$ site $\& d b=$ nlebk\&db=nlabk\&AN=1880314 (accessed on 16 February 2020).

Brown, Penelope. 1999. Repetition. Journal of Linguistic Anthropology 9: 223-26. [CrossRef]

Burkhardt, Louis. 1995. Spectator Seduction: Measure for Measure. Texas Studies in Literature and Language 37: 236-63.

Byker, Devin. 2016. Bent Speech and Borrowed Selves: Substitutionary Logic and Intercessory Acts in Measure for Measure. Journal of Medieval and Early Modern Studies 46: 405-32. [CrossRef]

Chapman, Siobhan, and Christopher Routledge. 2009. Key Ideas in Linguistics and the Philosophy of Language. Edinburgh: Edinburgh University Press, Available online: https://sacredheart.idm.oclc.org/login?url=https: //search.ebscohost.com/login.aspx?direct=true\&db=nlebk\&AN=268090\&site=eds-live\&scope=site (accessed on 27 December 2019).

Coletti, Theresa, Bodies Theater, and Sacred Mediations. 2004. Mary Magdalene and the Drama of Saints. Pennsylvania: University of Pennsylvania Press, pp. 190-217. Available online: http://www.jstor.org.sacredheart.idm.oclc. org/stable/j.ctt5hjkht.10 (accessed on 14 September 2019).

Collins-Hughes, Laura. 2018. Sex, Lies and Vindication in a Most Timely 'Measure for Measure. Available online: https://nyti.ms/2QWy7ro (accessed on 15 September 2019).

Coveney, Michael. 2006. “As He Likes It: Profile of Declan Donnellan." The Guardian. Available online: https://www.theguardian.com/stage/2006/feb/04/theatre (accessed on 2 February 2020).

Culler, Jonathan D. 2015. Theory of the Lyric. Cambridge: Harvard University Press.

Daniel, Joshua. 2014. The Human Body and the Humility of Christian Ethics: An Encounter with Avant-Garde Theatre. Journal of the Society of Christian Ethics 34: 189-210. [CrossRef]

Dawson, Anthony B. 1978. Measure for Measure. In Indirections. Toronto: University of Toronto Press, pp. 109-28. Available online: http://www.jstor.org.sacredheart.idm.oclc.org/stable/10.3138/j.ctt1h1hpm2.10 (accessed on 15 September 2019).

de Toro, Fernando. 1995. Theatre Semiotics. Toronto: University of Toronto Press, Available online: www.jstor.org/ stable/10.3138/9781442682597.10 (accessed on 26 December 2019).

Dean, Paul. 2001. 'Comfortable Doctrine': 'Twelfth Night' and the Trinity. The Review of English Studies 52: 500-15. [CrossRef]

Diehl, Huston. 1998. 'Infinite Space': Representation and Reformation in Measure for Measure. Shakespeare Quarterly 49: 393-410. [CrossRef]

Donnellan, Declan. 2013. The Actor and the Target. Available online: https://search.ebscohost.com/login.aspx? direct $=$ true $\&$ scope $=$ site $\& d b=$ nlebk $\& d b=$ nlabk $\& A N=689978$ (accessed on 29 September 2019).

Eco, Umberto. 1976. Peirce's Notion of Interpretant. MLN 91: 1457-72. [CrossRef]

Elam, Keir. 1980. The Semiotics of Theatre and Drama. Methuen: Second Floor-Books, Available online: https://sacredheart.idm.oclc.org/login?url=https://search.ebscohost.com/login.aspx?direct=true\& $\mathrm{db}=$ cat07708a\&AN=slc.45720\&site=eds-live\&scope=site (accessed on 16 September 2019).

Gillen, Katherine. 2017. Chastity and the ethics of commercial theatre in measure for measure, pericles and the revenger's tragedy. In Chaste Value. Edinburgh: Edinburgh University Press, pp. 33-86. Available online: www.jstor.org/stable/10.3366/j.ctt1pwt37f.6 (accessed on 4 February 2020).

Goossen, Jonathan. 2012. Tis Set down so in Heaven, but Not in Earth': Reconsidering Political Theology in Shakespeare's 'Measure for Measure'. Christianity and Literature 61: 217-39. [CrossRef]

Goss, Erin M. 2011. 'Almost Unmade': Hopkins and the Body Apocalyptic. Victorian Poetry 49: 83-103. [CrossRef] Greenblatt, Stephen. 2012. Shakespeare's Freedom. Chicago: University of Chicago Press.

Haskin, Dayton. 1977. Mercy and the Creative Process in Measure for Measure. Texas Studies in Literature and Language 19: 348-62.

Hoy, Cyrus, and G. R. Hibbard. 1984. The Language of Fletcherian Tragicomedy. In Mirror up to Shakespeare. Edited by J. C. Gray. Toronto: University of Toronto Press, pp. 99-113. Available online: http://www.jstor.org. sacredheart.idm.oclc.org/stable/10.3138/j.ctt1vgw98p.11 (accessed on 4 February 2020). 
Kamaralli, Anna. 2016. Putting on the Destined Livery: Isabella, Cressida, and Our Virgin/Whore Obsession. In A Feminist Companion to Shakespeare. Edited by Dympna Callaghan. Hoboken: Wiley Blackwell, Available online: http://public.ebookcentral.proquest.com/choice/publicfullrecord.aspx?p=4453722 (accessed on 16 February 2020).

Kirwan, Peter. 2020. Shakespeare in the Theatre: Cheek by Jowl. London: Bloomsbury Arden.

Knight, George Wilson. 2001. The Wheel of Fire: Interpretations of Shakespearian Tragedy. Abingdon-on-Thames: Routledge.

Kolb, Laura. 2019. The Very Modern Anger of Shakespeare's Women. Electric Literature. Available online: https://electricliterature.com/the-very-modern-anger-of-shakespeares-women/ (accessed on 16 February 2020).

Leggatt, Alexander. 1988. Substitution in 'Measure for Measure'. Shakespeare Quarterly 39: 342-59. [CrossRef]

Levin, Richard. 1974. On Fluellen's Figures, Christ Figures, and James Figures. PMLA 89: 302-11. [CrossRef]

Lorenz, Philip. 2013. Reanimation: The Tears of Sovereignty: Perspectives of Power in Renaissance Drama. Bronx: Fordham University, pp. 59-96. Available online: http://www.jstor.org.sacredheart.idm.oclc.org/stable/j. ctt13x0cvt.6 (accessed on 14 September 2019).

Magedanz, Stacy. 2004. Public Justice and Private Mercy in 'Measure for Measure'. Studies in English Literature, 1500-900 44: 317-32. [CrossRef]

Meyler, Bernadette. 2019. Dramatic Judgments: Theaters of Pardoning. Ithaca: Cornell University Press, pp. 33-74. [CrossRef]

Pavis, Patrice. 1988. From Text to Performance. In Performing Texts. Edited by Michael Issacharoff and Robin F. Jones. Pennsylvania: University of Pennsylvania Press, pp. 86-100. Available online: www.jstor.org/stable/ j.ctv5136rw.10 (accessed on 29 December 2019).

Pavis, Patrice. 1992. Theatre at the Crossroads of Culture. Abingdon-on-Thames: Routledge, Available online: https://sacredheart.idm.oclc.org/login?url=https://search.ebscohost.com/login.aspx?direct=true\& $\mathrm{db}=$ nlebk\&AN=97890\&site=eds-live\&scope=site (accessed on 29 December 2019).

Power, Cormac. 2008. Presence in Play: A Critique of Theories of Presence in the Theatre. Leiden: Brill|Rodopi, Available online: https://sacredheart.idm.oclc.org/login?url=https://search.ebscohost.com/login.aspx?direct= true \&db=nlebk\&AN=222718\&site=eds-live\&scope=site (accessed on 29 December 2019).

Prescott, Paul. 2008. Declan Donnellan. In The Routledge Companion to Directors' Shakespeare. Edited by John Russell Brown. Abingdon-on-Thames: Routledge.

Quick, Andrew. 2004. Taking Place. In Live: Art and Performance. Edited by Adrian Heathfield. Abingdon-on-Thames: Routledge.

Rauh, Sister Miriam Joseph. 2013. Shakespeare's Use of the Arts of Language. Abingdon-on-Thames: Routledge.

Rust, Jennifer R. 2019. Religious and Political Impasses in Measure for Measure. In The Cambridge Companion to Shakespeare and Religion. Edited by Hannibal Hamlin. Cambridge: Cambridge University Press.

Schleiner, Louise. 1982. Providential Improvisation in Measure for Measure. PMLA 97: 227-36. [CrossRef]

Sears, Donald A. 1973. The Translacer: A Rhetorical Thread of a Shakespearean Sonnet. CEA Critic 35: 11-15.

Shakespeare, William. 2016. The Norton Shakespeare, 3rd ed. Edited by Stephen Greenblatt, Walter Cohen, Suzanne Gossett, Jean E. Howard, Katherine Eisaman Maus and Gordon McMullan. New York: W.W. Norton \& Company.

Shepherd, Simon. 2006. Theatre, Body and Pleasure. Abingdon-on-Thames: Routledge, Available online: https://sacredheart.idm.oclc.org/login?url=https://search.ebscohost.com/login.aspx?direct=true\& $\mathrm{db}=$ nlebk\&AN=650847\&site=ehost-live\&scope=site (accessed on 30 December 2019).

Shuger, Debora K. 2001. Political Theologies in Shakespeare's England: The Sacred and the State in Measure for Measure. London: Palgrave.

Smith, Matthew J. 2018. "At War 'Twixt Will and Will Not": On Shakespeare's Idea of Religious Experience in Measure for Measure. Religions 9: 419. [CrossRef]

Whalen, Benedict J. 2014. Private Conscience, Public Reform, and Disguised Rule in The Malcontent and Measure for Measure. Ben Jonson Journal 21: 73-91. [CrossRef]

(C) 2020 by the author. Licensee MDPI, Basel, Switzerland. This article is an open access article distributed under the terms and conditions of the Creative Commons Attribution (CC BY) license (http://creativecommons.org/licenses/by/4.0/). 

Article

\title{
"Beautiful and New": The Logic of Complementarity in Hedwig and the Angry Inch
}

\author{
Adam Beyt \\ Department of Theology, Fordham University, New York, NY 10458, USA; abeyt@fordham.edu
}

Received: 16 September 2019; Accepted: 5 November 2019; Published: 8 November 2019

\begin{abstract}
This article suggests that reading John Cameron Mitchell's musical Hedwig and the Angry Inch as a religious classic undermines the logic of complementarity within Catholic theological anthropology, particularly the Theology of the Body of John Paul II. A religious classic, a term coined by theologian David Tracy, describes a work with an "excess of meaning" that offers hope and resistance against a normative social structure. Hedwig resists the hegemonic structure of sexual dimorphism, as represented by the logic of complementarity operative within the Theology of the Body. This theological anthropology proposes a normative framework for human beings as gendered and sexual agents who "complete" each other through heterosexual and monogamous marital acts, reinforcing heterosexist and transphobic bodily norms. The work of Judith Butler helps illuminate the embodied performance of gender that the musical so brilliantly subverts. Hedwig, while toying with gender norms, also undermines the idea of the logic of complementarity-namely, that each person has another "half" that will cause completion, bringing human flourishing. In the title character not finding a version of "completeness" by the end of the show, the musical, thus, offers hope for those who cannot fit into gendered bodily norms.
\end{abstract}

Keywords: musical; gender; queer; Butler; Tracy; embodiment; theology; anthropology; John Paul II

\section{Introduction}

With musical hits like The Color Purple, Fun Home, Head Over Heels, Pricilla, Queen of the Desert, Rocky Horror Show, Kinky Boots, Falsettos, and La Cage aux Folles, Broadway musical theater as a genre of artistic expression never feared contending with the complexities of LGBTQ+ issues. While several gay and lesbian characters are proudly represented, there are very few lead roles that tell the life and times of trans* individuals. ${ }^{1}$ One notable exception is the 1998 Off-Broadway musical, Hedwig and the Angry Inch. Written and originally performed by John Cameron Mitchell, the show tells the story of Hedwig, a German-born rock singer who strives to find love and acceptance both as an artist and singer. The "Angry Inch" part of the title comes from Hedwig's botched sex change surgery that results in her body as being sexed as neither male nor female but caught in a liminal space. ${ }^{2}$ With this graphic and

1 The asterisk is added to trans in order to illustrate how the term can encapsulate the new ways of being in the world. As described by Jack Halberstam, the marker points to "a politics based on a general instability of identity and oriented toward social transformation, not political accommodation." He continues, "the category takes the prefix for transitivity and couples it with the asterisk that indicates a wildcard in internet searches; it is a diacritical mark that poses a question to its prefix and stands in for what exceeds the politics of naming and recognition." This gestures toward the failure of current and future classificatory systems that humans can come up. For him, the idea is "not to impose ever more precise calibrations of bodily identity but rather to think in new and different ways about what it means to claim a body." In other words, the purpose of the category of trans*, in it being fragmented, segmented, and multiple, is to point to it being "a capacious and fluid category rather than a diagnosis" (Halberstam 2018, p. 88).

2 While Hedwig's character may be described as intersex or gender queer, the character is generally referred to using feminine pronouns. Since the character does not describe herself as transgender and the show refers to the surgical procedure as a "sex change," I opt to describe the incident thusly rather than as a gender confirmation surgery. 
unusual premise for a show, the character is rife for using the tropes of musical theater and glam-rock for meditating on non-normative experiences of gender and embodiment.

One of the main themes of the show concerns "the logic of complementarity." This logic describes how every person has a supposed "partner" that functions to "complete" that person. By this logic, a person remains incomplete and unfulfilled until finding one's "better half." In operating under this logic, finding a significant other is one of the most important goals for achieving happiness and flourishing. While the logic of complementarity disseminated into popular culture-think of the ubiquity of the term "soul mate"-such logic is also present within religion as well. As represented by the interpretation of Genesis of Pope John Paul II in the collection of texts called "Theology of the Body," the logic of complementarity is crucial for setting the grounds for a normative anthropology, here referring to an understanding of what it means to be human in relation to God.

The musical Hedwig and the Angry Inch, while not explicitly grappling with Theology of the Body, contends explicitly with the logic of complementarity. As articulated by the myth of Aristophanes from Plato's Symposium, Hedwig aspires to find her "other half" in a world that perpetual rejects her as a legitimate artist and viable romantic partner. The show engages specifically with the logic of complementarity within Christianity through the character Tommy Gnosis through a lens not unlike the interpretation of Genesis proposed by John Paul II. Indeed, the show might be read as a "religious classic," one that offers hope and resistance over against pervading gender norms. I argue for an interpretation of the show as its own theological anthropology that posits hope for those who do not or cannot long for a significant other that "completes" them in these mythologized accounts of being human.

While Mitchell makes no direct reference to Roman Catholic Theology of the Body in the text of the musical itself, he was, however, raised as a Roman Catholic during the pontificate of John Paul II. He eventually came to reject his Catholicism by becoming both a Radical Faerie and a Universal Life Minister (Universal Life Church 2019). As this reading later shows, both the character and the author reject normative understandings of the human person based on the logic of complementarity and offer a radically new anthropology.

Firstly, this article explains what is meant by a religious classic, here referring to a text, event, person, or work of art that gives excess to meaning as an act of resistance against normative structures. In this case, the normative structure refers to the "logic of complementarity," as exemplified by the Theology of John Paul II. Then, the work of Judith Butler is marshaled to help illuminate the complex dynamics of gender and embodiment operative within the show. Finally, the text of the show is analyzed at length in order to propose an alternative theological anthropology to the logic of complementarity.

\section{Hedwig and the Angry Inch-A Religious Classic?}

As a contemporary theologian deeply engaged with philosophical hermeneutics, David Tracy is famous for his theories of religious interpretation, especially with his term, "religious classic." A classic has "an excess of meaning" that "demands constant interpretation and bears a certain kind of timelessness" (Tracy 1981, p. 102). This is an instance whereby the interpreter is called to be "vexed, provoked, challenged by the claim to attention of the text itself" (Tracy 1981, p. 105). A classic transforms "if only for a moment, ourselves: our lives, our sense for possibilities and actuality, our destiny" (Tracy 1981, p. 110). The classic is created when an artist dives into reality to tell us something new and true about existence. The artist or author enters a moment of intensification that takes one into new territories. This diving into new existence allows us as interpreters of it to see something new, "its fatedness, its challenge, its finitude, its horrors, its possibility, its joy." Through this process, people who encounter the work are led to believe that such intensification is worth its risk. It allows those who encounter the work to realize that we now grasp essential truths that were not realized outside of this diving into reality (Tracy 1981, p. 126). 
The religious classic is characterized by this "diving into reality" in relation to human encounters with God. For Tracy asserts, the task of the theologian is to interpret encounters with God as religious classics as acts of hope and resistance. In interpreting religious classics, we allow them "to challenge what we presently consider possible. To interpret them is also to allow ourselves to challenge them through every hermeneutic of critique, retrieval, and suspicion we possess." His work with a variety of thinkers led him to explore the possibility of interpreting God in fairly unconventional sites. Within the constellation of thinkers labeled as "post-modern" Tracy notes how "the language of love as in the love of the mystics, along with their use of erotic and sometimes violent, transgressive language" was used for constructive and political ends alike (Tracy 1994, pp. 314-15). Another aspect of this constellation of dispositions is a prophetic impulse seeking to overthrow the oppression and hegemony of modernity. For Tracy, an experience of God is manifested within the groups designated as "non-persons," folks thrust to the margins of society. The voice of God is mediated through "hysterics, fools, avant-garde artists, and dissenters of all kinds" (Tracy 1994, pp. 317-18). Discerning different ways of talking about God means interpreting new and unusual sources that have the potential to give way to an "excess of meaning." For Tracy, religious beliefs become acts of hope that are also "acts of resistance against the status quo" (Tracy 1987, pp. 84-85). They are an awareness of God as the Ultimate Reality and an innate concern for those often made the societal Other (Tracy 1987, p. 104). The person who interprets a religious classic will discern "the interruptive presence of Ultimate Reality empowering a way of life otherwise thought impossible" (Tracy 1987, p. 108). Tracy's notion of the religious classic emphasizes new ways of understanding God as concerned for marginalized communities, thus offering hope and resistance to help imagine new ways of being in the world.

One aspect of Tracy's articulation of the term "religious classic" is the ambiguity for its qualifications. As a Roman Catholic theologian, he posits the Christ event, the life and death of Jesus of Nazareth, as the "religious classic" par excellence. This leads him to claim that all theology is a "hermeneutical endeavor" since all Christian thought traces its origins to an interpretation of the Christ event (Tracy 1981, p. 64). His references to works of art that do contain an "excess of meaning" seem to be what one would expect for a gender-conforming, white priest who spent decades in academia: the Sistine Chapel, the music of Bach, and the poetry of T. S. Eliot. ${ }^{3}$ The choice of these works into this "religious classic" canon suggests more about the tastes and background of Tracy than the works themselves. As with every consumer of art and media, his choice of works to examine is limited by his particular horizon of experience. This same limitation, of course, leaves space for other interpreters inhabiting alternative horizons to examine different texts in a similar manner.

Hedwig and the Angry Inch is a fairly recent addition to the American musical theater canon, making its Off-Broadway debut in 1998. Within that short timeframe, Hedwig became immensely popular within the past 20 years, with multiple productions throughout the world, a 2001 film with a cult following, national tours, and a hit Broadway revival in 2014. ${ }^{4}$ For such a show to achieve rabid popularity, surely there must be some kind of "excess of meaning" to which people are extrapolating from the show? Furthermore, given the many philosophical and religious themes running throughout the text of the show, the show, if anything else, seems rife for theological engagement. Hedwig certainly qualifies as a religious classic insofar as it gives way to an excess of meaning, operates from a marginalized perspective, and tries to rail against a normative structure, in this case, sexual and gender dimorphism and the relational norms that help maintain its power.

3 See his commentary on the recent "Heavenly Bodies: Fashion and the Catholic Imagination" exhibit at the Metropolitan Museum of Art in New York City for an example of his analysis of Roman Catholic art (Tracy 2018).

4 Indeed, with the 2014 revival of Hedwig and the Angry Inch, the once subterranean and subversive show seems to have reached "mainstream" audiences. The show opened on 24 April 2014, with openly gay (and immensely popular) actor, Neil Patrick Harris, in the title role. The production ran for 507 regular performances, receiving multiple Tony wins in June of 2014 , including best actor for Harris and best revival of a musical. The role of Hedwig was filled by many mainstream and celebrity actors, including Andrew Rannells, Michael C. Hall, John Cameron Mitchell, Darren Criss, and Taye Diggs. The Broadway revival ran for a total of 507 performances after 22 previews (Broadway.com 2015). 


\section{Theology of the Body and the Logic of Complementarity}

If Hedwig is to be read as a religious classical, i.e., an interpreted work of art that acts as a tool of resistance, what exactly is the musical resisting? To bring the musical into the realm of the theology, one first needs to be familiar with theological anthropology and how it relates to the logic of complementarity as exemplified in the Theology of the Body of Pope John Paul II.

The work of John Paul II functions as what Christian theologians refer to as theological anthropology. Theological anthropology describes the critical reflection on the human person in relation to God. If systematic theology describes how things hang together in relation to God, theological anthropology is the subfield in which human beings, namely, human embodied experiences, get taken into consideration. Theological anthropology is crucial for the field of sexual ethics because ethical claims on what a human person "does" as a sexual agent are typically based on what a human person "is." This subfield within theology is also a fraught topic, due to its collusion with pernicious ideologies. Positing one normative definition of the "human" often leads to a totalitarianism that marginalizes bodies that do not conform to that particular norm. ${ }^{5}$ Theological anthropology often proves to be the source of violence from within Christianity, be it in a linguistic, metaphysical, or corporeal manifestation.

Within contemporary Roman Catholic theological sexual ethics, the pervading model for theological anthropology, Theology of the Body, creates a totalizing norm for the human person as a gendered and sexual agent, and this anthropology operates through the logic of complementarity. The logic of complementarity presupposes two potential embodied frameworks for human beings: biological males and biological females who must "complete" each other in a monogamous, marital union. Within this model, the body in which a person is born dictates how they are to inhabit the world. For the latter half of the 20th century, the greatest champion of the logic of complementarity was Pope John Paul II. This body of work, combined in a collection of papal addresses and documents often referred to a Theology of the Body, articulates the logic of complementarity through an interpretation of the creation story of Genesis. In basing his anthropology on a myth, explicitly interpreting the myth as articulating a fundamental anthropological reality, John Paul II normalizes a fixed view of gender based on sexual dimorphism.

Here, the word "myth" is not being used as in pejorative or dismissive manner. A myth, as described by Terrence Tilley, is a "story that sets up a world." He adds that myths are powerful within religious texts insofar as to accept a myth is to "accept it as expressing a fundamental truth about the world." Tilley helpfully notes that the creation myths of Genesis in particular may be read as "a human representation of the created world as fundamentally good" (Tilley 2010, pp. 76-78). Both Hedwig and John Paul II provide interpretations of myths as articulating fundamental truths about the human person.

For the sake of this article, one need only examine a brief excerpt of his writings to understand how this logic of complementarity permeates his work. In the set of lectures titled "Original Unity of Man and Woman," the pope turns to the beginning of Genesis in order to ground his anthropology. The lectures are framed as an interpretation of the indissolubility of marriage expressed by Jesus in Matthew 19. In order to further explain the theological significance of this gospel passage, John Paul II returns to the same passage from Genesis referenced within the words ascribed to Jesus. For him, Jesus is operating from a normative understanding of sexual ethics based on a distinct anthropology. He focuses on the second account of creation, writing how it "forms a conceptual and stylistic unity with the description of original innocence, man's happiness, and also his [sic] first fall" (John Paul II 1997, p. 27). According to the first account, the human person, in being created male and female, is to procreate. The second account, however, contains "the most ancient description and record of man's

5 Theological anthropology allowed theological discourse to become the culprit of many pernicious social evils. Examples of the problems it causes abound. For examples on the topic of race, see Copeland (2010) and Jennings (2010). For an example of gender, see Gonzalez (2007). 
self-knowledge" (John Paul II 1997, pp. 28-29). Within the narrative of the second account of creation, as the reader may know, the first woman was created from the rib of the first human. Subsequently, the human person was, at one point, divided and seeks to be united through the marital act and the procreation of children.

Within this account, John Paul II observes that the human person exists in solitude, yet longs for the company of others (John Paul II 1997, p. 35). For him, "Man is a subject not only because of his self-awareness and self-determination, but also on the basis of his own body. The structure of this body permits him to be the author of a truly human activity. In this activity the body expresses the person" (John Paul II 1997, pp. 40-41). This takes the form of "the signs of sex" and "is male or female by its nature." This leads into a version of "masculinity" and "femininity" that each person needs in order to be "complete." Notably, John Paul II refers to this narrative as a "myth" insofar as it is "an archaic way of expressing a deeper content" (John Paul II 1997, p. 43). Based on this, he writes, "the woman is for the man, and vice versa, the man is for the woman" (John Paul II 1997, p. 45).

Within this anthropology, human bodies can fall into one of two normative categories as sexed bodies that are assigned at birth. Each person is inherently viewed as "incomplete" from having been torn asunder from one's supposed "other half." Each person also remains "incomplete" until finding one's "other" half. From this anthropology, one gleams the two norms of traditional Roman Catholic sexual ethics: unity and procreation. Since human beings are taken apart from each other, their "completion" through heterosexual and monogamous marriage allows this unity to take place. In addition to being "unifying," sex must be procreative in being open to life. As a result of this understanding of the human person, any deviation from these two norms is in some way problematic. Topics like same-gender sex, polyamory, sexual promiscuity, contraception, and pre-marital sex are all regarded as sinful. As succinctly observed by Charles Curran, "The Theology of the Body as developed by John Paul II, however, cannot serve as a theology for all bodies" (Curran 2005, p. 168). Regarding gender, the logic of complementarity reifies gender norms into metaphysical concepts, marking versions of trans ${ }^{*}$ embodiment as deviants. ${ }^{6}$ Individuals who are intersex are not even legible as theological considerations of embodiment.

The logic of complementarity is then proven to cause multiple theological consequences due to one normative framework for embodiment. For queer Roman Catholics today, such a formulation of the human body leads to marginalization and feelings of worthlessness. Salzman and Lawler achieved both acclaim and criticism for attempting to reformulate Theology of Body as a "relational complementarity." While not unlike what is seen with Hedwig's employment of the myth of Aristophanes in Plato's Symposium, the authors expand the framework offered by John Paul II to include same-gender couples. Problems still emerge when one's form of embodiment does not fit into a normative gender role. The authors posit "a holistic complementarity, which includes sexual orientation complementarity as one of its types, embraces the totality and complexity of the human person, and reconstructs genital complementarity to be in dialogue with, and at the service of, personal and orientation complementarity." For them, "the genitals may be said to be complementary when they are used in a moral sexual act that realizes the psychoaffective, social, and spiritual elements of ontological complementarity" (Salzman and Lawler 2008, p. 91). While this model is more inclusive, the framework still presupposes an inherent "lack" that can be completed within a relationship. A person, as a relational entity, still demands to be complimented somehow.

\section{Hedwig and Gender}

Since the logic of complementarity relies so much on philosophical and theological formulations of gender, some of the work of Judith Butler provides a helpful tool to understand how the title character

6 The recent document administered by the Congregation for Catholic education only further doubles down on this version of gender essentialism. See (Congregation for Catholic Education 2019). 
subverts such binaries. In a performed musical that ruminates so extensively on notions of gender and identity, Hedwig and the Angry Inch seems perfect for exploring some of Butler's ideas on the performative facets of gender. Firstly, an introduction to some of Butler's thought is due. Butler is most famous for popularizing the notion of the performativity of gender in her seminal work, Gender Trouble: Feminism and the Subversion of Identity. While the text initially sought to critique heterosexist versions of so-called "French Theory," which itself was responding to the overly patriarchal readings of Freud offered by Jacques Lacan, the notion of "gender as a performance" is what became most famous. ${ }^{7}$ What is meant by this concept? Referring to gender as a performance indicates how it functions as a normative, yet socially constructed, script regarding the manner in which sexed bodies are expected to inhabit the world.

Gender, for Butler, refers to a "norm" that demarcates some human bodies as different from other human bodies. Norms illustrate how human bodies are always caught up in language in materializing within human forms of signification. ${ }^{8}$ Norms operate as bodily social conventions and actions that dictate hegemonic ways of being human. As described by Leticia Sabsay, Butler's formulation of norms "structure and inform bodily practices that enact psychic processes of identification by which we come into being. They are pre-predicative, not explicit, and learned in embodied practical ways" (Sabsay 2016, p. 292). A norm as a regulatory tool "is always and only tenuously embodied by any particular social actor." Gender, as a norm, refers to that which "governs the social intelligibility of action," especially in relation to sexed bodies. Norms are conventions that determine which bodily practices are recognizable, "imposing a grid of intelligibility on the social and defining the parameters of what will and will not appear within the domain of the social" (Butler 2004, pp. 41-42). Norms not only describe one's conduct but also condition the possibility of recognition (Butler 2005, p. 25). They, thus, describe the conditions of the emergence of the self as a social entity (Butler 2005, p. 8).

One of Butler's most famous phenomena used to illustrate the "performative" aspect of gender is one immediately relevant to an analysis of Hedwig: drag. For her, drag illustrates a particular role in relation to the subversion of gender. Drag is that which "troubles" how one thinks of gender because it can "elucidate a structure that is at work in everyday performances of gender, and so to make this reiterative production of reality-effects legible as a repeated practice in so-called ordinary social life." As this becomes clear in Hedwig, drag illustrates the idea that "'reality' is given to certain kinds of gender appearances over others, and that those who are transgendered are regularly debased and pathologized for 'not being real.'" Drag can undermine the apparent "essentialism" present within assumptions about gender. "The point," she writes, "is that the ontological field is mobilized by power relations, and that what we come to regard and affirm as 'real' or 'unreal' can and does undergo critical change depending on social mobilizations of various kinds" (Butler 2006, p. 282). Within the context of the musical, Hedwig attempts to "perform" her role a woman. She aspires to "assume" a body, to use Gayle Salamon's phrase, regarding her gender identity (Salamon 2010). Yet the status of her genitals being described as the "one-inch mound of flesh" prevents her from achieving being regarded as a "real" woman. She, thus, remains, as shown, a queer outlier, one stuck in the performative contradiction of being neither a "man" nor a "woman" yet inhabiting an unusual liminal space.

In an article on the movie adaptation of the show, Matthew Henry employs some of the work of Butler, and his analysis of the film is relevant to some of the major themes of the show. With the "socially constructed" aspects of gender having influenced an entire generation of filmmakers, the film "offers a loud and radical challenge to received ideas about queer identity; in short, the film works to subvert binary categories, to contest hegemonic ideologies, and to destabilize essentialist notions of sex, gender, and sexuality." The film, while on the surface, appears to be tragic, but it is

7 See Butler's response to the critiques of Gender Trouble in the 1999 Preface to the text (Butler 1990, pp. vi-xxviii). See also "Can the 'Other' of Philosophy Speak?" for an autobiographical account of her engagement with the reception of text (Butler 2004).

8 This is the meaning of the title to Butler's 1993 follow-up to Gender Trouble, Bodies that Matter. 
liberating and empowering in illustrating "the constructed nature of gender" through parody (Henry 2016, pp. 65-67). Notably, Hedwig, is not a transgender character, at least in the most commonly depicted narrative tropes associated with gender dysphoria. Starting at a small queer-friendly venue called the Squeezebox in New York City, Hedwig's character came into existence as a live singer, one person with a clearly performative identity that would be torn off at the end of each performance. So, for Hedwig's conception, there is no narrative of "longing to become her true self" or "being born into the wrong body." Hedwig's transition is done out of practical necessity for her to travel to the United States, yet it is an identity she embraces as she pursues her stage persona.

Henry observes the ways Mitchell uses "philosophical concepts" to get points across to the viewer. Mitchell intended the myth of Aristophanes to be essential for interpreting the character as a "walking metaphor" for the myth (Henry 2016, p. 69). Henry highlights how "completeness" as part of one's romantic quest disseminated Western culture. This version of anthropology operates under the logic of complementarity and often re-inscribes versions of gender roles, even within lesbian and gay communities, often in terms of "butch/masculine" and "feminine" pairings of couples. This obviously fails to accommodate trans* individuals who do not fall so easily within such demarcations. Henry observes that Mitchell "is intent on critiquing the romantic myth of love," as articulated in the logic of complementarity, "and exposing it as a fallacy" (Henry 2016, p. 70). In an interview, Mitchell notes that the romanticizing of relationships based on the logic of complementarity has a negative effect. He observes, "it brings up all these ideas about monogamy, sexuality, and gender, and the myth is great, because it includes every possible kind of attachment. But you never will, no matter how hard you hold onto someone, become one person." Henry observes how the film version seeks to undermine the famous line stating from Jerry Maguire: "You complete me." For Henry, "The mythological search for another is rendered false, and the film becomes a tale of self-acceptance, self-identification, and self-actualization" (Henry 2016, p. 73). Henry also observes how as a media item, the film is intent on "interrogating, if not dismantling, the 'sacred order' of normative sex and gender categories, thereby challenging conventional notions of sexuality, desire, and love." He adds that it can be "read in political terms as a liberatory text because it offers viewers a vision of unrestrained freedom: the knowledge of one's self combined with the ability to freely choose and to (re)create one's identity" (Henry 2016, p. 75). Henry, thus, validates the film version as a liberatory text to resist hegemonic formulations of gender in addition to undermining the logic of complementarity.

While Henry's work is helpful for analyzing the film version of the show, he ignores the explicit religious themes running throughout. Furthermore, the embodied aspect of the thematic material takes on new meaning in a live performance. Rather than grappling with an image on a screen, the audience experiences a living, breathing body in front of them. Given that gender remains a distinctly embodied phenomenon, seeing a living body on stage playing with gender norms can often yield a stronger affective response. Seeing a person on stage will easily, for many, create a greater degree of empathy and attention from viewers if the performer is dancing and singing right before them. More significantly, formulations of theological anthropology are meant to relate to living human bodies in order to make a substantive claim on people's lives. Theological formulations of the human, thus, take on greater weight if a living person present—even as a performance-can help to undermine them.

\section{5. "You Complete Me"}

Having described the logic of complementarity within religious language, formulations of the performativity of gender in the thought of Butler, and how her ideas relate to the film version, an analysis of the musical itself is now in order. ${ }^{9}$ As described by Henry, Hedwig and the Angry Inch

9 The version analyzed here is based on the 1998 Off-Broadway production. The script for the 2014 Broadway version is slightly different. Specifically, the premise for the production is altered in order for the character to have a reason to be performing in that venue. For this production, Hedwig takes over a theater in which a production of the fictional Broadway musical adaptation of the war film The Hurt Locker just closed. This set-up is meant to mock the pervasive occurrence 
troubles the romantic aphorism, "you complete me." Indeed, the narrative of the musical is based on Hedwig's attempt to fulfill an anthropology based on the logic of complementarity, and, by the end of the show, she disavows this belief in finding peace in her own uniqueness. Her frustrated attempts to find "completion" through a romantic partner invites the viewer to consider the futility of the logic of complementarity and the norms that demarcate gender.

The show begins with an articulation of Hedwig's status as a queer outlier. From the outset, her body's existence is meant to destabilize gender binaries. Born as a boy in East Germany, Hedwig is seen as crossing over the wall of a country in the same way she attempts to cross over the "wall" of a perceived gender binary. The opening track, "Tear Me Down," summarizes the transgressive aims of the character: "I was born on the other side/ of a town ripped in two/ I made it over the great divide/ Now I'm coming for you" (Mitchell 1998, p. 14). Her identity is presented in relation to its liminal subversion of normative binaries. Yitzhak, her current Jewish husband and fellow bandmate, shouts out,

The world was divided by a cold war

and the Berlin wall

was the most hated symbol of that divide...

Ladies and Gentleman

Hedwig is like that wall

standing before you in the divide

between East and West

Slavery and Freedom,

Man and Woman

Top and Bottom (Mitchell 1998, p. 15)

Hedwig's existence troubles hotly kept binaries, and this status made her hated. She finishes the song with, "There ain't much of a difference/ between a bridge and a wall./ Without me in the middle, babe/ you would be nothing at all" (Mitchell 1998, pp. 15-16). In a unique aspect of self-awareness, Hedwig understands how the liminal status within a binary illustrates the limitations of that binary.

She then sets up the story to be about her relationship with her rock protégé, Tommy Gnosis, but to do that, Hedwig turns to describing her background and how ideas of "completion" motivated her from her youth. She mentions her mother and tells an anecdote about watching Jesus Christ Superstar with her. Hedwig, as a young boy, says "Jesus said the darndest things," which leads to a slap in the face as a rebuke. The young Hedwig and her mother fall asleep. They lie in bed, and Hedwig describes them as "like two pieces of a puzzle that don't quite fit but are jammed together and left on a table by ... (railing at the heavens) ... some dangerous shut-in with too much time on his hands," as if illustrating how loneliness defined her life even from an early age (Mitchell 1998, pp. 22-23). She then sings "The Origin of Love" as a "bedtime story" her mom would tell her.

The "Origin of Love" is a retelling of the myth of the creation of humanity by Aristophanes from Plato's Symposium. Mitchell felt this myth was so significant that he opted to publish a version of the myth at the end of the publication of the script for the musical. In the song, humanity originally consisted of three differently sexed bodily types: males with males (the children of the son), females with females (children of the moon), and males with females (children of the moon). The gods realize

within Broadway to adapt movies into musicals due to their being a recognizable commodity and, thus, less of a financial risk. Later in the show, Yitzhak sings "When Love Explodes," a song from the aforementioned fake musical. These slight modifications to the show are more for comedic effect and illustrate the show's acceptance into a more mainstream musical theater canon insofar as there needs to be an explicit justification within the world of the show for Hedwig's presence in a Broadway theater. 
that humanity grows too powerful and seek to make humanity weaker by separating them from each other. "Love" is brought to existence as the longing of a separated person for the respective "other half." Human beings "make love" when they smash their bodies against each other in an attempt to find meaningful wholeness (Mitchell 1998, pp. 25-31).

While the narrative of the myth of the song differs from the Platonic text in that it includes non-Greek deities, with references to Osiris, Thor, and "some Indian god," the logic of complementarity remains the same. Upon completing the song, the young Hedwig is deeply impacted by the song and wonders about finding the missing half:

"It is clear that I must find my other half. But is it a he or a she? Is it Daddy? He went away. Or Mother? ... What does this person look like? Identical to me? Or somehow complementary? Does my other half have what I don't? Did he get the looks, the luck, the love? Were we really separated forcibly, or did he just run off with the good stuff? Or did I? Will this person embarrass? And what about sex? Is that how we put ourselves back together again? Is that what Daddy was trying to do? Or can two people actually become one again? And if we're driving on the Autobahn when it happens, can we still use the diamond lane?". (Mitchell 1998, pp. 31-32)

Hedwig adds that she is asking, "practical questions of wholeness. Completion." She thought of the "power" that the gods themselves feared when he achieves completion with his missing half (Mitchell 1998, p. 32).

One first notes a number of parallels between the myth of Aristophanes the musical invokes and the use of the Genesis creation myth from Theology of the Body. Both posit a normative view of the human based around the logic of complementarity. Admittedly, the myth offered by Plato seems to be more inclusive insofar as it provides space for same-gender couples. In this sense, one could view this myth as an enrichment of the creation myth suggested in Genesis. Yet problems still emerge. Specifically, the myth still reifies the existence of only two embodied gender configurations. For folks such as Hedwig, a character who has neither an identifiable penis nor vagina, her body cannot fit into this paradigm. Furthermore, the myth still imposes a version of "fulfillment" that will emerge in finding one's "other half." This idea of "wholeness" and "completion" offered by the myth of Aristophanes-one that only leads to heartbreak and sadness-provokes much of the action of the character in the musical.

Continuing with the recollection of her youth, Hedwig mentions how she meets Luther, an American soldier living in East Germany. Luther quickly develops a romantic relationship with her and offers her candy in the process of his courtship. In the song, "Sugar Daddy,"10 Hedwig relishes in the power she has over Luther in the relationship, "Oh the thrill of control/ like the rush of rock and roll/ is the sweetest taste I've known." Luther, in a brief line of dialogue in the show, suggests Hedwig would look better in a dress, "And I was thinking you'd look so fine/ in a velvet dress/ with heels and an ermine stole." Hedwig agrees, "So you think only a woman/ can truly love a man./ Then you buy me a dress/ I'll be more woman/ than a man you can stand." She invokes classic artistic representations of femininity, "I'll be your Venus on a chocolate clam shell/ rising on a sea of marshmallow foam" (Mitchell 1998, pp. 39-41).

Hedwig agrees to marry Luther, and, in order to do so, she also agrees to have a vaginoplasty operation. The operation, of which Hedwig sings in "The Angry Inch," is a failure. Rather than having a vagina or a penis, she has something peculiar caught between:

When I woke up from the operation

10 The song arrangement for the original Off-Broadway version and the 2014 Broadway revival is notably different. In the Off-Broadway version, as in the movie, the number comes across more as a country song. In the Broadway revival, which was performed at the 2014 Tony Awards, the song is much more upbeat and fast-paced. The number was effectively turned into a more conventional "show-stopper" to make the production more similar to mainstream Broadway shows. 
I was bleeding down there

I was bleeding from the gash between my legs

my first day as a woman

and already it's that time of the month

But two days later

the hole closed up.

The wound healed

and I was left with a one-inch mound of flesh

where my penis used to be

where my vagina never was (Mitchell 1998, p. 45)

According to the norm of one's genitals determining one's gender, Hedwig is neither a man nor a woman but caught in some liminal space. At this point, from a technical standpoint, Hedwig might be considered intersex but is never referred to as such. Like the wall that she sings about in the opening song, Hedwig is an outlier that somehow stands in the middle of a strict binary. Within the logic of sexual complementarity of Theology of the Body, along with the myth of Aristophanes, this character can no longer find another "half" who will complete her due to a failure to meet bodily norms.

Upon arriving to the United States (US), the Berlin Wall falls as Luther leaves Hedwig for another man. Having moved to Junction City, Kansas, Hedwig decides to create a new rock persona for herself and embark on a musical career as "punk rock star on stage and screen." She then performs "Wig in a Box," and, in the number, Hedwig puts on various wigs and adopts different personas, such as a "Miss Midwest Midnight Checkout Queen" or "Miss Beehive 1963."

At one point during the song, she sings, "I look back on where I'm from/ look at the woman I've become/ and the strangest things/ seem suddenly routine" (Mitchell 1998, p. 47). Here, many readers of Butler's work are tempted to apply a common misinterpretation of her work to the scene. Many interpret this philosopher, especially after only reading Gender Trouble, that gender is performative in the sense of donning a wig and a dress one day. In the beginning of Bodies that Matter, Butler criticizes this misreading of her work. She writes, "For if I were to argue that genders are performative, that could mean that I thought that one woke in the morning, perused the closet or some more open space for the gender of choice, donned that gender for the day, and then restored the garment to its place at night." Such a willful autonomy, an image of an individual who is somehow able to float above political and societal norms, is inconsistent with her thought as a whole. Gender, like other norms, "is constructed through relations of power and, specifically, normative constraints that not only produce but also regulate bodily beings" (Butler 1993, p. ix). For Butler, bodies, mediated through norms, go through a process of materialization "that stabilizes over time to produce the effect of boundary, fixity, and surface we call matter" (Butler 1993, p. xviii). A Butlerian reading of this number does suggest, however, that Hedwig invokes the prescriptive norms associated with gender in donning the various wigs. Rather, it is the inevitable failure of Hedwig to fulfill the norms of being a "woman" that point to the non-essential characteristics of gender.

After finding her persona as a "punk rock star of stage and screen," she then tells the story of her meeting Tommy Gnosis. The boy, then going by Tommy Speck, is described as a "Jesus freak with a fish on his truck." She finds him to be "incredibly hot. Perhaps it was his disdain for authority, his struggle with organized religion" (Mitchell 1998, p. 57). Throughout the musical, Tommy represents a person who also believes in a version of the logic of complementarity, albeit in an explicitly Christian form. Like with the writings of John Paul II, Tommy cites his version of this story as part of an interpretation of the creation myth of Adam and Eve within Genesis. After performing the song, "Little Wicked Town," a lament about the struggles of being a misfit in a small town, Hedwig takes the young Tommy under her wing. 
When they meet, Tommy asks her, "Have you accepted Jesus Christ, the Son of God, as your personal savior?" Hedwig replies, "I told him I was aware of Our Lord. Loved his work." Tommy then notes how Jesus "saved us from His fucking father." He expresses disdain at God's punishing Adam and Even when "Eve just wanted to know shit" (Mitchell 1998, p. 61). After her student completes the rock curriculum, Hedwig gives him the last name "Gnosis," the Greek word for knowledge, to reference Eve's desire for knowledge. ${ }^{11}$ Within Tommy's stage name, there lies a reference to the biblical myth of the origin of humanity.

After a few months of performing and success, Tommy and Hedwig find themselves collaborating more and more. One day, Hedwig is helping Tommy and looks into his eyes, noticing "new lenses, one blue and one pink," suggesting the two colors often ascribed to the normative gender binary. They then have a conversation about "immortal love," gesturing toward the "metaphysical" articulation of gendered complementarity operative in both John Paul II and Plato. Hedwig notes, "Well, perhaps because love creates something that was not there before." Tommy asks, "What, like procreation?" Hedwig adds, "Sometimes just creation" (Mitchell 1998, p. 64). Here, Tommy specifically mentions the "procreative" aspects of gender complementarity present with Christian thought. Tommy seems to adhere to this logic and mentions the part that creates new life as that which makes complementary love sacred in the first place.

She then paints a sliver cross on his forehead. Tommy then sings, "Look what you done. You made me whole. Before I met you, I was the song. But now I'm the video." Hedwig is then filled "with an ancient clarity" before realizing, "He's the one." In the staging of the show, the "Origin of Love" faces appear, both male and female, suggesting Hedwig's journey to find her "other half" is over. She says,

No blood in my eyes, no blood on his face. He's the one. The one who was taken. The one who left. The twin born by fission. He'll die in fusion, our fusion, cold fusion, unlimited power, unlimited knowledge, the secrets he must hold, the memories that we shared but are now forgotten, the words to complete the sentence that I began. (Mitchell 1998, p. 66)

Again referencing the creation myths, Tommy then adds that Eve was separated from Adam and "Paradise was lost. So, when she enters him again, Paradise will be regained!" (Mitchell 1998, p. 66) As he touches the mass of flesh between her legs, Tommy and Hedwig kiss. He then leaves her, disgusted and knowing that he will not be able to find mythological completion.

Hedwig then sings "The Long Grift" as a lament for his departure. Helplessly, Hedwig turns to Yitzhak, saying how they're both survivors, "The German and the Jew. Think of the symmetry. Think of the power. Think of the publicity. The gods would be terrified" (Mitchell 1998, p. 68). Yitzhak then spits in her face. In "Hedwig's Lament," she sings how she disseminated her heart to other people, "I gave a piece to my mother/ I gave a piece to my man/ I gave a piece to the rock star/ he took the stuff and ran." The next song, "Exquisite Corpse," describes violently how these experiences tore her up, "A collage/ all sewn up/ a montage/ all sewn up" (Mitchell 1998, p. 71). Hedwig then tears off her bra, revealing two tomatoes in place of her breasts. Smashing the tomatoes against her body, she destroys her fabricated stage persona and gender identity. The person playing Hedwig then comes back as the Tommy Gnosis character. In the reprise of the "Wicked Little Town," the song begins with “Forgive me,/ for I did not know./ 'Cause I was just a boy/ and you were so much more/ than any god

11 Readers familiar with early Christianity might be tempted to label this as a reference to Gnosticism, an early sect contemporaneous with the rise of Christianity that came to be regarded as heretical by the proto-orthodox church. This constellation of religious beliefs was notable for its emphasis on divine knowledge and repudiation of the good of material realities (Brakke 2010). Some, such as Henry, suggested that Tommy's stage name references the "self-knowledge" Hedwig emphasizes (Henry 2016, pp. 71-72). A thorough account of Gnosticism exceeds the scope of this article. There is no substantive evidence beyond the use of the same Greek word to suggest that Mitchell is referencing this particular set of beliefs through Tommy's character. Since his stage name emerges immediately after a discussion of the Fall due to Eve's desire to "know shit," this suggests a reference to the Tree of Knowledge rather than a lesser known religious and philosophical cult contemporaneous with the formation of Christianity. 
could ever plan,/ more than a woman or a man." The lyric continues "That, when everything starts breaking down,/ you take the pieces off the ground/ and show this wicked town/ something beautiful and new." Showing the true growth past the logic of "wholeness," the character sings, "You think that Luck/ has left you there./ but maybe there's nothing/ up in the sky but air./ And there's no mystical design,/ no cosmic lover preassigned./ There's nothing you can find that cannot be found." Singing one last time of Hedwig's status as an outlier, "'Cause, with all the changes/ you've been through,/ it seems the stranger's always you,/ alone in some new wicked little town" (Mitchell 1998, pp. 73-74).

For the final song, "Midnight Radio," Hedwig returns to the stage when the two faces from the "Origin of Love" return projected on stage. In the song, Hedwig expresses fondness for the misfits of the world. She sings, "Know in your soul/ like your blood knows the way/ from your heart to your brain/ know that you're whole" (Mitchell 1998, p. 75). She belts, "Lift up your hands," as if in an act of praise to God. On the stage, the projected male and female faces merge into one, suggesting Hedwig found an alternative and queer way beyond this myth of "completion" (Mitchell 1998, p. 79).

\section{Conclusions}

What can one gather from this ambiguous ending? Hedwig does not find her "other half." There is no romantic ending-just satisfaction in the character's own "incompleteness." For those who never seem to be "whole," for those who do not seem to fit into conventional norms of gender, to be the person a transwoman or some other gender configuration, there is hope. This work operates as a "religious classic" in Tracy's terms because it offers an understanding of theological anthropology that resists normative versions of what it means to be human. Rather than concern about fulfilling any norm whatsoever, Hedwig walks off into the future not knowing who or "what" she definitely is and remains content with that. The musical, thus, proposes a theological anthropology that celebrates being a "misfit," embracing one's status as a societal "Other" as a source of creative potential over and against social marginalization. The "failure" of Hedwig in her quest for "completion" suggests the foolishness of such a quest itself. Rather than posit "procreation" that takes place through finding one's "other half," her character arch suggests a new "creation" that can be brought about by simply existing as her authentic self. Notably, this version of "authenticity" resists the more normative form outlined by Taylor (1991). Rather, this version of authenticity is about survival in a world that intends to reject someone who cannot fit into normative categories. Hedwig and the Angry Inch is not about a journey of a trans* person becoming more accepting by others. The show is explicitly about the title character's search for love despite having a queer form of embodiment. Indeed, the title evokes Hedwig's relationship with what makes her so unique: her particular body—her "angry inch" of flesh that does not fit into any preconceived notion of what it means to be human. The musical also invites the reader to accept and grapple with the parts of one's body one cannot change. In witnessing her tales of rejection and heartbreak, viewers are invited to empathy as they struggle to understand the marginalization Hedwig experiences. The musical invites the audience to examine what being "complete" really means whilst interrogating the norms that demarcate bodily life. The failure of Hedwig to fit into any norm suggests we turn toward unexplored ways of inhabiting the world as we look toward what is "beautiful and new" in how we might understand ourselves.

Funding: This research received no external funding.

Conflicts of Interest: The authors declare no conflicts of interest.

\section{References}

Brakke, David. 2010. The Gnostics: Myth, Ritual, and Diversity in Early Christianity. Cambridge: Harvard University Press.

Broadway.com. 2015. Hedwig and the Angry Inch. Broadway.com. Available online: https://www.broadway.com/ shows/hedwig-and-angry-inch/ (accessed on 15 September 2019).

Butler, Judith. 1990. Gender Trouble: Feminism and the Subversion of Identity. New York: Routledge. 
Butler, Judith. 1993. Bodies That Matter: On the Discursive Limits of Sex. New York: Routledge.

Butler, Judith. 2004. Undoing Gender. New York: Routledge.

Butler, Judith. 2005. Giving an Account of Oneself. Ashland: Fordham University Press.

Butler, Judith. 2006. Afterward. In Bodily Citations: Religion and Judith Butler. Edited by Ellen T. Armour and Susan M. St. Ville. New York: Columbia University Press.

Congregation for Catholic Education. 2019. "Male and Female He Created Them:" Towards a Path of Dialogue on the Question of Gender Theory in Education. Vatican.va. Available online: http://www.vatican.va/roman_curia/congregations/ccatheduc/documents/rc_con_ccatheduc_doc_ 20190202_maschio-e-femmina_en.pdf (accessed on 13 September 2019).

Copeland, Shawn M. 2010. Enfleshing Freedom: Body, Race, and Being. Minneapolis: Fortress Press.

Curran, Charles E. 2005. The Moral Theology of Pope John Paul II. Washington, DC: Georgetown University Press.

Gonzalez, Michelle. 2007. Created in God's Image: An Introduction to Feminist Theological Anthropology. Maryknoll: Orbis Books.

Halberstam, Jack. 2018. Trans*: A Quick and Quirky Account of Gender Variability. Oakland: University of California Press.

Henry, Matthew. 2016. A One-Inch Mound of Flesh: Troubling Queer Identity in Hedwig and the Angry Inch. Journal of American Culture 39: 64-77. [CrossRef]

Jennings, Willie James. 2010. The Christian Imagination: Theology and the Origins of Race. New Haven: Yale University Press.

John Paul II. 1997. The Theology of the Body: Human Love in the Divine Plan. New York: Pauline Books \& Media.

Mitchell, John Cameron. 1998. Hedwig and the Angry Inch. Woodstock: Overlook Press.

Sabsay, Leticia. 2016. Permeable Bodies: Vulnerability, Affective Powers, Hegemony. In Vulnerability in Resistance. Edited by Judith Butler, Zeynep Gambetti and Leticia Sabsay. Durham: Duke University Press.

Salamon, Gayle. 2010. Assuming a Body: Transgender Theory and Rhetorics of Materiality. New York: Columbia University Press.

Salzman, Todd A., and Michael G. Lawler. 2008. The Sexual Person: Toward a Renewed Catholic Anthropology. Washington, DC: Georgetown University Press.

Taylor, Charles. 1991. The Ethics of Authenticity. Cambridge: Harvard University Press.

Tilley, Terrence W. 2010. Faith: What It Is and What It Isn't. Maryknoll: Orbis Books.

Tracy, David. 1981. The Analogical Imagination: Christian Theology and the Culture of Pluralism. New York: Herder \& Herder.

Tracy, David. 1987. Plurality and Ambiguity: Hermeneutics, Religion, Hope. San Francisco: Harper \& Row.

Tracy, David. 1994. Literary Theory and Return of the Forms for Naming and Thinking God in Theology. Journal of Religion 74: 302-19. [CrossRef]

Tracy, David. 2018. The Catholic Imagination: The Example of Michelangelo. New York: Metropolitan Museum of Art. Universal Life Church. 2019. John Cameron Mitchell. Universal Life Church. Available online: https://www. universallifechurchministers.org/john-cameron-mitchell/ (accessed on 15 September 2019).

(C) 2019 by the author. Licensee MDPI, Basel, Switzerland. This article is an open access article distributed under the terms and conditions of the Creative Commons Attribution (CC BY) license (http://creativecommons.org/licenses/by/4.0/). 

MDPI

St. Alban-Anlage 66 4052 Basel

Switzerland

Tel. +41 616837734

Fax +41 613028918

www.mdpi.com

Religions Editorial Office

E-mail: religions@mdpi.com

www.mdpi.com/journal/religions

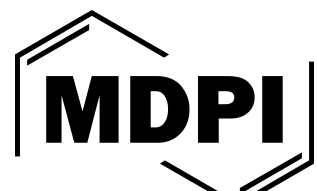



MDPI

St. Alban-Anlage 66

4052 Basel

Switzerland

Tel: +41 616837734

Fax: +41 613028918 